
DEPARTMENT OF THE INTERIOR

UNITED STATES GEOLOGICAL SURVEY

CHARLES \%, WALCOT'T, DHECTOK

DESCRIPTIYE GEOLOGY

OF

\section{NEVADA SOUTH OF THE FORTIETH PARALLEL AND ADJACENT PORTIONS OF CALIFORNIA}

JOSIAH EDWARD SPURR

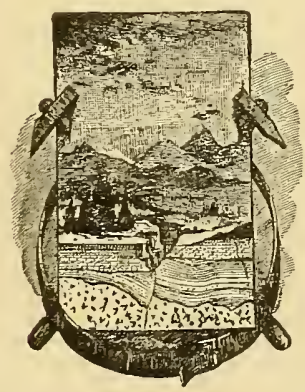

W ISHINGTON

GOVERNIENT PRINTING UFFICE

1903 
028
75
.89
09.208

SEP 3.01999 


\section{CONTENTS.}

Page.

Introduction . .

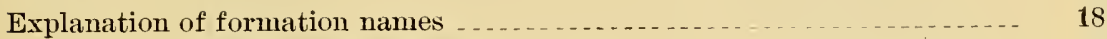

Aubrey limestone and sandstone _..................... 18

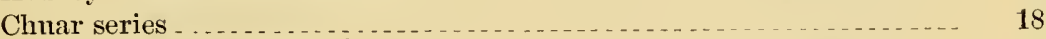

Diamond Peak quartzite . . . . .

Esmeralda formation . . . . . .

Eureka quartzite ..... . . . . . . 19

Grand Canyon group .... . . . . . . 19

Hamburg limestone and shale . . _ . 19

Humboldt series

Koipato formation. . . .

Lone Mountain limestone $\ldots \ldots \ldots \ldots$

Nevada limestone . . . . . . . . . . . . . . . . .

Ogden quartzite . .

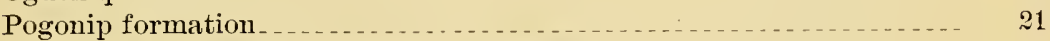

Prospect Mountain limestone and quartzite

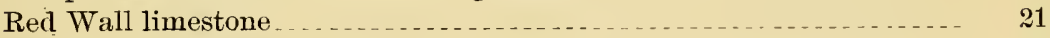

Secret Canyon sliale. . . . . .

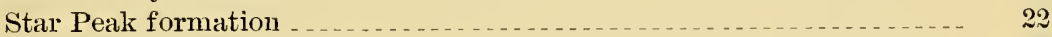

Tonto shale and sandstone _...

Truckee formation . . . . . .

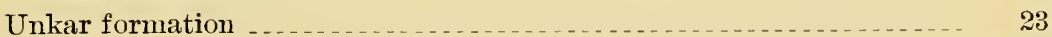

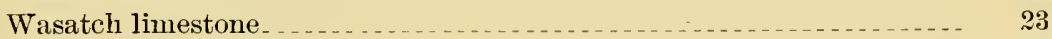

Weber conglomerate

White Pine shale _........ _...

Chapter I. -Ranges of east-central Nevada $\ldots \ldots \ldots \ldots$

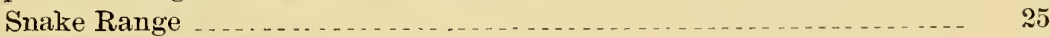

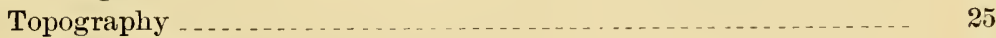

Archean rocks . . ... . . . .

Sedimentary rocks . . . . .

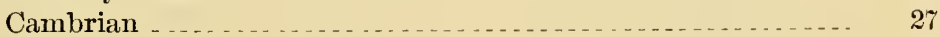

Silurian . . .

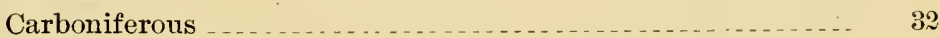

Mesozoic or Tertiary . . .

Pliocene . . . . . . 34

Pleistocene

Igneous rocks $\ldots \ldots \ldots \ldots$

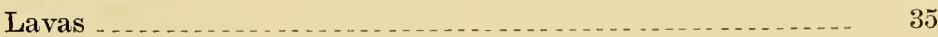

Dike rocks. . . .

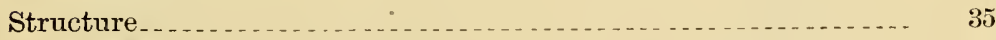

Folds . . .

Faults . . . . .

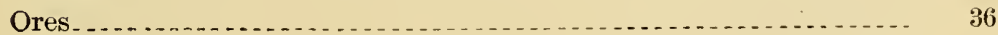


Chapter I.-Ranges of east-central Nevada-Continued.

Page.

Cedar Range and Clover Valley Momntains . . . . . . . . . . . . . . . 36

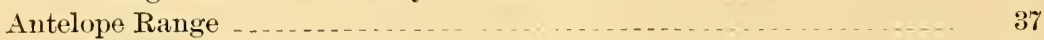

Sedimentary rocks . . . . . . . . . . 37

Igneons rocks _... . . . . .

Structure _. . . . . . . .

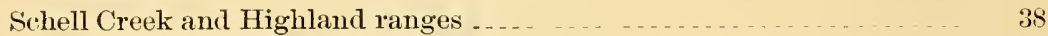

Seclimentary rocks . . . . . _ n

Cambrian _.......

Silurian ......

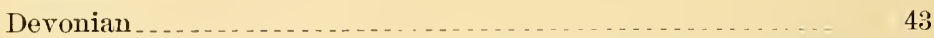

Carboniferons . . . . . .

Igneous rocks ...

Lavas . . . .

Dikes . . . . .

Structure . . .

Folding ....

Fanlting _. . . .

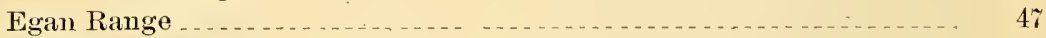

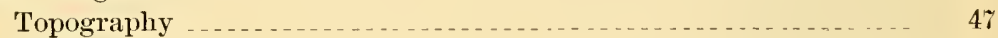

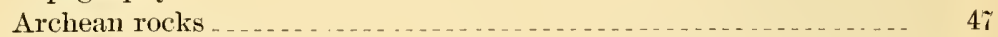

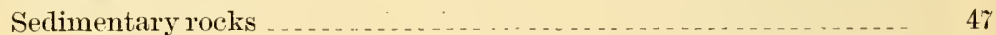

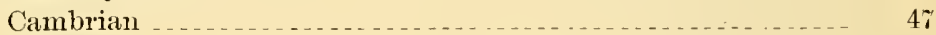

Silurian _. _ .

Devonian _. . . . . . .

Carboniferons ............... 51

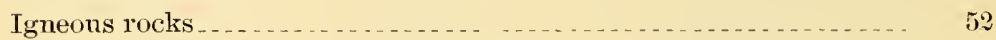

Lavas _... . . . . . . . . .

Dikes . . . . .

Structure _...

Folding _...

Fanlting - .

Ores ... . . .

Long Valley Range...... 54

Topography ............

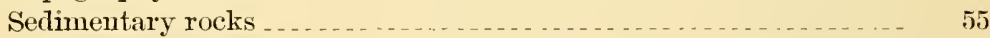

Carboniferous _...

Igneous rocks _...

Lavas . . 56

Structure _._.

Folding ...

Golden Gate Range _.............. 57

Topography …

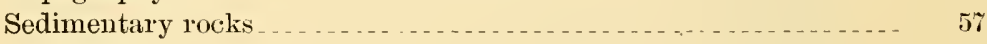

Silurian $\ldots 505$

Devonian _...

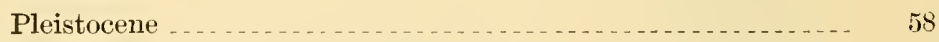

Igneous rocks.... . . . . . . . . . .

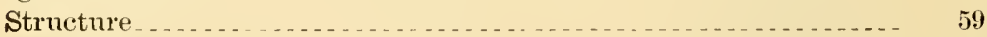

Folding _.

Fanlting _...

Humboldt Range ...

Topography …

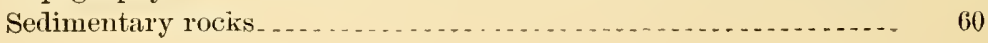


Chapter I.-Ranges of east-central Nevada-Continued.

Humboldt Range-Continned.

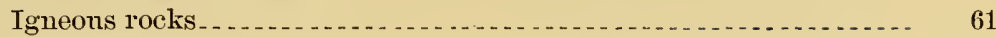

Structure $\ldots \ldots$

Folding - .

Faulting - .

White Pine Range .

Topography $\ldots \ldots \ldots$

Sedimentary rocks

Cambrian _...

Silurian . .

Devonian . .

Carboniferons .

Rhyolite ash . . . . . . . . . .

Igneous rocks .........

Lava $\ldots \ldots$

Granite . . .

Structure . . . .

Folding - .

Fanlting ............. 66

Relation of topography to structure

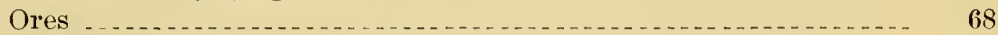

Quimn Canyon and Grant ranges.................... 68

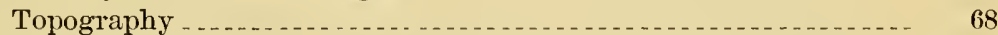

Sedimentary rocks _.

Cambrian . 69

Silurian . .

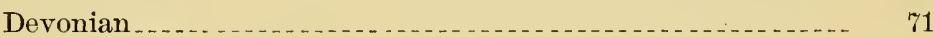

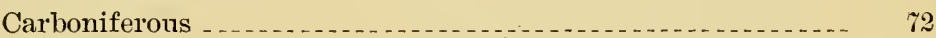

Pliocene

Igneous rocks ...

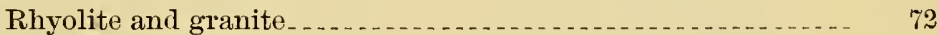

Basaltic volcanics . .

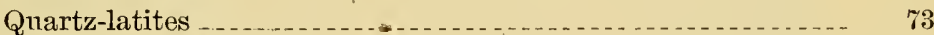

Relative age of lavas ...

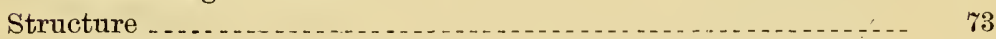

Folding -........... 73

Fanlting ...

Relation of structure to topography _...

Worthington Mountains _...

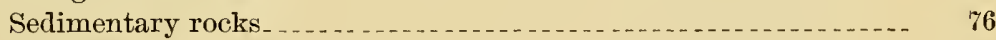

Igneous rocks . . . .

Structure _... . . . . . . .

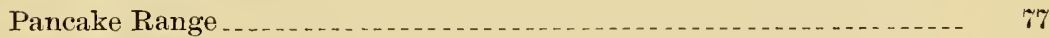

Topography .................. 79

Serlimentary rocks_......... 79

Carboniferous . .

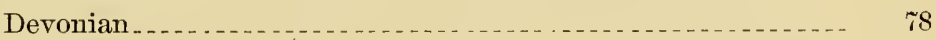

Tertiary .....................

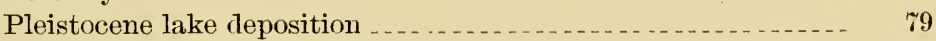

Gulch dumps or alluvial fans _...

Igneous rocks _...........

Structure

Folding _.....

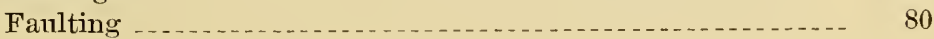


Chapter I.-Ranges of east-central Nevada-Continued. Page.

Pancake Range-Continued.

Coal

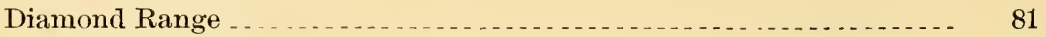

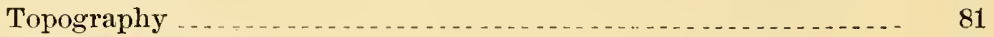

Sedimentary rocks ...

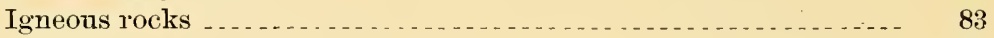

Structure _...

Relation of structure to topography ....

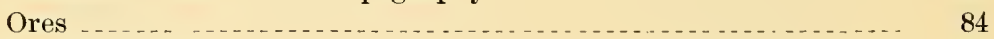

Hot Creek Range ........ 84

Sedimentary rocks

Silurian .............. 85

Tertiary . . . .

Igneons rocks ...

Lavas . . .

Structure $\ldots \ldots$

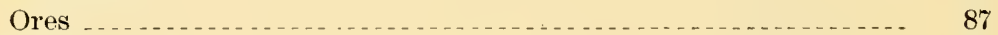

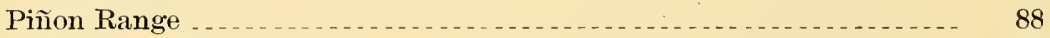

Topography _... 88

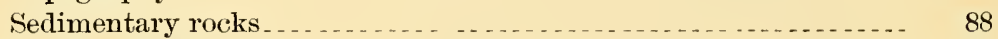

Igneous rocks ..........

Volcanic rocks _...

Structure

Monitor Range ...

Wahweah Range

Toqnima Range ......... 90

Topography - ......... 90

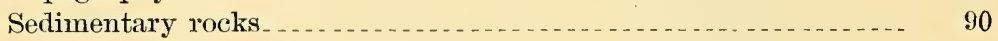

Igneous rocks .

Lavas ... 92

Dike rocks _ _ _

Structure $\ldots \ldots \ldots 2$

Ores.

Toyabe Range .

Topography _... 93

Sedimentary rocks...

Cambrian _...

Silurian _...

Devonian ...

Carboniferons _...

Tertiary _...

Igneous rocks $\ldots$

Granite .............. 95

Rhyolite......

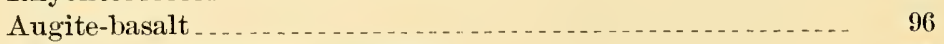

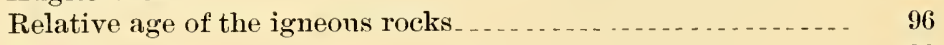

Structure...

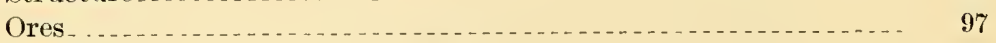

Chapter II.-Ranges of west-central Nevada $\ldots$

Reese River Range ................ 98

Topography .............. 98

Igneons rocks $\ldots$

Age of lavas. 
Chapter II.-Ranges of west-central Nevada-Continued.

Ellsworth Range

Page.

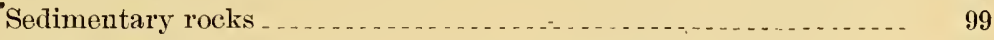

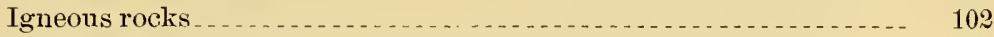

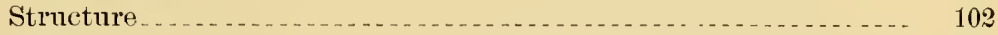

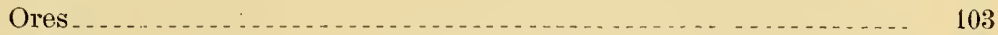

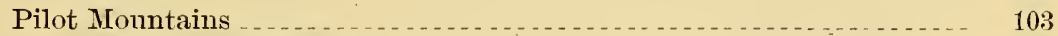

Sedimentary rocks _........ $\ldots \ldots \ldots$

Early Tertiary or Mesozoic series _........................ 103

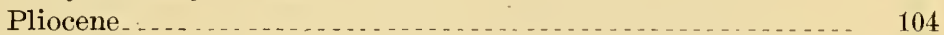

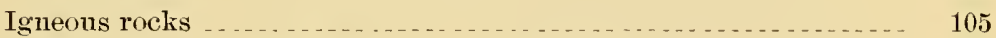

Pleistocene olivine-basalt _. . . . 105

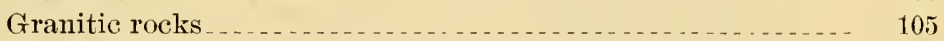

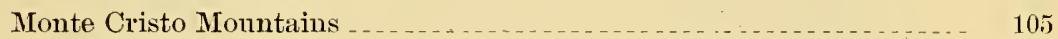

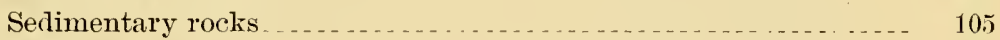

Igneous rocks _. . . $\ldots \ldots \ldots \ldots \ldots$

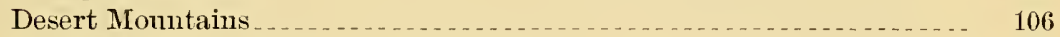

Gabbs Valley and Gabbs Valley Range. . . _.................... 10

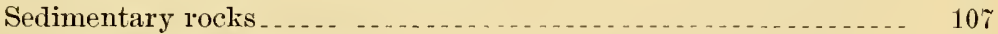

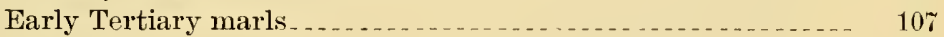

Pleistocene _........... 108

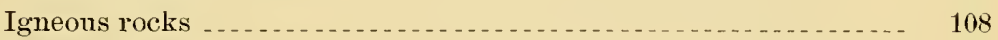

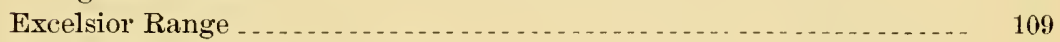

Sedimentary rocks _._.

Limestone series (early Tertiary) _... $\ldots \ldots \ldots$

Sandstone-shale series (early Tertiary or Mesozoic:) _........ 110

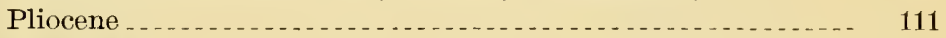

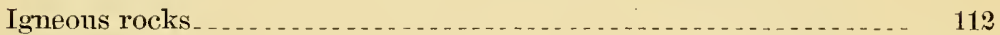

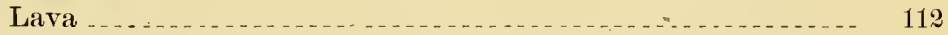

Granitic rocks _...

Structure _...

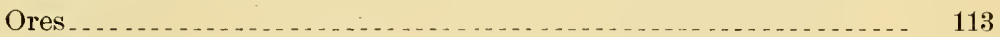

Résumé _. . .

Candelaria Monntains _. . . . . . . . . . 113

Sedimentary rocks _... $\ldots \ldots \ldots \ldots \ldots \ldots \ldots$

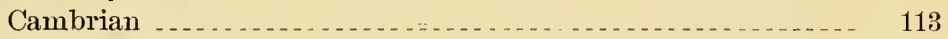

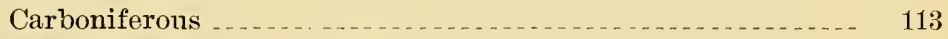

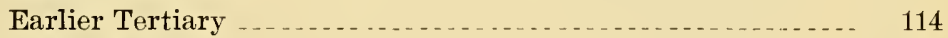

Pliocene beds . . . . . . . 114

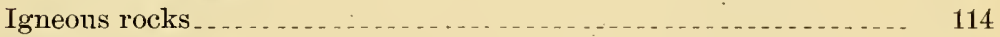

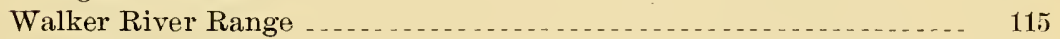

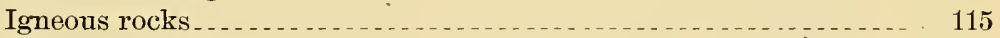

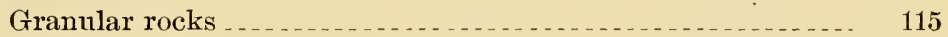

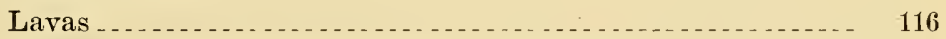

Igneous rocks showing transitions of lexture ............. 116

Sedimentary rocks _... $\ldots \ldots \ldots \ldots \ldots$

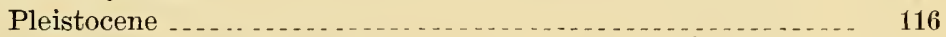

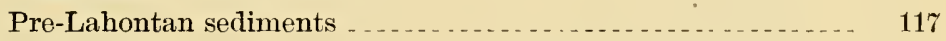

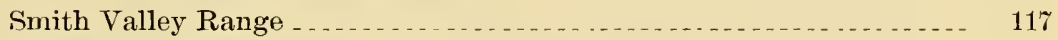

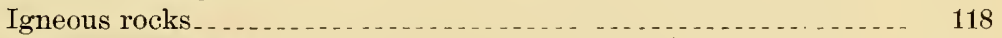

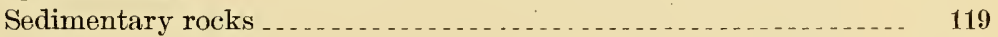

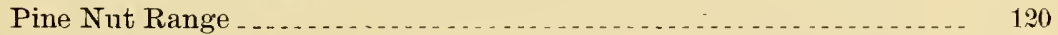

Topography _...

Igneous rocks $\ldots \ldots \ldots$ 
Chapter II - Ranges of west-central Nevada-Continned.

Page.

Pine Nut Range-Continned.

Sedimentary rocks

Triassic limestone

Pliocene deposits . . . . . . . . . . . . 123

Sweetwater Range. . . . . . . . . . .

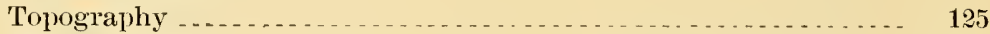

Igneous rocks _. . . 126

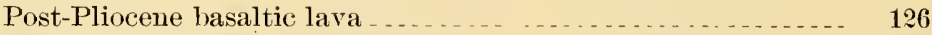

Late rhyolitic lava. . . . . . . . . . . . . . . . . . . . . . . 126

Late andesite and latite . . . . . . . . . . . . . . . . . 126

Earlier andesites . . . . . . . . . . . . .

Earlier rhyolite ... . . . . . . . . . . . . . . . . . . . . . . . 127

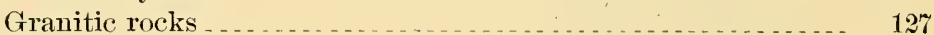

Sedimentary rocks _.......

Pliocene deposits . $\ldots \ldots \ldots \ldots$

Résumé _. . . . . . . . .

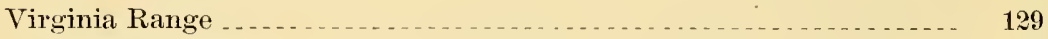

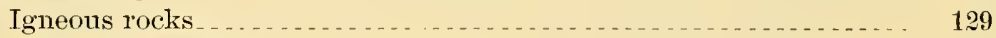

Sedimentary rocks .... _ . . . . . 130

Ancient limestones. ... . . . . . . . . . . . . . . . . . . . 130

Chapter III.-Ranges of sonthern Nevada ... . . . . . . . . . . . . . . . . 131

Virgin Range ................... 131

Sedimentary rocks . . . . . . . . . . . . . . . . . . 131

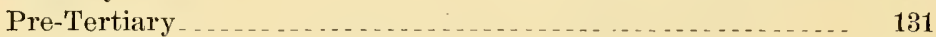

Pliocene ... . . . . . . . . . . . . . . . 131

Igneous rocks . . . . . . .

Structure ... $\ldots \ldots \ldots \ldots \ldots \ldots$

Colorado Canyon . . . . . 133

Mormon Range . . . . . . . 134

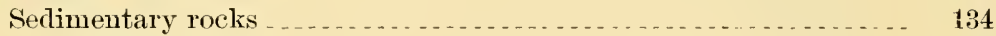

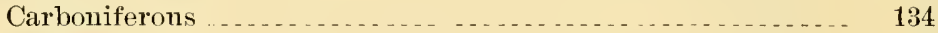

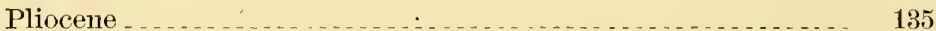

Igneouts rocks . . . . . . . . . . . . . . . . . .

Structure... . . . . . . . . . . . . . 135

Mnddy Range . . . . . . . . . . . . . . . . . . . . . . . . . . . . . . . . . 136

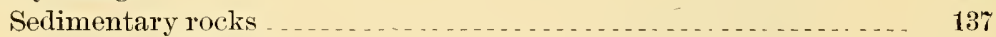

Carboniferons . . . . . . . . . . . . . 137

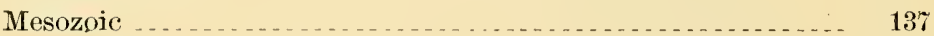

Tertiary _...

Igneous rocks . . . .

Structure . . . . . . . . . . . . . . . . . . . . . . . . . . . . . . . . . 198

Colorado Range . . . 138

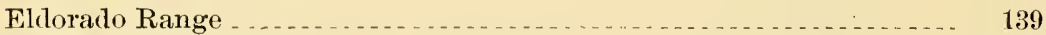

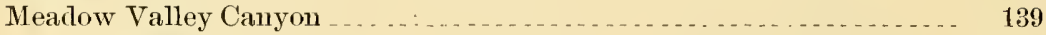

Topography ...

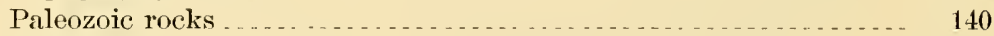

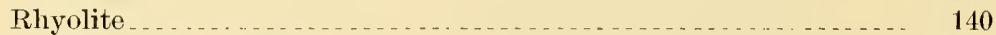

Rhyolite-sandstone series _. . . . . . . . . . . . . . . . . . . . . . . 140

Andesite-latite series . . . . . . . . . . . . . . . . . . . . . . . . . . . 141

Reddish dacites and rhyolites and associated sediments......... 142

Pliocene beds ... . . . . . . . . . . . . . . . . . . . . . . . . . . . . . 143

Pliocene rhyolites . . . . . $\ldots \ldots \ldots \ldots$

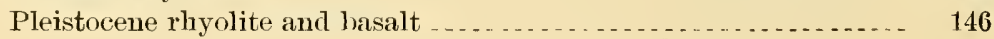


Chapter III.-Ranges of southern Nevada-Continned.

Page.

Meadow Valley Canyon-Continued.

Pleistocene gravels

Sequence of events

Meadow Valley Range

Sedimentary rocks

Cambrian

Carboniferous

Pliocene.

Igneous rocks

Structure.

Pahroc Range

Igneous rocks

Sedimentary rocks

Structure.

Hiko Range -

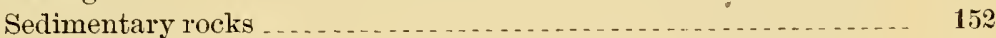

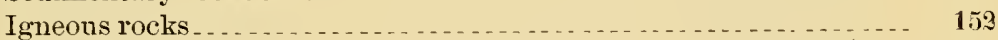

Structure ... . . . . . . . . . . . .

Pahranagat Range ......

Sedimentary rocks .... . . . . .

Igneons rocks. ... . . . . . . . . . . . . .

Structure

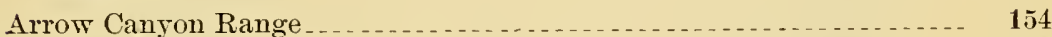

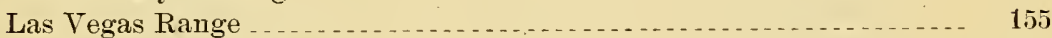

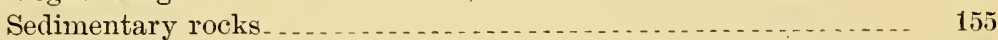

Cambrian $\ldots \ldots \ldots \ldots \ldots$

Silurian . . . . .

Devonian ... . . .

Carboniferons _...

Pleistocene :

Structure $\ldots \ldots \ldots \ldots \ldots$

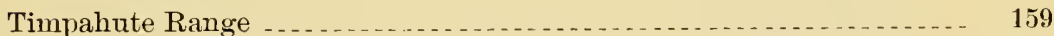

Sedimentary rocks $\ldots \ldots \ldots \ldots$

Igneous rocks _. . . . . . . .

Structure _. . . . . 160

Ore deposits . . . 160

Desert Range $\ldots \ldots$. . . 160

Sedimentary rocks .......

Silurian ....

Devonian . . . . .

Structure ..... . . . 161

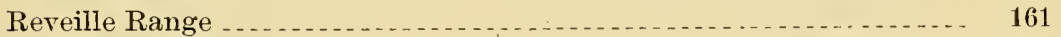

Topography .........

Sedimentary rocks _... . . . .

Tertiary $\ldots \ldots 3$

Igneons rocks . . .

Relative age of igneous rocks ...

Ore deposits .

Belted Range

Sedimentary rocks .............

Cambrian .......... 164

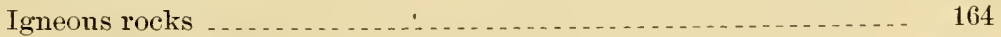

Volcanic rocks ...

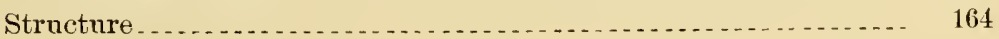


Chapter III.-Ranges of southern Nevada-Continued. Page.

Spring Mountain Range . . . . . . . . . . . . . . 164

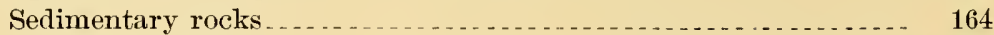

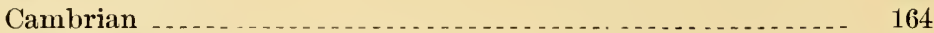

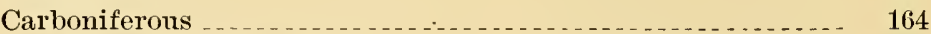

Lower Carboniferons _

Carboniferous red beds _... $\ldots \ldots \ldots \ldots$

Upper Carboniferous limestone . . . _ _............. 170

Correlation with Grand Canyon section _............ 1 . 1 2

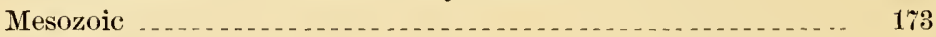

Igneous rocks.

Structure

Ore deposits .

Area south of Spring Mountain _.

Kawich Range ........................ 181

Topography .

Sedimentary rocks ......

Tertiary . . . 181

Igneous rocks ...

Ralston Desert. . .

Igneons rocks . . . . .

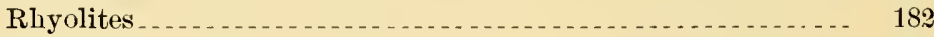

Basalt ... . .

Sedimentary rocks _...

Tertiary . . . . .

Pleistocene .....

Lone Mountain ..... . . . 183

Igneous rocks . . . . . . 184

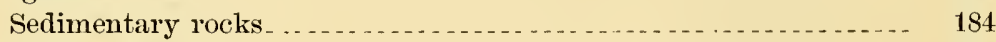

Silver Peak Range . ... . . . . . . . . . .

Sedimentary rocks _.................. 184

Cambrian _...

Silurian _...

Early Tertiary

Pliocene . .

Igneous rocks $\ldots \ldots 6$

Granites . . . . . . . . . . . 186

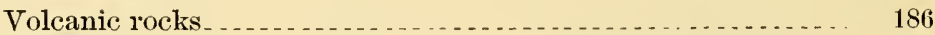

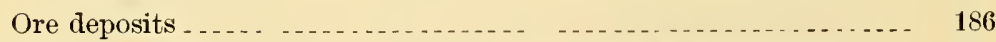

Chapter IV.—Great Basin ranges of California, north of Mohave Desert... . 187

Grapevine and Funeral ranges . . .

Sedimentary rocks . . . . .

Silurian _...

Devonian . . . . . .

Tertiary _...

Pleistocene ...

Igneons rocks ........

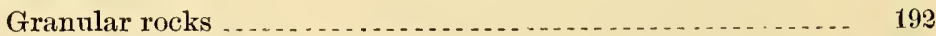

Olivine-basalt at Furnace Creek ........................ 192

Andesite at Furnace Creek . . . . . . . . . . . . . . . . . . . . . 192

Volcanics north of Furnace Creek . . _ . _.............. 192

Structure $\ldots \ldots \ldots 3$

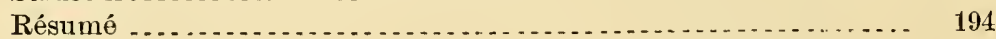


Chapter IV.-Great Basin ranges of California, etc.-Continued.

Amargosa Valley

Page.

Metamorphic rocks

195

Sedimentary rocks

195

Tertiary

195

195

Structure

195

Kingston Range .

Sedimentary rocks .

Cambrian

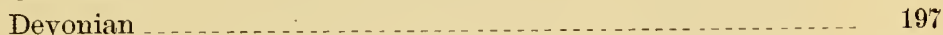

Mesozoic _... . . . . .

Tertiary

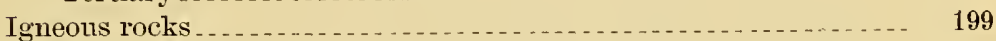

Structure _.............

Opal or Clarks Peak Mountains ............................. 200

Ore deposits . . . . . . . .

Panamint Range . . . . . .

Sedimentary rocks .......... 201

Cambrian . . . .

Silurian and Carboniferous.

Early Tertiary .............. 202

Late Tertiary ........ 202

Pleistocene

Igneous rocks

Granite

Volcanic rocks _...

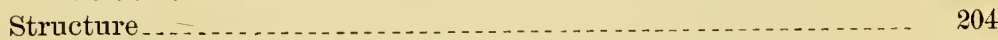

Ore deposits .................. 205

Leach Point and Burnt Rock Mountains _... _...

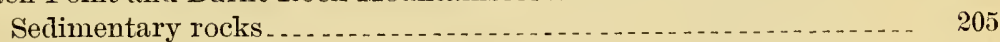

Limestone

Eocene

Igneous rocks . .

Granite .............. 206

Volcanic rocks........... 206

Structure

White Mountain Range.

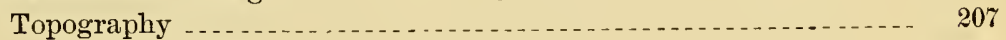

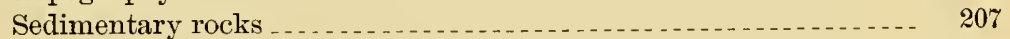

Cambrian _...

Silurian _... 208

Carboniferons _... 208

Triassic _... 208

Pliocene . . . .

Igneous rocks .

Granitic rocks _...

Volcanic rocks.

Ore deposits . .

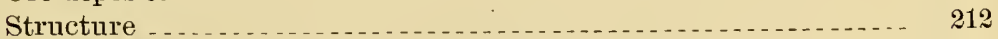

Darwin or Argus Range... . . 212

Sedimentary rocks

Igneous rocks ............

Granite

Volcanic rocks $\ldots \ldots \ldots 212$

Ore deposits $\ldots \ldots$ 
Chapter IV.-Great Basin ranges of California, etc.-Continued.

Slate Range

Page.

Sedimentary rocks ......

Paleozoic

Tertiary _ . 213

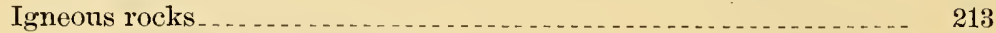

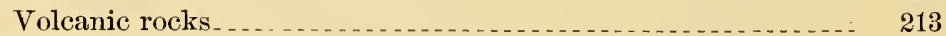

Coso Range . . . . . . . . . . . . . . . . . . . . . . 214

Igneons rocks . . . . .

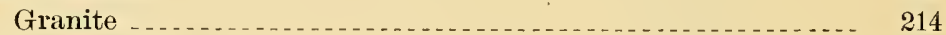

Volcanic rocks

EI Paso Range . . . . . 214

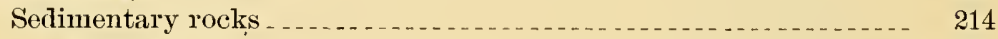

Early Tertiaries .

Igneous rocks ........

Granite - . . . 215

Volcanic rocks............

Structure .... . . 216

Ore deposits . . . . 216

Hills from Randsburg east to Pilot Knob. _...

Sedimentary rocks . . .

Arkoses . . .

Igneous rocks .........

Ore deposits . .

Sierra Nevada

Sedimentary rocks . .

Cambrian . . . . . 218

Carboniferous ..... 219

Triassic . . . 219

Jurassic . . . . . .

Igneons rocks. . . . . .

Structure $\ldots \ldots \ldots \ldots$

Index 


\section{ILLLITSTRTIONS.}

Plate I. Geological recommaissance map of Nevada south of the fortieth parallel, with adjacent California .................. In pocket

II. Map showing position of geological reconnaissance map and chief data used in its compilation . ...... . . . . . . . . . . . . . . . . . ...

III. A, Jeff Davis or Wheeler Peak. Snake Range, from Robinson's rancli; $B$, North end of Schell Creek Range, from Antelope

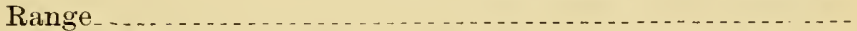

IV. A, Snake Mountains north of Robinson's ranch; $B$, Antelope

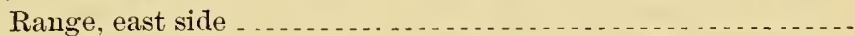

V. A. East face of low mountain range west of Egan Range at Ely; $B$, Tertiary volcanic cone, Pancake Range, east side of Hot Creek

VI. A, Rhyolite walls of Meadow Valley Canyon at Carson's ranch; $B$, Pliocene conglonerate in Meadow Valley Canyon at Kane Spring

VII. A, North scarp of Stonewall Mountain, Ralston Desert; $B$, Pyramid Peak, Grapevine Range, from the head of Furnace Creek . -

VIII. Sketch structure section of Grapevine Range at Furnace Creek: $A$, Sketch cross section of the southern end of the Grapevine Range, at Furnace Creek; $B$, Sketch longitudinal section from the southern end of the Grapevine Range southward across Furnace Creek

Fig. 1. Sketch section 5 miles north of Hamilton across White Pine Range to the eastern edge of Long Valley Range . . . . . . . . . . . . . . . .

2. Sketch section through White Pine Range at Hamilton at the junction of White Pine and Long Valley ranges

3. Generalized section on a line drawn a little north of east across Quinn Canyon and Grant ranges; at the north end of Quinn Canyon Range, but south of the fault line . . . . . . . . . . . . . . . .

4. Sketch section of east front of Grant Range, taken 5 miles north of locality of fig. 3

5. Generalized sketch section of north end of Quinn Canyon Mountains .

6. Generalized sketch cross section of Pancake Range at north side of pass at Twin Springs

7. Generalized sketch section across Hot Creek Range at Hot Creek ..

8. Section of Eldorado Canyon, Pinenut Range ...................

9. Sketch section of wall of arroyo in bottom of Eldorado Canyon, Pinenut Range

10. Generalized cross section of northern end of Mormon Range. .....

11. Cross section of Muddy Range, after R. B. Rowe . . . . . . . . . . 
Fig. 12. Sketch section of east wall of Meadow Valley Canyon just sonth of Carson's ranch.

Page.

13. Sketch section of west wall of Meadow Valley Canyon at same locality as fig. 12

14. Sketch of east side of Meadow Valley Canyon near locality of figures 12 and 13

15. Sketch section of south wall of Hackberry Canyon near junction with Meadow Valley Canyon

16. Sketch section of north wall of Meadow Valley Canyon 3 miles southwest of month of Hackberry Canyon

17. Sketch section on east wall of Meadow Valley Canyon from Kane Spring to Grapevine Spring

18. Sketch section of west wall of Meadow Valley Canyon at Grapevine Spring

19. Sketch section of wall of Hackberry Canyon at Hackberry Spring-

20. Sketch section of sonthern end of Meadow Valley Range extended through the New Mountain Ridge.

21. Generalized sketch cross section of Reveille Range near Reveille

22. Generalized sketch sectious across Spring Mountain Range

23. Section showing great fault at Olcott Peak, after R. B. Rowe ...

24. Cross section of southern end of Spring Mountain Range (east and west), showing great fault several miles north of the point represented in fig. 23

25. Cross section of Bird Spring Mountains (sonthern spur of Spring Mountain Range), after R. B. Rowe 

U. S. GEOLOGICAL SURVEY

BULLETIN NO. 208 PL. ॥

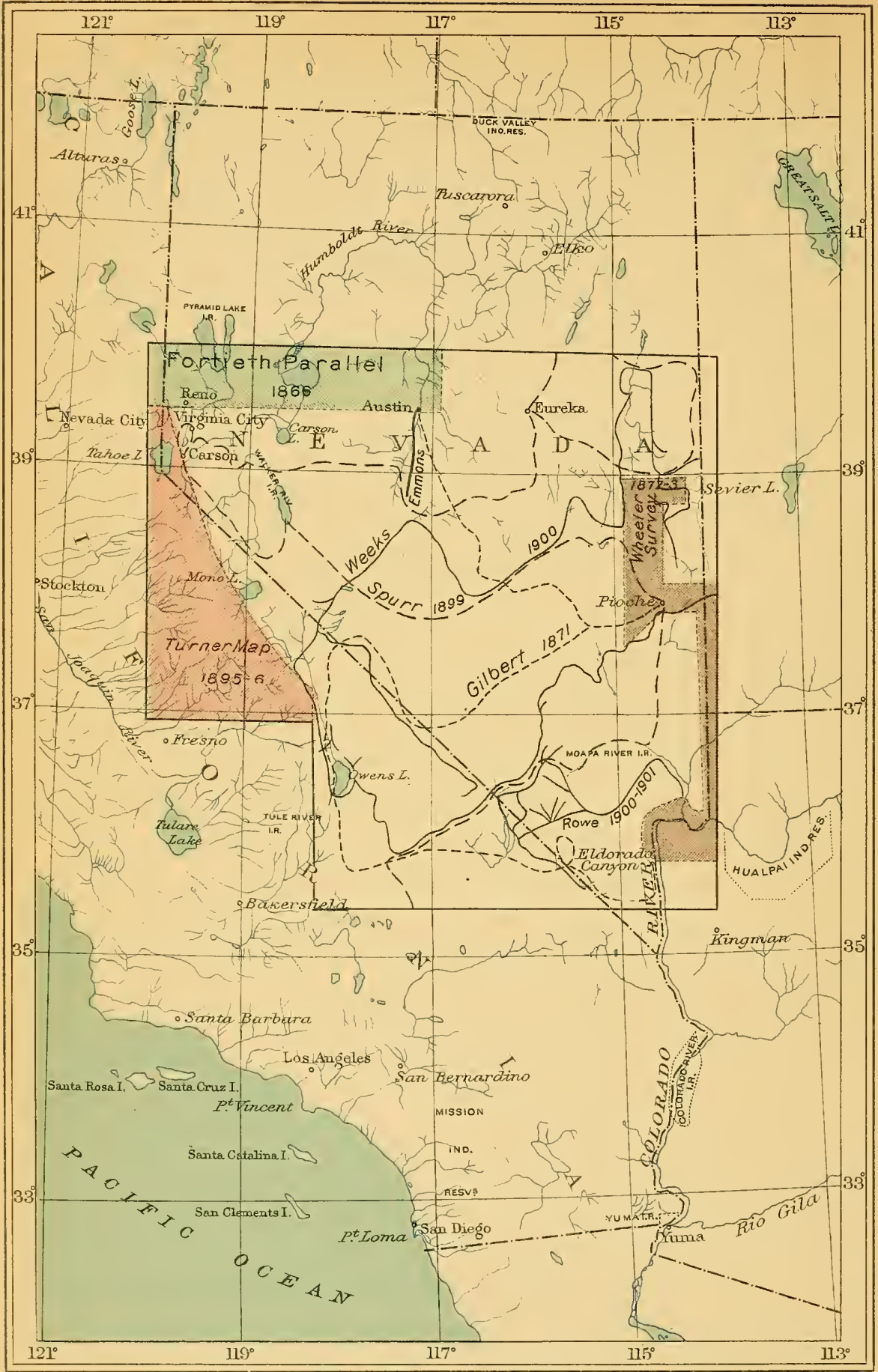

MAP SHOWING POSITION OF

GEOLOGTCAL RECONNAISSANCE MAP AND CHIEF DATA USED IN ITS COMTILATION 


\title{
DESCRIPTIVE GEOLOGY OF NEVADA SOUTH OF THE FORTIETH PARALLEL AND ADJACENT PORTIONS OF CALIFORNIA.
}

\author{
By JOSIAH Edward SPUrR.
}

\section{N TRODUCTION.}

The field work upon which the present bulletin is based, so far as the writer's labors are concerned, was done in the summer and fall of 1899. After visiting the Wasatch Range to study briefly the Wasatch Paleozoic section, as determined by the Fortieth Parallel Survey, the writer proceeded to Eureka, in Nevada, and there spent two weeks in studying that section, the best and most complete yet discovered in the far West. Feeling finally ready for untried ground, the expedition, consisting, besides the writer, of a teamster, a cook, and an assistant, left Eureka and proceeded sontheastward to Hamilton, and then to Ely. From Ely the route ran to Osceola in the Snake Creek Range, thence across that range and northward up Snake Valley to Pleasant Valley, where a westward course was again taken. Schellbourne and Cherry Creek, the latter in the Egan Range, were next visited, and thence the way led northwestward to Ruby Lake, and so back to Eureka. During part of this journey some of the region which had been mapped by the Fortieth Parallel Survey was traversed, this route being purposely chosen so as to permit study in the field of the application of the Fortieth Parallel geologic section. After replenishing supplies at Eureka the expedition took the road sonthward to Hot Creek, and thence proceeded westward to Belmont. The country to Carson was then traversed, the more or less inactive mining camps of Ione, Ellsworth, and Downieville and the Indian reservation at Walker Lake being passed. At Carson a short time was spent, and the famous Comstock lode and the sonthern end of the Virginia Range were visited. From Carson the route was southwestward past Wellington, Hawthorne, Sodaville, Columbus, and Silver Peak, to Lida. From Lida the course was again toward the east, and the State of Nevada was crossed again by way of the Ralston Desert, Twin Springs, and White River, to Pioche. From Pioche, Meadow Valley Canyon was followed southward to the Indian reservation at Moapa or West Point, not far from the Colorado, then, a turn to the west being made, the 
State was crossed a third time, by way of Indian Springs and Pahrump Talley, into California. Funeral Range was crossed and Death Valley entered at Furnace Creek. From here the expedition went sonthward, and, crossing the Panamint Range at: Windy Gap, proceeded by way of Granite Wells to Johannesburg. From Johannesburg the party proceeded across the Mohave Desert, crossing the Santa Fe Railroad at Hinckley. Finally San Bernardino was reached, which was the end of the journey. This trip lasted about five months, and comprised over 2,000 miles of actual travel.

The primary object of the expedition was to make the roughest kind of a general geologic map, such as might fill up the great gaps in the map of the western United States. It being the intention of the Survey to publish a general geologic map of the United States on a scale of about 40 miles to the inch, no great amount of detail was advisable or possible. On account, also, of the rough and inaccurate manner in which much of the region of the western United States has been already mapped, it was not advisable to modertake to do any work of higher grade.

In order to accomplish the style of mapping desired with as much economy of time and labor as possible, the writer determined to avoid any duplication between his route and those already traveled by geologists, and carefully planned his journeys with that end in view. On the north the area which he undertook to investigate was bounded by the geologie maps of the Fortieth Parallel Survey (atlas maps 4 and 5); on the east it was bounded by the geologic maps of the Wheeler survey; and on the west chiefly by a reconnaissance map of the Sierra Nevada published by Mr. II. IV. Turner in the Seventeenth Annual Report of the United States Geological Survey, Part I; on the south there was no definite boundary.

Within the area to be mapped, about the only important journey that had been made by a geologist had been accomplished by Mr. Gilbert in 1871, while with the Wheeler Topographic Survey. His ronte, with the other boundaries already mentioned, is shown on Pl. II. The writer was able to so plan his route with reference to the work of $\mathrm{Mr}$. Gilbert and to the maps which bounded the area that hardly any point in the region examined can be found which is more than 30 miles from a point of observation. This in any country would probably be sufficient for a reconnaissance map on a scale of 40 miles to the inch, but in the Great Basin region of Nevada and California the conditions are especially favorable, so that a map can be made having far more value than in ordinary regions. The clear air, the lack of vegetation, and the general continuity of formations parallel with the north-south rauges all combine to make a reconnaissance more satisfactory than usual. The attitude of strata or a conspicuous formation may often be followed 15 or 20 miles along the front of a mountain, by the aid of a field glass, from a single point. 
The foregoing explanation indicates clearly enough the character of the map and the weight which should be placed upon it. The data along the lines of reconnaissance, often obtained on forced marches of $20 \mathrm{or}^{3} 30$ miles a day, are oftentimes meager and unsatisfactory. Between the lines of actual travel the data are still less reliable, and a great deal of the mapping has been done simply from inference. Thus it is probable that anyone examining closely the detail of the map will find it nearly all inaccurate, while one looking for the main principles will recognize the general correctness of the mapping and the value of the map as a pioneer.

The inaccuracy of the map is mavoidably heightened by the lack of a suitable topographic base. The present base has been prepared in a very rough and unsatisfactory way, chiefly from the Wheeler and other early surveys. It is a source of regret to the author of the bulletin that so rough a topographic map must be presented as the vehicle for his geologic information.

Within the text of the bulletin an effort has been made to give clearly the known facts concerning the geology, whether obtained by the writer or previously. Full eredit is given to previous work, although it can not always be given in the map compiled from this information. The chief sources, however, are shown on PI. II. ${ }^{a}$

The writer has judged it most advisable to confine the text to descriptive matter. General results, especially those involving application of theory, have been withheld or published separately. Among these general results the author has published two papers on volcanism in the Journal of Geology, entitled The Succession and Relation of Lavas of the Great Basin Region (October-November, 1900), and Transitions of Texture in certain Tertiary Igneous Rocks of the Great Basin. A petrographic paper on Quartz-muscovite Rock from Belmont, Nev., has been published in the American Journal of Science (November, 1900). A paper on the Origin and Structure of the Basin Ranges was read before the Geological Society of America at Albany, December, 1900.

\footnotetext{
a After the above was written, and while the bulletin was in galley proof, new information was received as a result of the studies of Messr's. Weeks and Rowe, of the U S. Geological Survey. The studies of Mr. Weeks were made in 1900; those of Mr. Rowe in 1900 and 1901. The results of these have been incorporated in the bulletin.
}

Bull. 208-03-2 


\section{EXPLANATION OF FORMATION NAMES.}

The following is a brief explanation of formation names used in this work. Names are arranged alphabetically.

Aubrey limestone and sandstone.-These names were applied by Messrs. Gilbert and Marvine in 1871 to formations in the Colorado Canyon region. The limestone lies above the sandstone and has a thickness of 820 feet on Kanab Creek. At a few points in the topmost layer were foumd a group of shells suggesting the Permo-Carboniferous of the Mississippi Talley, indicating that the great Paleozoic lithologic change at this horizon marks the absolute elose of the Carboniferons age. Lithologically the limestone is characterized by a great abundance of chert, which toward the top sometimes constitutes half the mass. Near the middle it is in some places interrupted by a belt of shale with gypsum.

The underlying Aubrey sandstone series has a thickness in the Aubrey cliffs and along the Grand Canyon of about 1,000 feet. In every exposure a portion of this body is massive and cross bedded and another portion soft and gypsiferous, but the order of these parts is not constant. The sandstones contain no fossils, but an interealated limestone below the middle of the series at Canyon Creek bears faniliar Coal Measures shells."

Chuar series. This name was introduced by Mr. C. D. Walcott in 1883 for a part of the Lower Cambrian of the Grand Canyon region. Mr. Walcott divided the Grand Cauyon group of Major Powell into a lower and an upper division, the Grand Canyon and the Chuar. In 1886 the reference to the Lower Cambrian was changed to pre-Cambrian. In 1890 these strata were referred to the Algonkian system. In 1894 Mr. Walcott again elassified the Algonkian, dividing the Grand Canyon series of this system into the upper (Chuar) series and the lower (Unkar) series. The Chuar is separated by an unconformity from the overlying Cambrian (Tonto series). ${ }^{b}$

Diamond Peak quartzite. - This name was given by Mr. Hague to the lowest lithologic member of the Carboniferous at Eureka, Nev. At this place the Diamond Peak quartzite consists of 3,000 feet of massive gray and brown quartzites, with brown and green shales at the summit. It underlies 3,800 feet of heary bedded, dark-blue and gray, 
Lower Coal Measures limestone, which contains intercalated beds of ehert and argillaceous beds near the base. The Diamond Peak quartzite is not a persistent lithologie terrane, and is not recognizable with confidence at any great distance from the Eureka section.

Esmeralda formation. - This name was applied by Mr. II. W. Tnrner $^{a}$ to Tertiary formations in the Silver Peak Range, in the western part of Nerada. These deposits consist of sandstones, shales, volcanic tuffs, breccias, conglomerates, and great thicknesses of lacustrine marls. Coal beds and plant remains occur; also fossil shells and fish bones. From the evidence afforded by these fossils, the age of the beds was broadly determined as late Eocene or early Miocene.

Eureka quartzite.-This name was applied by Mr. Hague to the middle of the three divisions of the Silurian in the Eureka district. This division here consists of 500 feet of eompact vitreous quartzite, white or blue in color, and passing into rock of reddish tints near the base, with indistinct bedding. It overlies the Pogonip limestone, and is separated from the overlying Silurian Lone Mountain limestone by an unconformity. The Eureka quartzite appears to be one of the most persistent lithologic terranes of the Nevada Paleozoic. It has been recognized over a wide area.

Grand Canyon group.-The name Grand Canyon group was given by Maj. J. W. Powell to the strata in the Grand Canyon region beneath the Tonto sandstone and above the Grand Canyon schists. The latter were referred tentatively to the Eozoic, and the 10,000 feet of the Grand Canyon group to the Silnrian. In 1883 Mr. C. D. Walcott referred Major Powell's Grand Canyon group to the Lower Cambrian and separated it into an upper and a lower division, the Grand Canyon and the Chuar. In 1886 these rocks were referred by $\mathrm{Mr}$. Walcott to the pre-Cambrian, and in 1890 to the Algonkian. In $1894 \mathrm{Mr}$. Walcott subdivided the Grand Canyon group of the Algonkian into the Chuar and the Unkar series. The Grand Canyon gronp is separated. by an unconformity from the overlying Cambrian (Tonto sandstone), and by a great unconformity from the underlying Vishnu series of schists.

Hamburg limestone and shale.-The Hamburg limestone and shale are the uppermost divisions of the Cambrian as defined by Mr. Iague in the Eureka distriet, Nevada. The Hamburg shale lies at the very top and consists of 350 feet of yellow argillaceous shale containing layers of chert nodules, especially near the top. The underlying Hamburg limestone consists of 1,200 feet of dark-gray granular limestone, with only slight traces of bedding. The Hamburg shale is characterized by well-developed Upper Cambrian fauna. ${ }^{b}$ 
Humboldt series.-This name was applied by King ${ }^{a}$ to a series of loose, friable Tertiary rocks, earrying very recent fresh-water mollusks. This series is found at intervals all over the northern portion of the Great Basin region, from the Sierra Nevada into Utah. Mr. King regarded all these beds, which from their fossils were referred to the late Pliocene, as lake deposits and as representing the sediment of a single lake ont of which the numerous lofty mountain masses rose in a complicated system of islands.

Koipato formation.- This name was applied by Mr. King ${ }^{b}$ to one of the two chief divisions of the Triassie in western Nevada. He describes the Koipato as made up of siliceous and argillaceous beds, whose chemical peculiarity is the almost total absence of soda and lime and the high pereentage of alumina and potash. This series has an observable thickness of about 6,000 feet, with an unknown quantity to be added for the unseen beds at the bottom. The Koipato is overlain by the Triassic Star Peak series.

Lone Mountain limestone. - This name was given by Mr. Hague to the uppermost division of the Silurian in the Eureka district. It consists of 1,800 feet of strata. At the base are black gritty beds passing into light-gray siliceous rocks with all traces of bedding. ohliterated. There are Trenton fossils at the base and Halysites in the upper portion. The formation is separated from the underlying Silurian Eureka quartzite by an unconformity, and is overlain conformably by the Devonian Nevada limestone.

Nevada limestone.-The Nevada limestone, as defined by Mr. Hague, ${ }^{c}$ is the lower member of the Devonian series at Eureka. It consists of 6,000 feet of limestone. The lower horizons are indistinctly bedded, with saccharoidal texture and gray color, passing up into distinctly bedded strata, reddish brown and gray in color, frequently finely striped, producing a variegated appearance. The upper horizons are massive, well bedded, bluish black in color, and highly fossiliferous. The Nevada limestone overlies the Silurian Lone Monntain limestone at Eureka and is overlain by the Devonian White Pine shale.

Ogden quartzite. - This term was applied by King ${ }^{d}$ to a sheet of siliceous sediment, in general compacted into a quartzite. Mr. King stated that this formation had a remarkable evenness over all the Paleozoic area west of and inchuding the Wasatch. In its typical locality, Ogden Canyon, Wasatch Range, it was stated to be 1,200 or 1,400 feet thick; at Cottonwood Canyon 1,000 feet, and in middle Nevada from 800 to 900 feet. In Ogden Canyon it is bounded at the top and bottom by thin beds of greenish-gray argillites; and

a U. S. Geol. Expl Fortieth Par., Vol. I, p. 434.

$b$ Ibid., p. 346.

$c$ Third Ann. Rept. U. S. Geol. Survey, p. 255.

a Op. cit., p. 234. 
about the middle of the quartzite is a thin bed of white, slightly siliceous marble. No fossils were found in this formation, but it was referred to the Devonian, since it was found to overlie the Pogonip limestone, which contains Lower Helderberg fossils, and is overlain by the Wasatch limestone, whose basal beds contain Upper Helderberg forms.

Pogonip formation.-King ${ }^{a}$ described the Pogonip limestone in middle Nevada, in the regions of White Pine, Enreka, Pinyon, and Roberts Peak ranges, as being Cambrian in the lower half and containing Silurian fossils in its upper 2,000 feet. In the Eureka section, the term Pogonip was limited by Mr. Hague ${ }^{b}$ to the Silurian portion of the series, which consists of 2,700 feet of interstratified limestone and argillites, with arenaceous beds at the base. These rocks pass into pure, fine-grained limestone of a bluish-gray color, distinctly bedded. They are highly fossiliferous. The Pogonip limestone is the lowest member of the Silurian of the Eureka section. "It overlies the topmost member of the Cambrian, the Hamburg shale, conformably, and is conformably overlain by the Silurian Eureka quartzite.

Prospect Mountain limestone and quartaite.-These names were given by Mr. Hague ${ }^{b}$ to the two lowest divisions of the Cambrian section at Eureka, Nev. The Prospect Mountain quartzite is the lowest and consists of 1,500 feet of bedded brownish-white quartzites, weathering dark brown but whiter near the summit. The quartzites contain intercalated thin layers of arenaceous shales, and are ferruginous near the base.

The quartzite is overlain by the Prospect Mountain limestone, which eonsists of 3,050 feet of gray, compact limestone of rather light shade, traversed by thin seams of calcite. It has rery imperfect bedding planes. The upper portion of the Prospect Mountain quartzites is characterized by the Olenellus or Lower Cambrian fauna, and the Prospect Mountain limestone by the Middle Cambrian fanna of the Rocky Mountain section.

Red Wall limestone.-This name was applied by Messis. Gilbert and Marvine ${ }^{c}$ to a heavy Carboniferous limestone in the Grand Canyon region. This limestone has a gray color on fresh fracture, but shows a red rust on weather-stained cliffs. It is generally heavy bedded to massive. At the top sandstone alternates with limestone for from 200 to 500 feet. Through its lower half the limestone is interrupted by occasional shaly bands. The average total thickness is 2,500 feet. Fossils are abundant near the top but rare in the lower part. The upper portion contains Coal Measures fossils. The lowest

a U. S. Geol. Expl. Fortieth Par., Vol. I, p. 232.

$b$ Third Ann. Rept. U. S. Geol. Survey, p. 255.

$c$ U. S. Geog. Surv. W. One Hundredth Mer., Vol. III, p. 178. 
fossils were obtained just below the middle of the series, and were doubtfully referred to the Lower Carboniferous.

Secret Canyon shale.-This name was applied by $\mathrm{Mr}$. Hague ${ }^{a}$ to a division of the Cambrian in the Eureka district overlying the Prospect Mountain limestone and underlying the Hamburg limestone. It consists of 1,600 feet of yellow and gray argillaceous shales, passing into shaly limestone. This formation is characterized by a fama that may be referred to the upper portion of the Middle Cambrian.

Star Peat formation. - This name was applied by $\mathrm{Mr}$. King ${ }^{b}$ to the uppermost of the two great divisions of the Triassic of western Nevada. The series consists of 10,000 feet of strata, made up of an alternation of three great limestone zones and three interposed quartzite zones. The upper two quartzites represent moderately pure siliceous sediment, while the lower quartzite closely follows the physical and chemical pecnliarities of the underlying Triassic Koipato series. The fossils of these limestones are marvelously like the St. Cassian and IIallstadt of the Austrian Alps. Directly overlying the uppermost Star Peak quartzite is a limestone carrying Lower Jurassic or Liassic forms, and succeeded upward by an immense series of argillites of nnknown thickness.

Tonto shale and sandstone.-The name Tonto was applied by $\mathrm{Mr}$. G. K. Gilbert ${ }^{c}$ in 1874 to a series of sandstones and shales lying between the subjacent granite and the superjacent limestones which occur at the mouth of the Grand Canyon in Arizona. He considers the formation of Primordial age, and it has been since found to contain an Upper Cambrian fauna. ${ }^{l}$

Trackee formation.-Mr. King ${ }^{e}$ proposed the name Pall-Ute Lake for a fresh-water Miocene lake, which is regarded as extending from the region of the Columbia River, and perhaps still farther north, far south through Oregon and Nevada into California. 'To the beds of this lake in the fortieth parallel area he gave the name of Truckee Miocene. They are made up of 150 feet or less of detrital rocks and gritty sandstones, with some conglomerate. Above these lie about 250 feet of palagonite tuff. Above this is 250 to 300 feet and more of infusorial silica, followed by 120 feet of detrital sandy rocks, containing also infusorial silica. Above these comes 60 feet of fresh-water limestone, which is succeeded upward by 250 feet of detrital grits; and the latter give away to an enormous formation of volcanic tuffs. In Nevada the thickness of these volcanic muds is 2,000 or 3,000 feet; in Oregon it is even more.

a Third Ánm. Rept. U. S. Geol. Survey, p. 255.

$b$ U.S.Geol. Expl. Fortieth Par., Vol. I, p. 346.

c Bull. Washington Philos. Soe., Vol. I, p. 109.

a C. D. Waleott, Bull. U.S. Geol. Survey No. 81, p. 245.

e Op. cit., p. $45 t$. 
Unkar formation. - This has alrearly been mentioned, under the headings Grand Canyon and Chnar, as the lowest division of the Grand Canyon group of the Algonkian in the Grand Canyon section. It is overlain conformably by the Chuar, and separated below by a great unconformity from the Vishnu-series.

Wasatch limestone.-The term was applied by King ${ }^{a}$ to an enormous body of limestone seen in the Wasatch and farther west, but not to the east. He describes it as a single body of limestone about 7,000 feet in thickness, holding its enormous volume with remarkable evenness wherever observed over Utah and Nevada. It is underlain by the Ogden quartzite, from which it is lithologically sharply distinguished. Above, it passes into the great Weber quartzite, but there is an alternation of sandstone and limestone beds at this transition and the thickness of these intercalated beds is very variable, reaching sometimes about 1,000 feet.

The lower 1,400 feet of the Wasatch limestone was regarded as Devonian. Above this is 300 or 400 feet of dark, heavy limestones carrying fossils resembling those of the Waverly group, but which perhaps are closer to the Devonian. Directly above these are 400 or 500 feet of dark beds carrying Lower Carboniferous fauna, and above these the upper 4,500 feet of the limestone is characterized by abundant Coal Measures fossils.

The term Wasatch was not retained in the Eureka section, ${ }^{b}$ the Devonian and Carboniferous being subdivided into various formations. However, these lithologic subdivisions are not readily recognizable at many other points in Nevada, and the old term is often convenient.

Weber conglomerate.-Mr. King ${ }^{c}$ described the Weber quartzite as a body of indurated sandstone and quartzite carrying occasional sheets of conglomerate, interposed between two bodies of Coal Measures limestone. He described it as obtaining a thickness of 2,000 feet in the Wasatch, 8,000 feet in the Oquirrh, and probably more in middle California. This formation overlies the Wasatch limestone and underlies the Upper Coal Measures limestone.

The same formation was recognized by Mr. Hague ${ }^{d}$ at Eureka, where it is underlain by the Lower Coal Measures limestone and overlain by the Upper Coal Measures limestone. Its thickness at Eureka, however, is only 2,000 feet. Here it consists of coarse and fine conglomerates, with angular fragments of ehert and layers of reddishyellow sandstone.

White Pine shale.-This term was applied by Mr. Hague ${ }^{d}$ to the 
uppermost of the lithologic divisions of the Devonian in the Eureka district. It consists of 2,000 feet of black argillaceous shales, more or less arenaceous, with intercalations of red and reddish-brown friable sandstone, changing rapidly with the locality. The beds contain plant impressions. The formation is underlain by the Devonian Nevada limestone and overlain by the Carboniferous Diamond Peak quartzite. These lithologic subdivisions seem to change rapidly as one goes away from the Eureka district, and have not often been certainly identified. 


\section{RANGES OF EAST-CENTRAT NEVADA.}

\section{SNAKE RANGE.}

The Snake Range lies next east of the Schell Creek Range and for the most part just west of the Nerada-Utah line. It is the most conspicuous range between the Wasatch and the Humboldt. The northern end of the range has been variously called the Deep Creek Mountains or the Ibenpah Momntains, while just south of this part of the range a transverse ridge has been called the Kiern Mountains; but here they will all be included under the general name Snake Range. The range, as thus defined, extends from about latitude $40^{\circ} 15^{\prime}$ about 135 miles in a direction a little west of south. At its southern end it runs into a group of irregular mountains, probably in large part volcanic, of which certain portions go by the name of the Cedar Mountains, and the Piñon Mountains of Lincoln Comty.

\section{TOPOGRAPHY.}

The relief of the Snake Range is in general great. The mountains are divided into irregular ridges which are broken and separated by transverse east-west gaps. By two such gaps the so-called Kern Mountains are separated from the rest of the range, and a similar but lower gap occurs just north of Wheeler or Jeff Davis Peak. This peak has the highest elevation of any between the Sierra Nevada and the Wasatch, attaining over 12,000 feet (PI. III, A). Directly sonth of this the mountains decrease rapidly in height and pass into the low volcanic peaks above mentioned.

Some of the erosion forms are interesting. On the east side of the range, between Wheeler Peak and the Kern Monntains, a number of springs furnish continual streams. At the mouths of the gulches from which such streams flow the Pleistocene wash which covers the hase of the mountains has been lowered fully 500 feet below the wash on both sides, and the stream flows through this deposit between steep banks 40 feet high. Where near-by gulches which do not contain any continual streams join the same detrital apron, the reverse is the case, the gulches being fronted by hnge alluvial fans higher than the rest of the platean.

Considering the gulches formed by these continual streams and comparing them with the neighboring gulches which do not contain springs, we find a strong contrast. Smith Creek, for example, is 
a spring flowing in the bottom of a magnificent narrow canyon, bounded by perpendicular walls 2,000 or 2,500 feet high. In these walls are a number of large holes or caves in the limestones, which evidently represent the former courses of the same spring that now emerges in the gulch bottom. From the distribution of these eaves it appears that the spring has been flowing during all the time that the canyon has been eroding and that its former underground courses have been exposed by the down cutting. The adjacent gulches, which do not continually contain running water, have $V$-shaped valleys without box canyons, and are much shallower.

In this canyon are small working mines.

\section{ARCHEAN ROCKS.}

Howell found fragments of granite in the wash which eame down from Wheeler Peak, and regarded this as Archean, underlying the undoubtedly Cambrian quartzite. Farther north, on the east face of the mountain, and on the north side of the gap which runs transversely across the range north of Wheeler Peak, the writer found abundant schistose granite in the drift and in one locality in place. Where it was found in place it seemed to lie beneath limestones which are probably Cambrian, with no intervening quartzite. Farther north, also on the eastern side of the range, one finds continually huge blocks of schistose granite mingled with the blocks of schistose Cambrian quartzite. Upon the north side of the Kern Mountains granite is found in contact with the schistose Cambrian quartzite and also with the overlying metamorphic limestones. The central portion of the Kern Mountains is made up of this granite, with the Cambrian rocks on the flanks. A specimen examined microscopically proved to be a biotite-muscovite-granite, approaching alaskite. On the borders of the granitic mass are found siliceous granitic dikes, which cut the Cambrian quartzite-schists. At one locality, which is on the southwest side of Pleasant Valley and near the State line, is found a broad belt of confused alaskite dikes showing a tendency to change into a muscovite-biotite-granite on the one hand and into large quartz veins on the other.

Howe ${ }^{a}$ notes that at the head of Deep Creek, only a few miles north of Pleasant Valley, the erosion of the creek has laid bare granite underlying the quartzite and limestone. From here northward to Uiyabi Pass, not far from the northern end of the range, he notes that the base of the range is granite, overlain and flanked on the west by quartzite and limestone.

From these evidences it would seem that the limestones and overlying quartzites which form the base of the stratified series in the Snake Range, and which will be presently shown to be Cambrian, are ordinarily underlain by granite. But in at least one locality similar 


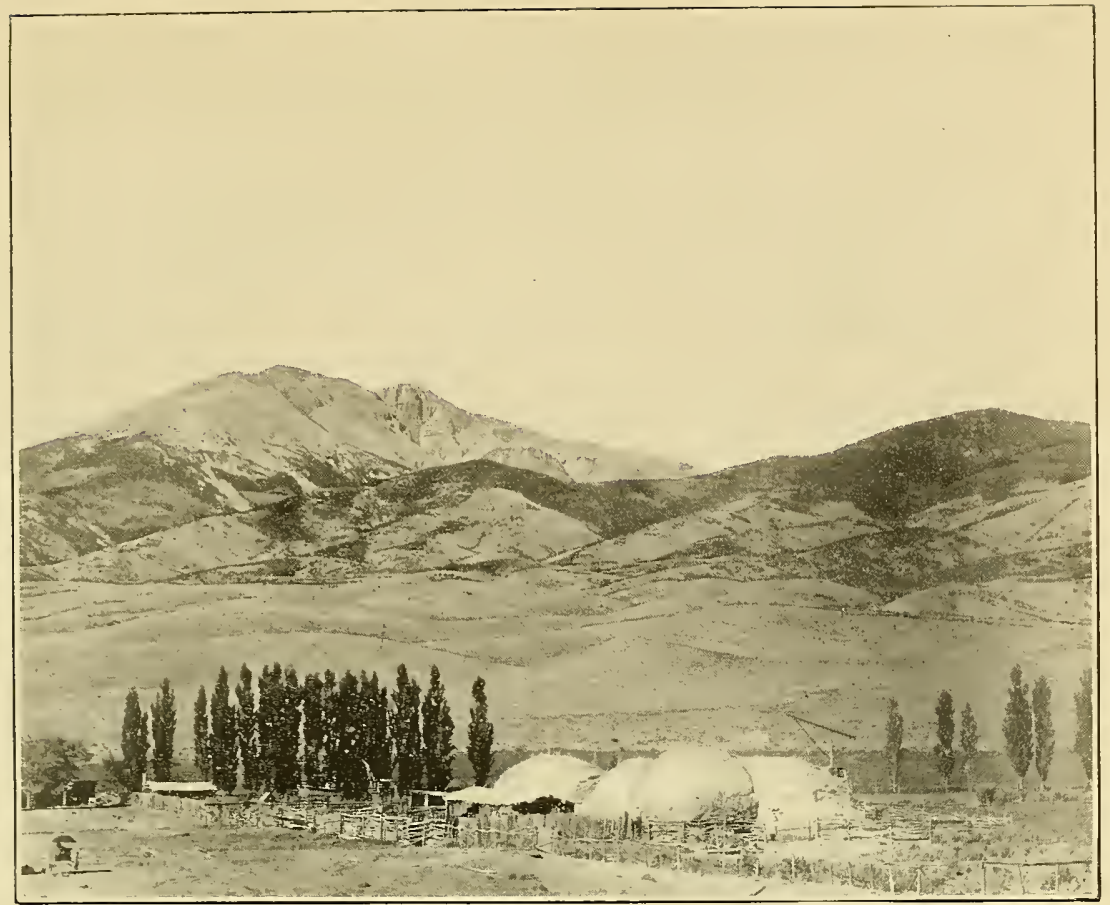

A. JEFF DAVIS OR WHEELER PEAK, SNAKE RANGE, FROM ROBINSON'S RANCH.

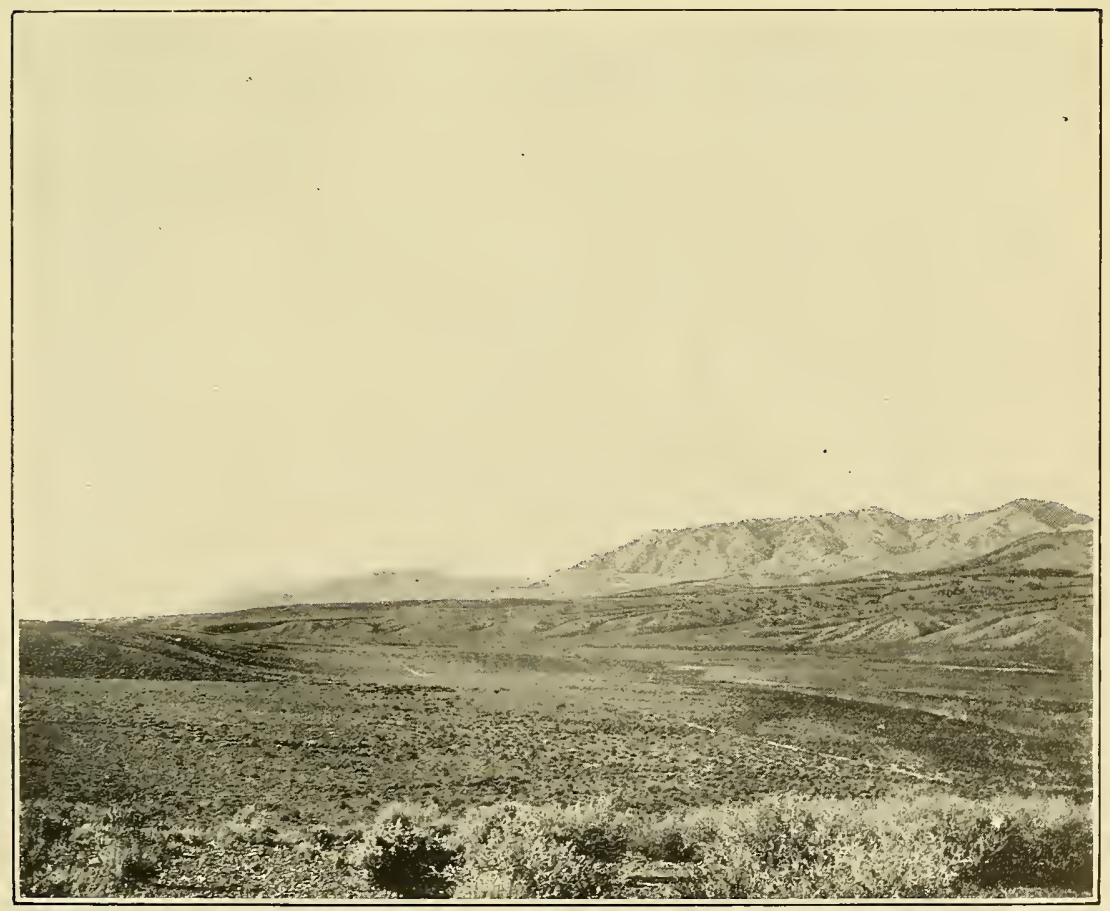

B. NORTH END OF SCHELL CREEK RANGE, FROM ANTELOPE RANGこ.

Showing also the Tertiary and Pleistocene valleys between the two ranges. 

granitic rock is locally intrusive into the Cambrian strata, and the same has been suspected in other places. From the fact, however, that the intrusive phenomena are of minor importance, and also from the circumstance that where the Cambrian quartzite is schistose the underlying granite also shows signs of movement, the writer inclines to the belief that the granite as a whole is really Archean and is the basement upon which the Cambrian quartzites were laid down. So thick a series of quartzites (amounting to several thousand feet) naturally suggests a granitic land mass as their sonrce. As regards the occasional intrusive phenomena, it is possible that these represent occasional outbursts of molten rock which found its way from the lower and more heated regions up through the erust of hard Archean granite and into the overlying Cambrian, being intrusive into the Upper Archean as well as into the quartzites, althongh belonging practically to the same body as the basement granite. The writer would suggest that this explanation may possibly apply to Big Cottonwood Canyon, in the Wasateh, near Salt Lake City, where the granite was originally believed to be Archean, but where later observers have noted intrusive phenomena. ${ }^{a}$

\section{SEDIMENTARY ROCKS.}

\section{CAMBRIAN.}

In the souther'n part of the range, at Wheeler Peak, there are heavy quartzites dipping in all directions, forming a gentle quaquaversal. Howell ${ }^{b}$ notes the same quartzites for some distance south of the peak, overlain by heary bluish-gray limestones. He estimates the limestones as 4,000 to 5,000 feet thick, and the underlying quartzite at not less than 1,000 feet.

North of Wheeler Peak, at the mining camp at Osceola, the writer observed these quartzites, and found on the mountain just south of the camp abont 500 feet of pure white quartzite underlain by about 2,000 feet of massive gray quartzite, with some silvery slate. At Osceola there is an east-west fault which brings together a massive brown eraggy-weathering quartzite on the north side and the silvery slate with quartzite bands on the south: Above the quartzite, one mile east of Osceola, there is a high bluff of dark-blue frosty lustered siliceous limestone with indistinct, probably organic, lnarkings, similar to the limestones just west of here, in the Schell Creek Range. About a mile farther east the slight westerly dip of the limestones brings up the same underlying silvery slates as were noted in the neighborhood of Osceola and also in the Schell Creek section at the same horizon. The limestones in the neighborhood of Osceola were estimated at 1,000 feet thick, while the slates, as exposed in the Schell Creek section, were roughly estimated at from 4,000 to 5,000 feet. A short

a C. R. Van Hise, Correlation Papers, Archean and Algonkian: Bull. U. S. Geol. Survey No. 86, p. 289.

bU. S. Geog. Surv. W. One Hundredth Mer., Vol. III, p. 24 I. 
distance farther east the slates are underlain by 300 feet of brown quartzite like that at Osceola, below which comes 600 feet of gray quartzite.

The following observations have been directly communicated to the writer by Mr. F. B. Weeks, who made an extended trip in the Great Basin region in the summer of 1900 :

A few hundred feet below the summit of the ridge south of Osceola fossils were found in the limestone and have been determined by Mr. Walcott as Lower Cambrian.

About 8 miles northeast of Osceola the center of the range is occupied by hard and massive drab and blue limestones, in which fossils collected at two localities have been determined by Mr. Walcott to be Middle Cambrian forms. These Cambrian limestones are succeeded by Ordovician limestones.

We have, then, in the neighborhood of Osceola a section of sedimentary rocks resting upon the basal granite and consisting of at least 2, 500 feet of quartzites, suceeded by a thickness of silvery, somewhat micaceous slates of uncertain but probably considerable thickness, and these by at least a thousand feet of metamorphic limestones. The section is identical with that just west of here, in the Schell Creek Range.

About 20 to 25 miles south of Wheeler Peak Cambrian limestones, overlain by Ordovician limestones, were also observed by Mr. Wreeks.

All along the eastern side of the Snake Range, north of Wheeler Peak, is found the same section, although the overlying silvery slates often become more quartzitic and pass into quartzite-schists. Just north of the east-west gap crossing the range north of Wheeler Peak a series of 2,500 to 3,000 feet of craggy-weathering brown or black considerably altered limestones, reticulated by many veins and highly jointed, was gone through. In this limestone no fossils were seen, but above it is found limestone with Coal Measures fossils. The lower limestone is believed to be in part Cambrian, for below it was found a belt of about 200 feet of black shale, in which a number of fossils were collected, which were determined by Mr. C. D. Walcott to be Cambrian. Bolow this shale comes a peculiar 50-foot bed of white marble, banded with gray, and beneath this upward of 1,500 feet of highly schistose quartzite, producing the effect of a silvery slate.

From here north to the transverse gap which euts across the range sonth of the so-called Kern Mountains, one finds almost continuously the same quartzite-schists at the bottom of the section, sometimes nearly approaching the condition of a mica-schist. Above this come heavy bedded limestones, which weather brown, and which carry indistinct and indeterminable fossil remains. Midway between the northern end of the main portion of the Suake Range, south of the Kern Mountains, and the Kern Mountains themselves, the same metamorphic limestone was found in a butte.

From observations all along this face of the range the thicknoss of the metamorphic limestone was estimated at about 5,000 feet. A spec- 
imen of the limestone examined appeared to contain indistinct traces of organic forms, but was thoroughly recrystallized.

At the southeastern end of the Kerm Mountains the same highly altered limestone was found. Farther northwest, toward the heart of the mountains, this is underlain by highly altered quartzite-schists with an intercalated band of marble similar to the section described farther south. The schist is cut by numerous dikes of siliceous granitic rock, as above described. Thin sections of the schist examined proved that it was origiually quartzite, but the more metamorphosed specimens showed the development of biotite and muscovite along sliding planes, producing a muscovite-biotite-quartzite-schist.

In the mountains on the north side of Pleasant Valley Mr. Howell ${ }^{a}$ has noted that the range is composed of quartzite overlying granite and itself overlain by limestone. He also notes that there is frequently a little sliale between the limestone and the quartzite. At Uiyabi Pass he estimated the limestone at from 3,000 to 5,000 feet. He found there only from 200 to 400 feet of quartzite between the grainite and the limestone.

Along the north side of Pleasant Valley, at the base of the Deep Creek Mountains, the writer noted the continuation of the altered limestones that overlie the quartzites and shales of the Korn Mountains. This limestone was traced northwestward to the gap though which the road runs northward to Deep Creek. Immediately west of here it is replaced by less altered limestone carrying Coal Measures fossils.

We have, therefore, extending nearly the whole length of the Snake Range, for 100 miles at least, a heavg quartzite resting upon a basement of granite and overlain by slates, which in turn are overlain by massive metamorphic limestones. The thickness of the quartzite in the neighborhood of Osceola was estimated at not less than 2,500 feet, while Mr. Howell found only 200 or 400 feet at the northern end of the Deep Creek Range. The thickness of the overlying shales or slates seems to be likewise small at the northern end of the range, while in the neighborhood of Osceola it is considerable, and was roughly estimated by the writer, partly by comparison with the adjacent Schell Creek Range section, to be 4,000 to 5,000 feet. The thickness of the massive limestones above was estimated by $\mathrm{Mr}$. Howell at Wheeler Peak at from 4,000 to 5,000 feet; by the writer, at a point some distance farther north, at about 5,000 feet; and by Mr. Howell at Uiyabi Pass at from 3,000 to 5,000 feet. But at the latter locality Howell found Carboniferous fossils, so that at least the upper part of the limestone here can not be included with the Cambrian.

The whole section corresponds in its chief features to the Cambrian section of the Schell Creek.Range, the Highland Range, and the section at Eureka, and the Cambrian fossils found in the shale horizon above 
mentioned confirms the correlation. We have therefore a roughly estimated thickness of at least 12,500 feet of Cambrian in this range. SILURIAN.

On the road which runs east from Osceola there was observed a haud white quartzite about 400 feet thick, which was recognized in the field as similar in every respect to the silnrian Eureka quartzite of the Eureka section.

Northeast of this locality, about + miles north of Robinson's manch $(\mathrm{Pl}$. IV, $A$ ), a compact conglomerate, which will presently be described as probably Mesozoic or 'Tertiary, contains large quantities of similar white quartzite, together with limestone fragments. From some of the limestone fragments the following Ordovician (Lower Silurian) fossils were obtained and identified by Prof. E. O. Ulicich :

Leperditia falnulites Comrad, variety.

Isochilina, sp. mdet.

Lophospira, sp. cf. L. bicincta Hall.

Fragments of an Orthis near Tricenaria.

These conglomerates pass laterally into limestones and white quartzites, whence they are derived. The Leperditia above mentioned is found in the Pogonip terrane at Eureka, so that the limestone here is very likely of the same horizon. This also strengthens the previous tentative assignment of the quartzite to the Silurian.

Eight miles northeast of Osceola, in the center of the range, Mr. F. B. Weeks ${ }^{a}$ observed, overlying Cambrian limestones, a different series of purple, lrab, and white limestones, in which the following Ordovician fossils were found (determined by Professor Ulrich):

Fragments of crinoid columns.

Orthis (cf. lonensis and holstoni).

Dalmanella (cf. testudinaria).

Dalmanella (cf. emacerata).

Dalmanella (cf. perveta and pogonipensis).

Brachiopod of undetermined relations.

Machurea.

Eccyliopterns (near owenamns (H. \& W.) Ulr.).

Helicotoma sp. nndet.

Lophospira?

Cyrtoceras? (very small).

Related to Serpulites dissolntus Billings.

Asaphus-fragments. (1)

Asaplius.

Asaphus sp. mulet.

Asaphus (cf. curiosus).(4)

Bathyurus sp. undet.

Cyphaspis ? sp. nndet.

Two rndet. trilobites.

Illænus (cf. americanns Billings).

Amphion (near salteri Billings).

Amphion nevadensis Walcott. 

Mr. Weeks states that about 20 to 25 miles south of Wheeler Peak, in the bold escarpment 1,500 to 2,000 feet in height which faces Spring Valley, the Ordovician limestones abut against the Cambrian with a very high angle of dip. In this series the following fossils, determined by Professor Ulrich, have been collected:

First lot.

Orthis (near tricenaria).

Orthis (? type of plicatella).

Orthis (cf. bellarugosa).

Orthis n. sp. (near O. holstoni Safford).

Dalmanella (type of testudinaria).

Dalmanella (type of perveta).

Dalmamella.

Hormotoma (near gracilis).

Leperditia bivia White.

Leperditella sp.

Leperditella? sp.

Schmidtella n. sp. (near crassimarginata).

Bathyurus (? Dikellocephalns). Occurs elsewhere.

Batlyurns.

Amphion.

Asaphns.

Asaphus.

Asaphus? curiosus (Billings) Walcott.

\section{Second lot.}

Fragments of large eystidean or Carabocrinus.

Orthis tricenaria-costalis.

Orthis pogonipensis?

Orthis n. sp. (near O. holstoni Safford).

Eccyliopterus-fragment.

Endoceras of new type.

Leperditia bivia White.

Leperditia n. sp. (near bivia and fabulites).

Leperditia n. sp. (semipunctate).

Schmidtella n. sp.

Illænus sp. (? Thaleops).

Amphion nevadensis Walcott.

Bathyurus? n. sp. (Occurs at many localities.)

These fossils are types that were found by Mr. Walcott in the Lower Pogonip (Ordovician) at Enreka, and it is not probable that an erosion interval of much importance occurs at this horizon.

The Carboniferous strata lie unconformably upon the Ordovician in nearly horizontal position, and form the remaining portion of the Snake Range. Between the Ordovician and the Carboniferous there is a great interval of nondeposition, since the Eureka quartzite, the Lone Mountain limestone of the Silurian, and the whole of the Devonian as exposed at Eureka, are wanting in this section. 


\section{CARBONIFEROUS.}

Mr. F. B. IVeeks ${ }^{a}$ reports that near the southern end of the Snake Range the Lower Silurian (Pogonip) rocks are directly overlain by Carboniferous limestones. There is here a gap in the Paleozoic section. The upper formations of the Silurian as exposed at Eureka (the Eureka quartzite and the Lone Mountain limestone) are wanting; as well as the whole Devonian section ( 8,000 feet thiek at Eureka). In a low pass near the sonthern end of the Snake Range Carboniferous fossils were found, which were determined by Dr. Girty as containing species of Zaphrentis, Syringopora, and Reticularia.

In the section across the range eastward from Osceola, and just north of Wheeler Peak, the Cambrian rocks are succeeded to the east by a conglomerate made up chiefly of the peculiar metamorphic Cambrian limestones, and also containing pebbles of the quartzite and ealeite veins which these limestonns hold. Between this locality and the next ontcrop to the west (which consists of Cambrian quartzite and limestones), there is a gap of a few miles, covered by a drift in which no rock outerops were observed. Succeeding this on the east is dark-gray, somewhat fetid, calcite-veined limestone, which is very fossiliferous. This locality yielded the following Upper Carboniferons fossils, which were determined by Dr. George H. Girty:

Fistulipora? sp.

Productus n. sp.

Productus sp.

Marginifera splendens.

Spirifer boonensis.

Ambocoelia planiconvexa.

Seminula subtilita.

This is lithologieally the same rock as the Upper Carboniferous on the west side of the Schell Creek Range, where it also abuts against the Cambrian.

This fossiliferous bed is succeeded farther east by similar limestones and by beds of ferriferous quartzite. After about three-quarters of a mile there comes in about 400 feet of hard white quartzite, which is supposed to be Silurian. ${ }^{b}$ The dip of this flattens so that it forms the outcrops and the tops of the hills for a half mile east. Then comes in, farther east, conglomerate made up of limestone fragments in a reddish, finely triturated matrix. The fragments yielded the following Upper Carboniferous fossils, which were identified by Dr. George II. Girty:

Productus prattenianus.

Productus portlockianns?

Marginifera splendens.

Spirifer cameratus.

Seminula mira? 
Proceeding northward from this point along the eastern face of the mountains, there was found, about 4 miles north of Robinson's ranch, a compact red eonglomerate, made up mostly of white quartzite and erystalline limestone full of ealeite veins. The limestone fragments yielded the following Ordorician (Lower silurian) fossils, which were identified by Dr. George II. Girty: Fragments of Orthis sp. and Leperditia bivia.

From another fragnent the following Upper Carboniferous fossils vere obtained: Rhombopora? sp. and lamellibraneh fragments.

The angular shape of these fragments proves a shore formation. Two hundred yards north the conglomerate passes laterally and rapidly into the solid rocks from which it is derived-blaek, darkhlue, and gray limestones, thoronghly seamed and crushed, and white quartzite, having nearly the same attitude as the eonglomerates. The solid limestone carries fossils like those in the conglomerate. Following the section northward, one passes through 2,500 or 3,000 feet of limestone to a belt of black shale in which Cambrian fossils were found, as determined by $\mathrm{Mr}$. C. D. Walcott.

From here northward as far as Pleasant Valley no Carboniferous fossils were found. On the north side of Pleasant Valley the metamorphic limestones, which have bcen referred to the Cambrian, are succeeded to the west, near the gap where the road to Deep Creek runs, by comparatively unaltered although calcite-veined limestones, which earry the following Upper Carboniferous fossils, as determined by Dr. George H. Girty:

Romingeria? sp.

Fenestella sp.

Productus prattenianns.

Seininula mira?

Pugnax rockymontanus.

Dielasma? sp.

Edmondia? sp.

Pleurotomaria sp.

Bellerophon crassus?

Farther north, at Uiyabi Pass, near the northern end of the range, Mr. Howell found a few fossils, among them Fusulina cylindrica, whieh indicate Carboniferous age. These fossils were found in Carbonifer:ons limestone which lies above the Cambrian quartzite, and probably in the upper part of the limestone, the lower part being presumably Cambrian. $^{a}$ This limestone, aecording to Mr. Howell, ${ }^{b}$ is about 4,000 or 5,000 feet thick.

\section{MESOZOIC OR TERTIARY.}

As described above, there was found on the road leading east from Oseeola a folded conglomerate made up of coarse limestone frag- 
ments carrying Upper Carboniferous fossils and evidently derived from immediately adjacent Upper Carboniferons strata. This conglomerate may be part of a series which was examined for 4 miles farther east, and seems to consist mostly of gray sandstones. The sandstones are tilted toward the west, sometimes at angles of $45^{\circ}$, but in one place seem unconformable with a knob of underlying limestone. In the momntains a few miles north of Robinson's ranch, as before noted, there was found a compact red shore conglomerate, composed of limestone fragments carrying Ordovician and Upper Carboniferous fossils. This is 100 feet thick, and below it eomes 50 feet of consolidated black limestone talus; below the talus is again 500 feet of reddish conglomerate. This series dips $45^{\circ}$ to the west, but 200 yards farther north it seems to pass laterally into the solid rocks from which it is derived.

It thus appears that above the Upper Carboniferous limestone, and separated from it by a listinct erosion interval, if not by an nuconformity, is a thick series of gray sandstones and limestone conglomerates. We have no means of determining the age of these rocks. In its physical characters the series corresponds ronghly to the Triassic described in the Wasatch and eastward by Mr. King. ${ }^{a}$ It may also be possibly Eocene. ${ }^{b}$

PLIOCENE.

At the sontheastern end of Pleasant Valley is a considerable area of level-topped lills, which rise about 1,500 feet above the valley, and are symmetrically eroded. They are composed of horizontal, slightly consolidated sands, with ledges of conglomerates. At the base of the series the material is coarse and little arranged.

Just north of here, on the west side of Deep Creek Valley, Mr. Emmons ${ }^{c}$ has described beds of fine sand and marls, with some gravel conglomerate, and notes that they have a general lithologic resemblance to the Humboldt Pliocene.

The Pleasant Valley strata also correspond in general appearance to the supposedly Pliocene sands and gravels which are found over so large a part of Nevada. They are far above the shore of Lake Bonneville, as indicated by $\mathrm{Mr}$. Gilbert, ${ }^{d}$ and therefore appear to belong to a body of water more ancient and probably more extensive than the Pleistocene lake

PLEISTOCENE.

Mr. Emmonse noted at the northern end of the Deep Creek (or Ibenpah) Range the terraces of a former lake, of which the highest was

"U. S. Geol. Expl. Fortieth Par, Vol. I, pl. 260, 266, 344.

bIbid., p. 37.

c Idem, Vol. Il, p. 475.

aMon. U S. Geol. Survey Vol. I, map.

eOp crt., p. 473 
about 800 feet above the desert level. This is perhaps one of the terraces of the Pleistocene Lake Bonneville, afterwards described by Mr. Gilbert.

\section{IGNEOUS ROCKS.}

LAVAS.

At the sontheastern end of Pleasant Valley oceurs a series of small buttes of hornblende-andesite. On the west end of this valley a moderately large area at the base of the mountains is of augite-alentite.

DIKE ROCKS.

Along the north side of the Kern Mountains, in Pleasant Valley, many aeid dike rocks, varying from siliceous alaskite to muscovitebiotite-granite, were found cutting the Cambrian quartzites and limestone. Associated with these dike rocks are abundant quartz veins. It is believed that these dikes have some connection with the probable Archean granite whieh underlies the quartzites. A speeimen of this granite, taken a few miles west of the dikes, proved to be biotite-muscovite-granite.

\section{STRUCTURE.}

FOLDS.

The general strueture of the Snake Range, between Wheeler Peak and the Kern Monntains, appear's to be antielinal, although the roeks are mostly worn away from the eastern limb. The axis of the fold runs along the east side of the mountains and is marked by a northsouth depression, with high hills to the east and the bulk of the range to the west. 'The general dip on both sides of the axis is perhaps not more than $20^{\circ}$, although it inereases locally to $45^{\circ}$ and even more.

In the neighborhood of Wheeler Peak, also, the roeks form a gentle anticline. There is also cross folding, with an east-west axis, so that the peak oecupies the eenter of a quaquaversal. A short distance south of the peak the western half of the principal north-south striking antieline is removed, leaving the ridge monoclinal. ${ }^{a}$

At the northern end of the range $\mathrm{Mr}$. Howell ${ }^{b}$ noted that the strueture of the range is antielinal at Uiyabi Pass, but from there to Pleasant Valley it is apparently monoclinal, only one limb of the anticline being exposed.

The Kern Mountains, south of Pleasant Valley, appear to eonsist of an antielinal fold, with northwest-sontheast axis transverse to the general trend of folding

FAULTS.

Mr. Howell ${ }^{b}$ noted a eross fault rumning east and west about $t$ or 6 miles north of Wheeler Peak, having a downthrow to the south. 
The writer recognized this fault, and 4 or 5 miles north of it a parallel fault, which seems also to have been downthrown to the south.

Mr. Weeks ${ }^{a}$ states that about 10 miles northeast of Osceola, in the central part of the range, the Cambrian limestones are broken by numerous faults which strike northwest and southeast. The massive blue limestones which form the upper part of the series are repeated several times by small faults of 200 to 300 feet throw. The general dip of the Cambrian series is to the north-northwest, and the dip of the Ordovician to the east-northeast. There appears to have been an upthrust of the Cambrian which has brought the successive limestone beds of the series in juxtaposition with the Ordovician. The existence of a heavy fault between the Cambrian and Ordovician is clearly seen in the southern portion of the Snake Range.

On the north side of the Kern Mountains a belt of quartz veins and siliceous granitic dike rocks, rumning northwest along the base of the mountains, appears to be along a fault zone. On the north side is the crystalline nearly black Cambrian limestone, while on the south side come schists which represent the top of the underlying Cambrian quartzite. The vertical separation of the fault is probably at least several hundred feet.

ORES.

At Osceola, just north of Wheeler Peak, the Cambrian quartzites and slates carry gold. Considerable placer and some vein gold has been taken from this district.

On the east side of the range there are small mines and prospects in a number of places. In some localities the coincidence of mineralization with the presence of a spring flowing in a box canyon leads to the hypothesis that it was these same waters which formerly brought about the ore deposition. Along the walls of such canyons, high above the present bed, ancient water channels in the limestone rock show that the spring has existed since near the time when the erosion of the canyon began.

\section{CEDAR RANGE AND CLOVER VALLEY MOUNTAINS.}

The Cedar Range consists of broad, irregular, often mesa-like hills, lying south of the Snake Range and northeast of Pioche. Southwarl from the Cedar Range, and between it and the Mormon Range, there lies to the east of Meadow Valley a wide area of irregular mountains with no definite system of ridges. In these mountains is Clover Valley, whenee is taken the name applied here.

The Cedar Range and the Clover Valley Mountains may be considered together for purposes of description. They have been partly mapped by the Wheeler survey, ${ }^{b}$ and they have been observed by the writer at several points. So far as known, they consist entirely of lavas. 
The geology of these mountains has not been studied in detail, but it is undoubtedly much the same as that described in Meadow Valley Canyon, ${ }^{a}$ which is a chasm cut deep into the same voleanic series. By analogy with the rocks in this canyon, we may suppose that the lavas of the mountains under consideration are associated with derived sediments and that these lavas were ejected at different periocis. The rock species will probably be found to be varied, ranging, as in Meadow Valley Canyon, from basal rhyolite through andesites, dacites, latites, etc., to the youngest rhyolite and olivine-basalt.

\section{ANTELOPE RANGE.}

The Antelope Range is a comparatively insignificant group, about 30 miles long, lying just west of the northernmost portion of the Snake Range (Deep Creek Range).

The central part of the range possesses a topography of considerable relief, with an especially bold face on the east side (Pl. IV,$B$ ), while on the north and on the south ends the mountains give way to low hills, which finally disappear under the Pleistocene detritus of the valleys.

SEDIMENTARY ROCKS.

On the eastern side of the range, about 3 miles west of Warm Springs, the Eureka quartzite is exposed near the base of the mountains, measuring about 200 feet in thickness. Above this come 700 to 800 feet of dark-blue (probably Lone Mountain) limestone, having the characteristic texture of this formation in the Eureka district. From here to the crest of the range comes limestones (probably Devonian?) consisting of dark-blue and gray alternating bands. From the extreme base of the mountains the following fossils were found: Leperditia bivia? White (very poor); Dalmanella perveta? They are Ordivician (Lower Silurian) species, as determined by Prof. E. O. Ulrich. These fossils are characteristic of the Pogonip horizon at Eureka.

To the north of this locality, along the eastern face of the mountains, the strata lower gently, so that the probable Lone Mountain and Nevada formations (Upper Silurian and Devonian) extend for several miles. To the sonth the strata rise and the Eureka quartzite passes half way to the top of the mountains, exposing the underlying Pogonip (Lower Silurian) beds.

This belt of stratified rocks is cut off to the north and to the south by the volcanic rocks which form the greater part of the range.

\section{IGNEOUS ROCKS.}

Along the eastern base of the range, at the foot of the mountains composed of Paleozoic strata, there is a belt of foothills about 3 miles 
wide composed of lava. The same lava evidently underlies the detrital deposits in the whole valley between the Antelope Mountains and the Kiern Mountains in the Snake Range, as is evidenced by occasional volcanic buttes which project above the Pleistocene detritus. A few miles sonth of Warm Springs, near Antelope Spring, the volcanic rock invades the stratified rock in large masses and soon forms the whole of the mountains. From this point along the road which leads from the southern part of the Antelope Mountains to Schellbourne and Cherry Creek there is nothing but the same reddish lava, and, so far as was seen, the lava seemed to extend northward to the end of the range.

Specimens of the lava collected at various points thronghont the southern part of the range prove to be in general a pyroxene-aleutite. It is essentially the same rock which stretches across the intervening valley to the foothills at the western base of the Snake Range, north of the Kern Mountains. The same body of lava also fills the whole valley between the Antelope Monntains and the northern part of the Schell Creek Range, and extends to the summit of this range.

The lava constituting the northern part of the range has been described by Mr. Emmons" as rhyolite.

\section{STRUCTURE.}

Where the Paleozoic rocks are exposed in the Antelope Range the strike is in general north and south and the dip $20^{\circ} \mathrm{W}$. On the western borders of the Snake Range, directly east of here, they have a general dip of $15^{\circ} \mathrm{E}$. The intervening valley is, therefore, perhaps anticlinal. The structure of the stratified rocks of the Antelope Momntains is obsenred by the overlying lavas.

\section{SCHELL CREEK AND HIGHLAND RANGES.}

The Schell Creek Range has its northern end at the fortieth parallel (Pl. III, B) and extends from here sonthrard about 100 miles to Patterson. Here a slight gap separates it from the IIighland Range, which is a direct continuation of it. The Highland Range extends from Patterson sonthward for about 80 miles, when it runs into the Meadow Valley Range, from which it is separated by no distinct gap. The Mcadow Valley Range will be described later.

\section{SEDIMENTARY ROCKS.}

CAMBRIAN.

At the northern end of the Schell Creek Range, in the vicinity of Schellbonrne, Mr. Emmons ${ }^{b}$ noted limestones carrying Cambrian fossils and overlying heavy bodies of Cambrian quartzite. Mr. Gilbert ${ }^{c}$

a U. S. Geol. Expl. Fortieth Par., Vol. II, p. 485.

$b$ Ibid., p. 486.

c U.S.Geog. Su1v. W. One Hundredth Mer., Vol. III, pp. 30, 182. 
noted also Cambrian fossils near Schellbourne and also both north and south of it. In Ruby IIill Canyon, about 10 miles south of Schellbourne, $\mathrm{c}_{\mathrm{i}}$ uartzites were noted at the eastern base of the range, overlain by several thousand feet of limestones. Abont 18 or 20 miles south of Ruby Hill and a few miles south of Piermont, at Whites Peak, the quartzites have risen to the crest of the range and together with the associated schists display a thickness of over 11,000 feet. The strata dip $15^{\circ}$ or $20^{\circ} \mathrm{W}$., and the overlying limestone appears on the west flank of the peak. Southward from Whites Peak the quartzite gradually sinks again, and the crest of the range is made up of the overlying limestiones.

The writer crossed the Schell Creek Range at Schellbourne and found the eastern side composed of volcanic rock. $A$ quarter of a mile east of the summit dark-blue massive limestone begins. Underlying this limestone, on the west side of the pass, occurs dark-blue limy shale, containing Cambrian fossils, as determined by Mr. C. D. Walcott.

This shale is several hundred feet thick and contains a bed of finegrained brown-weathering quartzite 100 feet thick. Similar fossils are found above and below the quartzite. Beneath the shale comes a well-bedded limestone.

In the west-facing scarp of the mountain, directly north of the pass as seen from Schellbourne, the section examined may be seen finely exposed. From stratigraphic evidence the writer would be inclined to correlate the uppermost limestone with the Hamburg formation of Eureka, the shales with the Secret Canyon formation, and the lower limestones with the Prospect Mountain limestone. An estimated section of the mountains here is as follows:

Section near Schellbourne.

Feet.

Hamburg limestone.. . . . .

Secret Canyon shale . . . .

Prospect Mountain limestone ... . . . 1, 800

Neither the top nor the bottom of the section was observed.

About 30 miles south of Whites Peak and Piermont the writer erossed the Schell Creek Range along the main road between Ely and Osceola. On the east side of the summit (which is not high at this point) limestone carrying abundant Carboniferous fossils appears to abut against massive dark-blue metamorphosed limestone, reticulated with calcite veins, and associated with beds of marble. Immediately below the metamorphic limestone beds is a ferruginous and micaceous slate seam, contorted and containing veins of quartzite and calcite. This limestone and underlying schistose slates constitute the whole eastern part of the range.

No fossils were found at this point, but the beds are probably to be correlated with the Cambrian limestones and unclerlying shales at 
Whites Peak, at Rnby Hill, and Schellbourne. The succession and the general character of the rocks are also similar to those of the Cambrian limestones and shales in the Highland Range in the vicinity of Pioche and in the Snake Range directly east of here, in both of which localities Cambrian fossils have been found.

On the west side of the range, north of the locality just described and directly east of Ely in the Egan Range, the ridge which flanks the main Schell Creek Range on the east has along its erest what appears from a distance to be the white Eureka quartzite of the Silurian, dipping west at a constant angle of about $30^{\circ}$. Between this ridge and the main range there is a parallel depression which runs along the axis of an anticline, for to the east of it the strata have an easterly dip of from $20^{\circ}$ to $30^{\circ}$. On the ridge itself there comes in below the Eureka quartzite struta resembling the thick, comparatively soft limestones of the Pogonip formation, and beneath this, in the bottom of the valley, are exposed massive gray limestones, which aro perhaps Cambrian. These Cambrian and Silurian rocks do not extend sonth past the end of the ridge which forms the western ligh limb of the anticline, but are replaced to the sonth by the Devonian, the two regions being apparently separated by a heavy east-west fault.

Mr. Howell ${ }^{a}$ has described the rocks at the southern end of the Schell Creek Range. He notes that at Patterson a heavy bed of quartzite is exposed, dipping abont $45^{\circ}$ ESE. A few miles to the north this is covered conformably by bluish-gray limestone. No fossil remains sufficient for determination were found, but the limestone was correlated on lithologic grounds with the supposedly Carboniferous limestones of the Snake Range and the Highland Range. Inasmuch as at least the sonthern portion of the Highland Range consists of Cambrian limestones, which were classed by Mr. Howell as Carboniferous, but subsequently definitely determined as Cambrian, and since the same Cambrian series ocenrs in the Snake Range, it seems likely that these rocks may also be Cambrian. ${ }^{b}$

At the north end of the Highland Range, just south of Patterson, Mr. Howell found Carboniferous limestone well characterized by fossils.

At Bristol, on the west side of the range, and about 30 miles south of Patterson, Mr. Howell noted quartzite at the base, while the whole npper portion was highly metamorphic limestone. 'This section, so far as it goes, accords with the Cambrian section of the southern end of the range, as will be mentioned later.

Mr. Walcott ${ }^{c}$ noted on the western side of the range, at the same locality as just mentioned, the occurrence of the Eureka quartzite. It is possible that this is the same quartzite mentioned by Mr. Howell.

a U. S. Geog. Surv. W. One Hundredth Mer., Vol. III. y 242.

$b$ Subsequeat to tha writing of this MIr.F. B. Weeks collected Cambrian fossils near Patterson, in these limestones, abore the quartzites.

c Bull. U. S. Geol. Survey No. 30, p. 36. 
The writer passed only a few miles from Bristol, proceeding from Coyote Spring over stampede Gap, and he also mapped the silurian as extending across the valley to Bristol, and indicated in his notes the probable oceurence of the Eureka quartzite.

At Stampede Gap the range, with the exception of some very low foothills at the western base, which will be referred to later as probably Devonian or Silmian, is composed of about 800 feet of mingled limestone and slate orerlain by abont 1,400 feet of massive limestone containing siliceous berls. Some of these upper limestones carry indistinct and indeterminable organic remains. A mottled structure, seeming to indicate the former presence of coral remains in the now altered rock, is common, heing the same structure as observed in the Cambrian roeks of the Schell Creek Range, described above as oceurring about 30 miles somth of Piermont. In the limestones at both localities metamorphism has cansed the same peculiar pitted appearance which results from the segregation of metamorphic minerals.

In the Highland Range, about $t$ miles sonth of Stampede Gap and about the same distance southwest from Pioche, the entire range appears to be of Cambrian strata, and Mr. Waleott " has measured the following section:

Section in Highland Range 4 miles south of Stampede Gap.

1. Quartzite -

Feet.

2. Limestone and shales, argillaceons and arenaceous _....... 1,450

3. Massive limestone.

3,000

Total

4,800

The fossils which he collected at various poinis enrelated this section with the Cambrian at Enreka, the lasal quartzite corresponding to the Prospect Mountain quartzite.

In the Highland Range, south of Bennetts Spring, the writer has noted the probable continuation of the Cambrian section for a distance of 5 or 6 miles at the very least, the section being substantially the same as between Bennetts Spring and Stampede Gap. From the eastern base of the Highland Range abundant quantities of brown quartzite, probably representing the basal Cambrian quartzite of Mr. Walcott's section, come down into the valley drift. This quartzite is probably overlain by the Cambrian limestone, for the strata appear horizontal on the east side of the Highland Range throughout practically its whole length.

At Pioche Mr. Howell ${ }^{b}$ noted 400 feet of highly metamorphic bluegray limestone, and below this about 400 feet of shales, which yielded abundant Cambrian fossils. Below these shales is an unknown thickness of quartzite. He correlated this quartzite with the Cambrian quartzites of the Snake and Wasatch ranges. Mr. WValcott ${ }^{a}$ has also 
studied the Cambrian section at l'ioche and finds a thickness of the basal quartzite of 1,200 feet on the west face of the Ely Range, a few miles to the west of the town of Pioche. Mining operations have thrown ont large masses of shales carrying Cambrian fossils, which Mr. Walcott ${ }^{b}$ has described and correlated with a bed of the Highland Range section. Similar fossils were also collected at the same locality by the writer. This horizon is well up in the shaly limestone which overlies the basal quartzite.

Three or 4 miles southeast of Pioche, along the road to Panaca, what is probably the basal quartzite is slightly exposed, immediately overlain by the shales. From these shales Mr. Walcott collected a number of Cambrian fossils. The writer also collected fossils from this point.

\section{SILURIAN.}

In the western face of the Schell Creek Range, just east of Ely in the Egan Range, what is perhaps the Silurian Enreka quartzite appears, forming the crest of a minor ridge, flanking to the west the main Schell Creek Range. The quartzite dips to the west abont $30^{\circ}$ and is underlain by what appears to be the Pogonip formation. No fossils were collected.

The Silurian rocks above described are probably cnt off to the south by an east-west fault, for they are succeded by Devonian strata.

Mr. F. B. Weeks ${ }^{e}$ found, in 1900, that, about 10 miles north of the roar leading from Osceola to Ely, the Cambrian beds on the northeast are separated from Ordovician beds on the southwest by a heavy fanlt. In these Ordovician beds the following fossils, determined by Professor Ulrich, were collected:

Orthis (related to O. bellarugosa):

Dalmanella (near perveta).

Dalmanella (near emacerata).

Modiolodon sp. nndet.

Ischyrodonta sp. undet.

Cyrtodonta? sp. undet.

Maclurea (cf. subannulata Walcott).

Gyronema (near semicarinatum).

Metoptoma sp. midet.

Endoceras (1).

Endoceras (2).

Leperditia (near fabnlites).

Leperditella.

Leperditella (with ventral swelling).

Sclımidtella n. sp. (near crassimarginata).

Aparchites sp. mudet.

Olemns? sp. nndet. (1).

Olemns : sp. nndet. ( 2$)$.

Asaphns.

Pygidium. sp. nndet. 
Another lot was as follows:

Asaphus (related to Megalaspis belemmurus White).

Two species of trilobites related to Symphysurus goldfussi Walcott.

Leperditella (related to L. inflata).

Undet. ostracod (? related to Octonaria).

Silurian rocks do not appear, so far as yet observed, until the neighborhood of Bristol, where the Eureka quartzite was observed by Mr. Walcott. The writer also has observed probable Silurian rocks, constituting low hills, which connect the Highland Range, in the neighborhood of Bristol, with the irregular ridges lying between the Egan and Pahroc ranges.

Farther south Mr. Walcott ${ }^{a}$ has noted the Eureka quartzite on the west side of the Highland Range, in a hill north of the road leading from Bennetts Spring to Hiko. At this point fossils are very abundant.

\section{DEVONIAN.}

At the western base of the Highland Range, at Stampede Gap, highly fossiliferous strata were observed, probably separated from the Cambrian strata which form the mass of the range by a heavy northsouth fault. No fossils were collected, but from the stratigraphy it seems possible that these are the continuation of rocks in the neighborhood of Coyote Spring, at the northern end of the Pahroc Range, just west from Stampede Gap, which are Devonian.

On the western side of the range, north of the road which crosses it between Ely and Osceola, the writer found dark-blue to gray-blue, often shaly limestone filled with calcite seams. From one horizon in this limestone he collected the following Deronian fossils, which were determined by Dr. George II. Girty: Stromatoporoid coral, Spirifer utahensis, and Ambocolia umbonata.

These Devonian strata are apparently separated from Silurian and Cambrian rocks farther north by an east-west fault.

\section{CARBONIFEROUS.}

The western half of the Schell Creek Range, where it was crossed on the road between Ely and Osceola, abont 20 miles southeast of Ely, is chiefly composed of Carboniferous rocks. They consist mostly of dark-blue, gray-blue, and often shaly limestones, with occasional brown quartzite seams. Some of the beds are semicrystalline. The series thronghout is highly fossiliferous.

Just after the road enters the range Upper Carboniferous fossils were collected. They wore determined by Dr. George II. Girty, as follows: Zaphrentis sp., Productus sp., Spirifer rockymontanus, Seminuta sp. 
A mile east of the above-mentioned locality the following Upper Carboniferous fossils were collected:

Orbiculoidea missouriensis.

Productus inflatus?

Marginifera muricata.

Cleiothyris orbicnlaris.

Seminnla subtilita.

Rhombopora lepidodendroides.

All these Carboniferous rocks dip to the east $20^{\circ}$ or $30^{\circ}$, and apparently abut directly against the Cambrian on the east.

Near the northern end of the Highland Range, 3 or 4 miles south of Patterson, Mr. Howell a has noted 2,000 feet of limestone containing well-marked Carboniferous fossils.

IGNEOUS ROCKS.

LATAS.

In the vicinity of Schellbourne the whole eastern part of the Schell Creek Range is corered by basic lava, and this also overflows to the western part of the range, covering np in patches the stratified Cambrian rocks. This lava is in general a pyroxene-alentite. Aceording to Mr. Emmons, ${ }^{\partial}$ the extreme northern portion of the range is entirely covered by rhyolite. In the vicinity of Schellbourne the writer found, underlying the basic lava, a few feet of white biotite-rhyolite.

On the western side of the Highland Range, 5 or 6 miles sonth of its northern end, Mr. Howell c has reported lava. Still farther south, at Stampede Gap, the writer observed a small area of rhyolite in the valley at the western base of the mountain.

DIKES.

Mr. Gilbert ${ }^{d}$ has noted in Ruby Hill Canyon, a few miles south of Sehellbourne, siliceous dikes cutting the Cambrian limestones.

STRUCTURE.

FOLDING.

On the west side of Schell Creek Range, just east of Ely, a conspicnous anticline was observed, trending parallel to the crest of the main range. The axis of this anticline is occupied by a valley, and the western limb is marked by a minor north-sonth ridge rumning from about the latitude of Ely northward to the neighborhood of Schellbourue. The rocks exposed in this anticlinal fold are probably Silurian. To the sonth the fold, and at the same time the ridge in which 
its western limb is exhibited, are apparently ent off by an east-west fanlt, while on the north the rocks of the fold pass under the Pleistocene valley detritus. About 10 miles sonth of the southern end of the minor ridges above mentioned what appears to be the continuation of the same anticlinal fold is exhibited in the foothills on the west side of the range. Still farther south the general strike of the rocks ehanges from south to southwest, and this anticlinal fold probably passes over into the southern end of the Egan Range, where-a series of folds was observed, one of which is perhaps identical with it. Farther south again there is probably another synclinal fold, which also passes over into the Egan Range on account of its southwesterly strike. This is probably followed by an anticlinal fold, such as Howell "has described, at the extreme sonthern end of the range, where the roeks dip east-southeast. Still farther south the several folds which are found in the ridges forming the southern extremity of the Egan Range are probably continuous across the intervening valley to the Highland Range.

The Cambrian rocks, which form the greater part of the eastern portion of the Schell Creek and IIighland ranges, are also folded. At Schellbourne the rocks seemed to the writer to dip in general to, the east, although the attitude conld not be certainly made out. Farther south, at Whites Peak, Mr. Gilbert ${ }^{b}$ found the Cambrian rocks dipping to the west at an angle of about $20^{\circ}$. Still farther south, where the writer observed the Cambrian rocks in crossing the range between Ely and Osceola, he found the folding complicated and the faulting considerable.

In the Highland Range the folds in the Cambrian rocks appear to be gentle and of no great extent. Those that were observed were mostly transverse to the range, and in general the disposition of the horizons did not vary greatly from what they would have been had they been horizontal.

\section{FAULTING.}

Although no careful examination has been made, the stratigraphy indicates the existence of important faults in the Schell Creek and Highland ranges. These probably belong to two chief systems-one north and south and one east and west. On the road which crosses the Schell Creek Range between Ely in the Egan Range and Osceola in the Snake Range the whole rock series dips to the east. The easteru half of the range is composed of Upper Carboniferous limestones carrying abundant fossils, while the western is composed of metamorphic limestones underlain by schistose mica-slates. The character of these later rocks, together with the succession, enables one to correlate them with the Cambrian rocks found in the same range just north of 
here and also in the Highland and Snake ranges. This implies either an enormous fault or a great erosion gap.

Opposite Stampede Gap the writer crossed the valley which lies on the west of the range from a district where there are abundant exposures of fossiliferous Deronian and Silurian rocks. At the western base of the range he noted in the foothills fossiliferons strata, apparently belonging to the same series, from which, however, he collected no fossil remains. Proceeding farther west he found the whole mountain made up of altered massive limestones, with intercalated shales and schistose slates, whieh belong to the Cambrian. A few miles north of Stampede Gap, at Bristol, Mr. Waleott found the Eureka quartzite of the Silurian at the westem base of the mountains, and the same formation about 15 miles sonth of Stampede Gap on the road from Bennetts Spring to Hiko. Both these places oecupy the same relative position at the western base of the range. Between these Silurian foothills and the Cambrian roeks of the main range there appear's to be a great break, bringing about juxtaposition of strata which in their normal stratigraphie suceession are separated by nearly 2 miles of intervening sediments. This is believed to be the same break as that previously noted farther north, and it may be either a fault or an erosion gap.

An east-west fault appears to eut the range transversely at a point about 10 miles southeast of Ely in the Egan Range. To the north of this line is an antielinal fold whieh exposes probable Silurian or Cambrian roeks. To the south only the eastern limb of the fold is found, the ridge which represents the western limb being ent off. On the south side the rocks carry Devonian fossils.

About 10 miles north of the road which erosses the range between Osceola and Ely Mr. F. B. Weeks ${ }^{a}$ observed, in 1900, a strong northwest fault marked by a profound interior valley. Cambrian roeks on the northeast side of the fault are brought against Ordovician strata on the north. The fault euts aeross the entire range.

$\mathrm{Mr}$. Howell ${ }^{b}$ noted a probable eross fault near the north end of the Highland Range. The line of this fault is eontinuous with a probable fault line sketehed by the writer on the Egan Range, just to the west. The writer also saw, a few miles north of this, what is perhaps a parallel east-west fault, marked by a deep transverse valley in the Egan Range and extending across to the gap which separates the Sehell Creek Range from the Highland Range. The displacement of these faults was not measured, but is probably very eonsiderable.

At Pioche there are a number of intersecting faults, some belonging to a northwest-southeast system and some to a northeast-southwest system. The main fault observed by the writer runs through the south end of the town, in a northwest direction. It is nrarked by a 
deep gulch, and has the Cambrian quartzite on the northeast side and the Cambrian shale and limestone on the south. This fault has at least 1,000 feet of rertical separation and may have much more. Other faults are parallel to this, and there are a number of northeastsouthwest eross faults with considerable displacement. The effect of these is to cause a certain degree of checkering of quartzite and limestone. The northeast gulch in which Pioche lies seems to mark one of these faults. ${ }^{a}$

\section{EGAN RANGE.}

The Egan Range is the next important range west of the Schell Creek and IIighland ranges. Its north end lies just north of the fortieth parallel and is included in the maps of the Fortieth Parallel Survey. It extends due south ward nearly 150 miles.

TOPOGRAPHY.

: Throughout nearly its whole course the Egan Range consists of a single well-defined central ridge, from which the slopes to the valley on both sides are comparatively steep. In the neighborhood of Ely the ridges are slightly broken np, but this is apparently due largely to the presence of igneous rocks. At the extreme south end, also, the main range splits up into several low ridges.

The range is cut through at intervals by transverse valleys connecting the valleys on either side of the range and very little higher than they. Such valleys are found at Egan Canyon and at Ely. Near the southern end of the range there are other deep transverse gaps, which, however, do not cut clear down to the level of the valleys.

\section{ARCHEAN ROCKS.}

Mr. S. F. Emmons ${ }^{b}$ has described the rocks in an outlying ridge on the east side of the range, just south of the eastern end of Egan Canyon. Here the lowest formation exposed is a mica-granite, which is overlain by quartzites and quartzitic schists referred to the Cambrian. The granite is referred to the Archean.

SEDIMENTARY ROCKS.

CAMBRIAN.

As above noted, Mr. Emmons found overlying the granite at the eastern end of Egan Canyon sereral thousand feet of quartzites and quartzitic schists, together with a 50-foot bed of argillite. These quartzites are overlain by limestones.

The same locality was observed by the writer from a distance, and on account of the stratigraphy was referred with little hesitation to

a These observations are in accordance with those previously made by Mr. Howell (U.S. Geog. Surv. W. One Hundreth Mer., Vol. III, pp. 257-261), as the writer discovered since writing the above.

$b$ U. S. Geol. Expl. Fortieth Par., Vol. II, p. 488. 
the Cambrian. The rocks were not visited, but at the base are heavy beds dipping to the west at an angle of abont $30^{\circ}$ and striking north and south. These massive beds resemble the Cambrian quartzite and limestone, while above them come more easily eroded limestones, which eorrespond in thickness and position to the Silurian Pogonip formation. Above the Pogonip on the east face of the main ridge (which is separated from the spur above mentioned by a trough of erosion) is exposed the Eureka quartzite, which is traceable along the range for several miles northward. The identification of this Silurian makes the reference of the easterly roeks of the outlying spur to the Cambrian safe.

Mr. F. B. Weeks " reports that in the summit of the range, about 10 to 12 miles south of Egan Canyon, the following Upper Cambrian fossils, determined by $\mathrm{Mr}$. Walcott, were collected:

Obolus (Lingulella) discoidensis H. \& W.

Obolus (Lingulella) manticulus White.

Obolus (Lingulella) punctatus Walcott.

Ophileta?

Agnostus, 2 sp.

Ptychoparia, 2 sp.

Along the southern part of the Egan Range the west face, which eonfronts the southern part of Sierra Valley, exposes some magnificent sections of strata. These also were not visited any farther north than the vieinity cf Adlams's ranch on White River, near which point they were found to be Devonian. Farther north, however, a thick section of roeks, striking northeast and dipping southeast at an average angle of $30^{\circ}$, was exposed, and the circumstance that the strike is diagonal to the north-sonth face of the range brings it about that progressively lower beds are exposed going north. About 2 miles north of the vieinity of Butterfield Spring what was taken to be Enreka quartzite was seen at a distance; below this oeeurs a great thickness of more easily eroded limestones, which were referred to the Pogonip formation; and beneath these again massive limestones, which perhaps represent the Upper Cambrian. Only a comparatively slight thiekness of the latter limestones is exposed, when the dip of the seetion is reversed and becomes northwest, so that the section begins to ascend toward the north.

SILURIAN.

Mr. Emmons ${ }^{b}$ noted the finding of Silurian fossils in the limestone in the neighborhood of Egan Canyon. The writer, who crossed the range at this point from Cherry Creek westerly, did not succeed in finding any good fossils, but identified the formations on lithologic and stratigraphic grounds as notably belonging to the Pogonip, the 
Eureka, and the Lone Mountain formations of the Silurian as exhibited in the Eureka section. In the easterly spur of the mountains just south of Egan Canyon, as above noted, the whole thickness of the Pogonip strata is exposed, oceupying a valley of erosion between this spur and the main ridge. On the easterly face of the main ridge the Eureka quartzite is exposed, and may be traced across Cherry Creek and still farther north. Above the quartzite, in ascending from Cherry Creek westerly, dark-blue erystalline limestones, similar lithologically to the Lone Mountain limestones of Eureka, and carrying indistinct fossils, were observed.

The probable exposure of the Eureka quartzite on the western face of the range, near its sonthern end, has already been noted in connection with the probable Cambrian exposures. It is probable that along here not only the Eureka quartzite, but the whole Silurian section, is exposed.

Crossing the separate low ridges which constitute the comnection between the southern end of the Egan Range and the Palnoc Range, what is almost certainly the Eureka quartzite was found about 25 miles northwest of Pioche. Here was found a white vitreous quartzite, rather coarse grained and upward of 100 feet thick, above which lie dark-gray, comparatively thin fetid erystalline limestones, with the fossils too much altered to be recognizable. This is perhaps the Lone Mountain limestone. These Silurian rocks are exposed only along the eroded axis of an east-west anticline, and to the north and south are overlying rocks from which Devonian fossils were collected. The general structure of the beds at this point makes it probable that a little farther northeast a greater thickness of Silurian rocks is exposed, in the valley midway between this point and the Highland Range.

\section{DEVONIAN.}

The western face of the Egan Range about 8 or 10 miles north of Cherry Creek is composed of stratified rocks dipping very gently northwest. These stratified rocks are limestones whose appearance suggests the Nevada formation of the Devonian. A short distance north of these, also on the west face of the range, black, shaly, fetid limestones carrying Upper Carboniferous fossils were obtained, while sonth of the supposed Deronian rocks, in the neighborhood of Cherry Creek, there are exposed Silurian formations, as already mentioned. It is more than probable, therefore, that the intervening rocks are really Devonian. $\mathrm{Hr}$ : Emmons has made the same suggestion. ${ }^{a}$

In the canyon which ents through the range at Ely limestones carrying Lower Carboniferous fossils were found. In these limestones are siliceous beds which may perhaps represent the Diamond Peak quartzite of the Eureka section, beneath which there is a slight 
exposure of shaly limestone which may represent the White Pine formation. No fossils, however, were procured from these beds, and their identification as Devonian is only provisional.

At the northern end of the curving spur which joins the main range near this point (Pl. V, A), where it passes under andesitic flows just south of Summit stage station Cyathophyllum sp. was found, and was referred to the Devonian by Dr. George H. Girty.

This Devonian area, however, is small, since at a distance of 2 miles farther south similar limestones carrying Carboniferous fossils were found.

Devonian rocks make up nearly the whole of the series of low ridges which constitute the extreme southern end of the Egan Range, so far as these rocks were examined by the writer in crossing diagonally from northwest to southeast. In crossing the pass which euts through the western and main ridge of these mountains, about 10 miles due southeast from Adams's ranch, comparatively thin-bedded fetid limestones were found folded into a syncline striking diagonally to the trend of the pass, and carrying the following Devonian fossils, as determined by Dr. George II. Girty:

Amphipora? sp.

Cladopora? sp.

Stromatoporoid coral.

Chonetes macrostriatus.

Spirifer utahensis.

The corals obtained here make up the greater bulk of the rock, which appears, therefore, to have been a Paleozoic coral reef. Both the fossils and the nature of the inclosing rocks are identical with the fossils and rocks found in the Golden Gate Range, directly west of here and about 15 miles distant.

Following the road from here sontheastward to Pioche, Devonian fossils were again obtained about 12 miles south of the first locality, as follows:

Amphipora? sp.

Stromatoporoid corals.

Spirifer maia (small variety).

Again abont 6 miles farther southeast the following Devonian fossils were collected:

Fucoid.

Productella subaculeata.

Rhipidomella sp.

Spirifer disjunctus.

Spirifer utahensis.

Spirifer strigosus?

Ambocœelia umbonata.

Camarotøechia sappho.

Modiomorpha obtusa?

Grammysia minor?

Loxonema? sp. 

The structure of the surrounding ridges makes it probable that most of them are Devonian.

\section{CARBONIFEROUS.}

In the extreme northern end of the Egan Range Mr. Emmons ${ }^{a}$ collected probable Carboniferous fossils. On the western front, abont 12 miles north of Cherry Creek, the following fossils were collected by the writer and identified by Dr. Girty:

Orbiculoidea missouriensis?

Marginifera splendens?

Productus n. sp.

Spirorbis sp.

Euomphalus catillotdes.

Between Egan Canyon and Ely it is probable that the Carboniferous rocks eover a considerable area. Near Ely, Carboniferous limestones are abundantly exposed. Abont 2 miles sonth of Summit Springs, on the road between Ely and Hamilton, massive semicrystalline limestones are found which earry a probably Upper Carboniferous fossil that was determined by Dr. Girty as Zaphrentis sp.

About 6 miles east of here, on the east side of the narrow valley separating the minor ridge, in which the above fossil was obtained, from the main range, were collected the following Upper Carboniferous fossils:

\section{Seminula stibtilita?}

Lithostrotion? sp.

Fusulina cylindrica.

Two miles southeast of the last-named locality, near the western entrance of the canyon which ents through the range at Ely, darkgray carbonaceous fetid limestones were found which carry the following Lower Carboniferous fossils:

\section{Zaphrentis sp. \\ Orthothetes inæqualis. \\ Rhipidomella michelini. \\ Productus semireticulatus var. \\ Productus n. sp. \\ Spirifer centronatus. \\ Straparollus luxns. \\ Prœtus peroccidens.}

The black shaly limestone which carries the Lower Carboniferous fauna at the last-named locality passes into a belt of red, yellow, and orange weathering shales, with occasional beds of gray, shaly limestone. The thickness of these shales is estimated at from 800 to 1,000 feet. Farther east in the canyon beds of cherty and siliceons limestones also occur in this same series. It is probable that the lowest of these shaly beds are Devonian, but to the south of Ely, above 
the shales, the more massive limestone comes in above again and extends for 5 or 6 miles at least, striking east and west and dipping gently south.

On the southeastern slope of Hamels Peak, some miles south of Ely, the fossils named below were collected by Mr. F. B. Weeks, ${ }^{a}$ and were determined by Dr. Girty. Regarding this collection, Mr. Girty states "The fauna has a similar facies to that of the Marion formation of the Kansas section, which Prosser regards as a true Permian fauna, and it probably can be safely correlated with the Marion."

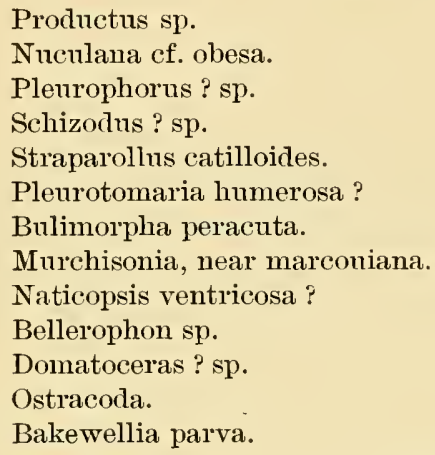

IGNEOUS ROCKS.

LAVAS.

On the west side of the Egan Range, just north of Egan Canyon, a series of low hills are composed of basalt. One of these hills has a conical shape practically unmodified, and, from the eircumstance of this slight erosion, the age of the lava must be very recent.

Farther sonth, also on the west side of the range, is a considerable mass of volcanic rock which has filled up the valley between the southern end of the Long Valley Range and the Egan Range north of Ely. This is, in general, a dacite-andesite and has been deeply eroded, indicating greater age for it than for the basalt.

At the southern end of the range, in the separate low ridges which form the connection of this range with the Pahroc Range, there are large areas of quartz-latite which seem to be continnous with similar lavas oceurring in the northern end of the Golden Gate Range and on the easterly side of the Grant Range in the same latitude. As in the other cases described, it is plain that these outflows occurred subsequent to the formation of the deep valleys between the limestone ridges, for the volcanic rock either fills up such valleys or has been poured into them without quite filling them up and now forms their floor. Nevertheless, this rolcanic rock is also deeply eroded, and therefore its age is not recent. It may be considered as very late Tertiary or early Pleistocene. 
DIKES.

At the western entrance of the canyou which cuts throngh the range at Ely a dike of hornblende-tonalite-porphyry was noted. Farther east in the canyon oceur a number of other siliceous dikes. These dikes probably connect with a larger body farther south, which seems to form the crest of the range in the vicinity of Howells Peak.

Just west of the town of Cherry Creek occur a number of dikes which are apparently connected with a larger igneous body a little farther north. Specimens of these dikes show them to be chiefly quartz-monzonites.

\section{STRUCTURE.}

FOLDING.

The extreme northern end of the range is said by Mr. Emmons ${ }^{a}$ to present an anticlinal fold striking northeasterly, and so diverging from the general trend of the mountains. Farther south, but still north of Egan Canyon, the general structure is plainly synclinal, and has the same northeasterly trend. This syncline must succeed the anticline to the southeast. In the ricinity of Egan Canyon, on the easter'n side of the range, the strata on the eastern limb of this syncline dip to the west at angles of from $30^{\circ}$ to $45^{\circ}$, which gradually grow less to the west until, at a point about 8 or 10 miles north of Cherry Creek, and on the west side of the range, easterly dipping strata constituting the other side of the syncline are found.

Between the Cambrian rocks on the eastern side of Egan Canyon and the same formations on the west face of the Schell Creek Range, only a few miles to the east, there is probably an anticlinal fold occupying Steptoe Valley.

From Egan Canyon south the Egan Range may be seen to consist of stratified rocks as far as Ely, but the general northeasterly trend of the beds at Egan Canyon changes to a northwesterly one in the mountains north of Herenles Gate, about 10 miles north of Ely. The general structure of the mountains at this point seems to be synclinal, the western limb of the fold being exposed in the Devonian limestone lying just south of Summit stage station on the road between Ely and Hamilton. These limestones dip to the east at an angle of $20^{\circ}$.

From Ely south for a number of miles the strata are not conspicuously folded, but dip gently in various directions, chiefly to the south. The whole southern end of the range, however, from a point about 10 or 15 miles south of Ely as far as the point where the main range begins to split up into several, shows beds which strike uniformly northeast, at an angle with the general north-sonth trend of the mountains. The farther south one goes the more easterly becomes the strike of the strata, until, in the series of low ridges at the south- 
ern end of the range, it swings around to east-west and then to southeast, and so runs into the Pahroc Range, where it becomes due north and south.

In this sonthern part of the range many parallel open folds are exposed. On the west face, abont 30 miles north of Adams's ranch, in Sierra Valley, the axis of a broad syncline may be traced, with the rocks on both sides dipping from $10^{\circ}$ to $30^{\circ}$. This is followed to the south by a slight anticline and this by a broad syncline, whose axis ents the mountains about 10 miles southeast of Adams's ranch, at the pass through which runs the road to Pioche. South of here the sueceeding anticlines and synchines are frequent and regular. Since their strike is transverse in general to the trend of the ridges and since different ridges are composed of the same rocks, the folds may be traced from one to the other for long distances. Thus, sonth of the synclinal fold above described a broad anticline was observed, which comprises the rocks for a distance of about 10 miles to the sonth and which has in general an east-west trend. South of this a comparatively narrow syncline exists, and south of this again an antichinal fold, which after swinging from an east-west to a southeasterly direction, appears to change still more, till it enters the Pahroc Iange with a north-south trend and constitntes the chief fold of these mountains.

In general, therefore, the Egan Range consists of open and symmetrical anticlines and synclines, with the rocks rarely dipping more than $30^{\circ}$. In general these folds trend more easterly than the general trend of the mountains, and thus a number of succeeding folds are exposed.

FAUTiTING.

In the southern part of the range several deep transverse valleys suggest fault lines, but the examination was too hasty to be sure of their existence.

ORES.

At Mineral City, just west of Ely, lead, silver, and gold, with some copper, are obtained. At this locality a number of siliceous dikes cut up through the limestone, and seem to be connected with the mineralization. In the neighborhoot of Ely there are considerable ore deposits. At Cherry Creek also the dikes have perhaps brought about the deposition of the minerals. Some of the ore deposits here run comparatively high in gold and silver.

\section{LONG VALLEY RANGE.}

Long Valley Range consists of low limestone mountains. Its southern end, just east of IIamilton, is united with the White Pine Range by a series of connecting north-sonth parallel ridges. On the north it exterds up into the area of the Fortieth Parallel surveys, where it is represented by a series of detached low limestone mountains and finally dies ont in the valley. 


\section{TOPOGRAPHY.}

The Long Valley Range consists in general of a single main ridge, on both sicles of which the ascent from the base is comparatively gentle. The interrupted form of the northern end of the range, resulting in detached elumps of hills, has probably been brought about by erosion, which has cut deep into the ridge and formed valleys which were afterwards filled up with detrital material, on a level with that of the main valleys between the ranges. On the eastern side of the sonth end of the range a great flood of andesitic lava has filled a former valley to a height equal in general to that of the preexisting ridges.

This andesite itself has been considerably eroded. The valleys which have been cut in it, being younger than the main valley into which the lava was poured, are instrictive as to the manner of the formation of desert valleys in general and their filling up with detrital accumulations. Each of these narrow valleys in the lava, often only a few hundred feet wide, presents in a small way all the characteristries of the larger valleys which separate the ranges. In the middle is a flat sage-brush plain, and on the sides long gentle slopes of wash proceed from the gullies which cut up the adjoining ridges. In these deposits of the smaller valleys, as in those of the larger valley, there is no trace of deposition in the presence of water, but the valleys have filled up evenly and smoothly with dry material, distributed perhaps in part by rivulets and by wind storms.

\section{SEDIMENTARY ROCKS.}

\section{CARBONIFEROUS.}

At the south end of the range a section was followed along a portion of the road between Hamilton and Ely. The rock here is a limestone, often cherty or aphanitic. Under the microscope the ehert shows cross sections of organic forms. The western edge of the section yielded the following Upper Carboniferous fossils, which were determined by Dr. Girty:

\section{Marginifera muricata?}

Productus prattenianus.

Productus inflatus?

Farther east the following Upper Carboniferous fossils were collected from the same limestone at a horizon several hundred feet higher than the above:

Fenestella? sp.

Campophyllum torquium?

Productus prattenianus.

Fusulina cylindrica.

Rhombopora lepidodendroides.

Fistulipora? sp.

Productus semireticulatus. 
Only about 1,000 feet of strata are exposed in this section, owing tio the low dip of the rocks.

On the north end of the range the separated groups of low mountains above mentioned appear to be almost entirely composed of Carboniferous limestone. They are so shown on the maps of the Fortieth Parallel Survey. The writer collected two lots of Upper Carboniferous fossils at the northern end of the limestone mountain which lies just east of Franklin Lake and the northern end of Ruby Lake. This is pracically the northern terminus of the Long Valley Range, although in the Fortieth Parallel maps it is given under the head of the Ruby Group of Mountains.

According to Dr. Girty's determination, the first locality yielded Marginifera splendens?

The second locality afforded the following:

Chonetes flemingi.

Productus subhorridus.

Productus multistriatus.

Spirifer cameratus?

spiriferina pulchra.

Seminula mira.

Sonth of the lava area which fills the valley between the Long Valley Range and the Egan Range, on the road from Hamilton to Ely, there is a narrow spur of momntains rumning from the neighborhood of Summit stage station to the Egan Range, south of Ely. This may be considered as an outlying spur of the Egan Range, but yet may extend beneatl the lava and so form a connection with the Long Valley Range. From the rocks of this spur at a point just south of Summit station a Devonian coral was obtained. Farther south in the same ridge are Carboniferons fossils, as described under the head of the Egan Range (see p. 51).

\section{IGNEOU'S ROCKS.}

LATAS.

The great mass of lava which flanks the eastern side of th' Long Valley Range proper at its lower end has already been mentioned. The extent of this patch of lava to the north is nncertain, but probably is not more than 10 or 15 miles. To the south it passes under the Pleistocene accumulations of Sierra Valley, while to the east and to the west it abuts against the limestones of the Egan and the Long Valley ranges. As noted above, this lava has been considerably eroded. Thin sections of the rock show it to be in general a daciteandesite, the prevalent type being a dacite containing augite, biotite, and hornblende.

\section{STRUCTURE.}

FOLDTNG.

A section taken at the southern end of the range shows a monoclinal structure for the main ridge. In reality, however, this is the 
east side of an anticline whose axis lies in a narrow valley to the west of the main ridge and whose easterly limb is exposed in the next ridge to the west (see fig: 1, p. 66).

The spur of Deronian-Carboniferous rocks described on page 56 is separated from the main ridge by Pleistocene deposits and by lava, and the structural connection is not shown, but in itself it exhibits a series of somewhat closely compressed regular open folds with northsouth strike, changing to a northwest-southeast strike as the spur approaches the Egan Range. In this minor ridge there is exposed, beginning with the most westerly fold, an anticline, a syncline, a second anticline, and a second syncline.

For the main ridge of the Long Valley Range the general strike is seen to be parallel to the general trend of the momntains; that is, a little east of north. At the north end of the range, at the fossil localities, a slight syncline with a general north-south strike was observed in the Carboniferous limestone.

\section{GOLDEN GATE RANGE.}

The Golden Gate Range scarcely deserves a separate name, on account of its comparative insignificance. This name is applied to a connected series of low monntains which lies to the east of the Grant Range, and properly has a north-south extent of not more than 25 miles, with an average width of 3 or 4 miles. On the south the Golden Gate Range is connected by low hills with the northern extension of the Hiko Range, while on the north the range dies away into the Sierra ralley. Twenty-five miles north of the north end of the range there is a chain of low hills running north and south and lying midway between the Thite Pine Range and the Egan Range. These hills might perhaps be considered as the northern continuation of the Golden Gate Range, the intervening portion being covered up by the Pleistocene accumulations of Sierra Valley.

\section{TOPOGRAPHY.}

The mountains which make up the Golden Gate Range are enturely detached from one another, and are separated by narrow stretches of Pleistocene valley deposits, on a general level with the valleys on both sides of the range. The separate groups are sometimes composed of stratified rocks and sometimes of lava. The hills of stratified rock are scarped along the axes of anticlinal folds. They are therefore scarped on both sides when they are synclinal, while when they are anticlinal they have in general smooth sides with a sharp downentting in the center. The groups which are composed of rolcanic rocks hare naturally a milder and more miform topography.

SEDIMENTARY ROCKS.

SILURIAN.

An isolated butte at the northern end of the Golden Gate Range, not very far from Adams's ranch on White River, exposes a rery inter- 
esting section of Silurian rocks. The beds here strike $\mathrm{N}$. $35^{\circ} \mathrm{W}$. and dip $30^{\circ}$ NE. At the base of the section is 300 feet of thin-bedded, somewhat fetid limestone and limy shale. Above comes 250 feet of white vitreous quartzite, which is undoubtedly the Eureka formation. Above this comes about 800 feet of comparatively massive brownish limestone (the Lone Mountain formation). At a point about 150 feet below the bottom of the Eureka quartzite, in the Pogonip limestone, Ordorician fossils were found. They have been determined by Dr. Girty as follows:

Orthis perveta.

Maclurea $\mathrm{sp.}$

Murchisonia sp.

Plenrotomaria sp.

Leperditia bivia.

Illaenus sp.

Trilobites undet.

DETONIAN.

Sonthwest from this butte and about 10 miles distant is a considerable clump of hills, which forms one of the chief features of the range. A section of abont 2,000 feet of limestone is here exposed. The lower 1,000 feet is of limestone, which in places has the peculiarity of weathering brown and craggy, like quartzite. The upper 1,000 feet is composed of shale and thin-bedded limestone. In the lower limestone, where it was examined, the rocks are chiefly composed of corals and constitute, therefore, part of a Devonian coral reef. The same reef, with the same corals, was found in the ridges which form the southern continuation of the Egan Range, $12 \mathrm{or}^{\mathrm{r}} 15$ miles east of here. The following Devonian fossils were identified by Dr. Girty:

Amphipora? sp.

Stromatoporoid coral.

Indeterminable gasteropod.

PLEISTOCENE.

As before noted, the hills of the Golden Gate Range are surrounded and often separated by accumulations of Pleistocene material. This material is generally angular and bears the marks of having been brought to its present position by the influence of rains, wind, and gravity, not by stream or lake action. Probably this Pleistocene forms a veneer over underlying Tertiary deposits, as is the case in the next valley to the west-Railroad Valley.

In the neighborhood of the Silurian butte above mentioned is an extensive deposit of calcareous hot spring tufa, covering apparently an area of several square miles and eroded into hills and bluffs in places 40 feet high. Within this area active hot springs are plentiful.

IGNEOUS ROCKS.

Several of the aminences of the Golden Gate Range are composed of volcanic rocks, which also surround some of the hills of stratified 
rocks and apparently extend to the east to the sonthern end of the Egan Range, as represented on the map. A specimen of the lava from the north end of the Golden Gate Range proved to be quartz-latite.

\section{STRUCTURE.}

\section{FOLDING.}

In the stratified rocks of the Golden Gate Range the strike runs diagonally or transversely to the general trend of the mountains. It has been noted how in the sonthern part of the Schell Creek and Egan ranges the folds have northeast and southwest axes, which are diagonal to the general trend of these ranges. In the Pahroc Range the trend of the axes of folding seems to be north and sonth, parallel with the mountains. Between the Pahroc and the Egan ranges there is an area containing a number of minor cross folds, which have a curving axis and which extend to and connect with the folds of the Golden Gate Range. Sereral of these minor folds seem to die out just west of the Golden Gate Range.

The anticlinal fold which marks the rocks of the northernmost and chief group of hills of the range in which the Devonian corals were found may be a continuation of a possible broader anticlinal axis running between the Worthington Mountains and the northern end of the Hiko Range. The folds of the Golden Gate Range lying south of this anticline, comprising two more anticlines with intervening synclines, do not have any visible relation to the folds to the west or south. However, they may be traced continuously to the east across the several ridges which mark the southern end of the Egan Range. The southernmost folds eurve around southeasterly toward the Pahroc Range, while the northerly ones, diverging from the others, maintain a northeasterly direction.

\section{FAULTING.}

In the neighborhood of the Silurian butte above mentioned the abundance of hot springs suggests the presence of faults, but this could not be established.

\section{HUMBOLDT RANGE.}

The Humboldt Range is the most important mountain ridge in the Great Basin between the Wasatch and the Sierra Nevada. Its southern end only was visited by the writer, and as this has already been mapped and explored by the geologists of the Fortieth Parallel Survey, it is unnecessary here to go into details. But inasmuch as the writer collected fossils in localities from which none had been reported, it is thought advisable to insert this short deseription.

TOPOGRAPHY.

North of Fremont Pass the Humboldt Range is exceedingly rugged and precipitons. South of the pass the mountains become lower. 
At Hastings Pass they are of only moderate height, and the ascent from the base on both sides to the summit is not precipitous. South of Hastings Pass the mountains are still lower, and pass into straggling groups which connect with the northern extension of the White Pine Range.

\section{SEDTMENTARY ROCKS.}

North of Fremont Pass the Humboldt Range consists mainly of Archean rocks, as has been described by King ${ }^{a}$ and Hague. ${ }^{b}$ These rocks consist of a series of gneisses and schists overlying the basal granite and having a thickness of 8,000 or 10,000 feet. Of this series the lower 5,000 feet is in general a mica-gneiss, while the upper 5,000 feet is a hornblendic and dioritic schist, containing veins of quartzite. At the top are beds of limestone and quartzite. Above this gneiss and schist series comes a series of quartzites about 2,000 feet thick. The quartzites are white or yellow-brown in color and contain secondary garnet, hornblende, actinolite, muscovite, biotite, and iron oxide. On them rest unconformably the Paleozoic strata, with the Devonian generally at the base and the Carboniferous above.

King notes the resemblance of the quartzite series (which lies unconformably beneath the Paleozoic beds) to similar rocks in the Wasatch Mountains. It is possible also that the thick white and brown Cambrian quartzites exposed in the Snake Range, especially in the vicinity of Jeff Davis or Wheeler Peak, may be equivalents of the Humboldt quartzite.

Sonth of Fremont Pass the eastern face of the range is composed of easterly or southeasterly dipping limestones. At a point not more than 4 miles south of the pass the following Coal Measures fossils were collected by the writer from a butte at the base of the mountains. They were determined by Dr. Girty as follows:

Fistulipora sp.

Campophyllum torquium?

Lophophyllum proliferum.

Rhipidomella pecosi.

Productus sp.

Spirifer cameratus.

These same limestones continue all along the east face of the range as far as Hastings Pass. On the summit of the pass is found a considerable thickness of sandstones mixed with fine conglomerates. These the Fortieth Parallel geologists regarded as Deronian of the Ogden formation, which would correspond to the Diamond Peak quartzite of the Eureka section. A short distance west of the summit the Paleozoic rocks are overlain uneonformably by thick deposits belonging to the Humboldt Pliocene of the Fortieth Parallel Survey. At the upper edge of the Pliocene deposits the material consists of 
large angular fragments of limestone. From some of the largest of these fragments fossils were obtained which were determined by Professor Ulrich as Ordovician.

Leperditia bivia White.

Leperditia sp. (nevadensis:).

Rhynchonella?

Strophomena minor Walcott.

Strophomena? nemea H. \& IV.?

Dalmanella perveta? Walcott.

Bathyurns.

If Silurian rocks exist in place at this point one may well suppose that they are exposed by means of a fanlt, for otherwise the thickness of strata in the mountains seems hardly sufficient to account for their appearance.

\section{IGNEOUS ROCKS.}

North of Fremont Pass the basal rock appears to be mica-granite, as described by King. ${ }^{a}$ South of Hastings Pass a considerable area is also represented as granite in the Fortieth Parallel maps.

\section{STRUCTURE.}

FOLDING.

The general structure of the Humboldt Range is a broad anticline, as has been mentioned by King ${ }^{b}$ and by Hague, ${ }^{c}$ and as can be seen by an inspection of the maps of the Fortieth Parallel.

\section{FAULTING.}

It appeared to the writer that Fremont Pass is the line of an eastwest fault, and that this explains the abutting of the Paleozoic rocks on the south against the granite and Archean on the north. Noreover, the above-mentioned Paleozoic rocks are sharply turned up along this supposed fault line, so that they dip steeply, and their strike swings round from the normal north-south direction to a northeasterly one, so as to be nearly parallel with the supposed fault.

The possible existence of a fault along the west side of Hastings Pass exposing the Silurian rocks has been mentioned above.

\section{WHITE PINE RANGE.}

The White Pine Range, as here described, is the southern continuation of the Humboldt Range, and its northern end begins about 10 miles south of Hastings Pass, in that range. From this point it extends unbroken southward for 100 miles, with a general due northsouth trend. At its southern end it is continuous with the short Grant Range, which topographically and geologically is a part of it, but which is differently named and will be described separately. 
TOPOGRAPHY.

The northern part of the White Pine Range, from the sonthern end of the Humboldt Range to the IVhite Pine mining distriet, consists of a main ridge, which is narrow and not very high, with a number of minor ridges on each side, separated from the main ridge by narrow valleys in which the underlying rock is only partly obseured by Pleistocene detritus. In the vicinity of the White Pine mining district the mountains grow higher and the small north-sonth ridges change into a complicated group of irregular mountains. At the same time the main ridge broadens out to four or five times its former width.

In the White Pine mining district three man north-south ridges may be distinguished-that of Pogonip Monntain on the west, the minor one of 'Treasure Hill in the middle, and that of Mokeamoke Ridge on the east. Still farther east a succession of regular northsouth ridges, similar to those just described for the northern part of the range, form a continuation of the southern end of the Long Valley Range.

Within the White Pine mining district the momntains reach a height of 10,000 feet above the sea, while to the north and to the south they are considerably lower. To the south of the distriet also the mountains assume something of the same simple character as they do to the north, being made up of regular north-south ridges, and for the most part consisting of a single main ridge. While in the mining district the mountains and valleys are irregular, the topography of the range to the north and to the south is quite conventional, showing a uniform snceession of serrated peaks of nearly uniform height, with their sides furrowed at comparatively regular intervals by the drainage.

Within the mining district the irregularity is due, as will be presently seen, to the local complexity of the geologic structure. Pogonip Mountain, which, near Hamilton, juts boldly out from the main ridge and is the highest peak in the whole neighborhood, has a bold scarp to the north and to the west. Throughout the distriet there are a number of other precipitous cliffs. But in the rest of the range the mountains show the same steep, but yet not abrupt, faces that are characteristic of the other ranges of the region. It was noticed, however, that south of Hamilton the west face of the mountains was rather steeper than the eastern one.

SEDIMENTARY ROCKS.

CAMBRIAN.

Pogonip Mountain is composed of Paleozoic strata which dip in general toward the east, forming the western limb of the syncline whose eastern limb is exposed on the west side of Treasure Hill Ridge. 
On the western side of Pogonip Momntain Mr. Walcott ${ }^{\alpha}$ has determined from fossils the existence of the Cambrian Hamburg limestone of the Eureka section. Abont 800 feet of the Cambrian is exposed at this point.

\section{SILURIAN.}

Silurian rocks were described from Pogonip Monntain by Mr. Hague $^{b}$ during the Fortieth Parallel Survey. Later on the Silurian beds were also visited and reported upon by Mr. Walcott. ${ }^{c}$ Mr. Walcott found in Pogonip Mountain the following formations, divided according to the Eureka section:

\section{Section at Pogonip Mountain.}

Feet.

Lone Mountain limestone

1,450

Eureka quartzite

3.50

Pogonip limestone.

5,200

The writer obtained from Mr. Grandelmeyer, of IIamilton, a fossil said to come from a locality about 6 miles south of that place. It was identified by Dr. Girty as Receptaculites sp. and assigned to the Ordovician.

DEVONIAN.

While Pogonip Mountain is composed almost entirely of Silurian strata, the ridge next east is made up almost entirely of Deronian. Mr. Hague has described the strata and their contained fossils at this point. The formation, divided according to the Eureka section, comprises the Nevada limestones and the White Pine shales. Besides this Devonian ridge, the writer has also recognized the White Pine Devonian on the east side of Mokeamoke Ridge, where it is repeatedly brought to the surface beneatl the Carboniferous rocks by the erosion of anticlinal folds. He has moreover traced it north of the White Pine mining district for some distance along the west side of Mokeamoke Ridge, where it is largely hidden by Pleistocene detritus.

\section{CARBONIFEROUS.}

The third and most easterly of the three ridges at White Pine, Mokeamoke Ridge, is made up chiefly of Carboniferous rocks which carry abundant fossils. A list of Carboniferous fossils obtained from Mokeamoke Ridge in the mining district is given by Mr. Hague. ${ }^{d}$ The writer has traced the continuation of the Carboniferous belt of Mokeamoke Ridge 15 or 20 miles north of the mining district. At a

a Mon. U. S. Geol. Survey Vol. XX, p. 191.

$b$ U. S. Geol. Expl. Fortıetr Par., Vol. II, p. 542.

c Op. cit., p. 191.

d Op. cit., p. 547 . 
point 6 miles north of Iramilton Upper Carboniferons fossils were collected. The following were determined by Dr. Girty:

Productus semireticulatus?

Spirifer boonensis.

Seminula subtilita?

Enomphalus sp.

In the same rocks, close by the above locality, but at a horizon about 200 feet higher up, were found the following:

Productus prattenianns.

Productus sp.

Spirifer boonensis.

Seminula subtilita.

The minor parallel ridges which mark the northern end of the range have all the aspect and structure of the Carboniferons limestones. The writer has also found Upper Carboniferous limestones lying directly north of Pogonip Momntain, being separated from the Silnrian rocks at this point by a heavy east-west fault which determines the northern end of this mountain. Here the following fossils were collected:

\section{Lithostrotion? sp. \\ Productus sp. \\ Spirifer boonensis. \\ Spiriferina gonionotus. \\ Seminula mira? \\ Bulimorpha chrysalis?}

On the eastern side of Mokeamoke Ridge the writer has traced the Carboniferous rocks continuonsly across the intervening ranges to the southern end of the Long Valley- Range.

At the head of Allepaw (Applegarth?) Canyon, which is on the east sicle of the range, just east of Hamilton, Glyphioceras sp., an Upper Carboniferous form, was found.

Half a mile farther east, down the canyon, were found the following Upper Carboniferous fossils: Marginifera muricatas, Productus semireticulatus, Productus prattenianus.

Still half a mile farther, at the old pumping station for the town of Hamilton, were found: Orbiculoidea sp., Productus semireticulatus, Productus prattenianus, Marginifera muricata?

Along this section the Carboniferous rocks alternate with narrow belts of the underlying Devonian, which is exposed by the erosion of the anticlinal folds.

The Carboniferous section here has always at the base the Diamond Peak quartzite of the Eureka section. 'This quartzite, ol' rather sandstone (for it is not actually a (1uartzite), outcrops all along the western base of Mokeamoke Ridge, so far as this has been followed, and has a thickness of several hundred feet-much smaller than at Eureka. Above the sandstone come heavy, blue limestones containing Coal 
Measures fossils. In the Carboniferous hillocks at the northern base of Pogonip Monntain conglomerates were found containing pebbles of red and pmple chert, elosely resembling similar beds just west of here, on the east side of the Pancake Momntains.

RHYOLITE ASH.

North of the White Pine mining district and on the western side of Mokeamoke Ridge, the broad area of low hills is partly eovered by a deposit of stratified rhyolitic ash. Near sixmile IIouse, 6 miles north of Eureka, a dike of rhyolite is found whieh euts this deposit and shows that the ash is the earlier of the two. It is very likely that this rhyolite ash is of the same age as that exposed at Twin Springs in the Pancake Range.

\section{IGNEOUS ROCKS.}

\section{LAVA.}

The existence of a rhyolite dike in the vicinity of Sixmile House has just been referred to. In this neighborhood and farther north one finds, together with the rhyolite ash already described, numerous small buttes of lava which have been eroder into separate patches, but which once evidently were joined together to form a continuous thin sheet which spread over this region.

GRANITE.

Small patches of coarse-grained hornblende-granite have been mentioned by Hague ${ }^{t}$ as outeropping along the base of Pogonip Mountain. Whether this granite is intrusive or Arehean is not stated.

\section{STRUCTURE.}

\section{FOLDING.}

The main ridge, Mokeamoke, which extends north from the White Pine mining district, has a general synchinal structure. This syncline is rariously affected by erosion, so that at times one limb is almost completely worn away, giving the range the aspect of being monoclinal. For the most part, however, this syncline is well shown for a number of miles north of Hamilton. Still farther north, as far as the southern end of the Humboldt Range, the structure was not carefully observed, but in general it consists of a series of gentle open folds trending parallel to the mountain ridges. On Coal liurners or Bald Mountain the attitude of the strata seems to be very near horizontal.

Besides the main Mokeamoke Ridge, whose structure, as sketched about $S$ miles north of Hamilton, is shown in the acompanying figure 
(fig. 1), there are several minor parallel ridges. North of the White Pine mining district these minor ridges lie east of the main one, forming a continuous section which unites Mokeamoke Ridge with the

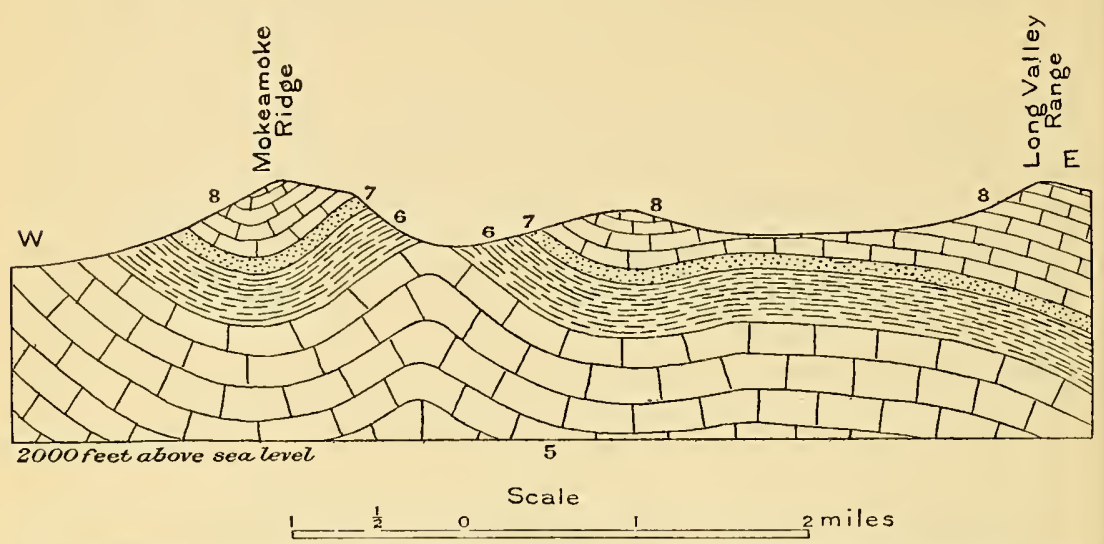

FIG. 1.-Sketch section 5 miles north of Hamilton across White Pine Range to the eastern edge of Long Valley Range. (For explanation of number's see fig. 2.)

southern end of the Long Valley Range. These ridges and the accompanying valleys (in whose bottoms the rock is very little obsenred by

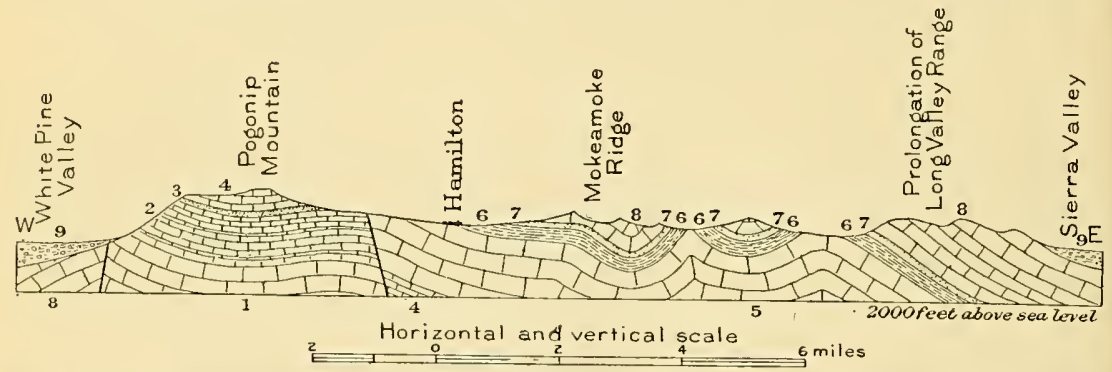

Fig. 2. Sketch section through White Pine Range at Hamilton at the junction of White Pine and Long Valley ranges.

1. Cambrian limestones.

2. Pogonip limestone (Silurian).

3. Eureka quartzite (Silurian).

4. Lone Mountain limestone (Silurian).

5. Nerada limestone (Devonian).
6. White Pine shale (Devonian).

7. Diamond Peak quartzite (Coal Measures).

8. Coal Measures limestone.

9. Valley wash (Pleistocene).

detritus) expose a series of gentle anticlinal and synclinal folds of similar character to the syneline of Mokeamoke Ridge. The structure here is shown in fig. 2 .

\section{FAULTING.}

In the region of Hamilton, where the mountains widen out noticeably, the structure of the rocks west of Mokeamoke Ridge consists in general of a pronounced north-south trending anticline, which affects the central ridge eomprising Treasure Hill and minor eminenees, and, farther west, a general syncline, the western limb of which is Pogonip 
ridge. Within this region also there are a great number of faults, which appear in general to belong to two systems, one having a north-south and the other an east-west strike. The heaviest fault of the region appeared to the writer to be that at the northern end of Pogonip Mountain, where the Coal Measures limestones are brought by a hidden east-west fault directly against the Silurian strata of the momntain. This fault, therefore, must have a vertical displacement of from 7,000 to 10,000 feet. On the northwest corner of Pogonip Mountain another fault was observed, having a considerably less displacement and a northwest strike. Mr. Hague ${ }^{a}$ mentions another heary fault on the western side of the same monntain. Between Pogonip Mountain and the Treasure Hill ridge there is also, aceording to Mr. Hague, ${ }^{b}$ a displacement. In Treasure IIill itself Mr. Hague $^{c}$ deseribed, and the writer subsequently observed, an eastwest fault which crosses from the southeru side of Treasure IIill to Pogonip Mountain. It appeared to the writer also that the steeply bent anticlinal fold which is exposed in an east-west cross section of Treasure Hill has been faulted somewhat along its axis and the eastern part relatively downthrust, the fault being probably a normal one. There are certainly many other faults in the mining district, but all the examinations thus far made have been eursory. On the western side of Mokeamoke Ridge and in Allepaw (Applegarth?) Canyon a number of probable east-west faults were observed.

It will be noted that this faulting is, so far as observed, restricted to the neighborhood of the mining district. To the north and to the south there is little reason for believing that the mountains are much affected by faulting. The White Pine district, then, bears exactly the same relation to the rest of the White Pine Range as the Eureka district does to the Diamond Range. Both are areas of local and special dynamic disturbance, resulting in folding, faulting, and ore deposition, and in both the special effects die out in a surprisingly short distance.

\section{RELATION OF TOPOGRAPHY TO STRUCTURE.}

In the northern part of the White Pine Range, north of the mining region, there is a distinct tendency toward anticlinal valleys and synclinal ridges. The mountains, therefore, though determined primarily by erosion, yet have the location of their ridges and valleys governed by the position of the folds. South of the White Pine mining region the same general peenliarities hold to the southern end of the range.

Within the mining region itself the faults introduce a new feature into the topography. The whole district, as before stated, is traversed 
by a north-south and an east-west system of faults, with minor diagomal ones. Some of these are attended by steep scarps.

In the same district where these scarps occur the folds seem to have directly determined the topography. The Treasure Hill ridge is anticlinal and the valley between it and Pogonip Mountain synclinal. But Mokeamoke Ridge and the ridges to the west are synchinal, with anticlinal valleys, indicating a long-continued erosion period. The folding of the ridges to the west of Mokeanoke Ridge was then distinctly later than that of the ridge itself and later than that of the range in general.

'The faults of the mining district appear to belong also to the same recent epoch as the associated folds. Those of Treasure Hill have apparently been affected very little by erosion, and are marked by scarps which seem to represent very closely the vertical displacement. The same seems to be true of the heavy fault which forms the northern end of Pogonip Mountain, which has already been mentioned.

\section{ORES.}

The structurally complicated region around Hamilton has been the site of rich ore deposition. The ores are distinctly connected with the fault fissures and have formed largely in their vicinity. Mr. Hague ${ }^{*}$ describes the occurrence of the silver deposits of Treasure Hill as (1) in fissures, striking east and west; (2) in deposits between the limestone and shale; (3) in beds or chambers in the limestone and parallel to the stratification of the rock; and (4) in the regular seams or joints across the rock bedding, most frequently with a northsouth trend. The minerals found in the mining district comprise quartzite, calcite, gypsum, flnorite, barite, black oxide of manganese, rhodochrosite, cerargyrite, galena, cerussite, and azurite. The district once had a population of many thousand, but at present there is very little activity.

\section{QUINN CANYON AND GRANT RANGES.}

The Grant Range is really the southern extension of the White Pine Range, there being no decided break between the two. It has a length from north to south of about 30 miles. The Quimn Canyon Range is closely connected with the Grant Range, being separated only by a narrow rock-cut valley, whose bottom is for the most part comparatively free from detritus. It is, however, offset from the Grant Range to the west. The Quinn Canyon Range is broad and short, having a north-south extent of about 25 miles, and an east-west extent of nearly 20 miles.

TOPOGRAPHY.

The Grant Range consists of a single main ridge, rather flat and broad on top, and cut up deeply by the smaller mountain valleys, 
which rmu out into the wide detritus-filled main valleys. These smaller valleys and their auxiliary gulches are generally bounded by steep walls. In general, the main mountain fronts, on the east and west, are also steep. The south end of the range, which lies just east of Garden Valley, decreases gradually in height, and so passes into a series of low buttes which run ont into the valley.

'The Quinn Canyon Range is bounded by steep cliffs on the east, west, and north sides of its northern half, and the small ralleys and ravines which have been worn in this half are guarded by the same precipitous walls as in the Grant Range. This part of the range is cut out of limestone; hence its rugged and irregular topography. The southern part of the range is a mass of volcanic rocks, which, however, have been extensively eroded. The type of topography is naturally quite different from that in the limestone region, the distribution of the valleys being regular and the rocks being cut up into steep but not precipitous mountains. The southern end of the range also appears to have a more gradual descent into the plain that has the northern.

\section{SEDIMENTARY ROCKS.}

CAMBRIAN.

In the foothills at the north end of the Quinn Canyon Range and to the north of the abrupt scarp which limits the norther'n end of the mountain proper an exposure of rusty-brown shaly limestone was found in a canyon, from which fossils were collected. They were determined by Mr. Walcott as Cambrian.

These were the only Cambrian rocks found in the two ranges. Immediately to the south, in the high mountains of the Quinn Canyon Range, the rocks are Silurian and probably also Devonian, and indeed an onterop of undoubtedly Silurian quartzite (Eureka formation) was found only a short distance east of the Cambrian locality. The attitude of the beds in both outcrops makes it clear that between the two there is a heary fault, and from the lack of faulting in the Quinn Canyon Range proper it is clear that the fault does not run in a north-south direction, but must run in a general east-west direction, not far from the base of the heary scarp which delimits the mountain at its north end.

\section{SILURIAN.}

On the steep west face of the northern end of the Quinm Canyon Range the mountains near the base consist of massive, often shaly, dark-blue to gray-blue limestone, much broken and veined as a consequence of granitic intrusions. On account of the alteration the organic remains obtained from this limestone are not identifiable. Six hundred or $\$ 00$ feet above the base of the limestone, as exposed, comes about 200 feet of hard white vitreous quartzite, which one at once recognizes as probably the Eureka formation. Above this quartzite comes upward of 4,000 feet of gray-blue extremely massive limestone, extending to the top of the mountain and weathering into 
smooth, perpendicular, pinuacled cliffs. This same limestone was found all along the north end of the mountain searp, and also forms the precipitous eliffs on the east side of the mountain front, opposite the Grant Range.

In some low foothills on the northern slope of this range, facing Railroad Valley, the following Ordovician fossils (determined by Professor Ulrich) were found by Mr. F. B. Weeks ${ }^{a}$ in 1900:

Girvanella sp. undet.

Orthis n. sp. (cf. O. holstoni Safford).

Dalmanella perveta.

Orthis tricenaria?

Cf. Strophomena nemea H. \& W.

Zygospira 11. sp. A large species, $\frac{1}{2}$ inch or more wide.

Three undetermined brachiopods. possibly referrable to Platystrophia.

Orthorlesma sp. mulet.

Lophospira.

Cf. Plenrotomaria lonensis Walcott.

Orthoceras.

Leperditia (near L. fabulites Conrad).

Leperditella sp.

Primitia (near P. celata Ulrich).

Bathyurus (1).

Bathyurus (2).

Bathynrus (3).

Within the main range, on the slopes of Big Creek, in the northwestern part of the range, the following Ordovician fossils were collected by Mr. Weeks, determined by Professor Ulrich:

Receptaculites mamnilaris Newberry.

Receptaculites ellipticns Walcott.

Plates of a large Carabocrinns similar to one occurring in shales of Black

River age of Minnesota.

Plates of Carabocrinus ? with pnstnlose surface.

Monotrypa sp. midet.

Batostoma sp. mindet.

Orthis n. sp. (near O. holstoni Safford).

Orthis pogonipensis H. \& W. (cf. O. perveta).

Orthis tricenaria Comrad (small form).

Orthis lonensis? Walcott.

Machurea sp. undet. (near M. bigsbyi).

Gyronema sp. nov. (near G. semicarinatum Salt. sp.).

Gen. et sp. nov. (related to Oxydiscus and Conradella).

Orthoceras (small species).

Endoceras sp. undet. (with "Colpoceras " type of siphnncle).

Leperditia n. sp. (semipunctate).

Leperditia n. sp. (elongate bivia).

Leperditella sp. (near germana Ulrich).

Leperditella sp. with ventral swelling in left valve.

Schmidtella n. sp. (near S. crassimarginata).

Aparchites sp. undet.

Tetradella? sp. nov.

Cranidia and pygidia of six (?5) species of Trilobites. 
On the east side also the Eureka quartzite again appears and can be continuously traced for long distances, thus becoming an important aid in the study of the stratigraphy. In the valley which separates the Quinn Canyon Range from the Grant Range the Eureka quartzite outerops on both sides, on the two limbs of an anticlinal fold from which the valley has been eroded. In the hottom of the valley, beneath the quartzite, is found massive limestone, breceiated, hardened, and altered. In the npper part of that portion of the valley draining north (which is separated by a decided divide from that portion which drains to the sonth into Garden Valley) the ascent takes one above the horizon of the Eureka quartzite into that of the overlying limestones. Along the course of this northern part of the valley no good fossils could be found in any loeality, but fragments picked up at various points in the canyon have been identified by Professor Ulrich as Silurian.

Batostoma? sp. mndet.

Bathyurus? sp. undet.

Leperditella? sp. mdet. Two species.

Orthis sp. (near O. holstoni Safford).

Orthis sp. (near O. tricenaria).

Receptaculites ellipticns Walcott.

At the divide above mentioned the stratified rocks are hidden by later voleanies. A short distance south of the pass, however, the Eureka quartzite is again encountered, and above it the same heavy limestone as appeared in the Quinn Canyon Range. These rocks extend quite through to the eastern face of the Grant Range. On the lower part of Cherry Creek, after passing the volcanic area, dense blue limestone is eneountered, and farther down the Eureka quartzite. From the limestone berls, a few hundred feet below the quartzite, the following Ordovician fossils were obtained and determined by Professor Ulrich.

Eccyliopterus sp. undet.

Encrinurus sp. undet.

Isotelus?.

Lingula sp. undet.

The Eureka quartzite, dipping to the east, forms the eastern front of the Grant Range for some miles north of Cherry Creek, and then, on account of the irregular erosion of the monntain front, passes into the foothills, where it ean be traeed for a number of miles farther north.

DEVONIAN.

No Devonian fossils were obtained from either the Quinn Canyon or Grant ranges. As already noted, however, the thickness of the limestone section which is exposed above the Eureka quartzite is upward of 4,000 feet in both ranges. In the Eureka seetion ${ }^{a}$ the thickness of the Silurian Lone Mountain limestone above the Eureka quartzite is 
given at 1,800 feet. There is an unconformity at Eureka between the Eureka quartzite and the overlying limestone. Nevertheless, it is very likely that the upper portion of the massive limestone observed in the Quinn Canyon and Grant ranges includes part of the Devonian limestone of the Nevada formation.

\section{CARBONIFEROUS.}

On the eastern slope of the Grant Range, north of Warm Spring, in White River Valley, the following Carboniferous fossils were collected by Mr. F. B. Weeks ${ }^{a}$ and determined by Dr. Girty:

Chonetes sp.

Chonetes illinoisensis.

Derbya kaskaskiensis.

Productella? near concentrica.

Spinifer centronatus.

Camarotoechia sp.

Enmetria verneniliana.

Naticopsis sp.

Ostracoda.

PLIOCENE.

In the northern part of the valley separating the two ranges there are found, up to a height of 6,200 feet above the sea, horizontally bedded arkoses and conglomerates, made up of the fragments of the limestone cliffs above and nevertheless hardened into solid rocks. This may be a shore formation, and may belong to the Pliocene lake whose sediments are shown in the Pancake Range at Twin Springs and at IIot Creek. The Pleistocene subaerial accumulations hide the Tertiary strata throughout the greater part of the valleys. A hint of the former existence of a Pliocene lake on the west side of Quinn Canyon Range, however, was found in the peculiar development of the gulches which furrowed the volcanic rocks. These gulches are deepest at the top, and grow progressively shallower lower down, mitil near the bottom they die out entirely. This may signify that the development of the gulches began above the surface of the Pliocene lake and as the lake became lower the gulches were forced to extend themselves, but naturally accomplished only a small amount of cutting in those new portions as compared with the long-established upper parts.

\section{IGNEOUS ROCKS.}

RHYOLITE AND GRANITE.

On the west side of Quinn Canyon Range, directly east of Twin Springs, are found great masses of siliceous igueous rocks which widen in extent farther south and cover up the whole of the range. ${ }^{b}$ At the northern end of the mountain valley which separates the most easterly part of the range from the westerly part, along which the Quinn Canyon 
road ruus, the roleanic rock has been stripped down to the underlying limestone, which is fomd to be traversed by great dikes of acid rock, varying from coarse to fine in textme. The overlying rhyolite and the dike rocks were examined microscopically. Of two specimens of the dikes one was a coarse biotite-hornblende-granite and the other a very fine biotite-granite-porphyry, the same mineralogically as the coarse variety, but both mineralogically and structurally far more closely comnected with the rhyolite. ${ }^{a}$ It is probable, therefore, that the dikes and the massive eruptions constitute different parts of the same igneous mass.

BASALTIC VOLCANICS.

In the small valley between the two ranges, thin-bedded basaltic voleanies oecur just sonth of the pass and stretch over a considerable area. These rocks are fine grained or glassy and show very beatiful flow structure, in strong contrast to the massive, rugged rhyolite in the hills abore them. Specimens examined microscopically show the rock to be a basalt carrying angite and hornblende. The basaltic rocks extend for some distance along Cherry Valley.

\section{QUARTZ-LATITES.}

On the east side of the Grant Range, near the point where it joins the White Pine Range, the ontlying foothills which bound the sonthern or sonthwestern end of Sierra Valley are evidently composed of dark-colored volcanic rock. This is not far from similar volcanic areas which form the northerly continuation of the Golden Gate Range, and is very likely of the same nature. From one of the volcanic hills of the Golden Gate Range near this point a specimen proved to be quartz-latite, containing angite, biotite, and hornblende.

RELATIVE AGE OF LAVAS.

In these two ranges the rhyolites are distinctiy oldest, as shown not only by the fact that the more basic lavas overlie them, but also by the greater erosion of the rhyolites as compared with the others. The latite appears to be of intermediate age. It is probable that the rhyolites and the basalts are to be correlated with the corresponding lavas of the Paneake Range, as exhibited at T'win Springs.

\section{STRUCTURE.}

FOLDING.

At the west base of the Quinn Canyon Range the distribution of the Eureka quartzite shows that there exists here an anticline with a north-sonth or northeasterly-southwesterly axis. The north end of the range exposes a broad, very shallow syncline, which succeeds the anticline to the east. In the center of this syncline the beds are horizontal for a considerable distance, and the maximum dip on 


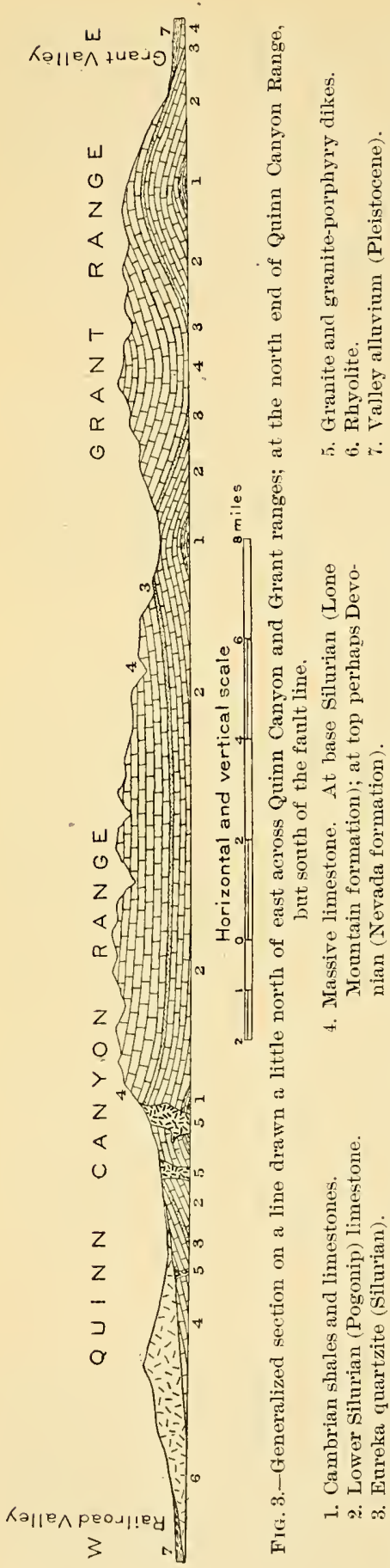

the two sides is about $35^{\circ}$. The syncline is snceeeded farther east by an anticline, along which the valley separating the two mountain ranges has been eroded. The Enreka quartzite, which appears on both sides of this anticline, allows its being traced easily for long distances. The fold has a general north-northwesterly trend and is visible in the mountains of the Grant Range about 8 or 10 miles to the northeast of the north end of the Quinn Canyon Range. At this point it is much sharper than farther south.

The eastern $\operatorname{limb}$ of the anticline, which is steeper than the western limb, is at the same time the western limb of a syncline which is displayed in the Grant Range. There are some slight minor folds, but the general cross section appears to show a perfect syncline at a point just east of the north end of the Quimn Canyon Range. Farther south, in the vicinity of Cherry Creek, the jutting out of the mountains a little farther east, as a consequence of the irregular erosion, permits the study of a third anticline, which succeeds the syneline, and is a heavy and persistent fold. Looking north from the vicinity of Cherry Creck, one sees this anticlinal fold passing from the side of the mountains into the foothils, so that the strata which at first dip easterly on the monntain face change to a westerly dip, which denotes the eastern limb of the Grant Range syncline. These folds have a more northeasterly strike than those farther west, so that the easternmost anticline just described probably strikes across the valley to the low hills which divide the Golden Gate Range from the Grant Range about 20 miles north of Cherry 
Creek, and is again exhibited in the strata of these hills. At this point the anticline is joined on the east by a connected series of open synclines and anticlines, which form the low monntains of the Golden Gate Range and extend across to the northern end of the Hiko Range.

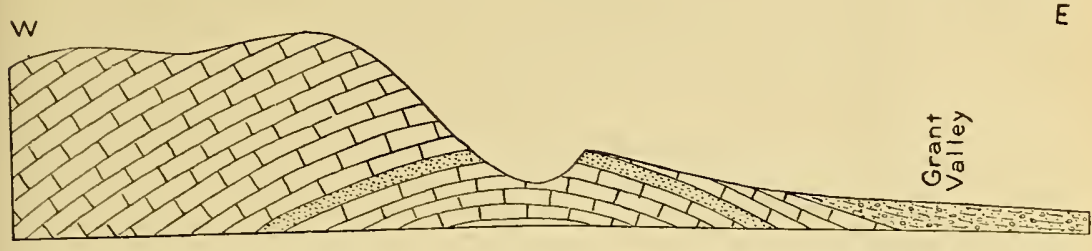

Fig. 4.- Sketch section of east front of Grant Range. Taken 5 miles north of fig. 3 and showing altered position of anticlinal fold with reference to the mountain front.

The strikes of these folds become more and more easterly until in the Hiko Range they swing round and become southwesterly, and then, farther sonth, pass into the usual north-sonth trend again, having described semicircles. (Sec figs. 3 and 4. )

\section{FAULTING.}

As already mentioned, there is apparently a heavy fault at the norther'n end of the Quinn Canyon Range, which has brought up the Cambrian rocks on the north side against the Silurian on the south. This was the only fault determined in the two ranges. (See fig. 5.)

s'
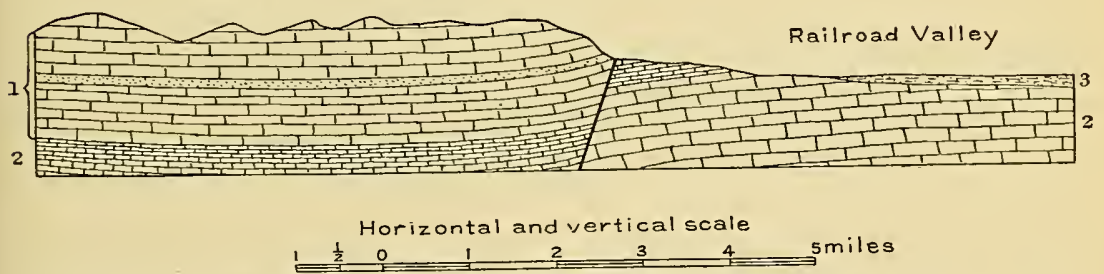

FIG. 5.-Generalized sketch section of north end of Quinn Canyon Mountains.
1. Silurian limestones and quartzites (probably
2. Cambrian limestones and shales.
Deronian on top).
3. Chiefly Pleistocene ralley wash.

Some slight crumpling of the strata was observed on the eastern side of the Grant Range, near Cherry Creek, but this was probably dne to the intrusion of the near-by volcanic rocks. In general, the folds of the stratified rocks are even and unbroken.

\section{RELATION OF STRUCTURE TO TOPOGRAPHY.}

As described, the Quinn Canyon Range is essentially a simple syncline, as is also the Grant Range. On the west side of the Quimn Canyon Range, the east side of the Grant Range, and also between 
the two ranges, are anticlines which are marked by deep depressions. In general, therefore, the form of the mountains is one that implies a long period of erosion subsequent to the folding. Although the faces of both these ranges, on the east and on the west, are somewhat abrupt, the apparent continuation of the beds past these steep faces without break indicates that the faces are not caused by fanlting, but are due to erosion. The north end of the Quinn Canyon Range is probably along a fault, but in this case the Cambrian rocks, which have been relatively upthrust by the faulting, are found in low footliils running into the valley, while the downthrust Siluirian rocks form abrupt cliffs facing the Cambrian. It seems, therefore, that if the cliff was primarily determined by faulting it is not directly due to upthrust, but to powerful erosion.

\section{WORTHINGTON MOUNTAINS.}

The Worthington Monntains are a very small gronp lying northwest of the Pahranagat Range, with which they are connected by a series of hills. They also are connected with and probably form the northern extension ef the Timpahute Range, and on the north the rocks are probably continuous with those of the Grant Range, from which they are separated by a few miles of desert valley. On the west side of the Worthington Mountains there is a series of low hills which form a certain connection between them and the Quinn Canyon Range.

Like most of the high monntains of the region, as, for example, the Quinn Canyon Range and the Grant Range farther north, the Worthington Mountains have steep sides, averaging perhaps $30^{\circ}$ in inclination to the horizontal, to the east, west, and north.

\section{SEDIMENTARY ROCKS.}

The northern end of the range was viewed by the writer from a point several miles farther north. From here the rocks are apparently massive limestones, resembling the Devonian and Silurian strata of the Grant Range just to the north, and having a similar strike. These same strata can be traced southward along the flanks of the momntains. At the northern end, according to Mr. Gilbert, ${ }^{t}$ they consist principally of limestone, with some sandstone. The limestone carried abundant fossils, which probably belong to the Silurian.

\section{IGNEOUS ROCKS.}

According to Mr. Gilbert, the northern end of the mountain is flanked on the east by beds of rhyolite, associated with which are the Freiberg silver mines. 
STRUCTURE.

At the northern end of the range the strata dip westerly about $30^{\circ}$, parallel with the general slope of the range. Farther south the dip grows continually less, until at the southern end it is horizontal. It was at this point observed by Mrr. Gilbert, who interpreted the horizontal structure of this bold mountain as determined by faults on both sides, the mountain being an upthrust block between the two. Considering the change in attitude between the south and north ends, however, it may also be that the mountain represents part of a fold whose strike diverges slightly from the trend of the ridge.

\section{PANCAKE RANGE.}

TOPOGRAPHY.

The northern end of the Pancake Range lies just east of Eureka, where it terminates in White Pine Valley. North of this termination and across the valley is Coal Burner or Bald Monntain, a prominent eminence which appears to be in geologic continuity with the Pancake Range, but which is more closely connected topographically with the. southern end of the Humboldt Range. To the south the Pancake Range extends in a straggling fashion as far as Twin Springs, a distance of about 100 miles, with a general trend a little west of sonth. At Twin Springs a narrow pass separates the Pancake Range from the Reveille Range, farther south. There is, however, no real break in the topographic continuity here, and the distinction is therefore somewhat arbitrary.

The Pancake Range is low and without striking relief, as its name indicates. The northern end of the range consists in part of limestone ridges with general northwest trends, diagonal to the trend of the range. Flanking these limestone ridges are somewhat dissected but nevertheless level-topped voleanic mesas. South of the road between Eureka and Hamilton is a considerable area of shaly Devonian rocks, which are eroded into low smooth hills. About 8 or 10 miles farther south, with the covering up of the stratified rocks by later eruptives, a corresponding change in the topography takes place. The single main ridge divides into a number of irregular parallel ridges and the low smooth hills change to higher ones which, though sometimes rounded, are often sharp or conical. The tops of these hills often join to form a general mesa. This type of topography extends to the extreme southern end of the range.

\section{SEDIMENTARY ROCKS.}

CARBONIFEROUS.

In the northern end of the range limestones and conglomerates associated with thin seams of impure coal have been reported. ${ }^{a}$ These 
limestones contain numerous species of Carboniferous fossils. The writer also collected Upper Carboniferous fossils from the vicinity of the road which crosses the Pancake Monntains between Eureka and IIamilton. One locality afforded the following species, which were determined by Dr. Girty:

\footnotetext{
Fusulina cylindrica.

Fistulipora? sp.

Derbya sp.

Chonetes verneuilianus.

Rhipidomella pecosi.

Productus sp.

Prortuctus nebraskensis?

Marginifera muricata :

Seminula subtilita?
}

Another locality, about 2 miles sontheast of the first, yielded Chcetetes milleporaceus, Spirifer rockymontanus, Phillipsia sp.

These fossils were in shaly gray limestone, which was overlain by more massive limestone, interstratified with occasional belts of conglomerate containing pebbles of quartzite and chert.

DETONIAN.

Sonth of the road mentioned come in the sandy and limy shales of the Devonian White Pine formation. ${ }^{a}$ 'This shale is associated with beds of brown sandstone which contains plant remains.

TERTIARY.

On the west side of IIastings Pass, in the Humboldt Range, near the northern end of White Pine. Valley, are sediments to which was given the name of the $\mathrm{Humboldt}$ Pliocene, and which were described and mapped by the Fortieth Parallel Survey. These beds were examined by the writer and were found to consist largely of limestone fragments derived from adjacent Silurian rocks. They abut against the mass of the Humboldt Range in such a manner as to show that this range formed their shore line and that they were deposits formed when the valley had practically its present shape.

In other parts of the valley the Pliocene deposits are generally covered with Pleistocene accumulations, and are therefore not discernible. Along the Pancake Range, however, on the east side of the extreme southern end of Little Smoky Valley, stratified deposits similar to those on the flanks of the Humbollt Range were found, forming a fringe around the mountains.

At Twin Springs the canyon which has been worn transversely across the mountains exposes a section of Tertiary stratified rocks, lying between the Tertiary voleanies. The section shows rhyolite at the base. Above this comes several hundred feet of horizontally bedded 
water-laid semieompacted sandstones, apparently derived from the rhyolite. At the top of this stratified series the white sands change to stratified tuffs and gravels, brown in color and evidently derived from basic lava such as immediately overlies them. This lava is a solid dark-colored basalt, which forms the uppermost member of the series.

\section{PLEISTOCENE LAKE.DEPOSITION.}

At several points the marks of a comparatively recent body of water, oceupying a large part of Big Smoky and White Pine valleys, were observed. On the east side of the Diamond Range, about 10 miles north of Pinto Creek, distinct terraces were observed in the detritus at the base of the mountains. Tlese terraces are several in number and are 50 or 60 feet above the valley floor. Also about 15 miles south of Fish Creek a regular bench composed of lava débris was noted on both sides of the valley, about 15 feet above the smooth mud deposits of the valley bottom. Farther north, at a point on the Pancake Range just south of the road between Eureka and Hamilton, at the mouth of a gap in the hills, a definite beach bar was noticed, such as forms along gently sloping shores at the mouths of inlets.

There was therefore probably a Pleistocene body of water which spread over the greater part of Little Smoky and White Pine valleys. The shore marks above mentioned indicate that this lake was shallow. The final remains of the Pleistocene lake may be considered as still existing in the numerous marshy ponds which are scattered through the White Pine Valley north of the Pancake Range.

\section{GULCH DUMPS OR ALLUVIAL FANS.}

Along the line of junction of the mountains with the valleys, and occasionally forming the low foothills, are sometimes observed accumulations of detritus which rise above the level valley floor, and which have such relation to the gulches of the mountains above that it is plain their materials have been derived from their erosion; and in some cases it seems that the amount of material in these dumps is a very large portion of that which has been removed in the excavation of the gulches. Where this material is exposed at the surface, it is found to be angular and bearing other marks of having been brought down by torrents.

These accumulations are certainly, in part at least, Pleistocene, and are being adrled to at present. However, they antedate largely the Pleistocene water body above described. They are therefore PliocenePleistocene, and are largely contemporaneous with the water-laid deposits which occur at lower altitudes.

IGNEEOS ROCKS.

At the northern end of the Pancake Range a body of rhyolite forms the western half of the mountains and extends as far south as the 
road between Eureka and Ilamilton. A short distance south of this road andesite comes in in considerable patehes. ${ }^{a}$ This andesite was observed by the writer at intervals for a distance of 10 or 15 miles sonth of here. It is here generally mixed up with small areas of rhyolite. Still farther south rhyolite seems to form the greater part of the range $(P I . V, B)$. In the neighborhood of Twin Springs, as mentioned above, the rhyolite oceurs at the base of the section and basalt at the top.

\section{STRUCTURE.}

FOLDING.

The area of White Pine Devonian rocks, above described, forms a shallow syncline which apparently gives place to a gentle anticline farther north, and there exposes the Carboniferous limestones. It is possible, however, that it is a fault which brings np these limestowes. The syncline has a general northwest strike and is plainly continuous with the faulted syncline of the Enreka district, just across the valley, which has Newark Mountain on its eastern limb and the Alhambra Hills on its western. This synchine may be traced across the Pancake Mountains and across the intervening low hills to the White Pine Range, its strike being at an angle to the general trend of the major ridges, although the minor ridges conform to it.

\section{FAULTING.}

The Upper Carboniferous limestones on the road across the range, between Eureka and Hamilton, have perhaps been brought to their

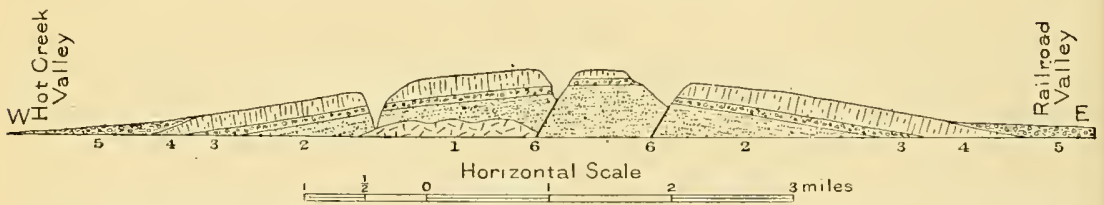

Fir. 6.- Cienemalized sketch cross section of Pancake Range at north side of pass at Twin Springs.

1. Rhyolite, 200 feet.

2. Rhyolite sandstone, 600 feet.

3. Basaltic tuffs and graveis, lou feet.
4. Olivine-basalt, 200 feet.

5. Valley wasil (Pleistocene).

6. Faults.

present position by an east-west fanlt, transverse to tho trend of the range, for their relation to the Devonian rocks just south of here can not be readily explained by the folding.

The accompanying section (fig. 6) shows the structure of the Paneake Mountains at Twin Springs. There has been practically no folding here, except where the beds have been locally crumpled by overriding sheets of lava. A series of faults was observed, some of which have a throw of several hundred feet. The fault lines are accompanied by gullies, but not by fault searps. 
COAL.

In the northern end of the Pancake Range the Carboniferous rocks carry thin seams of impure coal, which have been in vain explored for marketable material. ${ }^{a}$

\section{DIAMOND RANGE.}

The Diamond Range maly be somewhat arbitrarily defined as beginning at Railroad Canyon on the north, and extending southward through the Eureka Mountains to Fish Creek. South of Fish Creek comparatively low mountains occur. No decided break separates these from the Eureka Mountains, but they are more closely associated with the Hot Creek Range, and will be described in the latter connection.

\section{TOPOGRAPHY}

The main part of the Diamond Range, from its northem end to the vicinity of Enreka, consists of a single narrow, somewhat regular ridge, whose divide is in the center. This is sharply cut up on both sides, so as to present a succession of well-defined peaks, with deep drainage chammels.

In the neighborhood of Eureka this simple topographic structure changes to a more complicated one, which is the expression of a geologic structure more complicated than that to the north. 'The monntains in the vicinity of Eureka are considerably folded, and are traversed by numerous faults, which run in several directions. The result of the erosion of this structurally complicated region is that there have arisen many separate mountain ridges, and the total width of the range has increased.

South of the Eureka Mountains the range is eomposed of a single narrow ridge of stratified rocks, which seem to resume the comparatively simple structure of the northern portion. Just south of here the sedimentaries are buried under thick sheets of lava.

SEDIMENTARY ROCKS.

At the nothern end of the Diamond Range, at Ratiload Canyon, the rocks have been described by $\mathrm{Mr}$. Hague ${ }^{b}$ as light creau-colored limestones dipping to the north under sheets of basalt. These limestones are mapped by the Fortieth Parallel geologists ${ }^{c}$ as the Lower Coal Measures.

The writer traveled along the easterly face of the Diamond Range, from a point just west of Hastings Pass, in the Humboldt Range, to the southern termination. At the northern end of the traverse a sec-

a Mon. U. S. Geol. Survey Tol. XX, p. 95.

$b$ U. S. Geol. Expl. Fortieth Par., Vol. II, p. 549.

cIdem, Atlas, map 4, west half.

Bull. $208-0: 3-6$ 
tion of strata is visible, which, in defanlt of opportunity for examination, was provisionally supposed to have the Devonian White Pine shale of Eureka at the base, with the Carboniferous Diamond Peak. quartzite above.

The thiekness of the exposures of these two formations was roughly estimated at from 2,000 to 2,500 feet. Above this section were observed comparatively massive limestones which were taken to be the Lower Coal Measures linestones, and of these an estimated thickness of 4,000 feet was observed. Above these again are heavy brown-weathering massive rocks forming the precipitous crest of the range for a long distance. 'These were thought to belong to the Weber formation. About 1,500 feet of this was visible, the top not being seen. Mr. Hague ${ }^{a}$ notes that at Chokup Pass, which is within the above section, limestones occur in which no fossils were found. "In the limestone occurs a belt of eoanse, although compact, brownishyellow sandstone, not unlike the sandstone body at White Pine, which lies at the base of the Coal Measmres limestome. It measures nearly 300 feet in thickness." This is, perhaps, the Dianond Peak quartzite, as it was afterwards called by the geologists who studied the Eureka district.

South of Chokup Pass the same formations occur. In the eastern foothills the Diamond Peak quartzite outerops, brown, iron stained, friable, and calcareous, resembling exactly the same formation as exposed in the Egan Range, in the canyon west of Ely. The quartzite becomes at times a conglomerate, containing pebbles of chert and limestone. It is possible that this conglomerate indicates an erosion interval between the Carboniferous and the underlying Devonian.

A few miles farther south, the strike of the Diamond Peak quartzite having carried it temporarily under the valley detritus, the eastern foothills are composed of the overlying dark-blue limestone with chert nodules. This limestone carries the following abundant fauma, determined as Upper Carboniferous by Dr. Girty:

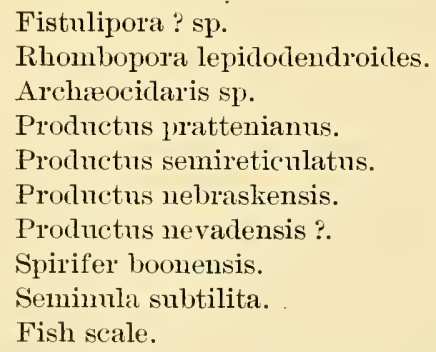

Still farther south a change in the structure brings in the Diamond Peak +quatzite again, together with the underlying Devonian rocks, and the strata rise rapidly to the top of the range.

In Chihuahna Canyon, which lies to the east of Diamond Peak, 
slightly fetid limestone was found, and at a point about 1,000 feet above the bottom of the series exposed were Devonian fossils, as determined by Dr. Girty.

Amphipora? sp.

Spirifer engelmanni.

Spirifer, indeterminable.

Spirifer maia (small variety) ?

Atrypa missouriensis.

This is part of the Nevada limestone, for the Deronian White Pine shales come in about 500 feet above.

South of here the geology has been thoronghly worked ont during the survey of the Eureka mining distriet, which survey embraces the region from Diamond Peak on the north to White Cloud Peak on the south.

Within this area is found exposed the best Paleozoic section yet studied west of the Roeky Mountains, comprising strata from the Prospect Mountain Cambrian quartzite, through the Cambrian, Silurian, Deronian, and Carboniferous. ${ }^{a}$

South of the Eureka mining district proper, the single ridge into which the mountains contract is shown in the geologic map of the Eureka district ${ }^{b}$ to be composed of the Silurian Pogonip limestone. This limestone extends farther south till covered up by volcanic flows.

IGNEOUS ROCKS.

At the northern termination of the Diamond Range the stratified rocks are overlain by flows of basalt. ${ }^{c}$ Between this point and the region around Eureka no igneous rocks were observed. The Eureka district, however, has been the seat of volcanie activity. Among the volcanic rocks, hornblende-andesite, dacite, rhyolite, pyroxene-andosite, and basalt have been described by Mr. Iddings. ${ }^{d}$ Granite-porphyry is also found as a dike rock.

The voleanic rock which occurs at the sonthern termination of the range has been determined by the writer, a few miles farther south, to be rhyolite.

\section{STRUCTURE.}

North of the Eureka district the stratified rocks of the Diamond Range are bent into a series of gentle folds which in general strike nearly with the trend of the range. In the region between Chokup Pass and Railroad Pass these folds seem to eonsist of an anticline on the east side, with its eastern limb almost buried by the detritus of the valley, followed by a shallow broad syncline to the west, and this

a Arnold Hague, Geology of the Eureka district, Nevada: Mon. U. S. Geol. Survey Vol. XX; C. D. Walcott, Paleontology of the Eureka district: Mon. U. S. Geol. Survey Vol. VIII.

b Mon. U. S. Geol. Survey Vol. XX, Atlas sheet 4.

c Arnold Hague, U. S. Geol. Expl. Fortieth Par., Vol. II, p. ǒ 49.

dMon. U. S. Geol. Survey Vol. XX, p. 233 et seq. 
in turn by an important anticline which seems to form the western edge of the mountains.

At Chokup Pass Mr. Hague " notes the general anticlinal structure of the mountains, the summit of the anticline occupying the crest of the pass. This is the same antieline as has just been noted as forming the westem face of the mountains to the north of the pass, the slight divergence of the strike of the fold from the trend of the mountain bringing the fold to this place. Farther south the continued divergence brings the axis of this anticline at one point down to the easternmost foothills. As a consequence of this, the syncline and anticline which lie to the east are covered by valley detritus. Farther south still, as one approaches the vicinity of Diamond Peak, the trend of the folds ehanges slightly and again brings the erest of the easternmost anticline to the summit of the range.

South of Diamond Peak the country in the neighborhood of Eureka is a region of special dynamic distmbance, and is folded and faulted to a remarkable degree. Except in this district, however, no faults have been observed in the range.

\section{RELATION OF STRUCTURE TO TOPOGRAPHY.}

North of the Eureka district the structure has been so far influential that the trend of the range corresponds nearly to the generat strike.

In the Eureka district the complicated topography is dependent upon the increased complications in the geology, but the forms appes. to be directly due to differential erosion. Most of the faults here are oblique to the general trend of the range. Along these faults valleys or canyons are sometimes found, and sometimes moderate scarps; but that these latter are due to differential erosion is shown by the fact that it is sometimes the downthrown side of the fault that appears as a searp and sometimes the upthrown, depending upon the nature of the beds.

\section{ORES.}

The whole district around Eureka has been the site of abundant ore deposition, a phenomenon plainly eonnected with the dynamic disturbances which have brought about the complicated folding and faulting (and indirectly the topography) and with the volcanic outbursts. The ore deposits of Eureka have already been thoroughly studied." Outside of this region the range is not remarkably ore bearing.

\section{HOT CREEK RANGE.}

The Hot Creek Range is separated at its south end by a narrow pass from the Kawich Range, which otherwise is continuous with it.

$a$ U. S. Geol. Expl. Fortieth Par., Vol. II, p. 549

bJ. D. Curtis, Silrer-lead deposits of Eureka: Mon. U. S. Geol Survey Vol. VIJ; Arnold Hague, Geology of the Eureka district: Mon U. S Geol survey Vol. XX. 
From here it runs north 70 miles and disappears in a valley a few miles south of the latitude of Eureka. In the same line, farther north, occurs the Piñon Range. The northern continuation of the Hot Creek Valley divides the mountains into an east and a west half. The western half is the continuation of the Hot Creek Range proper, while the easteru one runs north and joins the Eureka Mountains.

\section{SEDIMENTARY ROCKS.}

SILURIAN.

At the eastern end of the canyon, at Iot Creek, the following section was observed, beginning with the bottom:

Section at Hot Creek.

1. Thin-bedded, dark-blne frosty-lustered limestone, calcite-veined, with imperfect fossil remains ..... . . . . . 400

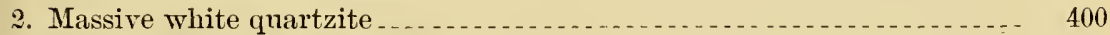

3. Thin-bedded dark-blne limestone .... 200

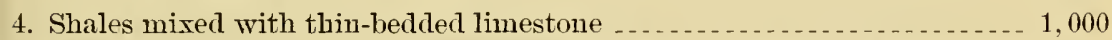

5. Massive light-gray coarsely crystalline limestone, constituting the top of

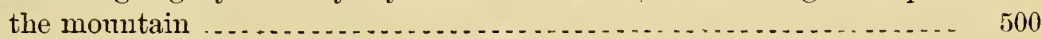

Three miles west of this locality, at the ranch near Hot Springs, there comes in, below bed No. 1, more massive siliceous light-gray, coarsely crystalline or aphanitic limestone about 600 feet in thickness. This makes about 1,000 feet of limestone in all below the quartzite.

From the first-named locality, at a point about 200 feet below the quartzite, Ordovician fossils were obtained. 'The following were determined by Professor Ulrich:

Amphion (sp. near A. salteri Billings).

Illænus (sp. near I. americanus, consimilis, and crassicanda).

Bathyurus sp. undet.

Leperditia bivia White.

Leperditia n. sp.

Aparchites sp. undet.

Primitia (sp. near P. celata Ulr.).

Primitia (: Eurychilina) n. sp.

Eurychilina (near E. subæquata) Ulr.

Schmidtella n. sp.

Thlipsura: n. sp.

Modiolopsis occidens, Walcott.

Maclurea.

Tetranota (n. sp. near T. obsoleta Ulr.).

Lophospira (cfr. medialis Ulr.).

Plemrotomaria? lonensis Walcott.

Triptoceras sp. nndet.

Orthis n. sp. (near O. holstoni Safford).

Dalnianella pogonipensis. $\mathrm{H}$. and $\mathrm{W}$.

Batostoma, sp. undet. 
It is, then, plain that the quartzite is the Eureka quartzite of the Eureka section, while the limestone below corresponds to the Pogonip formation and that above to the Lone Mountain. We have here a section of about 3,100 feet of Silurian rocks, comprising 1,000 feet of the Pogonip, 400 feet of the Eureka, and 1,700 feet of the Lone Mountain.

A few miles south of the above locality, in the next canyon to the south of IIot Creek, there were collected from the limestones above the quartzite the following Upper Silurian fossils (Niagara?), as determined by Professor Ulrich:

Halysites catenulatus, large variety.

Halysites catenulatus, small variety.

Favosites (ramose species).

Syringopora sp. undet.

Amplexus sp. undet.

Cyathophyllum sp. undet.

Zaphrentis? sp. undet.

Rhynchonella sp. undet.

At 'Tybo, about 15 miles south of IIot Creek, and also on the east side of the range, the rocks appear to be mainly massive dark-blue limestones with a general westerly dip. This locality was not visited, but a single fossil obtained from these limestones was regarded by Dr. Girty as probably Ordovician, Maclurea annulata?

From Tybo to the south end of the range, just west of Twin Springs, in the Pancake Range, the east half of the mountains is entirely composed of similar limestones. At the extreme south end the limestones are overlapped by the rhyolites of the Kawich Range, which have altered the sedimentary rocks. No fossils were found at this point, but a specimen of the limestone was seen under the microscope to be made up of tiny indeterminable organic remains.

\section{TERTIARY.}

On the eastern side of the range, extending from Hot Creek a number of miles in both directions, are gray hills composed of partly consolidated coarse gravel and grit. This material often overlies rhyolite, from which it is partly derived, and it rests against the steep eroded base of the limestone mountains. The material is evidently waterlaid. The same formation stretches southward and is visible near Tybo as a strip of yellow dissected hills. At the pass between the Hot Creek Range and the Kawich Range are large amounts of horizontally stratified white waterlaid deposits composed of rhyolitic fragments. ${ }^{a}$

This formation is evidently the same as described in the neighborhood of Twin Springs, in the Pancake Range, a few miles to the east.

a This formation is chiefly included nnder the color for volcanic rocks on the map. 'The narrow strip near Tybo is not represented. 
IGNEOUS ROCKS.

LAVAS.

The whole north end of the IIot Creck Range, beginning with a point a few miles north of Hot Creek, is, so far as known, composed entirely of volcanic rocks, ineluding both rhyolite and basalt. There has been much erosion since the ontpouring, resulting in the carring of considerable valleys and the formation of large guleh dumps (alluvial fans) at their mouths, exactly as in the case of the stratified rocks. In places, also, erosion has stripped away the npper layers of lava and ash and has exposed symmetrical volcanic cones, which have been preserved by this protecting covering. Pl. V, $B$, is a photograph of such a cone. The number of these small cones and the abundance of ash, together with the thinness of the lava sheet, show that the volcanic rock in this region eame from many separate explosive rents.

In the neighborhood of Hot Creek, as before stated, the eastern half of the range contains a considerable area of Silurian rocks. Ilowever, rhyolite is found at the extreme eastern base, and the whole western half of the mountain at this point is composed of several thousand feet of the same rock. From here to the southem end of the range the western part is of volcanic, while the eastern half is mostly stratified. At the southern end the rhyolite mantles around to the east to join the lava of the Kawich Range.

\section{STRUCTURE.}

In Hot Creek Canyon the Silurian rocks form an anticlinal fold, broken by two or three normal easterly dipping faults. The first of these faults oceurs at the eastern end of the canyon, and by it the strata, including the Enreka quartzite, are down-faulted to the east 200 or 300 feet. This fault was also noted in the first canyon sonth of Hot Creek. Three miles farther west oceurs a second parallel fanlt. This fault has a rertical separation of about 1,000 feet, as marked by the Eureka quartzite, upthrown on the west. (See fig. 7.)

From Hot Creek to the southern end of the range the structure was not earefully examined, but for nearly the whole way the limestones can be seen to dip in general westerly at an angle of from $15^{\circ}$ to $20^{\circ}$. It is probable that this dip represents the westerly limb of the anticlinal fold exposed in Hot Creek Canyon.

\section{ORES.}

Along Hot Creek Canyon are some vertical zones in which rich pockets of ore are said to have been found. These zones are apparently ancient channels of the hot springs, which still exist. South of this point the rocks are more or less mineralized all the way to Tybo, where there are some important ore deposits. 
GEOLOGY OF NEVADA SOUTH OF 40TH PARALLEL. [BULL. 208.

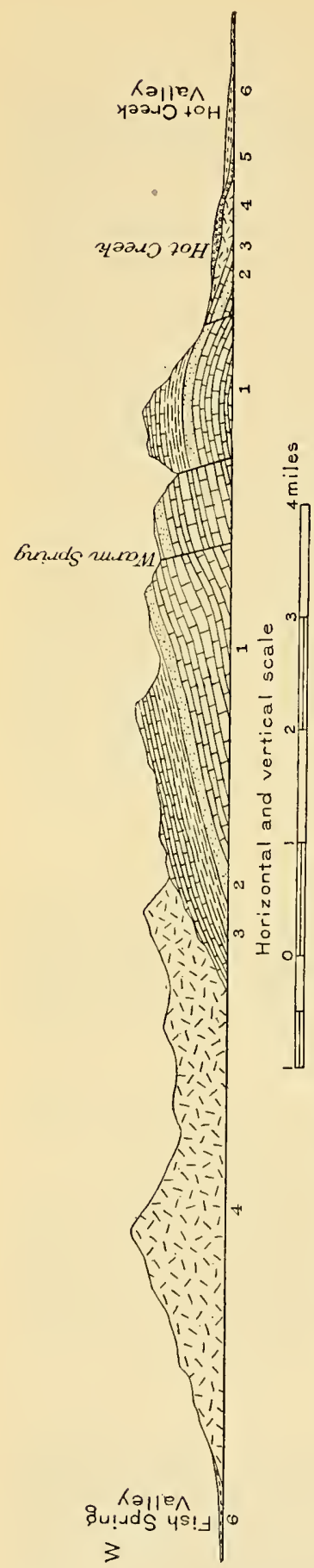

\section{PIÑON RANGE.}

The Piñon Range is mentioned in this report only because its sonthern end, which extends beyond the southern limit of the Fortieth Parallel maps, is included in the accompanying map. The writer did not visit this range, and the following slight summary is taken chiefly from the work of the Fortieth Parallel geologists.

TOPOGRAPHY.

The range consists of a single main ridge, which is conspienons north of the fortieth parallel and lies next west of the Humboldt Range. Farther south the Diamond Range comes in between the two. Near this point the Piñon Range becomes lower, and its trend changes from south to southeasterly, so that it swings around and joins the Diamond Range near Eureka.

\section{SEDIMENTARY ROCKS.}

In the neighborlhood of Pinto Peak there is exposed a thickness of about 14,000 feet of sedimentary rocks, ${ }^{a}$ comprising a section from the Cambrian up into the Carboniferous. Soutl of this the range is almost entirely composed of Devonian rocks. These Devonian rocks are continuous southward to the junction with the Eureka Mountains. ${ }^{b}$

\section{IGNEOUS ROCKS.}

VOLCANIC ROCKS.

Throughout most of the extent of the range various voleanic rocks are found, both at the east and the west bases.

"Arnold Hague, U. S. Geol. Expl. Fortieth Par., Vol. II, p. 554

b Arnold Hague, Geology of the Eureka district: Mon. U. S. Geol. Survey Vol. xx, p. 200. 


\section{STRUCTURE.}

As stated by Mr. Hagne, ${ }^{a}$ the range consists of open anticlinal and syuclinal folds. South of Pinto Peak the structure is anticlinal, the axis of the fold striking diagonally across the range S. 25 E., while the general trend of the range at this point is west of south. It is likely that the main anticlinal fold of the Diamond Range is the direct continuation of this anticline. Farther sonth, along the Piñon Range, this anticline gives way to an adjacent syncline, and farther south again the eastern limb of this syneline is cut off by the valley, so that only the western or easterly dipping limb remains. 'This portion of the range, therefore, has the aspect of being monoclinal.

A section made by Mr. Walcott, ${ }^{b}$ at Ravens Nest, just north of Pinto Peak, slows the structure as a faulted anticline.

\section{MONITOR RANGE.}

The Monitor Range is a belt of mountains about 70 miles long, lying next west of the Hot Creek Range. It has its northern end just south of the area shown on the Fortieth Parallel maps. The northern part of the range, up to within a few miles of Altoona Pass, has the aspect of a great west-sloping table which ends in a searp on the west, facing the valley. At Altoona Pass the range is narower and has a very sharp summit, with a steep descent on both sides. Farther south the range grows lower and is broken by frequent gaps, till it passes into low voleanic hills and dies out in the Ralston Desert.

Gilbert ${ }^{c}$ has observed a single spur of metamorphic rock on the west side of the range at its southern end. Otherwise the whole southern part of the range, as observed by $\mathrm{Mr}$. Gilbert and the writer, is volcanic. At Altoona Pass the lava is a siliceons rhyolite like that of the Hot Creek Range.

It is probable that this range has been formed by a series of volcanoes along a north-sonth line. The topography of the southeru part of the range (like that in the southern parts of the Toquima and Pancake ranges) is extremely irregular, consisting in part of interrupted mesas and ancient volcanic eones defaced by erosion. It is plain from this topography that the lavas have escaped from many different vents and have flowed together. Erosion of the lava has gone on to a considerable extent, inclicating the lapse of some time since the cessation of roleanic activity.

\section{WAHWEAH RANGE.}

The name Wahweah Range is applied to an irregular cluster of hills west of the southern end of the Piñon Range and just within the

\footnotetext{
a U.S. Geol. Expl. Fortieth Par., Vol. II, p. 5.1.

b. Mon. U. S. Geol. Survey Vol. XX, p. :

$c$ U. S. (reng. Surreys W. Ome Hundredth Mer., Vol. 11I, p. 121.
} 
northern limits of the aceompanying map. It was not visited by the writer, and the following brief characterization is taken from the reports of the Fortieth Parallel Survey:

The range is about 30 miles long and at its northem end consists mainly of granite, together with a heavy body of quartzite, which was referred to the Ogden Devonian on lithologie gromds, there being no fossils. The sedimentary rocks are here flanked by flows of volcanics, which farther south mantle over the stratified roeks and constitute mosi of the surfaee, exposing the underlying Paleozoic only in patehes. ${ }^{a}$

\section{TOQUIMA RANGE.}

The 'Toquima Range is situated next west from the Monitor Range. It has a trend a little east of north and a total length of about 80 miles. At its north end it passes into the level desert east of Austin, and its south end is situated sonthwest of Belmont, on the borders of Ralston Valley. The San Antonio Mountains are an irregular slump, soutl of the Toquima Range, and are separated from this range by a gap only a few miles wide. They are surronnded on all sides by detritus-covered plains.

\section{TOPOGRAPHY.}

The Toquima Range has comparatively great reliet. In generâl it consists of a single ridge of moderate breadth. At its sonthern end, near the town of Belmont, this splits in two, the main ridge trending a little west of south toward the San Antonio Mountains, while a minor one diverges and runs in a southeasterly direction into the Monitor Range. Between the two ridges is a low valley, filled with Pleistocene detritus.

The range is essentially volcanic, but in places is exposed a core of Paleozoic rocks beneath, indicating that here, as in the Hot Creek Range, the Antelope Mountains, and others, there existed a distinct range of Paleozoic rocks before the lava effusion, which has now aImost completely masked the stratified rocks and given the range the aspeet of being primarily voleanie.

\section{SEDIMENTARY ROCKS.}

The range was crossed by the writer only at one point. His ronte lay from the town of Belmont, aromnd the southern end of the range, along the road to Cloverdale. Along this route no stratified rocks could be seen in the range. North of belmont all is apparently volcanic. This impression has been confirmed by reconnaissance notes made by Messis. Gilbert ${ }^{b}$ and Emmons. ${ }^{c}$ Mr. Emmons suggests that

a U. S. Geol. Expl. Fortieth Par., Vol. II, p. 566.

bU. S. Geol. Surv. W. One Hundredth Mer., Vol. III, p. 121.

$c$ U. S. Geol. Expl. Fortieth Par., Vol. IlI, p. 393. 
the core of the range some distance north of Belmont may be composed of stratified rocks, but the first point where they have been observed is just east of Belmont, where occurs a series of black limy slates and gray finely erystalline limestone, banded black and white, and often siliceous. The formation is preeminently a slaty one and has often the aspect of a schist. This aspect is due to metamorphism, occasioned by certain siliceous dikes of the granitic family. One great dike is half a mile wide and runs in a north-sonth direction. Near its junction the shaly limestones become transformed into jasperoid, and in places by the development of mica the rock passes into mica-schist. Some of the jasperoid is also schistose, and contains small bunches of red and yellow metallie oxides, which give it the aspect of a knotted schist.

The stratified rocks here are tilted at high angles. Where olserved by the writer they were mostly vertical, but Mr. Emmons found a general easterly dip.

In the slates Mr. Gilbert ${ }^{a}$ found graptolites, which referred the rocks to the Silurian age. According to Mr. Wralcott," the rocks probably correspond to a part of the upper Pogonip formation of Eureka. $M r$. Gilbert ${ }^{c}$ estimates the apparent thickness of the stratified series at Belmont at 4,000 or 5,000 feet.

On the road leading from Belmont sonthwest toward Cloverdale the same series of strata is found at the eastern base of the main ridge. The chief rock is compact limy black slate, often metamorphic and schistose, corresponding closely with the rocks just east of Belmont. The metamorphism is evidently, as in the former case, connceted with intrusive masses of granite and rhyolite. By these the slate is sometimes transformed into an unsheared jasperoid or to a quartz-schist (the latter often containing actinolite and staurolite) and sometimes into highly erystalline mica-schist. A mile south of the most northern outerop found the shales are overlain by abont 200 feet of massive white quartzite, which is probably the Eureka formation. The quartzites and underlying beds are exposed south of here for some distance till they disappear under Pleistocene detritus on one side and volcanic rocks on the other. Farther southwest, however, at the spring, is found another small patch of the schistose slates eapped by the quartzite. This patch is surrounded on all sides by rhyolites, and is chiefy altered into jasperoid seamed with iron.

Looking eastward from the eastern base of the main ridge a portion of the minor ridge which runs sontheasterly from Belmont is seen to be composed of stratified rocks similar to those just deseribed. Apparently the schists and the overlying white quartzite can be recognized. 
IGNEOUS ROCKS.

LAVAS.

The whole northern part of the Toquima Range appears to be covered up by great flows of rhyolite. Just east of Belmont the foothills bordering the area of stratified rocks are composed of rhyolite running out to the north toward the main mass. Rhyolite is also found in large quantities southwest of Belmont. This area stretches north and, growing broader, joins the great mass which covers the northern part of the range. To the south also it appears to stretch across the gap to the San Antonio Monntains. Similarly, the rocks of the minor ridge which runs southeast from Belmont are mainly rhyolites, forming a continuous body with the rhyolites of the Monitor Range.

DIKE ROCKS.

Near Belmont there is a considerable development of coarse-grained granitic rocks. In several cases these are fonnd to be intrusive into the stratified rocks. A mile south of Belmont is an exposure of coarse granite-porphyry with sparse biotite and numerous Iarge orthoclase phenocrysts from 2 to 4 inches long. This may be continuons with the great dike before noted as running north and south just east of Belmont and having a width of half a mile.

The rocks of this dike, however, are different, being finer grained and in general more siliceous. They consist chiefly of quartz and feldspar. In some places the rock becomes mostly quartz; in others mainly feldspar. Quartz veins are abundant, irregular, and segregational, and evidently are the results of crystallization contemporaneous in a general way with the crystallization of the rest of the rock. Biotite is often sparsely present, and in some places the rock contains considerable muscovite and even passes into muscovitic quartz veins. Thin sections of the rock examined show in one case a fine-grained biotite-quartz-monzonite; in another case siliceous muscovite-biotitegranite, peculiar in having certain areas entirely of quartz. This rock is evidently closely related with another which is essentially composed of quartz and muscorite, with a little albite. This is a variation of the muscovite-biotite-granite, in which muscovite has largely taken the place of feldspar. The distinction between this type and the micaceous quartz reins which occur in elose connection with it, is not sharp ${ }^{a}$.

\section{STRUCTURE.}

The Silurian shales which oceur just east of Belmont have a strike of N. $35^{\circ} \mathrm{WV}$, and change from vertical to a generally easterly dip. Southwest of Belmont, on the eastern side of the main ridge, the same

aJ. E. Spurr, Quartz-muscovite rock from Belmont, Ner:: Am. Jour. Sci., 4th series, Vol. X, 1900, p. 351 . 
rocks have a general north-south strike and a westerly dip of $20^{\circ}$. The two locations, therefore, may be on the two limbs of an anticlinal fold. The further structure of the stratified rocks is concealed beneath the lavaflows.

\section{ORES.}

In the vicinity of Belmont there has been considerable ore deposition, which in the time of Nevada's mosperity made the region one of comsiderable watth. It present the mining industry is perfectly dormant. During the period of activity the region was destribed hy Mr. Emmoms." According to him the ores oceur generally in white quartz veins, often sereral feet in width, and consist principally of stetefeldtite (an algentiferous ore of antimony) with which is anmbined lead, silver, copper, and irom. The metallic minerals are scattered throngh the quartz in bunches or lisseminated partieles-rarely in banded form. The reins are fonnd eutting the Silurian shales and limestomes, and frequently are close to the intrusive granitiv dikes.

It appears to the writer that there is a genetie connection between the intrusive rocks and the metalliferous quartz veins of this district. $b$

\section{TOYABE RANGE.}

The Toyabe Range lies next west of the Toquima and extends sunthward about the same distance. To the morth, however, it has a greater length, ruming along the western border of the desertinto which the Toquima Range merges at its northern end. Tluns the entire length of the Toyabe Range is about 100 miles. It has a miform northnortheast trend.

That portion of the Toyabe Range which lies north of Austin has been included in the general maps of the Fortieth Parallel Survey. From Austin sonthward nearly to the sonthern end of the range, the mountains lave been made the subject of a speeial study by Mr. Emmons. ${ }^{c}$ The writer observed the range at its extréme southern end, and also its western base, along the valley which separates it from the closely adjacent Reese River. Rauge.

\section{TOPOGRAPHY.}

The topograply of the Toyabe Range is marked by features of considerable contrast, the mountains being sharp and high and the intervening canyons deeply cut. Throughout most of its course the range consists of a single ridge in its central portion. The sonthern ands of this range and of the Reese River Range converge until they almost unite.

The sonthern part of the range is essentially volcanic: while the rest is composed chiefly of granite and Paleozoic strata. The erosion 
of the lavas appears to have been quite as profound as that of the stratified rocks, showing that a considerable period has elapsed since the effusion of voleanic material.

In the valley which separates the southern end of the Toyabe Range from the corresponding portion of the Reese River Range there is a high divide, separating the north-flowing drainage of Reese River from that which flows south into the desert plain at Cloverdale. The south-flowing drainage runs in a canyon cut into the bottom of the valley, with rhyolite walls which go up at angles of from $45^{\circ}$ to $65^{\circ}$ to heights of 700 or 800 feet. At its bottom is a level floor covered with wash and sagebrush, and in the center of this floor is an arroyo 5 or 6 feet deep. At Cloverdale this bottom is one-quarter of a mile aeross, while 7 or 8 miles up it is barely 30 yards. The stream which flows in this canyon is derived from a spring. This case is like one described in the Snake Range region.

Another noteworthy feature of the erosion of this range, aceording to Mr. Emmons, is the oceurrence of basins at the heads of some of the canyous, which basins, he infers, were formerly oceupied by glaciers. At the mouth of one of the eanyons Mr. Emmons ${ }^{a}$ found glacial strix, which strengthened his belief. On most of the Great Basin ranges, as is well known, there are no marks of glaciation.

\section{SEDIMENTARY ROCKS.}

CAMBRIAN.

All the stratified Paleozoic strata of the Toyabe Range were mapped by the Fortieth Parallel geologists as Carboniferous, sinee Carboniferous fossils were the only ones found in the series. These occurred in limestones. Beneath the limestones was a thick series of slates, which were regarded as the same as those in the Toquima Range near Belmont. The subsequent finding by Mr. Gilbert of fossils in the Belmont slates determined them as Silurian. Beneath these slates, in the 'Toyabe Range, Mr. Emmons has deseribed a series of eompact white quartzites with some thin beds of white granular limestone, the series being several thousand feet thick. The quartzites underlie the slate series in apparent conformity, and outcrop in places along the eastern face of the south half of the range.

Farther nortl, beyond Austin, the high mountain called the Dome has been described by Mr. IIague ${ }^{b}$ as consisting of nearly white quartzite beds, which seem to be bent into a broad anticlinal fold. These ale overlain by beds of siliceous and argillaceous slates, and these by compact gray limestones. This is evidently the same series as described by Mr. Emmons. The thickness of the quartzites is not estimated, but must be great. 
No fossils were found in these quartzites, but in the Eareka section no such quartzite exist except that of the basal Cambrian; and the position of this series in the Toyale Range above probable Silurian slates strengthens the belief that it also is Cambrian.

\section{SILURIAN.}

As before noted, Mr. Emmons has described, overlying the heavy quartzites, an estimated thickness of 7,000 feet of limestone shales, with siliceous clay slates, locally metamorphosed into schistose rocks. Mr. Emmons regarded these slates as the same as at Belmont. In these latter rocks Silurian fossils have since been found. In the Eureka section the thickness of the Silurian is estimated at 5,000 feet.

This slate series occupies the central portion of the range, the general structure being anticlinal.

\section{DEVONIAN.}

Whether or not the Devonian exists in this range is not certain. The presence of Carboniferous and probable Silurian makes it seem very possible that the Devonian also comes in, although it has not been recognized.

\section{CARBONIFEROUS.}

Overlying the slate series which has just been referred to the Silurian, Mr. Emmons ${ }^{a}$ has described a compact dark-blue limestone which lies conformably upon the slates and is exposed on both flanks of the range on the two sides of the general anticlinal fold which is the chief structural feature. In this limestone. Mr. Emmons found Fusulina cylindrica and Syringopora.

\section{TERTIARY.}

Near the northern end of the range Mr. Hague ${ }^{b}$ has described, beneath rhyolite, beds of voleanic ash which, although without deterininable fossils, he referred to the Miocene. These beds are older than the rhyolite and have been disturbed, since their deposition, by the intrusion of igneous rocks, so that they underlie unconformably supposedly Pliocene strata, which are younger than the rhyolite.

\section{IGNEOUS ROCKS.}

A considerable portion of the Toyabe Range is made up of granite and volcanic rocks.

$$
\text { GRANITE. }
$$

Mr. Emmons ${ }^{c}$ has described five bodies of granite, all intrusive int? Paleozoic strata. The rocks vary somewhat in texture and composition, but are generally markedly siliceous, being characterized by a 
large proportion of quartz, an alnost entire absence of hornblende, and a small proportion of mica. Associated with the granite are finegrained dikes.

\section{RHYOLITE.}

Volcanic rocks occur at intervals along the flanks of the range, but the most important mass is at the sonthern end, where for 30 miles it completely conceals the granite and the stratified rocks.

Anong the volcanic rocks, rhyolite is the only one that has any very wide distribution, so far as observed. Mr. Emmons notes that rhyolite oceurs in exceptionally large masses and is of comparatively uniform coarse texture, having a granitic appearance in the hand specimen. At the southern end of the range the present writer has studied the rhyolites, which are here associated with buffs. The general type is biotite-hornblende-rhyolite, similar to the lava which forms the southern end of the adjacent Toquima Range.

AUGITE-BASALT.

In the little valley which separates the southern end of the Toyabe Range from the Reese River Range there was found, near the head of the Reese River drainage, a small area of augite-basalt.

RELATIVE AGE OF THE IGNEOUS ROCKS.

As in the 'Toquima Range, the intrusive granites of the 'Toyabe Range and the rhyolites slow marked consanguinity in composition. Each is characterized by biotite as the chief ferromagnesian mineral.

The augite-basalt is deeidedly younger than the rhyolite, since it was poured out in a valley which has been deeply cut into the latter rock.

\section{STRUCTURE.}

According to Mr. Emmons ${ }^{a}$ the range owes its existence chiefly to a lateral compression, which has thrown the stratified rocks into north-south anticlinal and synclinal folds. In addition to this there has been another pressure, coming from a different direction, which has distorted and dislocated these folds. The main fold of the range is an anticline, which occupies the whole central part of the range. The axis of this fold has an extreme variation from northeast at its northern end to northwest at its southern. South of here, at Ophir Canyon, Mr. Eimmons noted a syncline, probably adjacent to the main anticline. This syncline, however, was probably formed by the intrusion of granite. T'o the north of the central part of the range, in the vicinity of Austin, another synclinal fold appears, which also scems to be connected with a granitic intrusion. Farther north, 
as stated, the structure of the high mountain called the Dome appeared to Mr. Hagne ${ }^{c}$ to be anticlinal.

ORES.

Formerly the ores of the Toyabe Range were of great economic importance, but with the decline of the mining industries of Nevada they have been almost forgotten. The principal mining region was in the neighborhood of Austin, but mines were found from here sonthward all along the range. Mr. Emmons has described many of the deposits, which in nearly every case consist of veins of white quartz carrying metallic sulphides in irregularly disseminated bunches and streaks. In the vicinty of Austin, the oldest mining district in the State, the veins are mostly in granite, and rich ores do not appear to occur in other rocks. In other parts of the range, however, the veins occur in the stratified rocks. Besides quartz as gangue mineral, manganese spar and calc spar were noted, while the metallic sulphides comprise proustite, pyrargyrite, stephanite, polybasite, tetrahedrite, argentiferous galena, zinc blende, copper pyrites, and iron pyrites. In some of the veins the chief silver-bearing mineral is a mixed sulphide of antimony, as is the case in the neighborhood of Belmont. The veins are often faulted.

As in the case with the ores at Behnont, there is probably an intimate connection between the metalliferous quartz veins and the intrusive rocks.

Bull. $208-03-7$ 
CH A P T E I I.

\section{RANGES OE WEST'CENTRAL NEVADA.}

\section{REESE RIVER RANGE.}

The Reese River Range lies next west of the Toyabe Range, from which it is separated only by a narrow north-south valley at its southern end. From here it extends in a direction a little east of north about 100 miles into the area of the Fortieth Parallel surveys. Farther north the same general line of elevations is continued in the Shoshone Range.

\section{TOPOGRAPHY.}

So far as observed, the Reese River Range is composed entirely of igneous roeks, and the forms produced by erosion have therefore a certain uniformity. The summits show peaks which resemble remnants of ancient voleanic cones, and the valleys which furrow the flanks are deeply eut.

The valley which separates the Reese River Range from the Toyabe Range at its southern end has cousiderable interest. Its broad rounded form, as contrasted with the sharp incision of the lesser mountain valleys, shows that it has not been produced since the effusion of the lavas, but existed previously; yet the bottom of the valley consists of an unknown thiekness of lava, similar to that of the mountains on both sides. Subsequent to the period of effusion, erosion has formed deep gorges in the valley bottom.

Fifteen miles north of the southern end of the Reese River Range there is in the valley a divide which separates the northward-flowing drainage of Reese River from that which runs south. The southwardflowing drainage is in a canyon which is eut below the main valley floor 700 or $^{\circ} 800$ feet. $^{a}$ On the north side of the divide, the descent is shar'p into a broad, V-shaped valley ent in the rhyolite. Farther north, where the mountains diverge, the valley suddenly widens, and at the same time the topography of the base of the mountains on both sides changes, a broad, gently sloping plateau taking the place of the irregular hill topography of the higher valley. In the middle of this platean the valley in which the uppermost drainage of Reese River flows is several miles wide. 


\section{IGNEOUS ROCKS.}

So far as seen, the range is composed mainly of great masses of rhyolite, similar to the lava which makes "1) the southern end of the Toyabe Range. Along the eastern base of the mountains, at their sonthern end, are abmulant deposits of white volcanic ash. The eruptions which poured out the lava must, therefore, have been of an explosive nature.

In the valley between the Reese River Range and the Toyabe Range, at a point southeast of Ione, a flow of augite-basalt was found. On the opposite side of the range, in the vicinity of Ione, there is a considerable body of the same rock.

On thr edge of the desert valley, 1 or 2 miles west from Ione, there is a basic lava which appears, npon microscopic examination, to be biotite-andesite.

The low ridges rumning sonth from Cloverdale to the Monte Cristo Mountains are mainly flat rolcanic mesas. As seen from the vicinity of Ione, the Reese River Range for 10 or 15 miles north is evidently volcanic, and is probably mainly so up to the junction of the Fortieth Parallel map, where the Shoshone Range is represented as all rhyolite.

AGE OF LAVAS.

The augite-basalt on both sides of the range is plainly younger than the rhyolite, and appears to lie against the flanks of the hills eroded from it.

\section{ELLSWORTH RANGE.}

The name Ellsworth Range is here applied to the extreme southern end of a series of rather disconnected ridges which farther north are known as the Desatoya Monntains. This southern end, so named from the decayed mining camp of Ellsworth, is narrow, and consists of a single ridge which reaches a moderately great altitude.

In general the range seems to be composed of an ancient series of volcanics and derived tuffs, with limestones. These are cut by dikes and are capped and often entirely hidden by late volcanic flows.

\section{SEDIMENTARY ROCKS.}

The range was crossed by the writer between Ellsworth, on the east side, and Downieville, on the west. On the road some miles west of Ellsworth is a comparatively small outerop of white granular limestone, consisting of loosely cohering calcite crystals, which give a granular appearance not unlike that of sandstone. This rock is associated with an altered green rock of probable igneous origin, which is cut by siliceous dikes and is frequently mineralized. The only specimen of the green rock examined turned ont to be made up of epidote, quartz, and calcite, all probably secondary and resultant 
from alteration accompanying the introduction of the metallic sulphides which are frequently found disseminated in the rock.

On the summit of the pass, separated from the locality just mentioned by a shect of overlying basic lava, there is found, immediately beneath the volcanic rock, a dense sandstone or tuff, which on microscopic examination is found to consist of rounded quartz grains and altered feldspar fragments. 'This tuff eontains oceasionally angular fragments of lava and also doubtful plant remains.

From here to the foot of the comparatively steep scarp which oeeurs along the western face of the range, there is a vertical distance of nearly 2,000 feet. The section shows a single rock series, all probably of igneous origin. The rocks are reddish or greenish, often trap like and nearly always contain abundant angular fragments of lava, giving the appearance of a breecia. Rock having the appearance of red sandstone is common, but when examined nnder the microscope this is found to consist chiefly of highly altered feldspar fragments, with some calcite and epidote, the whole being stained with iron oxide. It is probable, therefore, that this roek is also a voleanic tuff. More abundant than this apparent red sandstone is a dense, greenish-looking rock, which microscopic examination shows to be probably a hornblende-biotite-syenite-porphyry. Below the ehief mass of this igneous rock there is again found a great thiekness of feldspathic tuff, which is highly colored in the hand specimen. Under the microseope the tuft is seen to be made up of rounded and broken fragments of feldspar in a kaolinic matrix, the whole colored by iron oxide. Below this again there is found white volcanic tuff, resembling ash, but containing some rounded, apparently waterworn, grains.

The dip of this series of igneous rocks and tuffs seems to be in general to the west, althongh the folding on a small scale is considerable.

At the base of the abrupt mountain scarp is found a moderately thin-bedded siliceous limestone, without fossils. The general strike is north and south, and the dip $20^{\circ}$ to $30^{\circ} \mathrm{W}$. This rock is found continuously to the end of the foothills at Downieville, where darkblue limestone alternates with beds of white and gray granular limestone or marble.

In the whole series exposed in the Ellsworth Range no fossils were found, exeept in the limestone just east of Downieville, where they were too poorly preserved to warrant collection.

The marble or white granular limestone at Downieville resembles that described on the east side of the mountain, above Ellsworth. In both places there is a north-sonith strike. The dip in the oceurrence near Ellsworth is an easterly one of $4^{\circ}$, while near Downieville it is westerly, averaging $20^{\circ}$ or $30^{\circ}$. It may be, therefore, that the two occurrences are on opposite sides of an anticlinal fold. If this is the case, then the thick series of interstratified igneous roeks and 
tuffs which eonstitutes the core of the mountain lies beneath the limestone series. The volcanic series must be at least 2,000 feet thick, the limestone series hardly less.

If we had no other data than the preceling we would hardly be able even to snggest the age of the rocks. We have, however, from the researehes of the Fortieth Parallel geologists, in the region not far north, results which may help us in correlating. In this same range near New Pass Peak, abont 60 miles northeast, are 'Triassic strata which $\mathrm{Mr}$. Emmons has described in the following terms" :

The lowest exposures show strata of a greenish, somewhat cherty quartzite. Above these, forming the summit of the ridge, is a breccia-like conglomerate. made up of greenish and purple cherty fragments. with a red cement, overlaid by a thickness of about 1,000 feet of qnartzite and conglomerate, weathering with a peculiar yellowish-brown earthy surface. On the western slopes, immediately underlying the limestones, is a bed of purple, argillaceons roofing slate. As exposed in Ammonite Canyon, there lies conformably above this a thickness of 1.000 to 1,500 feet of dark grayish-blne. compact. earthy limestones of the Star Peak gronp. which lithologically can not he distingnished from the Carboniferons limestones. At the contact of the limestones with the quartzites is a band of yellow calcareous shales.

The underlying greenish cherty quartzite and breceia-like conglomerate with red eement, described by Mr. Emmons, recalls the central mass of tuffs and volcanie roeks near Ellsworth, while the overlying, dark grayish-blne limestones are similar to those near Downieville. Immediately above the limestones Mr. Emmons found abundant Triassie fossils in a series of shales which were not observed in the Downieville section

The lower of the two series at New Pass Peak has been correlated by Mr. King with the Koipato formation, and the underlying limestone with the Star Peak formation, both formations occurring in the Triassic of West Humboldt Range. Concerning the Kioipato in the West Humboldt Mountains, Mr. King writes that at the base it consists of a vast thickness of quartzitic and argillaceous beds. These purely sedimentary rocks are observed to pass laterally into a rock which in hand speeimens resembles an ermptive rock.

This whole series contains no distinct beds of limestone, and wherever analyzed is remarkably free from carbonate of lime. Its lower limit is nowhere seen and, owing to the disappearance of the strata planes nnder extreme metamorphism, there is no possible mode of arriving at its total thickness. The npper limit, however, is sharply marked by an abrupt transition from the schists into a body of dark carbonaceons limestone. To this whole underlying group of schists and porphyroids we have given the title Koipato, from the Indian name of this range. ${ }^{b}$

Allowing for some slight difference in interpretation, Mr. King's characterization of the Koipato formation applies to the rocks on the western face of the range between Ellsworth and Downieville. Mr. King believed that the transition from sedimentary argillites to 
igneous rocks resulter from metamorpinism, while in the case of the rocks near Ellsworth those which possess igneous structure are almost without doubt ancient voleanies, which pass above and below, and probably laterally, into shales, conglomerates, and water-laid breccias derived from these or similar igneous rocks. The whole series therefore is conceived to represent the products of a period of ancient voleanic activity.

The series is more indurated, altered, and oxidized than any of the Tertiary roleanie series, and no similar rocks are known in the Paleozoic of Nevada. Their correlation with the established Triassic formations is therefore plansible.

\section{IGNEOUS ROCKS.}

The oldest igneous rocks of the range are those just described as interstratified with the tuffs of the great ancient roleanic series. The only specimen examined is probably a hornblende-biotite-syeniteporphyry.

Next younger than these ancient, volcanics come siliceous dikes, which are well exposed on the eastern face of the-range, near Ellsworth. The most easterly outcrop encountered is an alaskite-porphyry ${ }^{a}$ containing feldspar phenocrysts which are sometimes as much as $4 \mathrm{or}^{\circ} 6$ inches long. This resembles the granitic rock described south of Belmont. It is cut by several narrow dikes of finer-grained rock having the same composition, but not porphyritic. These siliceous dikes are intrusive into metamorphosed green rock just west of Ellsworth, the siliceons rock entting the other in numerous dikes.

Covering the ancient volcanic rocks and the later alaskite dikes there is found, ocenpying the center of the monntain between Ellsworth and Downieville, a bed of roleanic ash. Above this, forming the crest of the range and constituting all the high peaks, is a massive, columnar-jointed volcanic rock. A specimen of this proved on examination to be hypersthene-alentite. ${ }^{b}$ In the western foothills, near Downieville, is also probably a patch of similar, comparatively young voleanic rock, and north of Downieville the low limestone mountains are succeeded after a few miles by a chain of lower hills, which are, in part at least, volcanic. These extend northward at least 10 or 15 miles. At the southern end of the Desatoya Range, as mapper by the Fortieth Parallel geologists, the rocks are all volcanic, enveloping the Triassic strata exposed in the region of New Pass Peak.

\section{STRUCTURE.}

Apparently the main structure of the range is anticlinal, the ancient volcanic series constituting the eore, from which the overly-

\footnotetext{
a Alaskite is a general name proposed for rocks consisting essentially of quartz and alkali feldspar, without essential ferromagnesian minerals. J. E. Spurr, Classification of igneous rocks according to composition: Am. Geol. Vol. XXV, 1900, No. 3.

$\checkmark$ Alentite is the name proposed for a rock intermediate between andesite and basalt. J. E. Spurr, Classification of igneons rocks aceording to enmposition: Am. Geol., Vol. XXV, 1900, No. 3.
} 
ing limestones dip away on both sides. Inst north of Downieville the low limestone mountains are separated from the main range by a shallow and relatively broad valley. 'The strueture of these low mountains is anticlinal, and between this anticline and the one comprised in the main ridge is a syncline, in which the intervening valley lies.

\section{ORES.}

On both sides of the range there are ore deposits, once of great economic value, now largely abandoned. The mines near Ellsworth seem to be in the aneient igneous formation, and these old rocks show on exposed surfaces carbonate of copper and on fresh breaks copper pyrite. Between Downieville and the top of the momntains also there are ore deposits in the ancient voleanic series. At Downieville ores are found in the limestone, resnlting apparently from replacement of the rock by sulphides.

\section{PILOT MOUNTAINS.}

East of the Excelsior Range, on the other side of Soda Springs Valley, lies a short but comparatively rugged mountain range which has a north-south trend, changing to northwest in its northern portion. On the sonth the foothills of this range merge into those of the Candelaria Mountains, and are separated from the northern end of the Monte Cristo Mountains only by a narrow gap. On the north, the Pilot Mountains pass into the voleanic hills of the Gabbs Valley Range.

The highest portion of the range is Pilot Mountain, which lies just east of Sodaville. On the west face of this mountain there is a bold scarp (very likely a simple fault scarp), which rises from a point which has an estimated elevation of about 6,000 feet above sea level. Below this point there are immense guleh dumps, or alluvial fans, covering the other valley detritus, and reaching several miles westward toward the center of the valley.

\section{SEDIMENTARY ROCKS.}

EARLY TERTIARY OR MESOZOIC SERIES.

Most of Pilot Mountain is made up of stratified rocks. At the base is a series of gray roeks which, on account of a slight east-west flexure, transverse to the general north-sonth line of folding, passes down to the north and sonth so as to be covered by the valley detritus. These rocks are hard to identify in the field on account of their altered character, but microscopic study shows them to consist mainly of volcanic tuffs, generally coarse, sometimes fine and slaty. They grade into solid lavas. A specimen of one of the lava sheets on examination seems to be andesite. In the field no sharp line can be drawn between the tuffs and the slaty lavas. These rocks are eut by many dikes of siliceous granite. 
Overlying this gray tuffaceous series are reddish sandstones, shales, and conglomerates, whieh in turn are overlain by a considerable thickness of purer red sandstone and quartzite, whieh forms the summit of the momntains. An estimation of the thickness of the different roek series in this section gives 1,000 feet for the basal tuffaceous series, 1,000 feet for the sandstone, shale, and conglomerate series, and also 1,000 feet for the purer red sandstone series, making a total of 2,000 feet of red sandstone, shale, and conglomerate overlying 1,000 feet of the gray tuffaceous series.

Where the rocks immediately overlying the basal gray series were examined at the base of the mountain they were found to be red or white sandstone and quartzite, sometimes fine and calcareous, sometimes coarse and gritty. There is also much red sandstone conglomerate, indurated and squeezed. The pebbles of the eonglomerate seem to be entirely of quartzite and ehert. This reddish sandstone and shale series appears to extend northward several miles, until overlain by later rolcanie rocks. On the south it does not extend so far, being overlain in the foothills of the Pilot Range along the road between Sodarille and Columbus by later horizontally stratified sediments.

The upper 2,000 feet of red sandstone, shale, and eonglomerate is perhaps the same series as that deseribed as ocenrring in the Exeelsior Momntains, just across the valley to the west. The underlying gray tuffaceous series is not found in the Excelsior Mountains. Tithologically, some of the tuffs correspond to andesitic tuffs found in the folded Earlier Tertiary series of the Monte Cristo Mountains, 20 miles south of Pilot Peak. At the same time, the series has a very strong lithologic resemblance to the supposedly Triassic beds of the Ellsworth Range, into which the Pilot Mountains are ahmost direetly contimuous on the north.

Mr. II. W. Turner has recently reported Jurassic limestone and slate in the Pilot Mountains. " In a personal letter to the writer, Mr. Turner states that at the north base of the momntains he foumd abundant fossils in limestone, which were examined by Prof. J. P. Smith, of Stanford University, who pronounced them certainly Jurassic.

PLIOCENE.

On the southern side of Sola Springs Valley, horizontally stratified rolled gravels were found at an elevation of abont 5,.50 feet, and werè referred to the Pliocene sediments of Shoshone Lake. Similar sediments undoubtedly exist at the base of Pilot Monntain, but they have been covered up by the enormous subsequent Pleistocene gulch dumps, which form a belt along the foot of the mountain. The material in these dumps manifestly represents the larger portion of that removed from the gulches which cut back into the scarp of the moun-

"Geol. Soc. Am., Berkeley, Cal., Dec., 19n. Report in Am. Geologist, Feb., 1901, p. 13:. 
tain above. The erosion of these gulches is, therefore, mainly Pleistocene.

At the southern end of the Pilot Momntains, along the road between Sodaville and Columbus, is a considerable area of horizontally stratified fine silts and hardened clays, with some volcanic ash beds. 'This formation constitutes the divide between Soda Springs Valley and Columbus Valley, and reaches as high an elevation as 6,000 feet, where it is overlain by a sheet of basalt. These beds are evidently the result of deposition in a still body of water, and are correlated with the similar Pliocene beds described elsewhere in this region.

\section{IGNEOUS ROCKS.}

PLEISTOCENE OLIVINE-BASALT.

At the southern end of the range, overlying probable Pliocene sediments, occurs a thin-bedded, dark, vesicular lava, which proves to be olivine-basalt. From its occurence there is no doubt that this rock should be classified with the other Pleistocene basalts of the region.

GRANITIC ROCKS.

Pilot Mountain contains many branching dikes and irregular masses of intrusive granitic rock, similar to that across the ralley in the eastem end of the Excelsior Range. A typical specimen, examined microscopically, proves to be a biotite-granite. The intrusives seem to be chicfly confined to the base of the mountain, and not to have reached, in rery great quantity, the uppermost strata. The granite is accompanied by alaskite, ${ }^{a}$ and in the vicinity of these intrusions are ore deposits, as in the case of the east end of the Excelsior Momtains; and the ore has probably had a genetic connection with the igneous rock.

\section{MONTE CRISTO MOUNTAINS.}

The Monte Cristo Mountains are comparatively short and low. They have a general north-south trend, and extend from the Pilot Mountains on the north to the Silver Peak Range on the sonth, with a total length of about 30 miles.

\section{SEDIMENTARY ROCKS.}

On the road between Colmmbus and Silver Peak there is a comparatively low gap in the Monte Cristo Range. In this gap are found low hills of white shale capped by a porous bed which, examined microscopically, proved to be a calcareous andesite tuff. From this rock a collection of poorly preserved fossil shells was made, which Dr. W. H. Dall was not able to identify with certainty. Dr. Dall thought the forms suggested a fresh-water origin. He found a

$a$ Rock consisting essentially of quartz and alkali feldspar, without essential ferromagnesian miner:als. 
bivalve, which may be a Sphcerium, and a gasteropod that may be a Planorbis. The shales contain frequent leaves and occasional coal seams.

These sediments are capped by volcanic rocks. In the low pass above referred to the immediately overlying rock is a light-gray tordrillite. ${ }^{a}$ Above this comes andesite.

At the northern end of the Monte Cristo Range there appears to be a pateh of stratified rocks similar to those just described, the intervening space being completely covered by lavas.

This series has been examined somewhat carefully by Mr. H. W. Turner, who has named it the Esmeralda formation. He finds that it is shown at varions points in the Silver Peak Range, and that it comprises a considerable variety of sediments. ${ }^{b}$ According to him the series exposed aggregates at least 2,000 feet, and is composed chiefly of sandstone, with some shale. The top is made up of lacustral marls and white shales. Mr. 'Turner eollected from these rocks fossil shells, fish bones and scales, and dicotyledonous leaves, which were examined by Dr. J. C. Merriam, Prof. F. A. Lueas, and Dr. F. H. Knowlton. Dr. Merriam found that the fossil shells indicate an early Miocene or a late Eocene age for the beds, and Dr. Knowlton found that the plant remains indicate a Middle Tertiary age. The fish remains, so far as yet studied, do not seem determinate.

The writer has observed in the region south of here, notably in the neighborhood of Death Valley and in the Mojave Desert, upturned Tertiary sediments which he is inclined to correlate with the beds of the Esmeralda formation in the Silver Peak and Monte Cristo Momntains.

\section{IGNEOUS ROCKS.}

The greater portion of the Monte Cristo Mountains is covered by volcanic rocks. In general, dark hasic lava seems to overlie lightercolored siliceons lava.

\section{DESERT MOUNTAINS.}

The Desert Mountains form an irregular group which runs from the southern end of Mason Valley southeastward to near the northwestern end of the Gabbs Valley Range at the northern end of Walker Lake. In general these monntains have slight relief, althongh north of Mason Valley the peaks reach a considerable height. At the southern end the mountains change into low mesas of brilliant color.

These mountains are eomposed entirely of well-bedded rolcanic rocks. At the extreme northwestern end specimens examined prove to be biotite-hypersthene-andesite. Along the sontheastern end, near

\footnotetext{
$a$ Tordrillite differs from a rhyolite in being more siliceous and containing no essential dark minerals. J. E.Spurr, Am.Geol., Vol. XXV, 1900, No. 3. p. 230.

$b$ The Esmeralda formation: Am. Geol., Vol. XXV, 1900, p. 168.
} 
the head of Walker Take, the old baaches of the Pleistocene latke Lahontan may be traced.

\section{GABBS VALLEY AND GABBS VALLEY RANGE.}

Gabbs Valley is a broad, flat-bottomed basin, almost complotely surromnded by indegnlarly distributed voleanic mountains. The higher mountains to the sonth of the valley romstitute the Gabbs Valley Range, which rextends from Walker Take sombeastwated for abont 40 miles to the Pilot Momntains. The topogalphy of this range, as well as of the hills on the north siche of the valley, is eomparat ively primitive, the valleys being regular and in general not very deeply ent, recalling the elosion topogaphy of the supposelly Plineene late deposits of Pleasant Valley in the snake Range.

\section{SEDLIENTARY ROCKS.}

EARLIER TERTIART MARLA.

Near the center of the valley, just east of the low monntain spur which erosses it, and on the Reese River roal, there are low rirges of gray, stratified marl containing leaf remains, alternating with gravels and more solid eonglomerates. Some of the conglomerate eontains eomparatively abundant silivified wook. The conglomsate, when examined microscopically, proves to be voleanic. The pebbles are marle up in part at loast of spherulitic glass. Some pebbles eontain phenoerysts of felispar, of species indicating that the lava is andesitie, in a glassy matrix containing broken feldspar and biotite. Some of the shaly beds associated with the conglomerate are felitspathie tuff, mane np of fine fibrous matorial, with larow broken fragments of feldspar and some slureds of hiotite. These heds strike uorth and sonth and dip abont $8^{\circ} \mathrm{E}$.

No fossils were obtained from these borls. The locality is, however, at a higher altiture than that of the Pleistocene lake which, according to Professor Russell, "covered the lowest part of the valley just west of hrre. Also, the buls seem to show a general tilting, and sinee, according to Mr. King, the last marked folding in this area was post-Miocene, these beds are very likely pro-Plioene. They have the aspect of lacustrine marls. Tithologically, they coincidr with the descriptions given by Mr. King of his typical Truckee Miocene, which consists of sandstones, conglomerates, and tuffs at the base, with an enormous thickness of volcanic tuffs at the top, the whole series being as much as 2,000 or 3,000 feet thick. The typical Miocene localities of King are situated near here to the north. Therefore the beds monder consirleration are provisionally correlated with those described by Mr. King. They have also a general resemblance in their nature, derivation, degree of induration, and especially in their 
containing silieified wood, with the early 'I'ertiary series of the Silver Peak region, closely adjacent to the south. (See p. 185.)

PLEISTOCENE.

In the lowest portion of Gabbs Valley, west of the Tertiary marls just described, is a broad alkali flat or playa, eovered with smooth, hard mud. This was perhaps the bottom of a lake inclosed in the Gabbs Valley Basin. As mapped by Professor Russell, it was eontemporaneous with the great Lake Lahontan, but separated from it.

At the base of the voleanic mountains there is a continuous apron of detrital material sloping away at an angle of abont $3 \frac{1}{2}^{\circ}$ for a mile or two toward the middle of the basin. As in the case of the similar alluvial deposits investigated by Mr. Russell," these aprons seem to be older than the great Pleistocene lakes.

The effect of eolian action, of importance everywhere in the Great basin, is very conspicnous in certain portions of Gabbs Valley. The wind-blown sands have in many places acenmulated in considerable mass.

\section{IGNEOUS ROCKS.}

Most of the mountains surrounding Gabbs Valley, including the Gabbs Valley Range, are voleanic. These rocks represent a variety of species.

Just east of the hot spring in the valley the road passes throngh a gap in the mountains abont 1,500 feet deep, the sides of which rise at an angle of about $50^{\circ}$. The rock at this point varies from moderately fine to moderately coarse, but it is, nevertheless, always holoerystalline. It is massive and vertically jointed, yet has a distinct horizontal bedding, and a little northeast of here it seems to be underlain by ash. It is therefore probably effusive. A single specimen of this rock, examined microseopically, proves to be a hornblénde-biotitequartz-monzonite.

On the mountain ridge which separates Gabbs Valley from Walker Lake Valley the lavas which dip eastward into the former basin at angles of $10^{\circ}$ or more, in color gray or oxidized bright red, prove to be biotite-, hypersthene-, and hornblende-alentites and andesites. On all the momtains to the north of here, which were not visited, there appears to be a basal light-gray or red lava, which forms the highest peaks, underlying a dark-brown or black lava which forms the fringes of the mountains and sometimes constitutes a cone yet only slighty defaced.

Where the road crosses the extreme western end of the Gabbs Val- ley Range, overlooking Walker Lake, the lavas are mixed and the hills variegated, the colors being bright red, yellow, gray, greenish 
yellow, white, and black. In general a light-gray lava is overlain by dense black flows. The former proved to be biotite-andesite, while the latter is angite-basalt. A little farther, biotite-rlyyolite was found, apparently underlying the basalt.

\section{EXCELSIOR RANGE.}

The name Excelsior Range is applied to a short, rather irregular group of mountains which lies south of Walker Lake, and, unlike the most of the ranges of this region, runs in a general east-west direction, eutting oft the souther'n end of Walker Lake Valley and extending from the southern end of the Walker River Range eastward to Soda Springs Valley. The entire length of the range is only about 30 miles. The main range has to the north of it several high spurs which run off at right angles and connect with a lower east-west ridge parallel to the main one, farther north. To the sonth also a number of northsonth spurs connect the Excelsior Mountains with the Candelaria Mountains. The main range is terminated on the east by a bold searp overlooking Soda Springs Valley, corresponding to the westfacing scarp of the Pilot Mountains on the other side.

These mountains were erossed by the writer on the road between Hawthorne and Sodaville, which leads through Excelsior Flat.

\section{SEDIMENTARY ROCKS.}

\section{LIMESTONE SERIES (EARLY TERTIARY?).}

If one travels along the above-mentioned road from Walker River Valley eastward, he finds, after passing through a belt of lava which eonstitutes the foothills, an area of thin-bedded, shaly, sometimes compact, blue limestone. This limestone is overlain by a lava sheet, and near the contact is baked and silieified to a greenish or brown jasperoid containing segregated nodules of silica. The stratification is nearly horizontal, but shows local contortion and horizontal faulting, suggested breaking and shoving by the overriding lava sheet.

Near the eontact, partly in the blue shaly limestone, partly in the same rock transformed into jasperoid by the contact metamorphism, were found fossils. Mr. 'T. W. Stanton, of the National Museum, reports on these as follows:

Fossil lot No. 46, from the Excelsior Range, road between Hawthorne and Sodaville, evidently represents two distinct beds, one a hard brown siliceo-argillaceous rock and the other a dark-blue limestone. The former contains several specimens of a Corbula, another undetermined bivalve, and a very imperfect Gasteropod that may be a Natica or a Vivaparus, the generic character not preserved. These are probably not earlier than Cretaceous, and they may be Tertiary.

The blue limestone fragments yielded a small Neritina, a Hydrobia (?), an Astarte (?), and several imperfect specimens of two or three other small bivalves. These fossils have a Tertiary aspect. They are certainly not older than Cretaceous. 
In answer to a query as bo the conditions of deposition indicated by the fossils Mr. Stanton writes:

The fossils in lot 46 are either marine or brackish-water form, not fresh water. If I could be sure that the bivalve I have called Astarte (?) really belonged to that genus there would be no doubt that they are marine. The other genera recognized live in both salt and brackish water.

To the east this limestone forms a well-defined anticline, with a north-south axis, and with dips of $20^{\circ}$ to $30^{\circ}$ on both sides. Still farther east the limestone is again overlain by the volcanic rock which encircles this area.

In the bottom of Excelsior Flat, near jts eastern side, probably the same limestone series is found, but more altered and crushed and veined by dynamic action. Badly preserved fossils were collected from this rock, but could not be identified.

The thickness of this limestone series was roughly estimated at 2,000 feet.

SANDSTONE-SHALE SERIES (FAlLY TERTIARY OR MESOZOIC?).

Along the western border of Excelsior Flat is found a belt of red sandstone which underlies the lavas. This sandstone belt is continuous to the low mountains south of here, where it passes upward into a series of gray stratified rocks. Farther east the sandstone series, with the orerlying gray rocks, seems to overlie the probable Tertiary limestones which ontcrop along the eastern portion of Excelsior Flat, the older rock being apparently the core of an east-west striking anticlinal fold, and the sandstone series forming the northern limb. On the southern limb, which comprises the main ridge of the Excelsior Monntains, the bulk of the rocks seem, as viewed from a distance, also to belong to the stratified red sandstone and shale series.

Following the road farther east, the transverse spur which rums northward from the main ridge of the Excelsior Mountains exhibits the same east-west striking anticline. Along the axis a canyon has been ent through the spur, and here are exposed red sandstones, with much red, yellow, brown, and green dense siliceous shales. No fossils conld be found. The rocks here stand, in general, nearly vertical, and are crumpled and faulter. South of here the rocks have a sontherly dip, first steep, then shallowing, while to the north the rocks belonging to the same series have for a considerable distance a northerly dip, which afterwards reverses so that a body of underlying gray shale, which may belong to the probable Tertiary limestone series, comes into the visible section.

From the data above noted, we appear to have a series of red sandstones and quartzites, with some shales and conglomerates, having a ronghly estimated thickness of 1,500 feet. These are overlain by a series of red-gray sandstones, shales, and conglomerates about 2,000 feet in thickness, making a total of about 3,500 feet. These rocks 
seem to overlie the probable Tertiary limestones and are folded together with them. The exact contact of the two series, however, was not found. No such sediments as this sandstone-shale are known in the Paleozoie section, and therefore the rocks would, without any other consideration, at once be considered as Mesozoic or Tertiary. In the region just south of here a series of folded shales and tuffs has been deseribed by Mr. Turner" under the name of the Esmeralda formation and is probably Miocene, possibly reaching back into the Eocene.

This series, when observed by the present writer, struck him as resembling in a general way the thin sandstones and parti-colored shales of the Excelsior Range section, although the latter are distinctly more highly indurated and altered.

Rocks similar to the sandstone-shale series of the Excelsior Range form a large portion of Pilot Mountain, just to the east of here, across Soda Springs Valley. As noted in the description of the P'ilot Range, Mr. H. W. Turner found Jurassic fossils in some of these beds.

It is therefore not certain whether the sandstones and shales of the Excelsior Mountainș are Tertiary or Mesozoic, and they may be partly one and partly the other.

While the series of tuffs, sandstones, shales, and conglomerates of the Excelsior Range may possibly be the equivalent of the somewhat similar strata of the Esmeralda formation near Silver Peak, the limestone of the former locality is not represented in the latter. This limestone also separates itself from the probable fresh-water Esmeralda formation in that its fauna denotes a probable marine origin. In this respect, also, it seems to be different from the rest of the known Tertiary strata, which extend in a more or less continuons belt from this district sonth into the Mohave Desert, and the present aspect of our knowledge indieates that it represents a period during which conditions were quite different from those which followed.

PLIOCENE.

On the western side of Excelsior Flat the lava is underlain by a solid but friable deposit, consisting of ash and pumice, having the appearance of being waterlaid. This occurs at an elevation of about 5,500 feet. In the valley below and to the east of this are less consolidated, horizontally stratified gravels, containing pebbles of lava and reaching up nearly to the same elevation.

On the eastern flanks of the Excelsior Mountains, overlooking soda Springs Valley, there was noted, at an elevation of 5, 250 feet, horizontally stratified gravels and volcanic tuffs, lying unconformably against the folded Tertiary series and partially consolidated. The regular stratification of these deposits suggests that they are lake 
sediments, and they are probably to be correlated with similar sediments found all over the region north and west of here, which have been called Pliocene.

\section{IGNEOUS ROCKS.}

LAVA.

Along the road between Hawthorne and Sodaville, which passes through Excelsior Flat, there is, on the west border of the hills, a belt of finc-grained lava, which forms broad, slightly dissected mesas. A specimen of this lava proved to be pyroxene-olivine-basalt. It occupies a large area, inclosing the body of probable Tertiary limestone, which it overlies, and toward the east forms a considerable portion of the main ridge of the Excelsior Mountains, of the spurs which run north from it, and of the parallel east-west ridge with which these spurs connect. It overlies the probable Tertiary sandstones and shales and the stratified, water-laid tuffs and gravels of the Pliocene. Sonth of the main range the earlier 'Tertiary series is again overlain by slightly dissected lava, and this lava runs southward into the Candelaria Mountains, where a prominent peak has the aspect of a slightly denuded volcanic cone.

The fact that this lava overlies all the stratified rocks, even the supposedly Pliocene gravels, together with its very slight erosion, shows that it is very young, probably early Pleistocene. The composition of the lava bears out this reasoning, for it is probably to be correlated with the Pleistocene basalts described in other ranges. ${ }^{a}$

GRANITIC ROCKS.

As seen from Excelsior Flat, a considerable portion of the highest part of the Excelsior Mountains to the southwest consists of gray, rugged-weathering granitic rocks. At the abrupt eastern end of the main range the earlier Tertiary sandstone and shale series is contorted and apparently eut by granitic dikes.

\section{STRUCTURE.}

To the north of the main ridge, the general east-west valley, which is in part occupied by Excelsior Flat, seems to lie along the axis of an anticlinal fold with east-west strike. The main ridge lies on the southern limb of this fold, while the minor ridge lying north of the valley and parallel to the main one, is on the northern limb.

Northwest of Excelsior Flat the area of probably Tertiary limestone first described ${ }^{b}$ forms one of the north-south spurs which run at right angles to the main range. The structure of this spur is anticlinal, but the strike of the fold is north and south.

aJ. E. Spurr, Succession and relation of lavas in the Great Basin region: Jour. Geol., Vol. VIII, p. 636 .

$b$ See p. 109 . 
ORES.

There has been considerable mineralization in the Excelsior Mountains. On the west side, along the road traveled, there has been mineralization in the limestone near the contact with the overlying lava. Farther east the red sandstones are found to be bleached and to contain disseminated copper minerals. On the eastern end of the main range are ore deposits, associated with erumpling of the strata and probably with granitic dikes.

\section{RÉSUMÉ.}

The rocks of the mountains are probably Early Tertiary limestones, together with a series of sandstones and shales with some conglomerates. The relative age of the limestones and sandstone shales is uncertain. These two series were folded together. While the main folds trended east and west, a minor set had north-sonth axes. At about the same time came the intrusion of granitic rocks as dikes and larger masses; the ore deposition was also probably nearly contemporaneous. After this came leep and long-continued erosion, bringing about the present topography and followed by the formation of the Pliocene lake. Finally this lake receded and great sheets of basalt were poured out.

\section{CANDELARIÄ MOUNTAINS.}

The term Candelaria Mountains is here applied to an irregular group, reaching from the California-Nevada State line eastward to the Columbus Valley. It lies just north of the White Mountain range and south of the Excelsior Mountains.

\section{SEDIMENTARY ROCKS.}

CAMBRIAN.

Mr. F. B. Weeks, who visited the mountains in 1899, has informed the writer of the existence of a considerable thickness of quartzite and limestone (see Pl. I). No irlentifiable fossils were found.

\section{CARBONIFEROUS.}

On the road between Columbus and Candelaria there occur darkgray, nearly black, quartzites, and stretehed conglomerates, with some coarse sandstones and nearly white fine-grained chert. Mr. H. W. Turner has kindly supplied the writer with the following note concerning the discovery of Carboniferous fossils in this rock:

I am indebted to William Grozenger for information as to this locality, which lies 3 miles northwest of Columbus by the trail to Candelaria, at an elevation of about 4,900 feet. Similar fossils also occur in the gulch just north of this point at

Bull. 20S-03-S 
an elevation of about 5,200 feet. These fossils were referred to Mr. Charles Schnchert, of the United States National Mnseum, who reports that the collection contains two Carbonic species, a Productus and a Spirifer. Both are specifically undetermined at present. The Spirifer (apparently a new species) belongs to the S. comeratus section, fossils recognized as characteristic of the Upper Carbonic. The Productus is apparently identical with one from the region north of Mount Sliasta, in California, also associated with Upper Carbonic species. These forms remind one more of the Carboniferous fam found in the Shasta region than of the Carboniferous farther east.

\section{EARLIER TERTIARIES.}

Adjoining the Carboniferous roeks to the northeast, and probably overlying them is a comparatively small area of brown, yellow, sometimes purplish, limy and sandy shales, argillaceous fine sandstones, and thin-bedded brown and yellow aphanitic limestones. This series strikes $\mathrm{N}$. $65^{\circ} \mathrm{E}$., and dips $65^{\circ} \mathrm{NW}$. It is probably identical with the rocks of the Esmeralda formation a few miles to the south, in the southern end of the Monte Cristo Monntains. At one place the upturned edges of the stratified rocks are overlain by a thin sheet of siliceons rock, so glassy that the microscope does not show its true character, but it is probably rhyolite and susceptible of correlation with the rhyolite overlying the sedimentary rocks in the Monte Cristo Mountains.

PLIOCENE BEDS.

At the gap which separates the Pilot Monntains from the Candelaria Mountains, just north of Candelaria, occur certain horizontally stratified clays and sands which have already been mentioned, in describing the Pilot Mountains, as belonging to the group of Pliocene sediments.

\section{IGNEOUS ROCKS.}

Overlying the Pliocene sediments not far north of Candelaria, thin sheets of olivine-basalt were found (Pleistocene). South of here, overlying the stratified beds of the Esmeralda formation, were found the sheets of glassy rhyolite above mentioned. West of Columbus and Candelaria, a large part of the range appears to be eomposed of red and gray lavas overlying and often coneealing the sedimentary rocks. As seen from Sodaville, the northern part of this mountain group is also chiefly voleanie, the topography showing such smooth, mesa-like forms, and so little erosion that the rocks were considered as probably belonging to the Pleistocene lavas. A prominent peak in the central portion of the Candelaria Mountains has the aspect of a little denuded volcanic cone. ${ }^{a}$

a'These observations have been confir'med by Messrs. Turner and Weeks, who visited the range separately the same year as did the writer. Mr. Turner states that the hills north of Benton are also all lavas. 
WALKER RIVER RANGE.

The Walker River, or Wassuck, Range is a straight, bold ridge of mountains, rising immediately from the west shore of Walker Lake. It has a trend a little west of north and a length of abont 60 miles. It is separated on the north from the voluanic Desert Mountains by the Walker River Valley, and on the south it passes into the irregular Excelsior Mountains. Throughout most of its conrse the range is characterized by the comparatively gentle slope of the west side and a steep scarp on the east.

\section{IGNEOUS ROCKS.}

Almost all the rocks of the Walker River Range are igneous. Those on the steep eastern face are generally granular, and those on the rest side typical volcanics.

\section{GRANULAR ROCKS.}

Just west of the Indian agency at the upper end of WValker Lake, the rock of the mountains is chiefly a coarse-grained biotite-granite. Farther north, near the point where the road crosses the range, biotite-granite-aplite, of a distinctly more siliceous variety than the first, occurs in conjunction with great masses of alaskite-aplite.

On the road which crosses the range, at a point southwest of Hawthorne, the summit and greater part of the mountain range appears to be also of decomposed biotite-granite. Between these two localities the granite is probably nearly or quite continuous.

Underlying the biotite-granite, at the point first described, is a dark rock, specimens of which proved to be hornblende-quartz-syenite and biotite-hornblende-quartz-monzonite. The granite is shown by its branching dikes to be intrusive into the more basic rock. Both rocks are cut by dikes of alaskite, which grows very siliceous and runs out in places to nearly pure quartz.

In the cream-colored mountain of granite and alaskite around which the road turns in crossing the range, the alaskite is evidently younger than the siliceous granite, into which, however, it passes by transitional stages as regards its composition. The granite sometimes contains large feldspar phenocrysts, similar to those of the rock near Belmont and near Ellsworth.

At the pass southwest from Hawthorne, the biotite-granite which occupies the summit of the mountains is succeeded farther east by metamorphosed igneous rocks, probably altered by dynamic movements. These rocks lie along the face of a bold, eastward-facing scarp. As examined microscopically, they consist of aposyenite-porphyry, apogranite, and apoalaskite, with some biotite-rhyolite, which may be later than the others. These metamorphosed igneous rocks are confused with some highly altered limestones and quartzites. 
LAVAS.

On the west side of the eream-colored mountain which lies northwest of the north end of Walker Lake, on the road across the range, the granular rocks, already described, pass under and into gray and red voleanies, which dip $30^{\circ}$ to $45^{\circ} \mathrm{SW}$. away from the mountain. About the point where the granular rock gives place to the evident voleanies, specimens were collected, which proved to be alaskiteporphyry and tordrillite, the latter with a finely cryptocrystalline groundmass. Overlying these siliceous rocks was found angite-biotitealeutite. West of this point, near the summit of the range, the prevalent rock is biotite-andesite, containing many angular fragments of a darker lava. The whole western side of the mountains is voleanic.

IGNEOUS ROCKS SHOWING TRANSITIONS OF TEXTURE.

In a small butte (Mason Butte) which emerges from the Pleistocene valley deposits to the west of the northern part of the Walker River Range, a few miles south of Wabuska, an intersecting series of igneous rocks was studied. The butte presents the appearance of a typical voleanic rock, being distinctly and thinly bedded and of red and gray colors.

Upon examination the rocks are found to be in part granular and in part fine grained and porphyritic, the different textures alternating in conformable beds. Examined microscopically, the coarse-grained rocks are hornblende-biotite-quartz-diorites, while the fine-grained ones are hornblende-biotite-quartz-andesites. The chemical composition of the two rocks is also nearly the same. Sometimes the coarsegrained and the fine-grained types appear in the same bed, one apparently being formed at the same time as the other'; generally, however, the beds are separate.

The hypothesis adopted by the writer is that these rocks are the roots of old voleanic flows which have been exposed by the removal of the overlying portions of the lava throngh the erosion of Walker River, in whose valley the butte lies. The whole appears to have been an igneous mass in process of slow flowage, some streaks of which crystallized rapidly, with the texture of true lavas, while between them portions of the same magma crystallized more slowly, as grantular roeks. ${ }^{a}$

Facts suggesting similar transitions of texture were noted within the main Walker River Range, but are not described on aecount of insufficient evidence.

SEDIMENTARY ROCKS.

PLEISTOCENE.

Professor Russell has described the history ${ }^{b}$ and the sediments of the Pleistocene Lake Lahontan, an arm of which occupied the valley

a For a fuller statement of this problem see J. E. Spurr, Variations of texture of certain Tertiar'y igneous rocks in the Great Basin: Jour. Geol., Vol. IX, p. 586.

b Mon. U. S. Geol. Survey Tol. XI, 
of the present Walker Lake. The writer also observed these sediments as well as older stratified deposits, which reach higher up in the mountains. The line between the Pleistocene and the Tertiary has not been elosely drawn in this region, and probably a portion of those deposits older than the Lahontan sediments are still Pleistocene, but at present the writer will include nnder that head only the deposits of the lake described by Russell.

In the valley of Walkel Lake the depth of the Pleistoeene Lake Lahontan at its highest stage was 225 feet. At the upper end of the present Walker Lake the elevation is 4,120 feet above sea level, which would make the surface of Lake Lahontan at this point 4,345 feet. At about this altitude, as meastured by the barometer, the writer found a heavy terrace, and about 200 feet above this a still heavier one, the top of the main terrace being abont 4,600 feet high. These terraces are constructional and show a rude horizontal stratification. They are composed largely of gravels and huge bowlders from the adjacent mountains. At another point, farther north, the altitude of this same chief terrace was determined as 4,675 feet. On the opposite side of the valley, on the slopes of the Painted Mesa (which forms part of the Desert Monntains), corresponding deposits may also be seen, taking the form of inclined slopes or ancient beaches rather than of sharply cut terraces.

PRE-LAHONTAN SEDIMENTS.

About 100 feet above the heaviest terrace just mentioned is a lesser construetional terrace, and abont 400 feet higher there is on the mountains a rock-cut bench which is probably also a water line. This rock-ent bench is at an altitude of about 5,100 feet, or about 700 feet above the surface of the ancient Lake Lahontan, while the constructional terrace below it is abont 300 feet abore the old surface. Crossing the southern end of the range, coarse, horizontally stratified material, consisting of little assorted voleanic rock, is found to the summit, where it forms hills 400 or 500 feet high, reaching up to an altitude of abont 5,730 feet, or 1,385 feet above the surface of Lake Lahontan.

On the western side of the range, at the point where the road crosses dne sonthwest from Hawthorne, stratified gravels are found up to a height of 7,100 feet. These deposits seem to be water-laid. They are evidently pre-Lahontan, and if formed in a lake ocenpied a body of water which was the ancestor of the Pleistocene lake, but of rastly greater dimensions and probably of longer life.

From reasons entailed in the correlation of these gravels with others throughont the region these deposits are provisionally classified as Pliocene.

\section{SMITH VALLEY RANGE.}

The name Smith Valley Range may be applied to a low and narrow movntain ridge, which on the north merges with the Pine Nut Range, 
and on the south spreads ont broadly into a series of volcanic mesas, which connect farther south with a spur of the Sierras north of Lake Mono. The range as thus defined separates Mason Valley, on the east, from Smith Valley, on the west.

\section{IGNEOUS ROCKS.}

Smith Valley Range is essentially volcanic. At the northern end, where it merges into the Pine Nut Range, specimens of the lava, forming comparatively well-dissected momntains, are found to consist of hypersthene and biotite-andesite, with some biotite-dacite. Sonthward from here the range is evidently volcanic, but it was not examined closely except in the region of Dalzell Canyon, which separates the southern part of the range from the Sweetwater Mountains, farther west.

In Dalzell Canyon the oldest formation consists of granite and rhyolite, and is altered and jointed. Overlying this is prroxenehornblende-andesite, and still higher are comparatively slightly eroded mesas of more siliceous andesitic rock, or hornblende-biotite-latite.

On the road which cuts across the low southern end of the range east of Sweetwater, following the npper part of the East Walker River Valley, the siliceous andesite and latite fiows are succeeded on the east by more basic thin-bediled andesitic or basaltic lava, largely glassy. This overlies sands, clays, and conglomerates, which will presently be describer as probably Pliocene. It has flower into and dammed up the ralley eroded in the esrlier lavas. It is therefore the latest of all and is probably Pleistocene. Farther east this same glassy lava occupies a considerable area in the bottom of the broad Walker River Valley, and forms broal mesas on the flanks of the Smith Valley Range on the west and the Walker River Range on the east, and, reaching around to the south, forms a large part of the hills between the Walker River Valley and Mono Valley. At the sonthern end of Walker River Valley, a few miles north of Aurora, is a littledefaced volcanic cone of red lava, which probably belongs to the same epoeh. This has been called the Anrora Crater on the topographic map aceompanying Professor Russell's paper on Lake Mono. ${ }^{a}$ 'These lavas everywhere overlie the stratified gravels which occur in the sonthern part of the Walker Lake Valley, in the same manner as already mentioned.

South of here, in the basin of Lake Mono, Professor Russell ${ }^{b}$ has deseribed rarious lavas, including hypersthene-andesite verging upon basalt, and rhyolite, which are evidently Pleistocene. These lavas helong to the same class as those just described, and seem to correspond with the thin flows capping the Pliocene grarels near WVellington on the Sweetwater Range, and also to the thin flow of basalt which 
constitutes the latest volcanic rock in Eldorado Canyon in the Pine Nut Range; ${ }^{a}$ but in the distriet under immediate consideration we have a vastly greater amount of Pleistocene volcanic action than was observed anywhere else in the region.

\section{SEDIMENTARY ROCKS.}

Just south of Dalzell Canyon were found well-stratified arkoses and little-worn conglomerates, containing chiefly angular fragments. These seem to cover the whole of a broad upland valley, to its abrupt end at the base of the Sweetwater Mountains, at an elevation of something over 7,000 feet. As one goes southeastward from here, passing Sweetwater post-office and proceeding down the valley of Walker River where this cuts across the range, one finds, at an elevation of 6,500 feet at least, and below, well-stratified, washed, and assorted, horizontally or slightly cross-bedded sandstones, arkoses, and gravels. These rocks are often firmly consolidated, though friable, and resemble the sandstones near Carson, as exposed at the State prison. ${ }^{b}$ The pebbles in the gravels are evidently derived from the andesite which is the main rock of the Smith Valley Range. Farther west, on the slopes of the hills facing the main Walker River Valley, a section of these deposits 100 feet thick was examined. Near the bottom were found sandy clays, which may be in part water-laid voleanic ash. Farther up come hard gravels, the well-rolled pebbles comprising various varieties of hornblende- and mica-andesite. Above this comes a compact gray sandstone, also made up of volcanic débris and containing fragments of white decomposed pumice. Capping the sedimentary rocks and overlying them, with a considerable angle of divergence, comes a thin sheet of andesitic or basaltic lava with glassy base. The top of this section has an altitude of about 6,150 feet. A short distance away from this section the highest sandstone reaches an altitude of about 6,350 feet and is exposed as a simple bench in the mountains, the overlying lava having been eroded back from it. Along the northern slopes of the mountains which form the southern end of the Walker River Valley, northwest from Aurora, are continuous benches, the best marked of which can be little less than 7,000 feet in height. Below this are other sharp smooth benches of horizontal sandstone. The comparatively recent volcanic cone above referred to, lying northeast from Aurora, is benched up to 6,700 or 6,800 feet, but not higher. These terraces appear to grow somewhat higher to the south. The whole valley here is covered with the sandstones above described, which have been considerably eroded. At least 700 or 800 feet of this sedimentary series is exposed.

On the road which crosses the southern end of the East Walker River Valley and goes over the Walker River Range to Hawthorne, 
horizontally stratified gravels, apparently belonging to the same series as the sandstones above mentioned, occur, frequently overlain by glassy and slaggy antesitic or basaltic lavas, up to a height of 7,100 feet, where they give way to a fresl lava, above which all is deeomposed granite.

All these comparatively recent horizontal sediments are provisionally classed as Pliocene.

\section{PINE NUT RANGE.}

TOPOGRAPHY.

The Pine Nut Range lies immediately east of the Sierra Nevada, and has much of the bold irregular topography of that range. As contrasted with the monntains of the more arid regions farther east, it is distinguished by deeper dissection, affording more profound canyons and more abrupt cliffs. The eastern face of the range is steep, the western side in general less abrupt.

Wherever this range was visited, numerous springs were observed, and the dissection seemed to be largely the result of water derived from these sources. The springs seem to be arranged, in part at least, along north-south lines, whiclı are probably lines of fracture. These lines are deeper than the regions between, which stand up as ridges; but whether these ridges are directly due to displacement, or have been left as such by the erosion of depressions along the lines of spring water, is uncertain.

On the western side, between Dayton and Carson, the peculiarly wild and rugged topography is caused by the Carson River and its mountain tributaries which, in late Tertiary or Pleistocene time, have dissected the monntain and the adjacent platean-valley.

\section{IGNEOUS ROCKS.}

Nearly the whole mass of the range is igneous. The rocks were studied principally along two sections, one across the range southeast from Dayton and the other on the road between Wellington and Genoa.

In the eastern part of the first-mentioned section, in the lower mountains which here lie to the east of the main range and are connected with the northern end of the Smith Valley Range, chiefly andesitic rocks were found. The andesite contains different ferromagnesian minerals, including hornblende, augite, hypersthene, bronzite, and biotite. Occasionally biotite-daeite or quartz-andesite is foumd. Where erosion has cut deeply into the lava, coarser, denser, more massive, and more porphyritic forms are exposed. At the bottom of one of these canyons the lava is a fine-grained diorite-porphyry, while farther up it is hypersthene-bronzite-andesite with some dacite.

Farther west, on the eastern searp of the main range, occur gran- 
ular rocks. These, when examined microscopically, turned ont to be hornblende-biotite-granite, sometimes porphyritic, and alaskite. The same granular siliceous rocks are exposed nearly to the summit, and they ocen also on the westem side of the divide. Here they are overlain by hornblende-, augite-, and hypersthene-andesites.

About halfway down the mountains, in Eldorado Canyon, where the road leading to Dayton runs, there are hills of gently folded gravels and coarse clays, the gravels being derived almost entirely from the andesites. They are exposed best in the arroyos, where they are overlain unconformably by $S$ or 10 feet of stratified bowlders and soil, which represent the recent stream aceumulations. Farther down the canyon is a volcanic breceia with rounded andesite bowlders, probably water-laid. This breceia is followed by thin flows of slaggy white lava, which contains numerons included angular fragments of andesite; these flows are interbedded with ash. The present canyon has been worn down through this breceia, ash, and porons white lava deposit. In several places a thin sheet of basalt has been poured ont after the development of the present topography (fig. 8). This sheet

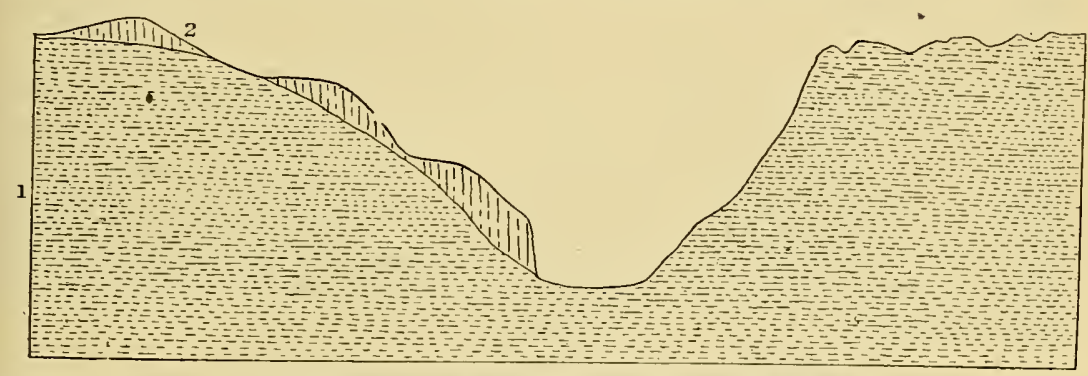

FIG. 8.-Section of Eldorado Canyon, Pine Nut Range.

1. Stratified rhyolite ash. 2. Basalt.

also occupies the tops of some of the neighboring hillocks, which have been separated from one another by erosion subsequent to the last voleanic outbursts.

In the canyon of the Carson River, a few miles southwest of Dayton, the stream has ent down 400 to 800 feet, exposing lavas like those in Eldorado Canyon. The uppermost of these flows is a white, littlecompacted rhyolite, while beneath it are large masses of a rock recognized in the field as lava, which on microseopic examination appears to be monzonite-porphyry. This is perhaps a coarser variation of andesite.

Between Dayton and Wellington the Pine Nut Range is mainly igneous. The central ridge has a massive aspect in general, and is probably made up of the granitic rocks.

Where the road between Genoa and Wellington crosses the range, hornblende-biotite-andesites occur on the western slopes. As in Eldorado Canyon, the whole system of gulches has been cut in this lava. 
Near the summit of the low pass on this road were found cliffs of a dense, massive, volcanie breccia with horizontal bedding and containing pebbles of rhyolite only. Some distance farther up, apparently belonging to the same series as the breccia, was found an ancient, apparently water-laid tuff, which microscopie examination shows to be rhyolitic, with above it a bed of coarse voleanie grit, and still higher a bed of voleanie eonglomerate with large well-rounded pebbles of biotite-rhyolite and a matrix derived from the same rock. A short distance farther the roeks from which these detritals are derived were found in place in a hill to the north of the valley and to the east of the pass. 'This rock shows many and great variations, passing from a fine-grained aphanitie rhyolite to eoarse granite and alaskite, and these variations are arranged in thin bands.

These are essentially quartz-feldspar rocks, generally eontaining biotite. They comprise biotite-rhyolite, fine-grained granite-porphyry, medium-grained biotite-granite, coarse-grained alaskite and graniteaplite, and one specimen was a fine-grained quartz-monzonite-porphyry. These different varieties present, texturally and strueturally, almost perfect transitions from one to another, ranging from eoarse granites through the granite-aplites and porphyries to the rhyolite, and the development of the different structures from the fine-grained rhyolite is very clear and instructive. Only one band was found which did not belong to the general granitie series. This was a band of darkgreen slaty rock, which, when examined, proved to be probably hornblende-andesite; yet this rock does not appear to be intrusive, but to form a band or streak probably contemporaneous with the more siliceons roeks.

West of this old granite-rhyolite area, andesite eomes in above it again, of the same kind as before. Where it has been deeply eroded a coarser. textural type is exposed; for example, the hornblendeandesite with eryptocrystalline groundmass, whieh represents the rocks near the surface, gives way in some deeper euts to hornblendeandesite with granular groundmass, which is transitional to hornblende-diorite-porphyry.

\section{SEDIMENTARY ROCKS.}

TRIASSIC LIMESTONE.

Southeast of Dayton, limestone, in extremely seanty onterops, just visible beneath the overlying volcanics, was found on both sides of the range. On the eastern side the limestone is massive, dark-blue and sometimes siliceous. Its laminie are vertieal, althongh they may result more from shearing than from stratification. It is eut by andesite dikes. On the western side of the mountain, in EIdorado Canyon, the limestone is also blue and siliceons, ehanging to shaly and carbonaceons. It is erushed and seamed, but appears nearly 
horizontal. The shaly limestone contains nearly obliterated fossils, upon which Mr. T. W. Stanton comments as follows:

The collection *** yielded only fragments and impressions of a Pecten and a specimen that appears to be part of an Ammonite. These are Mesozoic and probably Triassic.

This locality is probably the same as that mentioned by Whitney" as having yielded the Triassic fossil Goniatites lovidorsatus Hauer.

This Triassic limestone is probably to be correlated with King's Triassic Star Peak limestone. ${ }^{b}$

In the Pine Nut Range the limestone is probably older than the granitic rock which forms the main range, between its two outcrops,
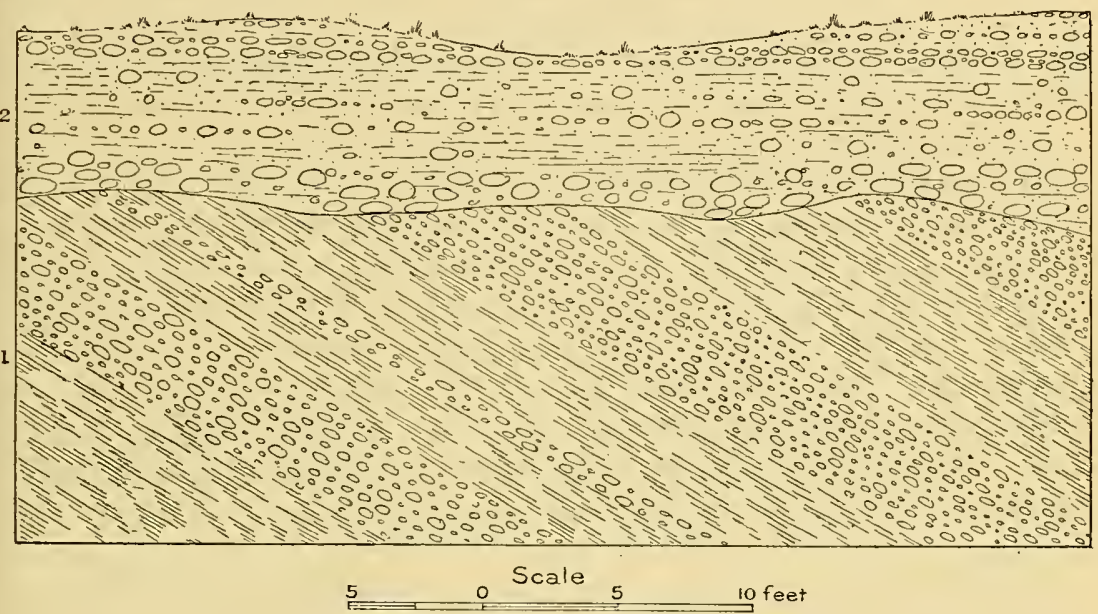

Fig. 9.-Sketch section of wall of arroyo in bottom of Eldorado Canyon, Pine Nut Range.

1. Gravels (pebbles mostly andesite) with coarse clays (Pliocene-Shoshone lake sediments?). Tilting probably local.

2. Stratified bowlders and earth (Pleistocene).

for it contains no granitic detritus. The granite must have burst up through the limestone in a great belt.

PLIOCENE DEPOSITS.

On the west flanks of the mountains above Dayton, as already described, there are found some hardened, well-stratified gravels and clays, derived from the andesites, and overlain, often unconformably, by stream gravels (fig. 9). 'They have the appearance of having been deposited in moving water, but this aspect may well hare resulted from current action in a stable water-body. On the face of the range just east of Dayton there is a rough inclined plane running up to a height of 6,000 feet and terminating in obscure benches. Abore this termination the mountain rises sharply and steeply, as may be seen on the Carson topographic sheet published by the U. S. Geological 
Survey. The approximately horizontal upper limit of the plane suggests lake aetion, and the older gravels and clays in Eldorado Canyon strengthen the idea. At Dayton Professor Russell ${ }^{a}$ has plaeed the limit of one of the bays of Lake Lahontan at an elevation of 4,375 feet. The above-mentioned bench is, therefore, 1,625 feet above the uppermost limit of the Pleistoeene lake. Sonthward from Dayton the leveled plane was not observed, and it is probable that some of the lavas whieh here form the mountain flanks were laid down in the lake period and so corered the plane or prevented its erosion.

In the platean valley between Dayton and Carson there ocenr stratified clays and eoarse gravels, at heights of several hundred feet above the Pleistoeene Lake Lahontan. Near Carson there occurs a hardened sandstone or granitic arkose, which is well exposed at the State prison. The rock here eontains plant remains and occasional fresh-water shells. One of these shells submitted to Dr. WV. II. Dall was determined as Anodonta, belonging to a reeent speeies found living in California. Dr. Dall adds that the species may be older than the Pleistocene, since the genns goes back as far as the Eocene; but that sinee the genus is so easily affected by environment, the same species is rarely found in more than two horizons. Exeavations in this rock at the State prison have brought to light layers eovered with footprints of the extinet elephant and other mammals and birds. On the hill south from the prison there is benching up to a height of 4,850 feet. The same sandstone as shown at the State prison, but somewhat looser and more friable, oceur's west of Carson at the foot of the Sierras. ${ }^{b}$

South of this point, along the face of the range, there is a belt of low hills often eovered up by the Pleistoeene detritus, bnt consisting, when exposer, of stratified sands and gravels. On the western face of the Pine Nut Range, southward from Carson, there is generally visible a distinct line in the topography at about 6,000 feet, below which the slopes are gentler and above which the mountains are steeper and more rugged. Along the road whieh erosses the range from Genoa to Wellington stratified sands and gravels, earrying wellrounded pebbles, oecur in hills covering the gently inclined plain at

\footnotetext{
a Mon. U. S. Geol. Survey, Vol. XI, Pl. XLVI.

$b$ After writing the above description the writer found that the locality had been already better described by Professor Le Conte and other's. He lets his own description stand only to slow how independent observations liave led to similar conclusions.

Professor Le Conte (On certain remarkable tracks, found in the rocks of Car'son quar'ry: Proc. Cal. Acad. Sci., Aug. 2\%, 1882) describes a few fresh-water fossil shells of species still living in the vicinity. Among the vertebrate remains are fragments of tusks and molars of an elephant, and molars and fragments of jaws containing molars of two species of horse.

Concerning the age of the beds he concludes that if not Quaternary, they can not be earlier than Upper Pliocene passing into Quateruary. He also suggests that they are possibly deposits of King's Lake Shoshone, and not Lake Lahontan.

Professor Le Conte observed that the level at this locality is 240 feet higher than the uppermost shore line of the Pleistocene Lake Lahontan, which, moreover, did not extend so far' west as Carson.
} 
the base of the steeper mountains. These hills are considerably eroded. Near the mountains the pebbles are larger, and in crossing the range the stratified deposit stops at 6,000 feet precisely, above which the rocks are bare. Below the uppermost gravels are benches in the detritus and in the lava on which the detritus lies. These benches, as well as the eanyou of the Carson River at this point, seem to have been ent during the recession of the lake to which the gravels owe their origin, and whose uppermost shore line was at the 6,000-foot cut. On the western side of the range there is also a pronounced scarp above the 6,000-foot contour, and beneath this stratified gravels constitute the fomdation of the valley between the Pine Nut Range and the northern end of the Sweetwater Range.

The uniform and general distribution of these water-deposited gravels and sands, up to about 6,000 feet, and the horizontal groin which occurs on the mountains about the same height, suggest that the deposits were laid down in a Iake, which had its surface at its time of maximum extension at the altitude above mentioned. That the lake was older than the Pleistocene is shown by the fact that the Pleistocene Lake Lahontan reached an altitude of only 4,375 feet. The induration of the sediments of this higher lake, as seen in the sandstone of Carson, also points to a greater age; and the great amount of subsequent erosion, illustrated in the carving of the canyon of Carson River, indicates that the maximum extent of the lake was at a period which was removed from the period of maximum extension of Lake Lahontan by a time interval much longer than from the latter period to the present day. On the whole the deposits of this older lake will be considered late Pliocene.

\section{SWEETWATER RANGE.}

The Sweetwater Range may be considered as the southern prolongation of the Pine Nut Range, from which it is separated by the valley of the West Walker River, at Wellington. It is also a spur of the Sierras, into which it passes at its southern end.

\section{TOPOGRAPHY.}

The Sweetwater Mountains are high and rugged for the most part, with bold peaks and cliffs. The eastern face of the northern part of the range, from Wellington southward to Desert Creek, is steep and straight. Southwest of Wellington the West Walker River has cut a deep canyon along the face of the range, below the level of the broad desert valley separating it from the Pine Nut Range. On the road from Wellington to Sweetwater, the Sweetwater Range is separated from the Smith Valley Range on the east by the deeply cut Dalzell Canyon. 
IGNEOUS ROCKS.

POST-PLIOCENE BASALTIC LAVA.

The gravels and sands which occur in the valley separating the northern end of the Sweetwater Range from the Pine Nut Range belong to the ancient sediments which have already been provisionally classified as Pliocene. Along the canyon of the West Walker River, a short distance southwest of IVellington, there occur in places sheets of colummar basaltic lava, overlying the gravels. This is probably nearly contemporaneous with the basalt in Eldorado Canyon, of the Pine Nut Range.

\section{LATE RHYOLITIC LAVA.}

The highest portion of the Sweetwater Range, just west of the postoffice at Sweetwater, is distinguished by the brilliant light-gray, yellow, and red which its rocks assume on weathering. 'These rocks all seem to be gray, essentially fine-grained, thin-bedded surface volcanics. They were not examined in place, but a typical specimen selected from the blocks derived from this mountain proves on chemical analysis to be rery siliceous rhyolite ${ }^{a}$ or tordrillite. ${ }^{b}$

\section{LATE ANDESITE AND LATITE.}

In the same canyon as above mentioned (near WVellington), there occurs, beneath the rolled gravels, stratified ash, dipping northwest away from the mountains. Below this ash occurs lava, through which also the river has cut. There are two distinct flows, the lower of which has a perfect columnar jointing, while the upper one is often brecciated and rests upon the apparently eroded surface of the lower. The rock of the lower flow, microscopically examined, proves to be bronzite-andesite, that of the rpper one hormblende-biotite-latite. The uppermost of these flows has been deeply weathered, and has been displaced by a fault, which is subsequent to the weathering.

The andesite is of the same composition as the ancient andesite which forms the greater part of the range, but its association with breccias and gravels stamp it as being younger than the main mass and intermediate between it and the latite.

In Dalzell Canyon are coarse volcanic breccias, with thin interbanded flows, all dipping at moderate angles irregularly. A specimen from a hard bowlder in the breccia is hornblende-bronzite-andesite. These breccias and thin flows are probably younger than the massive andesite of the main range. They are very likely of about the same

a Dr. H. W. Fairbanks (Am. Geol., Vol. XVII, p. 152) mentions a rock in Ferris Canyon, in the Sweetwater Range, which is probably the same as that above described.

b Tordrillite is proposed as the fine-grained equivalent of alaskite, and differs from rhyolite in being in general more siliceous and containing no essential ferromagnesian minerals. See J. E. Spurr, Classification of igneous rocks according to composition: Am. Geol., Vol. XXV, 1900, p.210. 
age as the breceias in Eldorado Canyon, in the Pine Nut Range, which they resemble exactly.

Just south of the post-office at Sweetwater similar hormblendebronzite-andesite comes in, overlying the ancient rhyolite series. This is of the same general age as the breceias in Datzell Canyon.

EARLIER ANDESITES.

Most of the Sweetwater Range to the north of the high gray rhyolitic peaks above described is of red, deeply eroded lava. Near Wellington, and at the northern end of Desert Creek, speeimens of this lava proved on examination to be hornblende-bronzite-andesite.

The main mass of hormblende-pyroxene-andesite forming the bulk of the Sweetwater Range is older than the thin flows and breccias previously described. The later andesites are closely associated with gravels which were chiefly derived from the erosion of the earlier andesite.

\section{EARLIER RHYOLITE.}

Just below Sweetwater there outcrops a gray lava which has somewhat the aspect of a pyroclastic breccia. A specimen proves to be rhyolite, with a microcrystalline granular groundmass, and containing small fragments of a gray basic lava free from quartz. This rock is of exactly the same type as one examined from the banded graniterhyolite series in the Pine Nut Range, on the road between Genoa and Wellington. At Sweetwater, also, this lava has an ancient appearance. It has a pronounced jointing, or sheeting, in two direetions, at right angles to one another, one striking N. $70^{\circ} \mathrm{E}$. and dipping $70^{\circ} \mathrm{SE}$, and the other dipping $70^{\circ} \mathrm{NE}$. This rhyolite is overlain by hornblende-bronzite-andesite.

GRANITIC ROCKS.

Along the eastern side of the northern portion of the Sweetwater Range, south of Wellington, there is, back of the main scarp, a seeond scarp composed of gray and massive rocks. In the bottom of the valley east of here are rolled pebbles and bowlders of granular and porphyritic granitic rocks. As one goes southward from here he may trace the scarp of gray rocks into Desert Creek Canyon, which seems to be eut in similar rocks, and the uppermost portion of Desert Creek Peak is seen to be of the same material. Just east of Desert Creek Peak, at Wileys, granite actually outcrops, beneath hornblendebronzite-andesite. The granite is in part coarse and porphyritic, containing large feldspars, which have inclusions of dark minerals, and is of the same variety as noted at Belmont, Ellsworth, and on the eastern face of the Pine Nut Range, southeast from Dayton. There is also some nonporphyritic granite, and some containing few dark minerals, and so verging on alaskite. 
The granitic rocks have been decomposed to a depth of many feet, so that no specimens could be collected. This decomposition occurred before the eruption of the andesite, for this lava is fresh where it overlies the rotten granite. The period sufficient for this decomposition is considerable, and it must have been preceded by a long period of erosion, which exposed the granite.

In the valley drift above noted there was found, besides granite, specimens of porphyritic siliceous rock, transitional between granite and rhyolite. It is possible that the granite and the rhyolite at Sweetwater may be of nearly the same age and may be correlated with the ancient granite-rhyolite series of the Pine Nut Range.

\section{SEDIMENTARY ROCKS.}

PLIOCENE DEPOSITS.

The valley which separates the northern end of the Sweetwater Range from the adjacent Pine Nut Range is covered with bedded gravels, throngh which West Walker River has cut a Pleistocene canyon. Besides the rolled gravels, which are largely derived from the andesite of the monntains, there are some beds of stratified ash. Across the range from here, the foot of the main scarp north of Desert Creek ends in a sloping plain at an elevation of 6,000 feet; and in the valley below this the deposits consist of rolled gravels similar to those exposed in Walker River Canyon.

South of Dalzell Canyon and east of the highest peaks of the Sweetwater Range is a broad, gently sloping valley, several miles across, reaching back to the Sweetwater Momntains, which rise sharply from it at an altitude of about 7,000 feet. The surface of this valley is smooth, and slight cuts in it show a stratified deposit of arkose and angiular fragments of lava. ${ }^{a}$

All these deposits are provisionally referred to the Pliocene.

\section{RÉSUMÉ.}

Probably the oldest rocks of the range are a series of granites and ancient rhyolites, which were perhaps contemporaneous. They have been jointed by dynamic action, and are deeply decomposed.

The succeeding geologic formation was a hornblende-pyroxeneandesite, which was poured out in great masses over the underlying siliceous mountain core. Subsequent to this, the andesite was deeply eroded, and probably a lake was formed. The material-derived from the erosion of the andesite and of the underlying siliceous rock was spread ont in the valleys as gravels.

During this erosion period thin sheets of andesite similar to the main mass were poured out. 
Later than this, but also probably while the lakn still existed, a more siliceous lava, which has been classified as hornblemde-latite, was poured out, in comparatively thin sheets. The rhyolites or tordrillites of the highest portion of the range were probably poured ont at approximately the same period, so far as we can judge from the amount of erosion.

The shrinking of the lake exposed to erosion those lavas which had been poured out in it, and the present stream canyons were cut in the lake sediments and the lavas. At the same time thin sheets of basaltic lava were locally erupted.

At the southern end of the Sweetwater Range there appears to have ocenrred, subsequent to the retreat of the lake, a local uplift, which has elevated the lake sediments and shore lines 1,000 feat above the same sediments in the regions north of here.

\section{VIRGINIA RANGE.}

The Virginia Range lies next east of the Sierras and north of Carson. It is ceparated on the son th from the Pine Nut Range by a narrow platean valley, in which Carson River has cut a Pleistocene canyon. The range rises abruptly from the plains at its base, and is high and rugged. The northern portion was examined by the geologists of the Fortieth Parallel Survey, and the geology of this part is represented on map 5 of the atlas accompanying that report. In the southern part of the range is the famous Comstock lode, and in this vicinity the geology has been studied in detail by King, Becker, and others.

\section{IGNEOUS ROCKS.}

With one or two unimportant exceptions, the Virginia Range is made up entirely of igneous rocks. These were thoroughly studied by Dr. Becker, ${ }^{a}$ and later were made the subject,of a critical study by Messrs. Hague and Iddings.

The igneous rocks consist partly of rocks with porphyritic structure and fine-grained or glassy groundmass, partly of those porphyritic rocks whose groundmass is comparatively coarse, and partly of typical granular rocks. At first these rocks of different structures but similar composition were described as distinet from one another and of different ages, but Hague and Iddings considered that the structures above enumerated oceur in the same ernptive bodies, the fincr-grained structures having oceurred at or near the surface, while the coarsely granular ones are typical of the core of the mountain, now made accessible by the deep mine workings. These conclusions were afterwards contested by Dr. Becker.

a Geology of the Comstock lode and the Washoe district: Mon. U. S. Geol. Survey Vol. III. Also California Acad. Sci., Bull. 6, 1886.

$b$ Oi the development of crystallization in the igneous rocks of Washoe, Nevada: Bull. U. S Geol. Surrey No. 1\%.

Bull. 208-03-9 
According to Dr. Becker, the succession of igneous rocks in this district is, beginning with the oldest:

Granite, metamorphies, granular diorites, porphyritic diorites, quartz-porphyry, porphyritic diabase, later diabase (black dike), earlier hornblende-andesite, angite-andesite, later hornblende-andesite, basalt.

The succession, according to Hague and Iddings, is as follows:

1. Pyroxene-hornblende-andesite (in its coarser inner portions becoming pyroxene-hornblende-diorite-porphyry and pyroxene-hornblende-diorite).

Period of volcanic rest and denudation.

2. Hornblende-mica-andesite.

3. Dacite.

4. Rhyolite.

5. Pyroxene-andesite.

6. Basalt.

All these igneous rocks are considered by Hagne and Iddings as Tertiary, but they have been divided into Tertiary and pre-Tertiary by Becker and others.

\section{SEDIMENTARY ROCKS.}

ANCIENT LIMESTONES.

Mr. Becker ${ }^{a}$ described near Virginia a small area of distinctly stratified rocks, consisting of limestones and greatly metamorphosed micaceous schists. No fossils were found. They are perhaps similar to the Triassic limestones found a few miles sonth of here, in the Pine Nut Range near Dayton. (See p. 207.) 


\section{H A P T E R I I I.}

\section{RANGES OF SOUTHERN NEVADA.}

\section{VIRGIN RANGE.}

The Virgin Range is just within the eastern limit of the folded strata of the Basin ranges and west of the nearly horizontal rocks of the Colorado Plateau. ${ }^{a}$ According to Dutton, ${ }^{b}$ the exact bonndary between these two provinces is the Grand Wash, the valley which lies immediately east of the Virgin Range. In this valley is a heary fault with downthrow to the west. Dutton says:

This fanlt is the boundary of the Grand Canyon district and of the Platean country itself. The region beyond is a Sierra country, with the same characteristics as the Great Basin of Nevada and western Utah.

\section{SEDIMENTARY ROCKS.}

PRE-TERTIARY.

According to Marvine ${ }^{c}$ the rocks exposed in the main body of the Virgin Range present the same general sequence as is shown in that portion of the range eut by the Colorado River. The fundamental rocks are Archean gueisses, schists, granites, etc., orerlain by Cambrian rocks, which in turn are capped by a great thickness of Carboniferous rocks of the Red Wall and Aubrey groups. At the extreme northern end of the range, east of Beaver Dam Wash, an area of red sandstones, supposed to be Triassic, although no fossils were found, has been mapped by the geologists of the Wheeler Survey, ${ }^{d}$ but is not included in the map accompanying the present report.

PLIOCENE.

Besides the Arehean and Paleozoic rocks, Marvine ${ }^{e}$ describes in the Grand Wash, which lies just east of the Virgin Range, a series of ompact conglomerates, which constitute a very large amount of the valley filling and which have often been eroded into a rolling or hilly surface with deep valleys. This conglomerate contains some beds of ava, is horizontally bedded, and abuts unconformably against the olded Carboniferous rocks of the mountains. Southward from the 
Colorado, in another valley, the same gravels or conglomerates are met with, overlain by calcareous tufas several hundred feet in thickness.

On traveling along the west side of the Mormon Range toward the pass between it and the Muddy Range, the writer noted that the greater portion of the valley of the Virgin River lying east of the Virgin Range was covered with slightly eroded Tertiary strata, probably identical with the horizontal red, gray, and brown sandstones and conglomerates observed in the lower portion of the Meadow Valley Wash. ${ }^{a}$ 'The conglomerates in the Grand Wash, on the other side of the Virgin Range, described by Marvine, probably belong to the same series. As observed by the writer in the Meadow Valley Wash, they have the appearance of having been deposited in a lake, although it is possible that they represent the valley accumulation of the Colorado River, at a period when the streams of this system ocenpied wide valleys, in which they worked laterally and deposited the material which they derived from the crosion of the mountains, the carrying power of the streams at that time not being equal to the amount of load received. 'These sediments occupy the older valleys which were eroded in the Paleozoic limestones and in the earlier Tertiary sediments and lavas, but they were laid down before the down cutting of the latest sharp gorges, for they stand as the walls of these. They lie against the Carboniferous limestones, and, as described by Marvine, against the Archean granites along the Grand Wash.

According to Dutton ${ }^{b}$ the greater part of the general denudation of the Colorado drainage region was probably accomplished in Miocene time, whereas the cutting of the Grand Canyon probably began in the early part of the Pliocene. The conglomerates and sandstones under consideration were evidently deposited just before the period of rapid canyon cutting, and this, in conjunction with the evidence afforded by the underlying unconformable Tertiary rocks in Meadow Valley Canyon, may be sufficient grounds for specifying their age provisionally as Pliocene.

\section{IGNEOUS ROCKS.}

Marvine ${ }^{c}$ describes large masses of black basaltic lavas resting upon the eastern base of the Virgin Range. Where the Colorado River euts the range, at Virgin Canyon, Mr. Gilbert ${ }^{d}$ describes lavas overlying the gneissic Archean rocks.

\section{STRUCTURE.}

As seen from the west, the limestones of the central portion of the Virgin Range present dips of $15^{\circ}$ to $30^{\circ}$, and strikes indicating some- 
what irregular folding. Marvine a records that the main fold of the range is anticlinal and that a fanlt exists along the cast face. This is probably the fault mentioned by Dutton, ${ }^{b}$ which has a downthrow to the west of between 6,000 and 7,000 feet.

Toward the sonth the folding appears to die ont so as to be nearly horizontal in the Colorado Canyon.

\section{COLORADO CANYON.}

That part of the canyon of the Colorado which is represented in the southeastern cormer of the map accompanying this report lies near the boundary between the Colorado Platean on the east and the region of the Desert or Basin ranges on the west. The Colorado Plateau is characterized by nearly horizontal rocks forming mesas or bcnched platforms, while the region to the west has many different ranges of high rugged momtains composed of folded strata.

The rocks exposed in this portion of the canyon are Carboniferous and lower. At the month of the Grand Canyon Mr. Gilbert made a section showing ${ }^{c}$ over 5,600 feet of rocks, being all horizontal strata except the extreme base, where the granites and gneisses of the Archean appear. Above the Archean rocks are 755 feet of shales, sandstones, and some limestone belonging to the Upper Cambrian of the Tonto group. Above the Cambrian comes in, in apparent conformity, heavy limestones with some sandstones, having a thickness of 2,675 feet. This is the Red Wall limestone of the Carboniferous. Above the Red Wall comes in the Aubrey group of the Upper Carboniferons, consisting of 1,300 feet of shales, sandstones, and cherty limestones.

Later, Mr. Walcott ${ }^{d}$ found in the Grand Canyon a slight thickness of Devonian, larely over 100 feet, between the Red Wall limestone and the Tonto rocks. Often the Devonian in this region is entirely absent, either through erosion or nondeposition. The rocks of this period are thin, purplislı, fine-grained sandstones, becoming calcareous and containing unmistakable fossils. Mr. Walcott observed an erosion break at the top of the 'Tonto strata, and another between the Carboniferous and the Devonian. No Silmian rocks are present.

At the base of the Tonto there is a great unconformity, beneath which occur sandstones, shales, limestones, and ancient lavas of the Chuar and Unkar divisions of the Grand Canyon group resting upon thin-bedded quartzites, which stand vertical and are broken through by intrusive masses of granite. Mr. Walcott considers that the strata

a U. S. Geog. Surv. W. One Hundredth Mer., Vol. III, pp 194, 196.

$b$ Second Ann. Rept. U.S. Geol. Survey, p. 126; also Mon. U. S. Geol. Surrey Vol. II, atlas Pl. II. eU S. Geog. Surv. W. One Hundredth Mer., Vol. III, fig. \$2, p. 196.

dAm. Jour. Sci., 3d series, Vol. XXVI, pp. 43\%, 484. 
between the Tonto and the thin-bedded quartzites belong to the Algonkian. The quartzites are AIgonkian or Archean. ${ }^{a}$

As one proceeds down the Colorado River from the Grand Canyon, he finds the upper strata snccessively disappearing, until, in Boulder Canyon and below, the Archean granites, gneisses, and schists come to the top of the canyon, except where covered up by 'Tertiary lavas.

\section{MORMON RANGE.}

The Mormon Range lies immediately east of Meadow Valley. It has an extent of about 40 miles, and a north-northeast trend. At its south end it is divided from the Muddy Range by the valley of Muddy Creek, while at its northeru end it merges into irregular volcanic mountains which cover a large area southeast of Pioche.

In topography the Mormon Range is not extraordinary, its peaks being fairly rugged and of moderate height. Running along the central part of the range, and parallel with its axis, is a continuous notch or incipient valley, about 2,000 or 3,000 feet deep, which nevertheless has not yet been deeply enough eroded to form part of the true valley system.

SEDIMENTARY ROCKS.

CARBONIFEROUS.

The great bulk of the Mormon Range is almost free from igneous rocks and is made up of a dark-blue, sometimes crystalline limestone, with some reddish shaly beds. In Meadow Valley Canyon, on the northeast flanks of the range, a spur of this limestone contained the following fossils which were determined by Dr. Girty, of the United States Geological Survey, to be Upper Carboniferous:

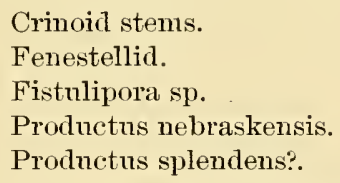

Productus punctatus? Spirifer cameratus. Spiriferina gonionotus. Seminula mira.

This is probably the Red Wall limestone group of Gilbert's Grand Canyon section. ${ }^{b}$

The same limestone series is exposed in Hackberry Cañyon, a few miles south of here, and it probably constitutes the bulk of the range.

In drift from the sonthern part of the range, found in the sonthern part of Meadow Valley, were pebbles containing the following Upper Carboniferous fossils:

Syringopora multattennata.

Fusulina cylindrica.

Archæocidaris sp.
Chætetes milleporacens?

Productus semireticulatus.

Below Hackberry Canyon, in Meadow Valley Canyon, there is 
found, overying the more massive dark-blue limestone, a series of pink sandstones, cherty limestones, and shales of considerable thickness. At Kane Spring, thin-bedded, siliceous, eherty limestones, with yellow, limy shales, belonging to this upper series, eontain poorly preserved fossils, referred by Dr. Girty to the Upper Carboniferous. This is undoubtedly the Anbrey group of the Grand Canyon section. ${ }^{a}$

The Aubrey Carboniferous lies conformably on the Red Wall Carboniferous, and both lie conformably beneath the lower rhyolite series of Meadow Talley Canyon. ${ }^{b}$ They are separated from the later Tertiary formations, especially the probable Pliocene sandstones and conglomerates, by a marked inconformity.

PLIOCENE.

The Pliocene which lies against the flanks of the Mormon Range, in Meadow Valley Canyon, will be considered in the special description of the canyon. The rocks consist of horizontal or slightly undulating red, gray, and brown sandstones and conglomerates, the latter often honeycombed, rising to a height of about 5,500 feet above sea level, and lying against the folled limestones of the mountains. The conglomerates contain pebbles of the fossiliferous Carboniferous limestones, as well as of the older 'Tertiary formations.

As seen from the gap between the Mormon Range and the Muddy Rauge, large areas on the eastern side of the Mormon Range are probably oceupied by Pliocene strata similar to those found on the western, these beds covering much of the broad valley between the Mormon Range and the Virgin Range.

\section{IGNEOUS ROCKS.}

Despite the fact that much rolcanic material was found closely adjacent to the Mormon Range on the north and west, there seems to be little in the range itself. The volcanic rocks on its western flanks will be treated in the description of Meadow Talley Canyon.

\section{STRUCTURE.}

The Mormon Range, as viewed from the west, appears to consist chiefly of an anticlinal fold, whose trend diverges somewhat from that of the range, since it runs in a direction west of north, while that of the range rums east of north. On the western slope of the range there was observed a parallel synclinal fold of comparatively small extent, flanked by another slight anticline still farther west. These two folds are probably local. They are succeeded on the west by a syncline which occupies the broad platean valley in which Meadow Valley Canyon lies. (See fig. 10.)

As seen from the north the main anticline is comparatively gentle, 


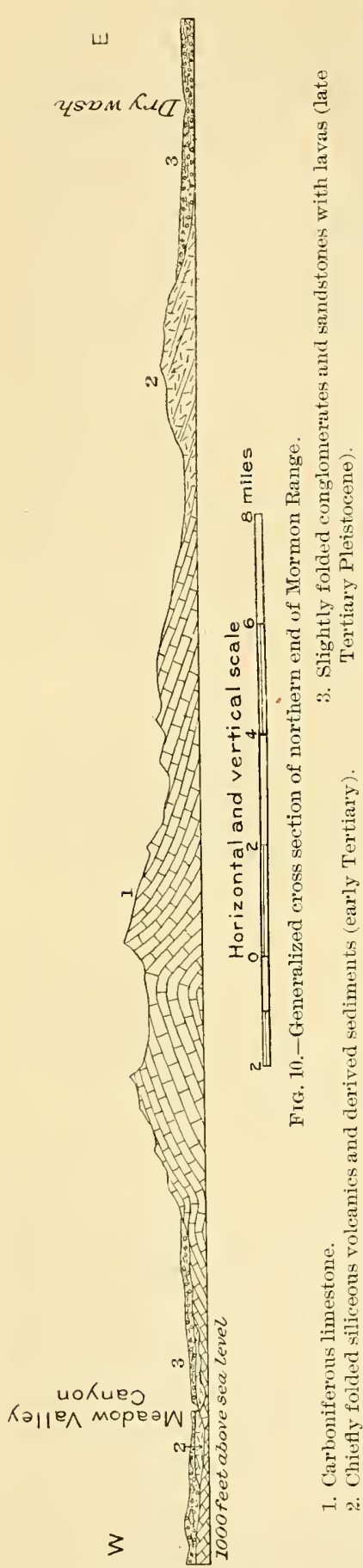

the dips on both sides appearing to be about $15^{\circ}$. Farther south, however, these dips gradually increase, and in one conspienous peak in the southcentral part of the range the strata are sharply compressed, forming a type of structure quite mnusual in the desert ranges, but still present, especially in certain ranges lying elosely east of the Sierra Nevada. ${ }^{\prime}$

It has already been noted that the limestone which forms the Mormon Range seems to be conformably overlain, on the flanks of the range, by a Tertiary rhyolite and rhyolite tuff series. ${ }^{b}$ That there was an erosion interval between the Carboniferous and the rhyolite period is shown by the irregularity of the eontact, as, for example, at the mouth of Hackberry Canyon, where the rhyolite is found on one side of the canyon and not on the other. Nevertheless, most of the folding which brought about the formation of the range certainly did not begin until after the rhyolite period. The limestones must also have taken part in later movements, evidenced by folding in the postrhyolitic Tertiary rocks to be described in considering Meadow Valley Canyon, which are separated from the rhyolites by an uneonformity. Thus the total amount of folding in the range is the combined result of all the Tertiary movements, which, from phenomena observed in Meadow Valley Canyon, seem to be still in progress.

\section{MUDDY RANGE.}

The Muddy Range is a southward contimuation of the Mormon Range, being separated from it only by the gap of Muddy Creek. It extends south to the Coloraclo River, where it is separated from the Colorado Range by Boulder Canyon. 


\section{SEDIMENTART ROCKS.}

The Carboniferons strata of the Molmon Range appear in the field to be continuous into the northern end of the Nuddy Range. The southern portion of the range, however, is represented on the Wheeler survey geologic map as composed of 'Triassic rocks."

At the extreme southern end of the range, in Bonlder Canyon, only the Arehean igneous rocks and gneisses are exposed, as described by Mr. Gilbert. ${ }^{b}$ These are overlain by Tertiary lavas.

The following observations were made by Mr. R. B. Rowe ${ }^{c}$ :

CARBONIFEROUS.

Abont 4 miles west of Logan, on Muddy Creek, there oceurs probably Carboniferous limestone, overlying Mesozoic sandstones and conglonerates. Between Logan and Weiser's ranch, above the Narrows, Paleozoic limestone is again shown, being bronght against the Mesozoie by a beary fault. The Mesozoic also seems to lie conformably upon the limestone on one side of the fanlt plane.

Fossils collected 3 miles west of Logan post-office by Mr. Rowe were determined by Dr. Girty as rather doubtfully Permian.

MESOZOIC.

At the first locality above-mentioned, 4 miles west of Logan postoffice, there are bright-red hills of massive cross-bedded sandstone showing no bedding planes. West of these hills are softer red-elay beds, bluish shale beds, gray eonglomerates, and thin limestone beds. Some of the limestone beds contain fossils, regarded by Mr. Rowe as Jurassic. Mr. Rowe's collection was examined by Mr. T. W. Stanton, who referred it possibly to the same horizon as fossils from similar beds in the south part of the Spring Mountain Range. He believes the horizon is not younger than the Triassic and may be as old as the Permian, but as the forms are all new no definite statement can be made.

One of the eonglomeratic strata contains considerable petrified wood. From some of the darker shales of the Mesozoic some narrow seams of coal, from one-half to one inch in thickness, have been reported.

At the second locality mentioned above, between Logan and Weiser's ranch, the Mesozoic again appears, lying conformably upon the limestone. ${ }^{d}$

\section{TERTIARY.}

On the north side of Muddy Creek, above the old California crossing, are the red, yellow, and bluish deposits of the Tertiary. On the

a U. S. Geog. Surv. W. One Hundredth Mer., Atlas Sheet No. 66.

$b$ Idem, Vol. III, p. 35.

'Taken fr'om his notebooks after Mr. Rowe's death, by the writer.

a This Mesozoic is mapped as Triassic to confor'm with the Wheeler survey mapping in the sonthern part of the range. It will be observed, however, that these beds may be, in partat least. the same as those mapped in the Spring Monntain range as Jurassic. 
sonth side, and undoubtedly conneeted with these, are elay deposits of considerable thickness and extent.

Between Logan and Weiser's ranch red and yollow elays and ancient talus deposits, now hardening into conglomerates, lie uneonformably upoil the Mesozoic.

\section{IGNEOUS ROCKS.}

In the northern part of the range the writera observed voleanie rocks overying the folded strata. On the Whecler maps patches of basalt are shown in a similar relation in the sonthern part of the range, and these extend, as described hy Mr. Gilbert, to Boulder Canyon.

\section{STRUCTURE.}

At the northern end of the range the stratified rocks seemed from a distance to dip eastward at high angles, but the actual structure was not made out. The folding probably deereases rapidly toward the south.

The following observations were made by Mr. R. B. Rowe:

About + miles west of Logan there is probably a fault between the Paleozoic and the Mesozoic. The Mesozoic dips quite sharply to

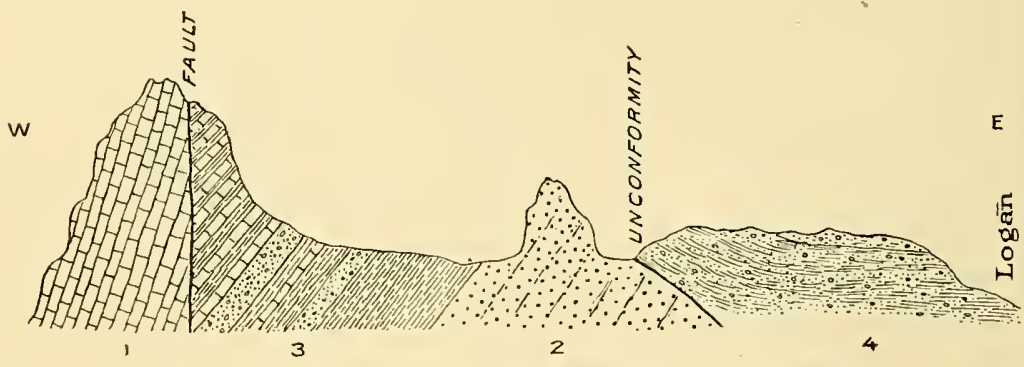

FIG. 11.-Cross section of Muddy Range, after R. B. Rowe.

1. Carboniferous limestone.

2. Massive red Mesozoic sandstone.
3. Mesozoic conglomerates, shales, and limestones. 4. Tertiary clays and consolidated talus deposits.

the west. Between Logan and Weiser's ranch the fault is beautifully shown, bringing the Mesozoic against the Paleozoic limestones. On the west side of the range the Mesozoic seems to line conformably upon the limestone. The dip of the limestone is almost perpendieular, while the Mesozoie lies against it, with a mueh lower dip, on the east side. (See fig. 11.)

\section{COLORADO RANGE.}

The Colorado Range is a southward continuation of the Muddy Range, and is separated from it by the Colorado River at Bonlder Canyon. Its geology is represented on the Wheeler geologie atlas 
(sheet No. 66) as consisting essentially of an Archean core overlain by lavas and flanked by Pleistocene detritus.

\section{ELDORADO RANGE.}

The Eldorado Range lies west of the Colorado Range, being separated from it by the Colorarlo River. As represented on the Wheeler atlas, its geology is about the same as that of the Colorado Range.

\section{MEADOW VALLEY CANYON.}

\section{TOPOGRAPHY.}

Meadow Valley Canyon is cut in the bottom of a broad north-south plateau valley, which separates the Meadow Valley Range on the west from the Mormon Range and other mountains on the east. Although the canyon is dry for long stretches, yet such water as may flow in it is carried to the Colorado, of whose drainage the canyon forms a part. That portion of the valley which is here described is about 90 miles in length, extending from the vicinity of Pioche southward to West Point or Moapa. The canyon begins a short distance sonth of Pioche, and grows continually deeper toward the south. The continuation of Meadow Valley northward from Pioche is called Duck Valley, which is a typical broad desert valley with no canyon. Opposite Pioche the appearance is already unlike that of the typical desert valley of the region. There comes in a central narrow strip of level wash, marking the channel of drainage, while on both sides there rises to the mountains a detrital slope, which, unlike that of most Nerada valleys, is cut up into low hills. To the south the central drainage channel becomes deeper, the slopes sharper, and the hills more cut up. To the north the reverse is the case, until the valley appears almost flat, like the typical Nevada valley.

From the vicinity of Pioche the incision of the drainage into the valley bottom becomes progressively more pronounced southward, until some few miles south of Panaca a box canyon begins, which soon attains a depth of 500 feet, and, within a few miles, 1,000 or 1,500 feet (Pl. VI, $A$ ). Some miles sonth of here, at Kernan's ranch, the canyon walls are estimated to be fully 2,000 feet high. Still farther south, and just northeast of the Mormon Range, the ralley widens out into a broad basin inclosed by mountains, for a few miles below which another shorter and somewhat lower canyon is entered. Below this is a broad, gently sloping plateau-ralley, in which the drainage channel, though generally sharp, is shallow. This platean grows wider toward the south, as also the valley which is cut in it. At the junction of the Muddy Creek and Meadow Creek drainage, near West Point or Moapa, the valley is 2 miles wide.

Meadow Valley Canyon offers exceptional adrantages for study. Most of the Nerada deserts are nearly level, and appear to be filled with Pleistocene accumulations, mostly subaerial. Observations in 
some of these flat valleys, however, show that Tertiary rocks crop ont in patches and that the Pleistocene cover is only a veneer. But, there being no drainage in these valleys, there is very rarely an opportunity to find sections cut by running waters, so as to study the real valley filling. In Meadow Creek Canyon we have such an opportunity. The slight incision in the valley opposite Pioche grows to a continnons canyon 1,000 or 2,000 feet deep, whose walls afford excellent sections of the Tertiary sediments and lavas which constitute the real valley filling between the ranges of Paleozoic strata on either side.

\section{PALEOZOIC ROCKS.}

On the west of the valley, the Highland and Meadow Valley ranges, and on the east the Mormon Range, are composed of Paleozoic strata, the Highland Range being chiefly Cambrian, the rest largely Carloniferous. Between these mountain ranges the valley probably existed before the deposition of any of the Tertiary rocks.

\section{RHYOLTTE.}

The oldest of the post-Paleozoic rocks noted in Meadow Valley Canyon was rhyolite. This was first enconntered at the upper end of the canyon, near Yokum's ranch, where it oceurs in rugged onterops. A specimen proved to be a siliceous biotite-rhyolite. This las been eroded, and against it has been laid down a horizontally stratified white rhyolite sandstone derived from it. The sandstone is hardened and forms eliffs and buttes. The rhyolite is thoronghly decomposed.

South of here, the basal rhyolite may be traced for some short distance in the canyon walls till it sinks below the bottom of the canyon and gives place to an enormons series of the overlying rhyolite sandstones, which contain interbedded thin sheets of rhyolite. There are in many places evidences that the basal rhyolite was eroded before the deposition of the overlying detrital series, for the latter often rests in the irregularities of the surface offered by the former. The rhyolites and the overlying derived sediments are folded throughout (dipping exceptionally as much as $30^{\circ}$, though usually deviating only slightly from the horizontal), and are often faulted, small faults being numerous, and those of 100 feet or more being not infrequent.

The basal massive rhyolite was again observed at IIackberry Canyon. In the section afforded here the lowest member is a white biotite-rhyolite, thoroughly decomposed. At the month of the canyon this rhyolite overlies the Carboniferons limestones conformably, the whole being folded together and unconformable to the overlying formations.

\section{RHYOLITE-SANDSTONE SERIES.}

At the upper end of Meadow Valley Canyon, at Yokum's, the consolidated rhyolite sandstone and conglomerate which overlies the massive rhyolite has already been described, and also its occurrence in the eanyon immediately to the south, where it succeeds the basal 


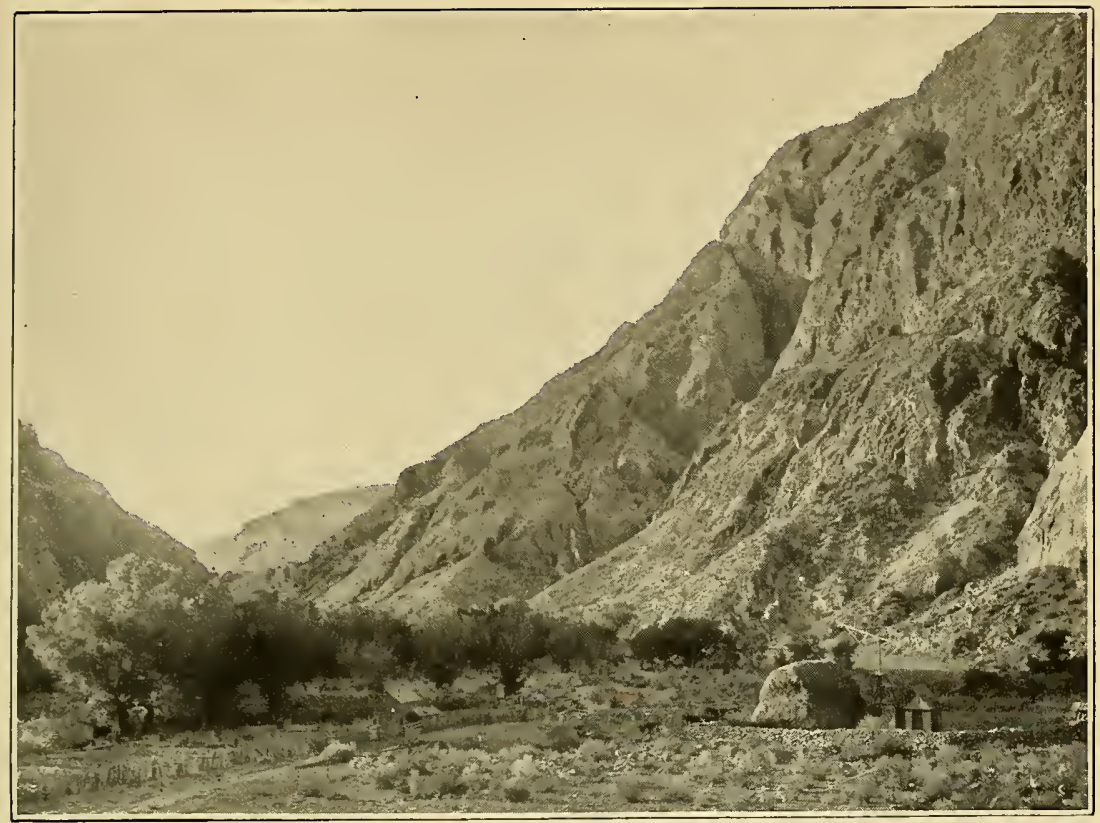

A. RHYOLITE WALLS OF MEADOW VALLEY CANYON AT CARSON'S RANCH.

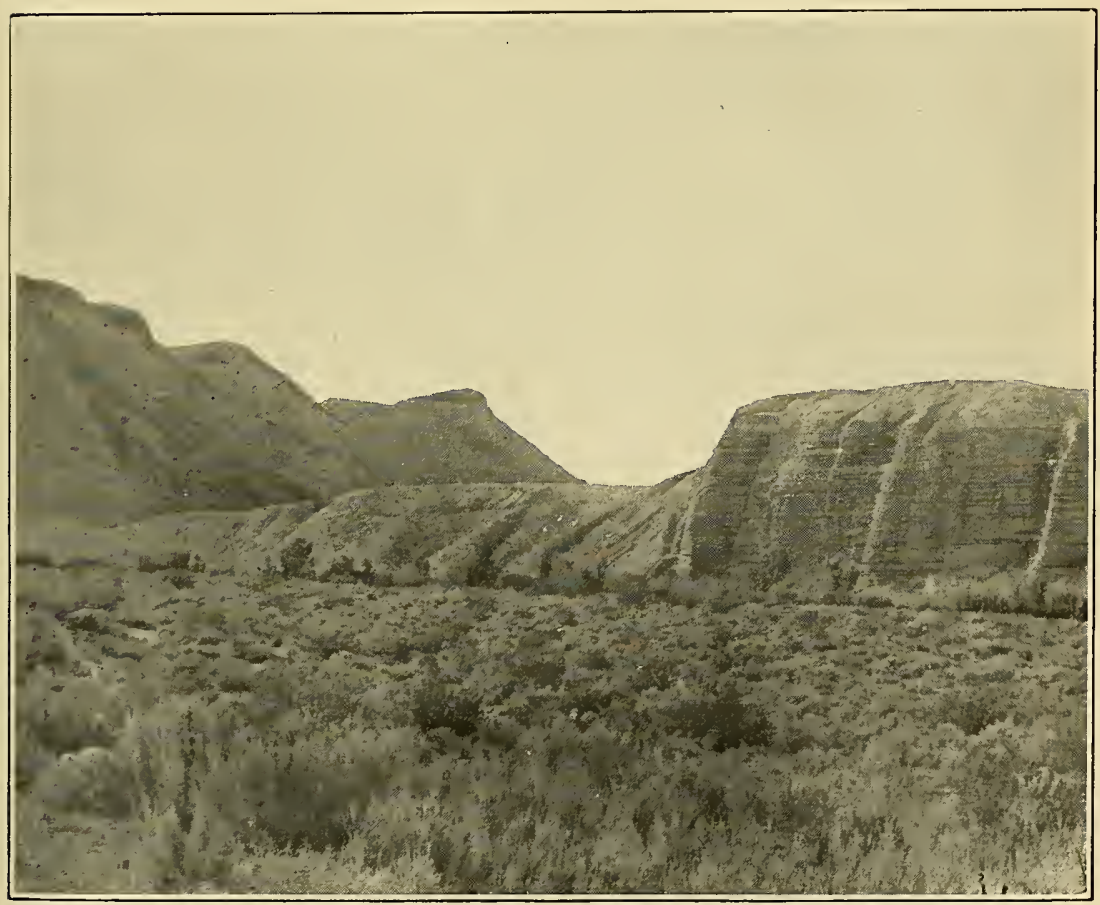

B. PLIOCENE CONGLOMERATE IN MEADOW VALLEY CANYON AT CANE SPRING. 

lava above an apparent erosion gap and is folded with it. The rhyolite-sandstone or tuff series is overlain unconformably by andesite, and is also eut by thin intrusive sheets of it.

There appear's also to have been considerable disturbance even during the deposition of the rhyolite-sandstone or tuff series, which is explessed by slight erosion gaps and irregularities between adjoining beds. During the deposition of this series, therefore, periodic effusion of thin sheets of lava and erosion seem to have gone on simultaneously. Some of the thin rhyolite sheets rest one upon another with diverging angles of banding, indicating to the observer

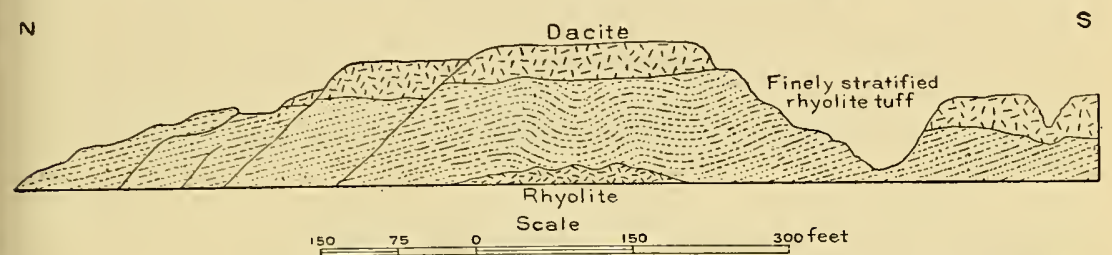

Fig. 12.-Sketch section of east wall of Meadow Valley Canyon just south of Carson's ranch, showing unconformity between rhyolite sands and overlying dacitic lavas.

at first sight an unconformity, since they have the appearance of being white stratified rock.

This series was estimated to be 4,000 feet thick, and is exposed southward to a point about 45 miles south of Pioche, where it gives place, on account of the general southerly dip of the folded beds, to later overlying sediments and lavas.

\section{ANDESITE-LATITE SERIES.}

There is found, overlying the rhyolite-sandstone or tuff series, at Yokum's ranch and in the canyon to the south, several hundred feet of basic lava, specimens which proved to be in general bronzite-biotite-andesite. A specimen collectel just above Yokum's, probably from the same general series, is biotite-hornblende-quartz-latite.

This anclesite-latite series rests unconformably upon the basal rhyolite or on the overlying rhyolite tuff (fig. 12) and also intrudes them in thin intercalated sills (fig. 13).

Flom the northern end of the canyon the andesites were not observed for many miles southward, but in Hackberry Canyon they were again found exposed in exceptionally good section. Here they overlie the basal rhyolite unconformably, and are themselves tilted so as to be unconformable below the overlying sands and gravels. At 
this point, as also at the northern end of Meadow Valley Canyon, the andesite contains considerable masses of volcanic breccia. It is considerably decomposed, though not so much as the underlying rhyolite, and specimens proved to be pyroxene-andesite.

\section{REDDISH DACITES AND RHYOLITES AND ASSOCIATED SEDIMENTS.}

In the southern half of the northern portion of Meadow Valley Canyon, above the open basin to the northeast of the Mormon Range, the andesites were not observed; but the rhyolite sandstone or tuff formation was found to be overlain by beds of brown and yellow tuff, containing a variable amount of red lava, in the form of sheets. The great variability in thickness of the lava sheets, and, therefore, of the interbedided sandstones, makes a study of the series very difficult, no two sides of the canyon ever matching; but, so far as examined, the

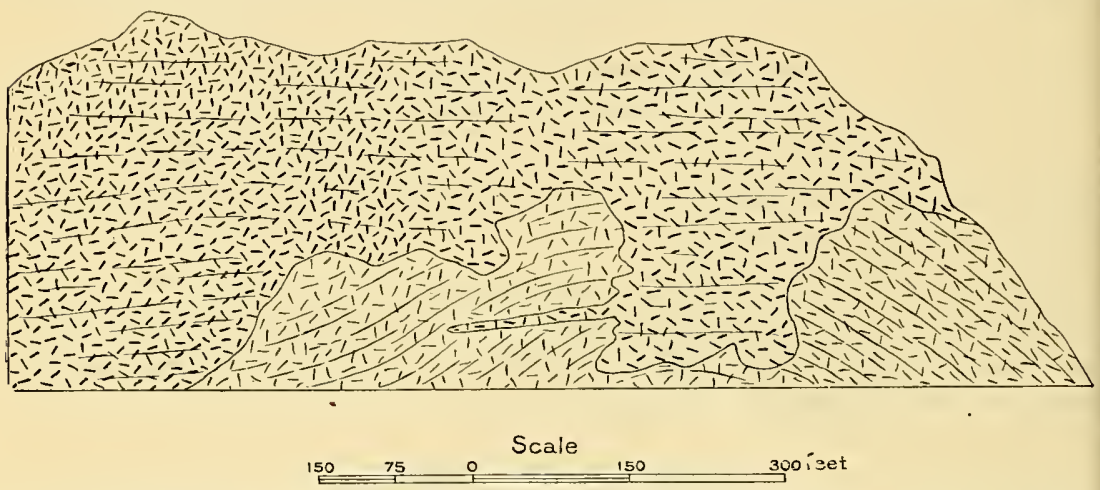

Fig. 14.-Sketch of east side of Meadow Valley Canyon near locality of figs, 12 and 13, showing contact of underlying rhyolite and overlying dacite, with no rhyolite sands between.

volcanic rocks found in this upper reddish series are in part biotitehornblende-dacite and in part pink rhyolite. It is not plain in the field whether this series of dacites and reddish rhyolites is older or younger than the andesites, for the two are not found together; but from the fact that the andesite is often found resting directly upon the basal rhyolite, it is inferred that it is probably older than the reddish dacite-rhyolite series. Between the series of red lavas and yellow-brown tuffs and the underlying series of white rhyolites and white tuff's there is a marked unconformity and erosion gap (fig. 14).

The dacites and reddish rhyolites not only form interbedded sheets contemporaneous with the yellow-brown tuffs, and furnish many of the pebbles in the associated gravels, but they have cut the same gravels and tuffs as intrusive sills, which are often of considerable thickness. Thus there are exposed sections in the canyon walls with the reddish roleanics at the base and the yellow-brown tuffs above, giving a false appearance, as if the sediments were younger than the lava. 
At one locality, near Kiernan's ranch, the brown tuffs and red lavas were seen to be overlain by a flow of pyroxene-olivine-basalt, whose lower boundary is irregular.

This whole series of red lavas and brown tuffs is broadly folded, although not so much as the rhyolitic series below. It has in general a sontherly dip, and where the canyon gives way below Kernan's ranch to the broad, level basin which lies northeast of the Mormon Range it is overlain unconformably by horizontal brown sandstone or tuff belonging to a later epoch.

\section{PLIOCENE BEDS.}

In the valley near Panaca the stream bottom has on both sides scarps 60 to 100 feet high, consisting of horizontally stratified silt and sand. These sediments are sometimes green and yellow and pass into rhyolitic arkose. The scarps are cut down in a level valley platean which has an elevation of about 5,000 feet; and from here on both sides a snceession of benches, more or less dissected, rise to the mountains. The highest well-marked bench was estimated at 6,000 feet.

In the northern portion of Meadow Valley Canyon, between Carson's and Kernan's ranches, the different series of interbedded lavas and tuffs above described, which are all more or less folded, give way for a few miles on the west side of the valley to a deposit of abont 2,000 feet of clean, brown rolcanic sandstone and tuff, beautifully stratified lorizontally, and extending to the top of the hills. The deposits are unfolded and unbroken, dipping sonth abont $2^{\circ}$, and having a maximum elevation of about 5,500 feet. In the npper part of this sandstone series there seems to be a few sheets of rhyolite and basalt, the basalt being the younger.

South of Kernan's ranch a series of brown, horizontally stratified, volcanic sandstones or tuffs comes in uncomformably above the slightly folded red lava and brown triff series, and fills the broad basin which lies northeast of the Mormon Range. Of these horizontal sandstones there is shown in the botion of the valley a thickness of about So0 or 900 fect, although neither the bottom nor the top was seen. Below the sandstones are barely exposed horizontal conglomerates, well indurated, and containing pebbles of various sizes up to 2 feet in diameter. This sandstone series continues south, and lies up against the slopes of the Mormon Range to a height of about 2,000 feet above the valley or about 5,500 fect above sea level. The lower portions of the sandstone are indurated, while the upper parts are softer. They are often honeycombed in consequence of unequal consolidation and erosion. In one locality they are overlain by a sheet of very recent tordrillite. These horizontal rocks acquire a slight wavy structure on approaching the spur of Paleozoic limestones which constitutes the southeru barrier of the basin. There are developed gentle folds with axes parallel to the spur, and dips averaging not more than $10^{\circ}$. 
Close up to the limestone buttress the folding is somewhat closer, and the strata have a wrinkled appearance.

At Hackberry Canyon the same series of horizontally stratified conglomerates and soft sandstones overlies the pyroxene-andesite, from

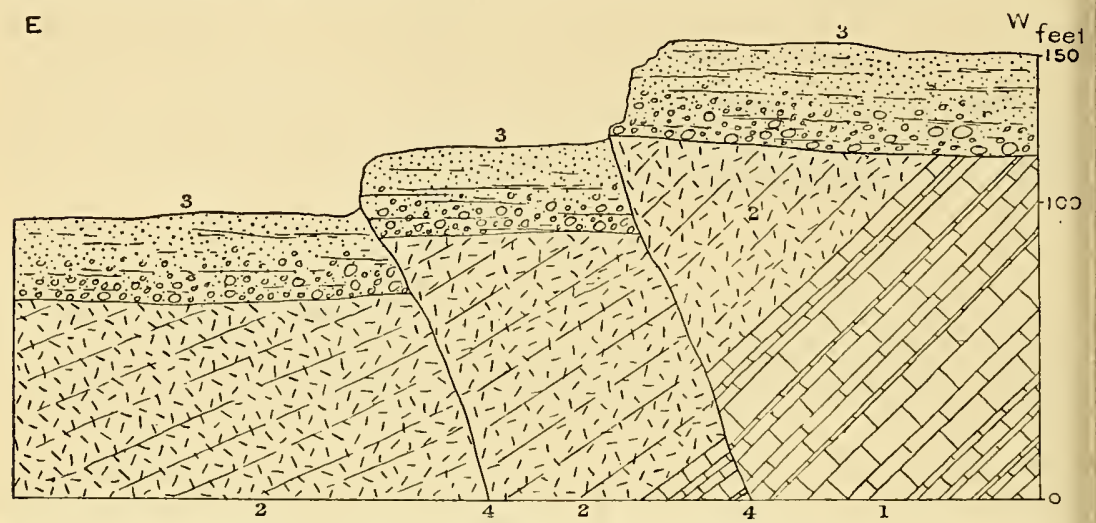

FIG. 15.-Sketch section of south wall of Hackber'ry Canyon near junction with Meadow Valley Canyon, showing Pleistocene faults and simple fault scarps.

1. Carboniferous limestone.

2. Rhyolite and derived sediments (probably early Tertiary).

3. Consolidated honeycombed conglomerate and sandstone (probably Pliocene).

4. Pleistocene faults.

which it is separated by an mnconformity and an erosion gap. At the month of 1Lackberry Canyon the same series is found, honeycombed and overlying unconformably the upturned basal rhyolites. Both the horizontal conglomerates and sandstones and the underlying rocks

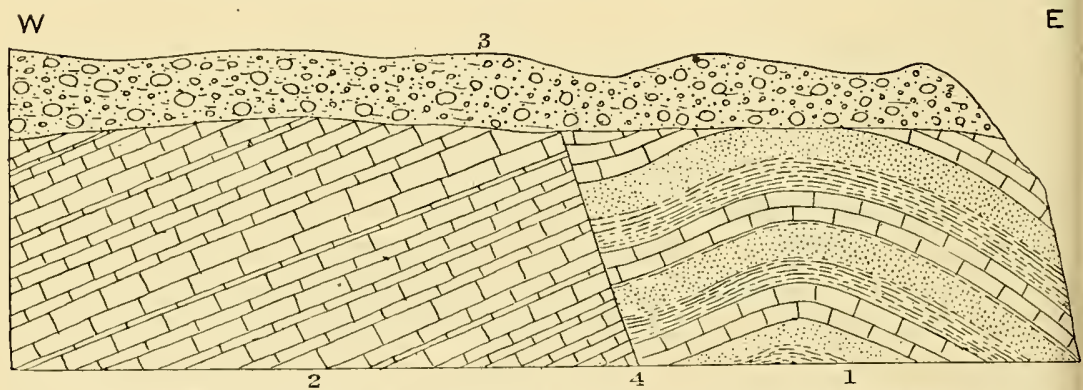

F1G. 16.-Sketch section of north wall of Meadow Valley Canyon, 3 miles southwest of mouth of Hackberry Canyon, showing a pre-Pliocene fault.

1. Interbedded pink and yellow sandstones, sandstone shales, and bluish-green siliceous limestones.

2. Homogeneous thin-bedded siliceous limestones (Carboniferous).

3. Pliocene (?) conglomerate.

4. Pre-Pliocene fault.

have been displaced by recent faults, which are directly expressed in the topography (fig. 15). Farther south, a short distance down the main Meadow Valley Canyon (or, as it is called at this point, Mormor Canyon), the horizontal conglomerate overlies unconformably the 
Paleozoic limestones and sandstones. At this point a fault has displacerl the Paleozoic rocks, but not the overlying conglomerates, showing that it ocenred before the deposition of the latter (fig. 16). A short distance south of here the horizontal sandstone is brought to the bottom of the canyon by the dipping down of the contact between it and the lower formations, and from liere to the neighborhood of Moapa-or West Point it is the principal formation exposed in the valley, the older Tertiary deposits not being observed and the Paleozoic rocks only in patches.

From Kane Spring southward to Graperine Spring, a distance of about 3 miles, there is a very interesting section (fig. 17). Above the upturned and eroded Paleozoic limestones occur the consolidated brownish sandstones, grits, and conglomerates of the horizontal series. The conglomerates contain pebbles of limestone, chert, and quartz from the Paleozoic series, white rhyolite from the basal rlyyolite series, and characteristic red lava from the dacite-rhyolite series (PI. VI, B). There has been a slight local folding of the brown sandstones and conglomerates, which seems to have been partly cansed by the advent of a considerable sheet of rhyolite. This rhyolite orerlies the sandstones and has also cut into them as sills. Prob ably, however, part of the fold. ing took place before the intrn sion. At Graperine Spring there has been a late faulting which has displaced the lava as well as the sandstones, and here also the upturning of the strata has been

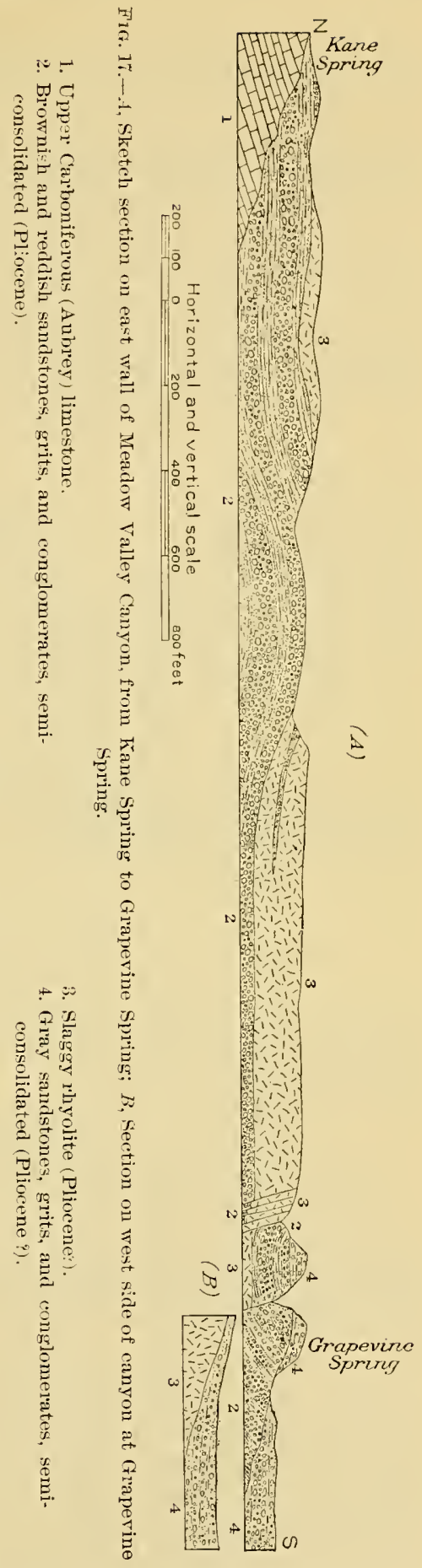

Bull. 208-03-10 
greatest, resulting in a local dip of as much as $45^{\circ}$. Lying upon the mpturned edges of the brown sandstones here, and also upon the later rhyolite, is a series of consolidated grits and conglomerates, distinguished by a gray color as opposed to the reddish and brown colors of the beds below (fig. 18). Sonthward from Grapevine Spring to Moapa, the horizontal gray sandstone and conglomerate is continnally observed overlying the red and yellow series, which is again horizontal and mostly conformable to it.

The very slight folding of all the beds which have been described under the last head separates them from all the underlying unconformable Tertiary series. Their position, structure, and distribution show that they are probably lake beds, and, indeed, they lie, partly

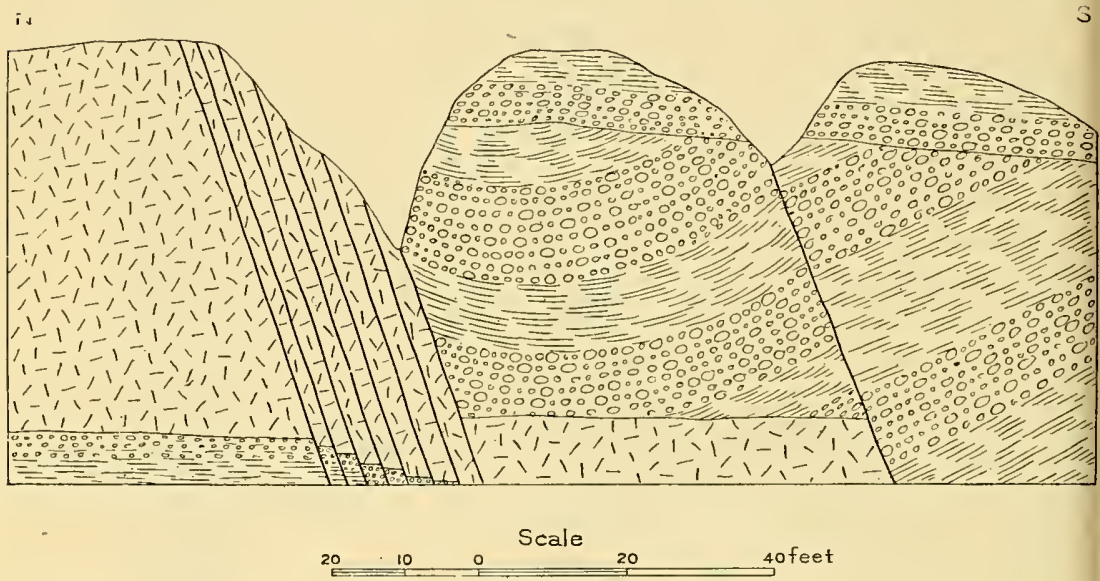

FıG. 18.-Sketch section of west wall of Meadow Valley Canyon at Grapevine Spring, Enlarged from fig. 1\%. Showing fault gullies in Pliocene rocks.

at least, in inclosed rock basins. These beds are provisionally referred to the Pliocene."

\section{PLIOCENE RHYOLITES.}

In the section between Kane Spring and Grapevine Spring the moderately thick sheet of rhyolite above noted is of an age intermediate between the lower brown Pliocene sandstone series and the upper gray Pliocene series, since it overlies the one and underlies the other. It is a glassy rock, and rery little can be told of its composition.

\section{PLEISTOCENE RHYOLITE AND BASALT.}

At several points very recent lavas are seen, which form the latest phase of rolcanic activity in this region. In the canyon near the northern end of the broad basin which lies northeast of the Mormon Range the topmost rock at one point was found to be a slreet of 
pyroxene-olivine-basalt, overlying with an irregular contact stratified voleanic sand apparently belonging to the dacite-red rhyolite period.

Near the sonthern end of the same basin a thin sheet of glassy tordrillite comes down into the valley, covering the hills in such a way as to show that the present topography was developed before the lava effusion.

At Hackberry Canyon thin sheets of glassy lava overlie the horizontal Pliocene sandstones and conglomerates. Specimens of these sheets, taken at different but neighboring points, proved to be tordrillite and pyroxene-olivine-basalt. The two seem to be practically contemporaneous, and both must be regarded, from their position and

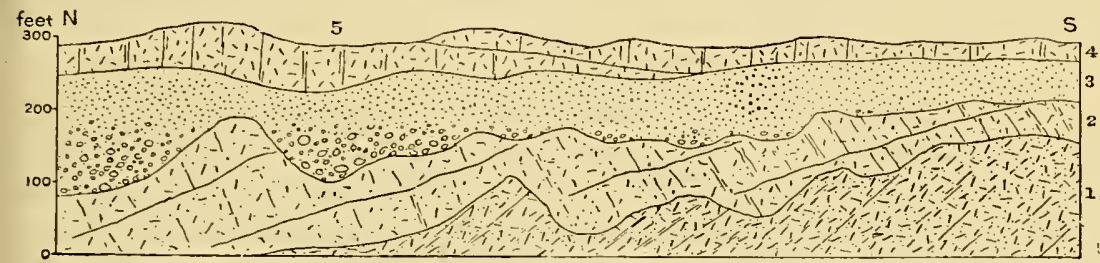

Fig. 19.--Sketch section of wall of Hackberry Canyon at Hackberry Spring.

1. White decomposed rhyolite.

2. Pyroxene-andesite.

3. Conglomerate and soft sandstone (Pliocene?).

4. Thin-bedded, slaggy olivine-basalt (Pleistocene).

5. Thin-bedded slaggy tordrillite (siliceous rhyolite) (Pleistocene.)

their relation to the underlying rocks and to the topography, as Pleistocene (fig. 19).

\section{PLEISTOCENE GRA VELS.}

Through all the rocks previously described, except part, of the Pleistocene rhyolites and basalts, the drainage has eut a canyon in places as much as 2,000 feet deep. The detritus removed by this eutting has chiefly been earried down the valley and out to the Colorado River, but a certain portion still floors the valley bottom.

\section{SEQUENCE OF EVENTS.}

Out of the complieated conditions observed at so many points in the valley of Meadow Creek, the following rough sequence of events may be provisionally laid down:

1. Deposition of the Paleozoic series of quartzites and limestones.

2. Elevation of this series to a land mass and the erosion of the rocks to produce a system of mountains and valleys. This was attended by little or no folding.

3. Pouring out of great masses of white biotite-rhyolite (early Tertiary.)

4. The formation of a series of water-latd rhyolitic sandstones and 
tuffs, interbedded with thin sheets of rhyolite and rhyolite breceias. This whole series is roughly estimated at 4,000 feet thick and at the top contains relatively more tuffs, while at the bottom there are relatively more lavas. Several slight unconformities and many slight erosion gajs occur in the series.

5. Folding to a considerable degree of the whole crust.

6. Explosive eruptions of pyroxene-andesites and latites of molerate extent.

7. The formation of a series of water-laid brown volcanie tuffs or sandstones and breceias, with interbedded quartz-bearing volcanics, chiefly dacites and reddish rhyolites. The sandstones were relatively thick at the bottom of the series, the roleanies at the top. The entire thickness of the series is estimated at 3,500 feet. There are some petty erosion intervals.

S. General folding, comparatively gentle.

9. Deposition of at least 2,000 feet of brown or red conglomerates and soft sandstones, which are accompanied by very few volcanic flows and so are distinct from the preceding formations. They have remained nearly horizontal and are probably, in large part at least, lake beds. They have been referred to the Pliocene.

10. Drainage of the Pliocene lake, erosion and slight local folding in the Pleistocene.

11. Ontponring of thin sheets of rhyolite, tordrillite, and pyroxeneolivine-basalt.

12. The formation of a small amonnt of high stream gravels.

13. Cutting down of the canyon bed to its present position.

'The thickness of the basal rhyolite is not known. A. very roughly estimated section of the overlying formations is as follows:

Section in Meadow Talley Canyon.

Rhyolite tuff series

Andesite

4,000

Rerl lava and sandstone

600

Pliocene sandstones and conglomerates

3,500

2,500

Total

10,600

The sncorssion of lavas, so fal as can be made out in this confused section, is as follows: Biotite-rhyolite, pyroxene-andesite, biotitehornblende-quartz-latite, biotite-hornblende-dacite, quartz-latite or red rhyolite and tordrillite, pyroxene-olivine-basalt, glassy rhyolite or tordrillite.

\section{MEADOW VALLEY RANGE.}

The Meadow Vralley Range lies opposite the Mormon Range, on the west sicle of Meallow Valley. It is comparatively low and irregular. At the north end it passes into the IIighland Range and at the sonth 
into Las Vegas Range, with which it forms a $V$. Near this point it becomes broader and divides into several parallel petty ridges.

\section{SEDIMENTARY ROCKS.}

The Meadow Valley Range is composed chiefly of stratified rocks.

\section{CAMBRIAN.}

'The mining camp of Delamar is sitmated on the western slope of the Neadow Valley Range. According to Mr. Emmons ${ }^{a}$ the range here consists of limestones underlain by heary quartzites, these formations corresponding to the Cambrian quartzites and the limestones. There is a belt of shale, as at Pioche. These rocks are continuous northward into the Highland Range, but on the east are overlain by later voleanies.

\section{CARBONIFEROUS.}

Along the road which erosses the range from Moapa toward Pahranagat Valley an excellent section is obtained. The rocks are Paleozoic limestones and form two synclinal ridges, with an interior anticlinal valley between. The eastern part of the section consists of rather thin-bedded limestone, full of chert nodules. These apparently overlie the strata of the westernmost ridge, which are dark-blue, semicrystalline limestones, also full of chert nodules, and containing some quartz veins. This is often fetid, and is more massive and of older appearance than the other limestones of the section.

Where the road cuts through the low eastern ridge the following Upper Carboniferous fossils were found, as determined by Dr. Girty:

Fusulina cylindrica.

Archæocidaris sp.

Productus prattenianus.

Productus semireticulatus.

From the apparently lower rocks of the western ridge the following fossils were collected (also Upper Carboniferous):

Zaphrentis sp.

Productus? sp.

Spirifer sp.

Seminula sp.

Macrocheilina? sp.

Between the western ridge and the eastern face of the New Mountains to the west, which are an important branch of Las Vegas Range, a low ridge runs along the middle of the valley, joining the more massive mountains on the south at the angle of the $V$. This ridge 
is composed of fetid thin-bedded limestones, like those just described. The following fossils were found by Dr. Girty to be Upper Carboniferous:

Fusulina cylindrica.

Syringopora multattennata.

Productus semireticulatus.

Productus prattenianus.

Pleurotomaria sp.

PLIOCENE.

The Pliocene of the southern portion of Meadow Valley ${ }^{a}$ extends westward and forms the flanks of the Meadow Valley Range, abutting unconformably against the upturned Paleozoic limestones. The rocks eonsist of horizontal red and white sandstones and occasional eonglomerates, varied a short distance east of Moapa by a white consolidated voleanic ash. The Pliocene strata occupy a broad belt running north and south. They are locally slightly folded, dipping as much as $10^{\circ}$, but in general are horizontal.

On the western side of the range, in the bay between it and the New Mountains and Las Vegas Range, the same Pliocene sandstones oceur.

Some distance north from Moapa and just northwest from Hackberry Spring, as seen from Meadow Valley, the Pliocene deposits seem to rise along the flanks of the Paleozoic Range until they occupy broad areas covering the limestones on the summits of the range, they themselves being capped by volcanics.

\section{IGNEOUS ROCKS.}

In the northern half of the range a great part of the rocks exposed at the surface seem to be voleanies, undonbtedly belonging to the Tertiary and Pleistocene flows already described in Meadow Valley Canyon.- They probably are associated with Tertiary sediments derived from them, like the beds in the locality mentioned.

\section{STRUCTURE.}

The northern end of the range seems to be chiefly volcanic, from which the mnderlying Paleozoies emerge in places. South of here appear voleanics and associated Tertiary sediments, and the main ridge in the whole southern part of the range eonsists of folded Paleozoic limestones. The structure in the Paleozoic limestones consists of open parallel anticlines and synclines, generally of no great width or depth. North of the valley of the Muddy the central ridge is synclinal, with an anticline closely adjacent to it on the eastern flanks of the ridge. Irregularities in the erosion sometimes bring this anti-

a See descriptions of Meadow Valley Canyon, Mormon Range, and Virgin Range, pp. 131, $135,143$. 
cline to the erest of the ridge, as shown in a section observed northwest of Kane Spring. Just west of Graperine Spring, however, the syncline forms the summit.

South of Mudily Valley, on the road which runs westward from Moapa, the broadening and dividing range shows two principal synelinal ridges with an intervening nonpersistent anticlinal valley. The syncline of the westernmost of these pidges appears to be contimuous with the main synelinal ridge farther north. Besides these main folds sereral petty ones were observed to the east of the easternmost large syneline, consisting of slight alternating anticlines and synclines. In the whole section no less than six adjacent open folds were observed, the synclines generally forming rirges, the anticlines depressions. West of the westermmost syncline, a low Carboniferous ridge in the valley has a westerly dip, and in the depression between it and the synclinal ridge is an anticline, as is shown in the mountains which terminate the depression between the two ridges a few miles farther sonth (fig. 20).

\section{PAHROC RANGE.}

The Pahroc is a comparatively short range of no great height, lying immediately west of the Highland Range and haring a due north-south trend. Its length is not over 25 miles and its width not more than 5 or 6 miles. Only the northern part of the range was seen by the writer, and that from a distance of several miles.

IGNEOUS ROCKS.

Mr. Gilbert a reports that the Pahroc Range, on the road from Hiko to Pioche, is of lava, which extends a number of miles north and south.

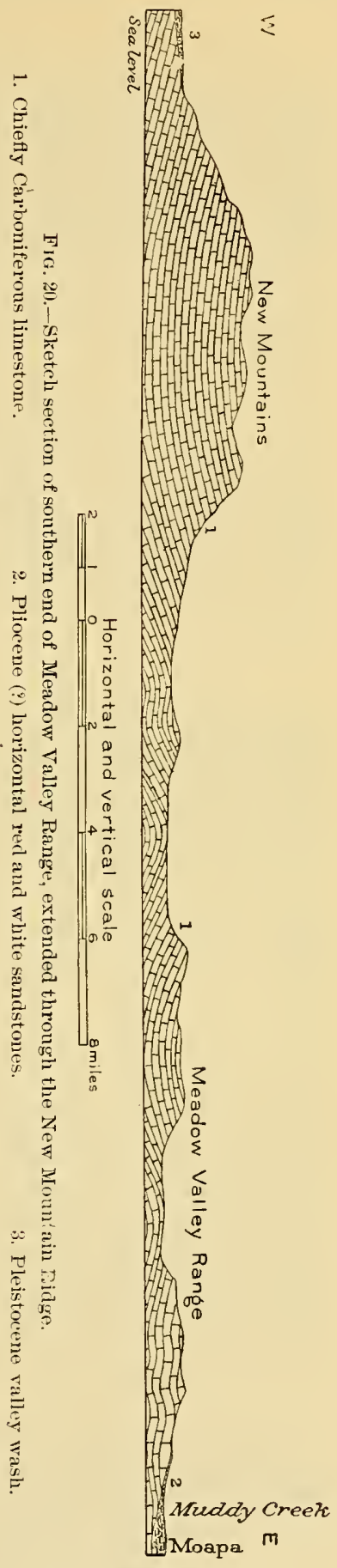

u U. S. Geog. Surv. W. One Hundredth Mer., Vól, III, p. 123. 
SEDIMENTARY ROCKS.

As seen from the north, the northern end of the range is made up of stratified rocks of moderately thick bedding, evidently limestones. These rocks extend for some distance farther south. Indging from the rocks fomnd just north of here, in the low hills which have been described as forming the connection between the Pahroc Range and the southern end of the Egan Range a short distance northwest of Pioche, ${ }^{a}$ the rocks of the Pahroc Range thus exposed are perhaps, in part at least, Devonian. The Silurian may possibly be represented.

\section{S'T'RUCTURE.}

The limestones which constitute the northern end of the range seem, when viewed from a distance, to be bent into a single, regular, anticlinal fold, which strikes parallel to the north-sonth trend of the range. The strmmit of the range appear's to comprise the axis of the fold, and from this the rocks dip on both sides at a gentle angle, averaging about $15^{\circ}$.

\section{HIKO RANGE.}

The Hiko Range lies next sonthwest of the Pahroe Range, with which it is joined at several points by low connecting hills. It has a north-sonth extent of abont 30 miles, and, like the Pahroc Range, its general trend hardly diverges from a due north-sonth line. On the west the Hiko Range is connected by a series of hills with the Pahranagat Range, and this series of hills continued farther west comnects these ranges with the Timpahnte Range and the Worthington Mountains. Like the Palmoe Range, the Hiko Range is comparatively low.

SEDIMENTARI ROCKS.

Most of the Hiko Range is composed of limestone of Silnrian and Devonian ages. Mr. Gilbert ${ }^{b}$ first described Silurian fossils from Fossil Butte, just west of the main range. Subsequently Mr. Wal$\operatorname{cott}^{c}$ made an investigation of the paleontology here, and described many species of fossils. According to Mr. Wralcott there is exposed in Fossil Butte the Pogonip limestone of the Eureka series, overlain by the Eureka quartzite. Near Ifiko he found shaly limestone, overlain by arenaceous limestone carrying a Deronian fauna.

IGNEOUS ROCKS.

Aecorling to Mr. Gilbert, ${ }^{d}$ there are a few small bodies of lava in the range.

a See description of Egan Range, p. 49.

$b$ U. S. Geog. Surv. W. One Hundredth Mer., Vol. II;, p. 181.

c Mon. U. S. Geol. Survey Vol. XX, p. 195.

a Op. eit., p. 123. 
STRUCTURE.

Mr. Gilbert" found in the IIko Range north of Fossil Butte a westerly dip, but south of this point an easterly dip. There has been no folding; and therefore there is a scissors fault ${ }^{b}$ transverse to the range at about this point. 'This same peculiar structural feature, according to $\mathrm{Mr}$. Gilbert, is characteristic of all the ridges west of here as far as the Timpahute Range.

\section{PAHRANAGAT RANGE.}

The Pahranagat Range lies next sonthwest of the Hiko Range, with which it is connected at its northern end by Fossil Butte. From here it extends southward in a general south-southeasterly direction for about 40 miles, where it is separated from the Arrow Canyon Mountains by a comparatively short transverse stretch of desert valley. The highest mountain in the range is Quartz Peak, at its northern end.

\section{SEDIMENTARY ROCKS.}

Mr. Gilbert ${ }^{c}$ found Silurian fossils in the northern end of the range. Mr. Walcott ${ }^{d}$ found on the eastern side of the Pahranagat Range limestones which he regarded as possibly belonging to the Lone Mountain series of the Silurian. In Quartz Peak, just west of here, he found a fine exposure of Silurian strata comprising the following divisions:

Section at Quartz Peak.

Lone Mountain Niagara

Feet. 535

Lone Mountain Trenton.

Eureka

Pogonip

Total

2,200

South of Quartz Peak he found a great thickness of limestone, nearly 8,000 feet in all, broken only by thin beds of yellow sandstone, the heaviest not over 100 feet in thickness. In this great thickness of limestone he found no lithologic variation sufficient to base divisions upon. From the fossils contained he found that the limestone ranged from Carboniferous through the Deronian into the Silurian. It was impossible to draw any line of demarcation

$b$ The writer has employed this term thinking that it was already in use. Mr. Gilbert, how. ever, who has examined the manuscript, believes that the term is original here, and it is therefore defined as a fault whose movement is like that of a pair of scissors when opened, there being on the fault plane an axis where the differential movement is nothing, while on one side of this axis the morement is the reverse of what it is on the other. Therefore the rocks on the two sides of the fault plane will acquire tilts in opposite directions.

c Op. cit., pp. $168,181$.

a Mon. U. S. Geol. Survey Vol. XX, p. 196. 
between the Silnrian and Devonian, but dividing the rocks as well as might be the following thicknesses were found:

Carboniferous

Devonian

2,160

Silurian

IGNEOUS ROCKS.

Mr. Walcott noted occasional outbursts of acidic lavas in the Pahranagat Range, and Mr. Gilbert describes two large eruptions of rhyolite, one at the north end of the range and the other at Logan Pass at a cross fault.

\section{STRUCTURE.}

According to Mr. Gilbert the cross fault above-mentioned is a scisscors" fault, having such differential movement that all the strata to the north acquired a westerly dip, while those to the south are tilted toward the east. That portion of the range which lies north of the cross fault is divided into separate north-sonth ridges by north-south faults whose downthrow has been mniformly to the east. South of the pass the strata have a single, monoclinal, easterly dip.

\section{ARROW CANYON RANGE.}

The Arrow Canyon Range has not been visited and was only seen from some little distance. It is a continuation northward of that branch of Las Vegas Range which has been called the New Mountains. It has a general northwesterly trend, parallel with the main west arm of Las Vegas Range, and has a length of more than 20 miles. On the north it is separated from the Pahranagat Range by a narrow, transverse valley.

As seen from several points, the Arrow Canyon Mountains are made up of stratified rocks, well banded, but eroded so as to form massive chiffs. This is the appearance offered by the heavy Carboniferous limestone of this region, as shown just south of here in the New Mountains. It is possible, therefore, that the bulk of the range is Carboniferons. To the north also, in the Pahranagat Range, Carboniferons rocks are present in considerable quantity.

The strike of the strata is parallel with the trend of the range. Along nearly the whole of its western side the rocks are seen to dip in to the range eastward at angles of from $15^{\circ}$ to $20^{\circ}$. Farther north an area of apparently horizontal strata can be distinguished; so that the general structure of the range may be synclinal, corresponding to that of the New Mountains to the south, or it may be a general monocline dipping eastwardly, like the Pahranagat Range. 


\section{LAS VEGAS RANGE.}

Las Vegas Range forms an irregular group in the central portion of southern Nevada, lying just east of another irregular group, the Spring Mountain Range. Las Vegas Range has hardly any definite form, but a prolongation on the northwest gives it rather the aspect of having a northwesterly trend. This prolongation forms one arm of a rough $V$, of which the southern portion of the Meadow Valley Range forms the other, the two miting in a rugged eluster of mountains in the neighborliood of Gass Peak. Bisecting the angle of the $V$ is a high, rocky ridge, which was not delineated on the Wheeler survey maps, and which the writer will call, for the purpose of description, the New Mountains.

It is peculiar that so prominent a ridge should have escaped mapping, for it comprises some of the highest mountains in the southern part of the State. On the eastern face of the New Mountains is a sharp scarp of about 4,000 feet, rising from the foothills. This scarp is often perpendicular for great heights, and is apparently inacessible. The roeks are composed of massive limestone, beautifully banded. To the north the New Mountains become lower and are separated from the Arrow Canyon Mountains, which are really a portion of the same general range, by a transverse valley.

The southwest face of Las Vegas Range, facing Las Vegas Valley, also possesses a steep slope, reaching $45^{\circ}$ at some points.

No igneous rock whatever was found in Las Vegas Range.

SEDIMENTARY ROCKS.

CAMBRIAN.

From a point about 6 or 7 miles north of Mormon Wells, which is on the wagon trail crossing the southern portion of the range in a northeasterly direction, southward probably to the end of the range, the roeks consist chiefly of bristly weathering siliceous, crystalline, cherty limestone, often having a peculiar mottled strueture, which is probably due to the rock having been originally made up of coral, now reerystallized and unidentifiable. This rock is lithologically identical with Cambrian limestones in the Highland Range west of Pioche.

On the divide south of Mormon Wells there are found thin, brown and red, sandy, and limy slates, changing to thin-bedded limestones. These contain fossil remains, which are determined by Mr. Walcott as belonging above the Olenellus zone and probably to the Middle Cambrian. Fragments of white quartzite were found in the drift here, which also suggest the existence of Lower Cambrian quarzites in the mountains.

The same ancient-appearing limestones are continuously exposed along the road above mentioned, southwest nearly to Las Vegas Valley. At this point they give way to the underlying Silurian. 
Mr. R. B. Rowe noted that the first ridge west of Sheep or Gass Mountain (which ridge is here considered the northernmost part of Las Vegas Range) consists of beds of dark-blue and gray limestone, with white and reddish sandstone. Fossils collected in this locality were found by Dr. Girty to be chiefly Deronian, but to contain one Cambrian specimen. Therefore, probably both the Cambrian and the Devonian are here represented.

SILURIAN.

In the valley just northeast of Gass Peak, at the locality above mentioned, occur cherty, blue-gray, and siliceous, sometimes green and shaly, limestones similar to those of the Cambrian. The few fossils obtained from these rocks are regarded by $\mathrm{MI}_{\mathrm{r}}$. Walcott as representing a horizon abont the base of the Pogonip (Ordovician). Mr. Walcott determined Orthis perveta (?) and the tail of a trilobite belonging to the genus Bathyurus.

From this point to the northwestern end of the range the rocks appear to be all limestones, of the same ancient character as those already described, as specimess obtained here and there show. A similar limestone extends still farther northwest into the southern end of the Desert Range, and was followed continually along Las Vegas Valley to Indian Spring in the Spring Mountain Range. At Indian Spring Ordovician fossils were found.

About 6 iniles northeast of Corn Creek, near the mouth of the first important canyon, Mr. R. B. Rowe found about 200 feet of dark blue limestone, containing immense numbers of gasteropods of enormous size, together with a few corals. The fossils collected by Mr. Rowe were determined by Dr. Girty as Ordovician.

DEYONIAN.

The existence of Devonian limestones in the ridge west of Sheep or Gass Monntain, at the north end of the range, has already been mentioned.

CARBONIFEROUS.

The Cambrian rocks in the neighborhood of Mormon Wells are apparently separated by a heavy east-west fault from the unmetamorphosed massive blue limestones which make up the greater portion of the New Momntain ridge and the anxiliary ridges to the east. In one of these auxiliary ridges a collection of fossils was obtained, which were found by Dr. Girty to be Upper Carboniferous. Nonorth-sonth fanlts were determined, and the gentle folding, resnlting in slight, alternating synclines and anticlines, suggests that rocks of the same horizon make up the New Monntains to the west.

According to the notes of $\mathbf{M} r$. R. B. Rowe, the mountains east of Las Vegas contain the Lower Carboniferous, the Carboniferous red 
beds, and the Upper ('arboniferous limestone, so far as can be seen rom Las Vegas ranch.

From Sheep or Gass Mountain, in Las Vegas Range, speeimens of Goniatites were bronght and given to $\mathrm{Mr}$. Rowe. The fossils seem to :ome from a soft shale. ${ }^{\prime \prime}$

About 2 miles west of Sheep or Gass Mountain, in a spur of that ange, about 5 or 6 miles north of the road leading from Corn Creek o Indian Creek, fossils were collected which were determined by Dr. Girty as Upper Carboniferous or Pennsylvanian, and in the same reneral region other fossils were collected which were determined.by Dr. (Girty as Lower Carboniferous or Mississippian. The ridge conists mainly of low hills, which are eut extensively by canyons.

Terfiary.-Mr. R. B. Rowe's notes on the. Tertiary areas follow. At Las Vegas and in the immediate vicinity there are white beds of probably roleanic ash. From the valley some distance west of Las Negas mastodon teeth were collected. About midway between Corn Creek and Tule Springs some mastodon teeth and bones have been found. They were situated in a clay bank some 10 or 15 feet high.

East of the range, at the summit of the pass between Las Vegas Valley and Muddy Creek, about 12 miles east of Las Vegas, are red and yellow Tertiary beds which dip toward the Colorado River at an angle ranging from $4^{\circ}$ to $5^{\circ} .^{b}$

The valley between Las Vegas, Tule Springs, and Corn Creek seems to be filled with lake deposits. About Tule Springs, and from there up the valley, are probably the remnants of an old, dry lake berl or playa. The deposits do not have the appearance of the Tertiary lake deposits, but resemble exactly the clay deposits in the present dry lakes. Underlying these is a gravel or talus deposit. The eroded drr lake beds extend from Corn Creek to Indian Creek.

PLEISTOCENE.

In Las Vegas Valley the Tertiary deposits so abundantly exposed in the region of Meadow Valley are hidden beneath Pleistocene accumulations. This valley is of the usual type of the desert valleys of Nevada, with guleh dumps fringing the mountains, and in the center a nearly level area of hard mud flats, or a playa. There has been no dissection of these deposits to reveal what lies beneath.

\section{STRUCTURE.}

The general folding in Las Vegas and New mountains has apparently resulted in a rough, shaliow, disturbed northeast-southwest striking syncline. The nearly horizontal area in the central portion of the range

a These may be the same as some specimens of Goniatites recrived by Dr. Girty from Mr. Rowe's collection after the death of Mr. Rowe. They were considered by Dr. Girty as Lower (?) Carboniferous.

b'These are the same as described by the writer under" the head of "Meadow Valley Range." 
belongs in the trough of the syncline, while at the northwestern end the dip of the northwest limb of the fold becomes $30^{\circ} \mathrm{or}^{\circ} 45^{\circ}$ sontheasterly, or eren more. The syneline is succeeded by a nueh sharper anticline along the narrow valley separating the Desert and Las Vegas ranges. In the broad central portion of the syneline there has been irregular minor folding, chiefly along east-west lines, the dips generally being muler $15^{\circ}$. At the sonthern end of the range the general strike appear's to become east and west, and the dip about $20^{\circ}$ north.

The main fold of Las Vegas Range, being at right angles to the general trend of the mountains, puns across Las Vegas Valley and is probably to be found in the Spring Mountain Range on the other side, where, indeed, it was thought to have been identified by the writer. Similarly, the various parallel ridges of limestone which run transverse to the general trend of the range are broken by the valley and find their continuation in the Spring Nountain Range opposite. Las Vegas Valley, therefore, differs from the most ordinary type in the Great Basin in that it is transverse to the general strike of the rocks.

In the region north of Mormon Wells there is a marked change from massive, maltered, blue limestones, probably belonging to the Carboniferous, to altered, aneient-appearing, crystalline limestones, associated with shales carrying Cambrian fossils. The areas ocenpied by these different rocks may be easily sketched, since the erosion of each has resulted in peculiar forms. The Cambrian rocks have rounded topography, without scarps or evident structure, and weather brown, while to the north the blue-gray Carboniferous rocks have sharp scarpecl outlines with perfectly visible stratification. Inasmuch as the strike of the folds is here north and south, which carries the Carboniferous limestone direetly into the Cambrian, there must be a fault betweon the two horizons, and this fault must have, as sketehed, a direetion somewhat north of west. The vertical displacement of the fault may be several thousand feet and has resulted in a downthrow to the nortl. There is no distinet break in the topography along the fault line.

The bold east faee of the New Mountains suggests a more recent heavy fault, to whose displateement the scarp may perhaps be directly due.

'The following notes on the structure were made by $\mathrm{Ir}_{\mathrm{r}}$. R. B. Rowe:

A sketch of the monntains of Las Vegas Range east of Las Vegas shows a constant dip of about $40^{\circ}$ to the east. A hypothetical fault is also shown, whieh has the effect of bringing np the lower strata on the east side.

Niear Corn Creek the rocks strike east and west and dip uniformly $30^{\circ}$ to the north.

As has been noted, there is apparently a series of old, dry lake deposits in Las Vegas Valley, which are now being eut into by the arroyos. These, taken together with the fact that the surface ]ises about 100 to 600 feet between Tule Springs and Corn Creek 
and that the same beds rise still higher beyom Corn Creek, indieate a comparatively reeent elevation of the upper end of Las T egas Valley.

On the east side of Las Vegas Range, the lact that the Tertiary beds dip slightly toward the Colorado at an angle of $4^{\circ}$ or $5^{\circ}$ suggests that the Las Vegas Range has been slightly raised since the general elevation of the region.

\section{TIMPAHUTE RANGE.}

The following summary of the Timpahute Range is taken from Mr. Gilbert's description. ${ }^{a}$

The Timpahnte Range lies next west from the Pahranagat Range and immediately south of the Worthington Mountains. Its general trend is a little east of north and its length about 30 miles. The highest portion is Timpahute Peak, near the sonthern end.

\section{SEDIIENTARY ROCKS.}

At the south end of the range Mr. Gilbert ${ }^{b}$ measured a thickness of 2,325 feet of strata showing the following section:

Section at south end of Timpahute Range.

Feet.

1. Heavy-bedded gray limestone, light and dark 400

2. Yellow argillaceons shale:

a. Yellow shale, 350 feet

b. Yellow sandstone, 6 feet

c. Yellow and green shale, with fillets of fossiliferous limestone

(Conocoryplie), 500 feet

3. Purple, ripple-marked, vitreous sandstone, with bands of siliceous shale- 1,000

Total

2,325

The fossils found in the shales above the basal quartzite fix the formation as Cambrian, and the basal quartzite is the same as the basal quartzite of the Highland Range Cambrian section and also the Prospect Mountain quartzite at Enreka. ${ }^{c}$

The northern portion of the range does not appear to have been described. Both to the east and to the west of it, in the Worthington Mountains and in the Pahranagat Range, aro Silurian rocks, in part Lower Silurian. It is probable, therefore, that this north end of the Timpahnte Range is in part Silurian and in part also Cambrian.

\section{IGN_OUS ROCKS.}

According to Mr. Gilhert, ${ }^{d}$ Timpahnte Peak is the center of a massive eruption of rhyolite, which connects with a similar eruption northeast of here in the Pahranagat Range by a line of rolcanic hills which runs across the intervening ralley.

a U. S. Geog. Surr. W. One Hundredth Mer., Vol. III.

$b$ Ibid., p. 169.

c Tbid., p. 181; C. D. Walcott, Bull. U.S. Geol. Survey No. 30. 1. 36, Bull. 81, p. 156; Arnold Hague, Hon. U. S. Geol. Survey Vol. XX, pp. $4 \mathbf{6}, 189$.

"Op. eit., p 123. 
STRUCTURE.

The volcanic ontburst at Timpahute Peak, according to Mr. Gilbert, ${ }^{a}$ is on the line of a scissors fanlt, which has so displaced the strata that to the north of this fault they dip uniformly west while to the south they dip uniformly east. This fanlt is on the same line as a similar fault northeast of here in the Pahranagat Range, and another still farther northeast in the IIiko Range, and in each of these ranges the peculiar tilting of the strata above noted is found. In the Timpahute Range the sedimentary rocks sonth of the line of fanlting are separated by north-south vertical faults which have a uniform downthrow to the west. Mr. Gilbert gives a section of the range showing this structure.

ORE DEPOSITS.

In the Cambrian shales at the southern end of the range, according to $\mathrm{Mr}$. Gilbert, ${ }^{b}$ are metalliferous veins.

\section{DESERT RANGE.}

The Desert Range is somewhat irregular and of moderate height. It is divided into two branches by an interior valley which reaches northward from the north end of the spring Mountain Range. At its north end the Desert Range passes into the ralley which separates the 'Timpahute from the Pahlanagat Range.

SEDIMENTARY ROCKS.

The south end of tho Desert Range was visited by the writer. It consists of altered, erystalline, light-gray limestone, brown weathering, often full of rounded, detrital quartz grains. There are also beds of black, dense limestone. Similar limestone contains Ordovician (Pogonip) fossils in the western part of Las Vegas Range. This limestone series can be distinguished extending northward fully halfway to the end of the range, at least 20 miles. It is possible that it may contain some of the Cambrian limestones which are hạdly separable lithologically from the overlying Silurian.

Mr. F. B. Weeks ${ }^{c}$ followed along the west side of the range and crossed the north end, at Mud Spring, in 1900. He fonnd the bulk of the range to consist of stratified rocks, which he was inclined to consider as Silurian and Devonian, while on the north end these strata are replaced by rolcanic rocks.

The following notes were made by Mr. R. B. Rowe: ${ }^{d}$

SILURIAN.

About \& or ! miles northeast of Indian Creek, in the first range on the west side of the dry lake which lies east of Indian Creek, and about

" U. S. Geog. Surv. W. One Hundredth Mer., Vol. III, pp. 38, 39.

$b$ ibid., p. 181.

c Personal communication to the writer.

a'Taken from his notebooks after his death by the writer. 
$t$ miles north of the road from Indian Creek to Corn Creek, the section consists chiefly of dark-blue limestone, with light-blue arenaceous limestones and shaly limestones with chert layers. There are also a few layers of white saudstone, resembling quartzite. Fossils collected were regarded by Мr. Rowe as Ordovician, and his impression was corroborated by Dr. Girty's examination.

The rocks $t$ miles east of Indian Creek are light-gray, arenaceous, and dark-blue limestones, with layers of chert and white sandstone, which is nearly a quartzite, as it is farther east. These rocks were regarded by Mr. Rowe as probably Lower Silurian.

DEVONIAN.

About :3 miles northeast of Indian Creek, in low hills south of the road leading to the lower end of Pahrunagat Valley, and north of the road to Corn Creek, fossils were found in loose blocks of dark-blue limestone. These were regarted by Mr. Rowe as Middle Devonian, and were determined by Dr. Girty as probably Lower Devonian.

\section{STRUCTURE.}

At its southern end the range is separated on the southwest from Las Vegas Rauge by a narrow anticlinal valley, the rocks of the Desert Range dipping northwest on the northwest limb of the fold. The reneral strike here is northeast, and a series of parallel ridges has been eroded parallel to the strike. The dip continues in the same direction as far as the interior valley dividing the two chief branches, but becomes flatter, and the strike swings around more toward the north. On the western branch of the range, as seen from the south, the rocks are partly horizontal and partly strike a little east of north aud dip uniformly west at angles not exceeding $15^{\circ}$.

The valley lying between the ridge lying west of Sheep Mountain and the lange next west, or between Las Vegas Range and the Desert Range, was regarded by $M r$. Rowe as auticlinal in structure. ${ }^{a}$ The mountains on the two sides dip in opposite directions. On the westeru side Ordovician fossils were found on the eastern side Carboniferous and Cambrian. There are probably large and numerous faults concealed by the talus. There is a great deal of plainly observable faulting at right angles to the strike. These faults are generally not Iarge, but are abundant. ${ }^{b}$

\section{REVEILLE RANGE.}

The Reveille Range is separated on the north from the Pancake Range by a narrow transverse gap at 'T'win Springs. It extends southeastward from here a distance of about 60 miles, running obliquely across to the Timpahute Range.

$a$ This is the same anticlinal ralley that was previonsly observed by the writer (see above) (J.E. S.).

$b$ This whole paragraph is from Mr. Rowe's notes.

Bull. 208-03-11 


\section{TOPOGRAPHY.}

The range is somewhat irregular in its course and extent, which arises from its being made up largely of volcanic outbursts. This also accounts for the prevalent type of topography, which is similar to that of the Pancake Range to the north, showing low peaks and broad, gently sloping mesas, which are sharply cut into by the valleys eroded since the period of lava effusion. At one or two points, however, such as that near the old mining camp of Reveille, patches of older Paleozoic strata, and of older volcanics than those which form the mesa-like forms, emerging from the younger lavas, offer a series of sharp, irregular peaks and better developed valleys.

\section{SEDIMENTARY ROCKS.}

According to Mr. Gilbert, "the Paleozoie strata which form the core of the Reveille Range are exposed at but two points, one at Reveille and the other 60 miles farther south. In both these cases the rocks dip to the west, the dip being steeper at the more southern exposure. At Reveille the strata are of limestone and quartzite.

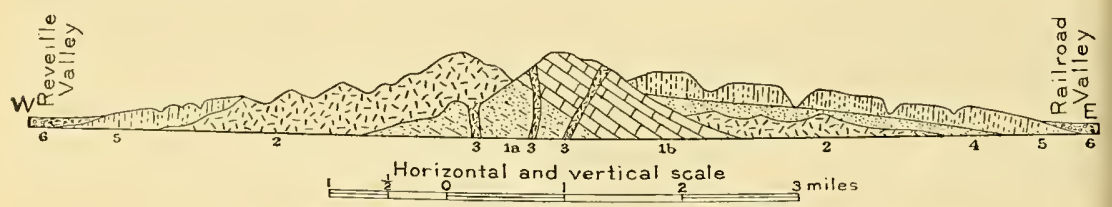

FrG. 21.-Generalized sketch cross section of Reveille Range near Reveille.

1. Paleozoic (Cambrian) quartzite (1a) and limestone (1b). 4. Rhyolite sandstone.

2. Rhyolite.

3. Porphyr'y dikes.

5. Olivine-basalt

6. Valley wash (Pleistocene).

The more northerly locality was visited by the writer, and so far as a hasty examination conld determine, the lowest formation seems to be a hard white quartzite, surmounted by a dark-blue massive limestone, much altered and carrying only indeterminable fossils. As seen from Reveille, the mountain to the east seems to have at its base about 1,500 feet of quartzite, capped by 2,000 feet of limestone. The strike is north and south, the dip $W .15^{\circ}$ or $20^{\circ}$. If the section is actrally as supposed, the rocks can hardly be other than the Cambrian quartzite and limestone of the Eureka section. ${ }^{b}$

The strata are traversed by many porphyry dikes, probably eonnected with the rhyolitic outbursts. The rhyolite wraps around these limestone monntains in such a way as to show that they were ahready sharp peaks previons to the pouring out of the lava (fig. 21).

a U. S. Geog. Surv. W. One hundredth Mer., Vol. III, p. 37.

$b$ Ibid., p. 179, Mr. Gilbert cites Prof. J. J. Stevenson as having recognized Carboniferous rocks at Reveille. In view, however, of the confusion of Carboniferons and older rocks at this period (several other Cambrian areas having been referred to the Carboniferous) and in view of the fact that the lithology of the region is that typical of the Cambrian here, but probably not chareteristic of the Carboniferous, the writer has decided to retain in the mapping the Cambrian color. 
TERTIARY.

In the transverse cut across the northern end of the mountain range at Twin Springs the section consists of rolcanic roeks and water-laid tuffs and gravels derived from them. At the base of the section is altered biotite-rhyolite, and above comes about 600 feet of white rhyolitic sandstone. This is capped by 100 feet of rhyolitic tuffs and gravels, sumounted by about 100 feet of augite-olivine-basalt.

\section{IGNEOUS ROCKS.}

Is already stated, most of the range is made up of igneous roeks. Those which outerop most upon the surface appear to belong to the later, more basic lavas, of which the augite-olivine-basalt at 'Twin Springs is a member. This same basalt is fomd on the east of the higher mountains between Twin Springs and Reveille. Beneath this basic lava, however, the older biotite-rhyolite frequently comes to the surface and is distinguishable by its more rugged topography.

RELATITE AGE OF IGNEOUS ROCKS.

In the section at Twin Springs it is shown that the rhyolite is older than the basalt. Between Twin Springs and Reveille the intervening series of tuffs disappears with increasing clevation, and the basalt mantles around the base of eraggy rhyolite eminences in sueh a way as to show that they were already mountains before the basalt appeared. The disappearance of the intervening tuffs also suggests that the higher rhyolite peaks were mountains in the lakes in which the rhyolitic tuffs were laid down.

\section{ORE DEPOSITS.}

In the vieinity of Reveille are mines whieh formerly were very profitable, but which are now almost entirely deserted. The mines are situated in a patch of limestone and quartzite surounded by voleanic rocks, and the ores probably have genetic connection with the dikies which traverse the sedimentaries.

\section{BELTED RANGE.}

The Belted Range runs southward from the Reveille Range and forms, in its southern part, the eastern boundary of the Amargosa Desert. It is somewhat irregular, but has a general north-south trend. At its northern end it is separated from the Reveille Range by a slight interval of low, lava-covered country, while at its south end it is separated from the low mountains lying north of Pahrump Valley by a considerable intervening area of Pleistocene subaerial deposits. Its name has probably been given to it on account of the lorizontal banding visible for a long distance on its steep sides. 
SEDIMENTARY ROCKS.

CAMBRIAN.

The Belted Range was crossed by Mr. Gilbert during his reeonnaissance for the Wheeler survey. He notes that at White Bluff Spring and for several miles southward the range shows an axis of quartzite. $^{a}$ This he regards as the same formation as a similar quartzite recognized in the Timpahute Range, which is of Cambrian age.

The whole southern portion of the range, as seen from the south, is of stratified rocks, apparently chiefly limestones. It is probable that this portion of the range forms a part of the general CambrianSilurian area, which includes part of the northern end of the Spring Mountain Range, a large portion of Las Vegas Range, and at least the souther'n end of the Desert Range.

\section{IGNEOUS ROCKS.}

VOLCANIC ROCKS.

Mr. Gilbert ${ }^{b}$ found that near White Bluff Spring the principal mass of the range was of lavas, which nearly hid the Paleozoic axis. 'These lavas stretch northeastward and connect with those of the Reveille Range, and also extend westward, forming low mountains, which divide the Ralston Desert from the Amargosa Desert. In these mountains Fortymile Canyon is cut. They extend westward at least as far as Oasis Valley, which is the head of the Amargosa River; and they stretch northward over the whole of the Ralston Desert. ${ }^{c}$

\section{STRUCTURE.}

The probable structure of the Paleozoic southern portion of the range conld only be uncertainly made out from a distant view. In general, however, the rocks appear nearly horizontal, but they sometimes dip as much as $15^{\circ}$ at least. The general strike is parallel with the trend of the range.

\section{SPRING MOUNTAIN RANGE.}

The Spring Mountain Range is an exceedingly irregular-shaped group of mountains, lying southwest of Las Vegas Range, and separated from the Kingston Range, farther south, by the Pahrump Valley. The general trend of the range is northwest and sontheast, and its length in this direction is about 60 miles, and at its northern end, in the neighborhood of Charleston Peak, the total width is as much as 30 miles. This peak constitutes the highest portion of the range, being 10,874 feet above the sea, and is a conspicunous landmark. This range is divided into numerous ridges, which run in many dif- 
ferent direetions without much visible system. At at least two points at the northern base of the range there ocenr warm springs, namely, Indian spring aud the spring at White's ranch in Pahrump Valley. This is interesting, since the range contains few igneous rocks.

\section{SEDIMENTARY ROCKS.}

CAMBRIAN.

The north end of the range was traversed from Indian Spring southwest, by way of Hornet Spring, to White's ranch. At Indian Spring are limestones carrying Lower Carboniferous fossils, as determined by Dr. Girty. Following up the canyon which leads sonthward to Hornet spring a great thickness of limestones was passed through, all striking a little north of east, parallel in general with the north end of the range, and dipping northward at angles varying from $20^{\circ}$ to $65^{\circ}$. The limestone is all thin bedded. North of the summit of the pass comes in a thin bed of vitreous quartzite. At the summit is a thick white ritreous quartzite, often coarse and nearly conglomerate, beneath the limestone. Just south of the summit there is an east-west fault which cuts off the quartzite and again brings down the limestone into the section. In this limestone, at a point half a mile south of Hornet Spring, were found abundant fossils, which have been determined by Mr. Walcott to be Cambrian, probably Middle Cambrian. These fossils are in blue-gray semicrystalline limestone like that found above the quartzite north of the fault. It is probable, therefore, that some of the limestones exposed in aseending the eanyon north of the summit belong to the Cambrian, and that these pass upward into the Lower Carboniferous limestones at Indian Spring without any marked stratigraphie or lithologie break. The white quartzite at the summit is also probably Cambrian, since it underlies the limestones.

The thickness of the section shown north of the fault has been estimated at about 17,000 feet, of which an estimated thickness of 2,000 feet may be taken for the quartzite, leaving 15,000 feet for the limestones.

The Cambrian limestones near Hornet Spring are eontinuous only a short distance south, when they give place abruptly to Carboniferous limestones, the two being apparently separated by an east-rest fault, parallel with and only some 3 miles south of the one already mentioned. From this point to the southern end of the rauge it is probable that no Cambrian rocks are exposed, sinee Carboniferous fossils are found at many points.

Mr. R. B. Rowe's notes ${ }^{a}$ on the Cambrian may be summarized as follows :

About 7 miles south of Indian Spring, in a high range of hills, were found greenish-yellow shales, with thin, dark sandstone bands 
containing trilobite and linguloid shells. These were underlain by brownish massive lintestone, containing great numbers of trilobite remains. These Cambrian rocks appear to be directly overlain by dark-blue and gray, probably Carboniferons, limestones. The dip of the Cambrian rocks is due north, while that of the Carboniferous is to the sonth, suggesting an unconformity, although the two formations are divided by a covered wash $2 \frac{1}{2}$ miles wide. The Cambrian may be separated from the Carboniferous here by a fanlt or by an uneonformity.

In the whole Spring Mountain Range nothing was foum between the Cambrian and the Carboniferous suggesting a hiatus between the two periods.

On the sonthwest side of a traversed line from Indian Creek to Tule Springs (on the east side of Las Tegas Range), from a distance about 5 miles east of Indian Creek to abont 5 miles west of Corn Creek, the low hills near the ralley are Cambrian, and probably some on the north side of the valley also. About 6 or 7 miles southwest of Corn Creek, on the south side of the valley, there is apparently a fanlt, bringing the Cambrian against what is probably the Carboniferous (fig. 22). The Cambrian comprises a number of parallel ridges, with steep sonth-facing escarpments and with strata dipping north. Between the ridges is a covering of talus.

CARBONIFEROUS.

At Indian Spring Lower Carboniferous fossils were found in a black, fetid, semicrystalline limestone with brown sandy beds. They were determined by Dr. Girty as follows:

Ptilodictya sp.

Chonetes sp.

Productus cf. mesialis.

Orthothetes n. spl.

Dr. Girty remarks that this fanna can not with certainty be placed in the Lower Carboniferous, thongh it is probably of that age.

These rocks probably constitute a relatively narrow strip at the northern end of the range, and are snceeded on the sonth by older strata, as above described.

A few hundred yards south of the ranch at Indian Spring the following Carboniferons fossils were collected by Mr. F. B. Weeks, in $1900,{ }^{a}$ and were determined by Dr. Girty:

Zaphrentis sp.

Rlipidomella oweni.

Orthothetes inæqualis.

Productella concentrica?

Productus burlingtonensis.

Productus semireticulatus.
Productus cf. P. lævicosta. Spirifer keokntk.

Spirifer near neglectus.

Seminula humilis.

Camarotœchia sp. 
At the same locality Mr. R. B. Rowe ${ }^{a}$ noted and collected Lower Carboniferons fossils. The roek is massive and cherty hlue and gray limestone, with reddish and yellowish shaly and arenteeous layers. The seetion is as follows from the top downward:

\section{Section near Induan Springs.}

1. Massive cherty blue limestone, poor in fossils. Thickness unknown. Unconformity.

2 Red shales with thin bands of blue limestone and yellowish calcareous sandstone, about 300 feet. Lower Carboniferous fossils.

3. Massive blue limestone filled with crinoids and corals. Thickness unknown.

Fossils collected from the red shales underlying the upper blue limestore nuconformably were determined hy Dr. Girty to be Upper Carboniferous or Pennsylvanian, rather than Lower Carboniferons. 'Therefore the line between Upper and Lower Caroniferons lies between 2 and 3 .

About half a mile south of Indian Creek, fossils collected by Mr. Rowe from the rocks that apparently underlie the red beds from which the Upper (arboniferous fossils were taken, were found hy Dr. Girty to be Lower Carboniferons or Mississippian.

Abont 7 miles south of Inclian Creek, the fol'owing Carboniferous section was fomm by Mr. Rowe, orerlying the Cambrian. The section is giren from the top down.

\section{Seetion. a miles south of Indian Creek.}

1. Massive dark-blue limestons, weathering rongh, and containing white calcite spots.

2. Light-gray, massive. unfossiliferous limestone.

3. Massive dark-blue limestone, like No. 1.

About 3 or 4 miles south of IIornet Spring fossils are found in yellowweathering, blue, shaly, argillaceous, cherty limestone, which lies to the sonth of the thin-bedded Cambrian limestone, and is not readily separable from it in the field. In this yellowish, shaly limestone Fusulina cylindrica was found, and the horizon was therefore determined by Dr. Girty as Upper Canboniferous. Southward from here, as far as the point where the road enters the foothills, the rocks are all similar thin-bedded limestones.

To the east, Charleston Peak and the high ridge south of it are formed of massive limestone, which has all the appearance of belonging to the great Carboniferous series. Mr. Turner has informen the writer that Carboniferous fossils have actually been found on Charleston Peak by surveyors.

On the east side of Charleston Canyon Mr. Rowe ${ }^{b}$ noted that the range seemed to be made up of Carboniferous limestone. Well down in these strata some fossils were found, chiefly Fusutina. The rocks are light-gray arenaceous limestones, containing considerablo chert. 
Fossils collected by Mr. Rowe were identified by Dr. Girty as Pennsylvanian or Upper Carboniferous.

In the foothills of the range, just east of White's ranch, in Pahrump Valley, a collection of Lower Carboniferous fossils was obtained, as determined by Dr. Girty:

Zaphrentis sp.

Anlopora sp.

Fenestella sp.

Leptæna rhomboidalis.

Chonetes planumbonus?

Productus cf. mesialis.

Spirifer ef. grimesi.
Spiriferina sp.

Athyris lamellosa.

Seminula sp.

Rhynchonella sp.

Beyrichia sp.

Phillipsia sp.

About 7 miles north of the above locality the rocks are also Carboniferous, according to a note supplied by Mr. 'T'urner. Fossils were collected by Mr. F. C. Boyce from near Fremont $W$ ash, $7 \frac{1}{2}$ miles north-northeast of Manse post-office (White's ranch). On these Mr. Schnchert, of the United States National Musenm, reported:

The fossils $* * *$ are of Carboniferons age. There are two species of $Z a-$ phrentis, a Syringopora near mnltatimuata and a Spirifer fragment too small for determination.

South of Manse the range was not visited by the writer, but he observed that the same series of rocks extended east and south for a number of miles. Mr. Gilber, however, observed Carboniferous rocks east and south of here, at Cottonwood Spring ${ }^{a}$ and at Oleott Peak. ${ }^{b}$ At the first-named locality Mr. Gilbert made the following section:

\section{Section at Cottommod spring.}

1. Massive red and yellow sandstone:

Feet.

a. Yellow, 250 feet

b. Red, 150 feet

c. Yellow, 200 feet.

d. Rerl and shaly, 400 feet

2. Bedded, fine-grained to saccharoid limestone, gray and cream-colored: beds separated by shaly layers so as to weather in steps. [Plillipsia (?), Macrocheilus (non des.), Naticopsis, Avicnlopecten, Avicnla, Meehella, Myalina, Productus semireticulatus, Spirifer lineatus, Athyris subtilita, Symocladia].

3 . Massive gypsum. white and red, in lenticular masses . . . . _... _. . . . 0 to ro

4. Gray, massive, cherty limestone:

a. Limestone [Meeliella, Productus, Chatetes, Syringopora], 250 feet_-

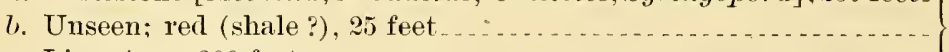

c. Limestone, 200 feet

5. Friable sandstone, in places shaly or marly; variegated with brilliant iron colors

Total

The fossils here show that the rocks of the section are Upper Carboniferous. At Olcott Peak the fossils, according to Mr. Gilbert, are Lower Carboniferous. 
At Mountain Spring, a point about 6 miles west of Cottonwood Spring, Mr. Gilbert ${ }^{a}$ notes that Mr. C. A. Ogden obtained a set of fossils of facies older than the Coal Measures. Among the forms are Phillipsia, Spirifer (two species of Devonian aspect), Rhynchonella, Hemipronites, Athyris (distinct from A. subtilita), Chonetes, Terebratula (?), Productus (like P. subaculeatus), and Fenestella. The horizon is referred to the Lower Carboniferous.

The following valuable observations on the Carboniferous of the sonthern portion of the Spring Mountain Range were made by Mr. R. B. Rowe in 1900-1901: ${ }^{b}$

Lourer Carboniferons.-About 6 miles south of Good Spring, Lower Carboniferons limestones are found, probably separated by an overthrust fault from Mesozoic strata. The Carboniferous is much altered, but in some of the layers good corals are found. The Mesozoic beds consist of rich shales and sandstones.

At Mountain Spring fossil-bearing Lower Carboniferous beds not more than 3,000 feet thick occur. Above these are Carboniferous red berls, at least 2,000 feet thick, which are overlain by Upper Carboniferous limestone, from 500 to 600 feet thick. Beneath the Lower Carboniferous is a light-gray arenaceous limestone. The line between this limestone and the overlying Carboniferous limestone is sharply drawn. ${ }^{c}$

Carboniferous red beds (Upper Carboniferous).-About one-half mile west of Monntain Spring, on the road to Mule Spring, is a dark fossiliferous limestone lying upon a light-colored, much-altered limestone. These limestones are probably Lower Carboniferous. In the valley west of Iountain spring they are overlain by a considerable thickness ( 2,000 feet?) of red Carboniferous shales and sandstones, which form a greater portion of the Mule Spring Monntains and are capped by the Upper Carboniferous fossil-bearing cherty limestones. On the east side of Mule Spring Mountain the red shales and sandstones are found at the base, capped by the Upper Carboniferous limestones.

For 8 or 10 miles north and northwest of Mule Spring the Upper Carboniferous is overlain by the fossiliferous Jurassic. ${ }^{d}$ There are no red beds or conglomerates between the two formations, although some of the topmost layers of the Carboniferous are conglomeratic. The thickness of the Upper Carboniferous limestone is about 500 feet. The thickness of the Upper Carboniferous red shales and sandstones exposed in this region must be two or three times as much.

Between Mule Spring and Mountain Spring red sandstone occurs, with a northerly strike and a dip $20^{\circ}$ west.

At Mountain Spring the Carboniferous red beds lying above the 
Lower Carboniferous are at least 2,000 feet thick, and are orerlain by 500 to 600 feet of Upper Carboniferous limestone.

On a divide along the road between Good Spring and Cottonwoor Spring, Carboniferous red beds immediately underlie the fossiliferous Jurassic, " as is the case also at Good Spring; but about 6 miles east of Cottonwood Spring the Jurassic ${ }^{a}$ lies directly upon the Upper Carboniferons limestone.

Sonth of Indiau Spring, at the northern end of the range, are red shales and sandstones underlying massive blue limestones unconformably. The shaly layers and the thin limestone bands in these red beds are fossiliferous. They were determined by Dr. Girty as Upper Carboniferous. The formation here has a thickness of about 300 feet. It overlies blue massive Lower Carboniferous limestone.

Upper Carboniferous limestome.-For 8 or 10 miles north and northwest of Mule Spring the folded Upper Carboniferous is overiain by fossiliferous Jurassic. " The Upper Carboniferous limestone is about 500 feet thick; the Upper Carboniferous red shales and sandstones about 2,000 feet thick. The Upper Carboniferous limestone may be divided about equally into (1) upper cherty massive limestone, containing abundant fossils; (2) lower light-gray, massive limestone, containing' a few fossils. 'The two portions are divided in some places by layers of red shales and samdstones, as, for example, at Cottonwood Spring. One-half mile west of Mule Spring Mr. Rowe collected fossils determined by Dr. Girty as Peunsylranian or Upper Carboniferous.

On the escarpment of the west side of the Mule Spring Mountain there is exposed the Upper Carboniferous limestone, underlain by the red shale formation.

At Mountain Spring, Carboniferous red beds are at least 2,000 feet thick. They overlie about 3,000 feet of Lower Carboniferous strata, and underlie Upper Carboniferous limestone from 500 to 600 feet thick. Beneath the Lower Carboniferous is a light-gray arenaceous limestoue, containing no discovered fossils.

At Cottonwood Spring fossils were collected from the Upper Carboniferous by Mr. Rowe, and were subsequently identified as such by Dr. Girty. ${ }^{b}$ Upper 'Carboniferous beds were followed 'some distance south of Cottonwood Spring; also east of Cottonwood Spring.

In the hills morth and northwest of Cottonwood Spring the Upper Carboniferous is overlain by conglomerate and strongly cross-bedded coarse sandstone, in beds 10 or 20 feet thick. Above these conglomerates are shales and gypsum beds, above which again are the fossiliferous arenaceous Jurassic ${ }^{c}$ limestonss.

a Mr. Rowe's field determination.

b See citation from Mr. Gilbert on Upper Carboniferous at Cottonwood Spring, above.

c Mr. Rowe's field determination. 
About 3 miles southeast of the summit, between Good Spring and Wilson's ranch, the Lower Carboniferons of the Bird spring Range lies against the Upper Carboniferous and Jurassic, ${ }^{a}$ being separated by a fault.

About 6 miles east of Cottonwood Spring, directly overlooking Las Vegas Talley, is an escarpment consisting of Upper Carboniferous beds. These are underlain by heary shales and brownish micaceous sandstone, much cross-bedded. At this point the red beds seen are not over 50 feet thick.

Between Good Spring and Cottonwood spring the Upper Carboniferous repeatedly occurs. North of Good Spring a low knoll of the Upper Carboniferous occurs west of the road, up to the Iesozoic cliff at the foot of Olcott Peak (Potosi Mountain). Near the summit both Carboniferous and Mesozoic rocks occur along the road. East and north of Cottonwood Spring are apparently Carboniferous rocks, while south and west are Mesozoic.

Abont 12 miles north of Good Spring, near the divide between Good Spring and Cottonwood Spring, is a small area of Upper Carboniferous, occupying a fault zone which separates the probably Mesozoic red sandstones and shales from the Lower Carboniferous limestones which make up Olcott Peak. ${ }^{b}$ On the east side of Olcott Peak, about 10 miles north of Good spring, fossils were collected by Mr. Rowe that were identified by Dr. Girty as Upper Carboniferous or Pennsylvanian.

About 3 miles northeast of Good Spring, in the Bird Spring Mountains, there was noted about 425 feet of gray, brownish, and pinkish arenaceous limestone. Fossils collected at three different horizons in the series by Mr. Rowe were determined by Dr. Girty to be Upper Carboniferous or Pennsylvanian.

At Good spring the following section was obtained, from the top down:

Section at Good Spring.

Feet.

Consolidated ancient talus 6-10

Arenaceons light-brown limestone, rather thin bedded

In part yellowish and reddish shales and sandstones, which make the same red terrane as shown at the eastern base of Olcott Peak .............. $; 60$

Heavy conglomerate. snbangular pebbles

Gray limestone with some red and pinkish arenaceons layers and cherty layers: the upper $\tilde{\pi} 0$ feet is conglomeratic and contains large quartzite bowlders: fossils abundant in the conglomerate, less so in the rest . . . . . -

Mr. Rowe regards the 50 feet of conglomerate underlying the red beds as a basal conglomerate, and the conglomerate at the top of the limestone beneath as an apical conglomerate. Fossils of the lower conglomerate collected by $\mathrm{Mr}$. Rowe are regarded by Dr. Girty as probably Permian, or uppermost Carboniferous. Fossils collected 
from the arenaceous limestone overlying the red beds are regarder by Dr. T. W. Stanton as not younger than 'Trias, and perhaps as old as the Permian.

Fossils collected from the Upper Carboniferous at Cottonwood Spring by Mr. Rowe are regarded as possibly Permian hy Dr. Girty.

East aud sontheast of Good spring, along the roat to Manvel, occurs the coutact of the Mesozoic and Carboniferous. On the east and north are Upper Carboniferous beds with fossils identical with those found at Good Spring. The red shales, sandstones, and conglomerates which lie between the Upper Carboniferous ard Jumssic at Good Spring and at Olcott Prak are wanting about 5 miles southeast of Good Spring, and the calcareons sandstones of the Jurassic lie directly npon the Carboniferous. The Upper Carboniferous also has lost at this point the conglomerate which lies at its top at Good Spring.

'The mountains near Good Spring are chiefly limestones, with considerabie sandstone mnderlying. Fossils collected hy Mr. Rowe from the lowest rocks exposed in the Bird Spring Range ${ }^{a}$ were irlentified by Dr. Girty as Pennsylvanian or Upper Carboniferous.

Correlation with Grand Canyon section.-In the Grand Canyon and Colorado Platean region the Carboniferous was studied in the course of the Wheeler survey by Messis. Gilbert and Marvine. It was divided into the Aubrey limestone, the Anbrey sandstones, and the Red Wall limestone. The Aubrey limestone has a maximm thickness of 820 feet, and contains fossils suggesting the Permo-Carboniferoms of the Mississippi Valley, and indicating the close of the Carboniferous age. The limestone is characterized by a great abundance of chert, which toward the top sometimes constitutes half the mass. Near the middle it is in some places interrupted by a bed of shale with gypsum.

The Aubrey sandstone has a thickness along the Grand Canyon of about 1,000 feet. A portion is massive and cross-bedded, another portion soft and gypsiferous. The sandstones contain no fossils, but an intercalated limestone bears Coal Measures shells.

The Red Wall limestone has a gray color on fresh fracture. It is heavy-hedded and massive. Near the top sandstone alternates with the limestone for from 200 to 500 feet. Through its lower half the limestone is interrupted by occasional shaly bands. The average total thickness is 2,500 feet. Fossils are abundant near the top, but in the lower portions are difticult to find. The lowest fossils were found a little below the middle of the series, and were doubtfully referred to the Lower Carboniferous. The fanna of the upper portion is rich, and, while different from that of the Aubrey limestone, is referable to the Coal Measures.

Ir. Gilbert ${ }^{b}$ was not able to exactly correlate the Colorado Plateau

a The southern prolongation of the Spring Mountain Range, lying east of Good Spring.

$\iota$ U. S. Geog. Surv. W. One Hundredth Mer, Vol. II1, pp. 177, 178, 179. 
and Grand Canyon Carboniferous with the Carboniferons series in the Spring Monntain Range. Nevertheless, the Carboniferous described by Mr: Rowe seems to bear a general resemblance to the Colorado Platean and Grand Canyon section. This correlation may be snggested:

Correlation of Spring Hombtain amd Graml Camyon sections.

Gilbert and Marvine, Grand Canyon section.

Aubrey limestone, maximum \&:0 feet, Upper

Carboniferous.
Aubrey sandstone, 1.000 feet, probably Upper Carboniferous.

Red Wall limestone, Upper and Lower Carboniferous, 2,500 feet.
Rowe, Spring Mountain section.

Upper Carboniferous limestone, 500-600 feet.

Carboniferous red sandstone, shale, and conglomerate, 1,000-2,000 feet, probably Upper Carboniferous.

Lower Carboniferous limestones, 3,000 feet.

MESOZOIC.

Eight or 10 miles north and northwest of Mule Spring the Upper Carboniferous is overlain by fossiliferous Jurassic. ${ }^{a}$ Among the fossils seen in the Jurassic Pentacrimus astericus ${ }^{a}$ is very abundant.

About $t$ miles west of Cottonwood Spring is a great escarpment, at least 2,000 feet high. It consists of two terranes, the lower being red shales and sandstones, making 11 about one-third of the height. Above this is a heavy yellow sandstone, containing occasional red lenses. These rocks are probably Mesozoic.

To the east and northeast of Cottonwood Spring the hills appear to be Mesozoic also.

In the hills north and northwest of Cottonwood Spring the Upper Carboniferous is overlain by beds of conglomerate and coarse, strongly eross-bedded sandstone. These beds are from 10 to 20 feet thick. Overlying these conglomerates are 100 feet or more of intercalated white gypsum beds and red shales, and above these lies the fossiliferous arenaceous limestone of the Jurassic. " Near the bottom of the fossiliferous beds is a stratum containing a multitude of Gryphoea."

About 10 miles north of Wilson's ranch, the Carboniferous limestone has been brought above massive red Mesozoic sandstone by a great overthrust fault. Between Wilson's ranch and Red Spring the Mesozoic is also found. About 8 or 10 miles north of WVilson's ranch the same overthrust fault as inentioned above was found. The massive Mesozoic sandstone here is colored pink, bright vermilion red, and white. It is strongly cross bedded everywhere.

Between Wilson's ranch and Cottonwood Spring the low hills show strata which contain .Jurassie fossils.

About three-quarters of a mile south of the summit, between Good Spring and Wilson's ranch, the Jurassic lies at the foot of a ridge mate up of Upper Carboniferous rocks, the Carboniferous being separated from the Mesozoic by a fault. 
At the foot of Olcott Peak there is a cliff composed of Mesozoic rocks. From here the Mesozoic turns east and crosses the road before the summit between Good Spring and Cottonwood Spring is reached. Near the summit Carboniferous and Mesozoic alternate along the road. From the summit to Cottonwood Spring, Mesozoic rocks oceur on both sides of the road. The rocks in the hills sonth and west of Cottonwood Spring are Mesozoic.

On the great fault line which separates the Mesozoic from the Carboniferous between Good Spring and Cottonwood Spring, the fossiliferous Jurassic apparently lies beneath the red and white sandstones which form the eliffs west of Wilson's ranch.

At Good spring the Mesozoic was found overlying the Carboniferous. The following is the section:

\section{Section of Mesozoic at Good Spring.}

1. Arenaceons limestone

2. At base yellowish and reddish sandstone abont 50 feet thick. Above this are layers of red and yellowish shale. This may be the same red terrane which shows at the eastern base of Olcott Peak ................ $r 60$

3. Heavy conglomerate

4. Gray limestone, with some layers of red or pinkish arenaceons limestone, and abundant layers of chert. The upper 50 feet contains numerons large quartzite bowlders

Fossils collected from No. 1 were described, after a preliminary examination by Mr. 'T. W. Stanton, as belonging to a horizon not yomnger than the Triassic, and possibly as old as the Permian. The fossils collected from No. 4 were judged to be questionably Permian by Dr. Girty.

East and southeast of Good Spring, along the road between Good spring and Manvel, the road runs along the contact of the Mesozoic and the Carboniferous. The red shales, sandstones, and conglomerates which lie between the Upper Carboniferous and the Jurassic at Good Spring and Olcott Peak are wanting about 4 or 5 miles sontheast of Good Spring, and the calcareous sandstones of the Jurassic lie directly upon the Carboniferous.

About 6 miles south of Good Spring the Lower Carboniferous seems to be overthrust upon the Jurassic.

\section{IGNEOUS ROCKS.}

At Good Spring, near the southern end of the range, Mr. Gilberta noted a flow of basalt. Other than this no igneous rock is known in the whole range. Mr. Rowe's notes record the following:

At the Keystone mine, at the southern end of the range, there is an acid porphyry dike rumning N. $17^{\circ} \mathrm{E}$. Along both sides of this, in a talcose material, gold is found. The dike dips from $35^{\circ}$ to $40^{\circ} \mathrm{W}$. 
East of Bird Spring Range, in the direction of the Colorado River, there appear to be extensive lava fields.

\section{STRUCTURE.}

The general observed strikes and dips of the strata in the Spring Mountain Range have been plotted by the writer from different points. The resnlts show more complex folding than in any of the mountain ranges to the north and east, and to this folding the irregular shape of the range is probably dne. In an east-west section the general structure of the range seems to be a broad syncline, with a number of minor folds, of little importance, and all part of the great fold. The axis of this syncline runs northeast and southwest, transverse to the general trend of the monntains and parallel to the axes of the folds in Las Vegas Range, already described, and well over to the western side of the monntains. Mr. Gilbert ${ }^{a}$ gives a section of the Carboniferous rocks at Cottonwood Spring, which shows the southeasterly side of this general syncline.

At a point on the eastern face of the range, due sonthwest from Corn Creek in Las Vegas Valley, a sharp, slight anticline, constituting a wrinkle in the genelal syncline and with a parallel axis, may be observed. On the other side of the range a similar anticline runs along the foothils northward from White's ranch for some distance. It afterwards appears to pass into and oceupy the narrow north-sonth valley between the northern end of the Spring Mountain Range and the low chusters of mountains immediately west.

In a north-south section, however, the structure of the Spring Valley Range appears to be anticlinal, the strike at both the north and south end being in general east and west, and the dip varying up to $65^{\circ} \mathrm{N}$. at the north end and up to about $20^{\circ} \mathrm{S}$. at the south end.

Taken altogether, therefore, the range exhibits a peculiar fold, antichinal in a north-south section, and showing a slightly complicated or wrinkled synclinorium in an east-west section. The portions of the center of the syncline that shonld lie flat dip north and south at each limb of the anticline.

Except at the northern end the rocks of the range are chiefly Carboniferous. At the northern end the Cambrian rocks are brought up, probably, by at least two heavy east-west faults. The northernmost of these faults observer lies north of Hornet Spring, and has apparently brought the Cambrian quartzite into juxtaposition with the Cambrian limestone, which stratigraphically overlies it. The throw of the fault must be at least 1,000 feet, and its course can be traced across the country by the break in the quartzite. The second fault lies 3 or 4 miles south of here, just south of Ilornet Spring. It is probably parallel to the first, although it can not be traced so easily, 
ut

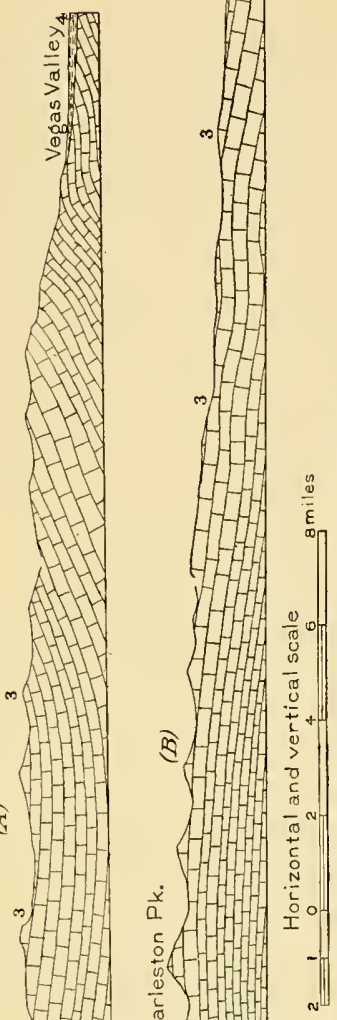$$
\text { क. }
$$$$
\text { 党 }
$$

since it separates one limestone body from another. But the limestone to the north is probably Middle Cambrian, while to the south it is Upper Carboniferous. A vertical displacement of several thousand feet is here evidenced, the downthrow being to the sonth, as is also the case with the first fault mentioned.

These two heavy faults have the same general direction as the heary fault deseribed in Las Vegas Range, and like it they have no primary effect on the topography, being marked by no scarps (fig. 2:2).

A third fault is suspected at the northern end of the range, separating the Carboniferous limestone from the supposedly Silurian limestone of the immediately adjacent Desert Range. If this fault exists, its downthrow is, like the others, to the south (fig. 22).

The following important observations on structure lave been taken directly from Mr. Rowe's notebooks, after the writing of the above:

Abont 10 miles west and northwest of Mule Spring, the Upper Carboniferous is thrown into a series of minor faults running in a nearly northwest direction. The piteh is very heary toward the south. These are probably the souther'n ends of the folds and uplifts which have brought up Charleston Peak. Together with the folding there was a great deal of minor faulting. A fault with a. throw of a few hundred feet is seen about one-half mile west of Mule Spring. On the east side of Mule Spring is a steep escarpment 
composed of Upper Carboniferous limestones overlying red shales. In this escarpment is shown a minor fault or a slight broken fold which appears to be recent and has directly displaced the surface.

On the west side of Mule Spring, at Mule Spring Mountain, the same formations are shown in a similar escarpment. Here the beds are thrown into minor folds and faults.

A great fault runs in a northerly to northwesterly direction directly through the center of the main Spring Mountain Range and through the minor ranges which are continous with it on the south (see map, Pl. I). This is shown 10 miles north of Wilson's ranch, where it runs nearly due north. It was also observed east of Mountain Spring (fig. 2t), and at the east base of Olcott Peak (fig. 23), and was traced past Good Spring to the southeast. At Good Spring its course is north and south.

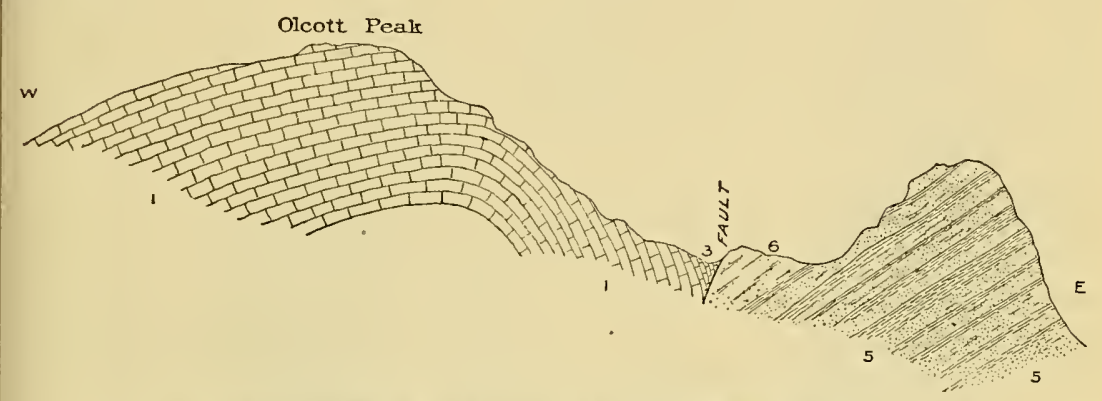

F1G. 23.--Section showing the great fault at Olcott Peak; after R. B. Rowe.

1. Lower Carboniferous limestones.

3. Upper Carboniferous limestones.
5. Mesozoic red beds.

6. Mesozoic heavy white sandstone.

Mountain Spring occupies the center of the important anticline which forms Olcott Peak or Potosi Mountain. East of Mountain Spring there is exposed the great fault. East of the fault is an erosion scarp (fig. 24 ).

Between Wilson's ranch and Red Spring, and about 10 miles north of Wilson's ranch, there is an overthrust fault, by which the Carboniferous limestone is thrust over the massive red Mesozoic sandstone. Three important faults are shown here-two running parallel and nearly north or west, the other (the great fault) rumning at right angles, or nearly north and south.

At Cottonwood Spring the apparent section is:

\section{Jurassic.}

Upper Carboniferous.

Red Beds.

Jurassic.

Upper Carboniferous.

This can only be explained by a fault. It is to be inferred that the fault is an overthrust. No direet evidence was seen.

- Bull. 208-03-12 
About 1 mile south of Cottonwood Spring the Carboniferous rocks strike $\mathrm{s} .63^{\circ} \mathrm{W}$., and $\operatorname{dip} 30^{\circ} \mathrm{NT}$.

About 6 miles east of Cottonwood Spring a great escarpment consists of Upper Carboniferous beds underlain by reddish shales and sandstones. Mr. Rowe's section indicates that the escarpment has been formed by the erosion of these softer beds.

In the valley east of the Cottonwood Spring escarpment there is probably a fault within the shale belt. This must be an overthrust fault along bedding planes, because everything eppears to be conformable. Red beds of the Carboniferous overthrust on the red bers of the Mesozoic make the fault difficult to see. Two or three days' search failed to reveal any direct indication (fig. 24).

There is some minor faulting shown in the Upper Carboniferous strata about Cottonwood Spring, and some minor folding in the Jurassic east of the springs.

On the divide between Good Spring and Cottonwood Spring there appears to be some very sharp folding or faulting at right angles to the general trend of the great faults, and at right angles to the great fault rumning on the east side of the Charleston Range.

The great fault lying on the east side of the Spring Mountain Range may be followed easily northward from Good Spring to the divide between Good Spring and Cottonwood Spring, 12 miles. On the east side of the fault is heavy-bedded red sandstone and red shales. On the west is Middle or Lower Carboniferous and Upper Carboniferons

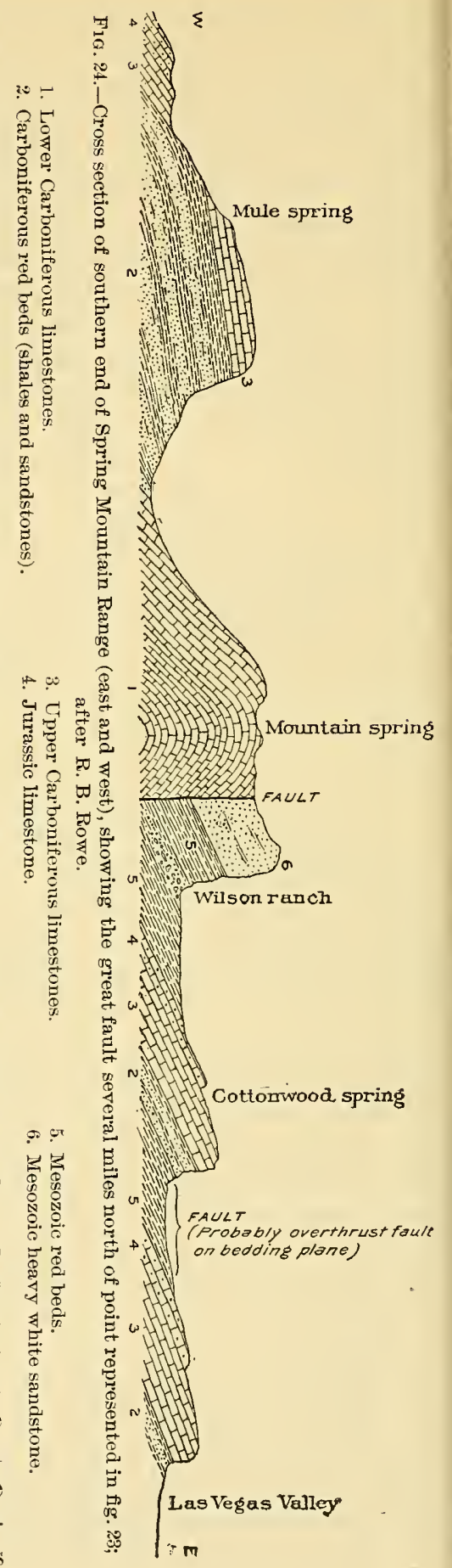


wedged in the fault by the chag (fig. 23). The section given by Mr. Rowe shows an anticline overthrown to the east and faulted. The fold is eut deeply by canyons. Along its axis the rocks are much erushed and broken, and much minor faulting is visible in places. This great fault line was followed north toward Wilson's ranch. It changes its course from about $15^{\circ}$ west of north, south of the summit, to $45^{\circ}$ west of north, north of the summit.

About is miles north of Good Spring the Carboniferous is folded into a sharp anticline and syncline.

The general structure of the Bird Spring Mountains seems to be antichinal, with a channel of erosion along the apex of the anticline. There is a fault along the east side of the range which brings the Lower Carboniferous against the red shales and sandstones of the Mesozoic. This fault runs northwest and

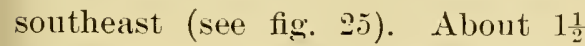
miles north of Bird Springs there is another fault, which crosses the first one at an angle and brings the Lower and Upper Carboniferous together.

About 6 miles south of Good Spring the Lower Carboniferous is overthrust upon the Jurassic. The rocks are very much disturbed along the fault line.

About three-quarters of a mile south of the summit, between Good Spring and Wilson's ranch, there is a fault which brings the Upper Carboniferous above the Jurassic. The fault has a nearly due northwest course. About 3 miles southeast of the summit there is another fault, also running due west, which

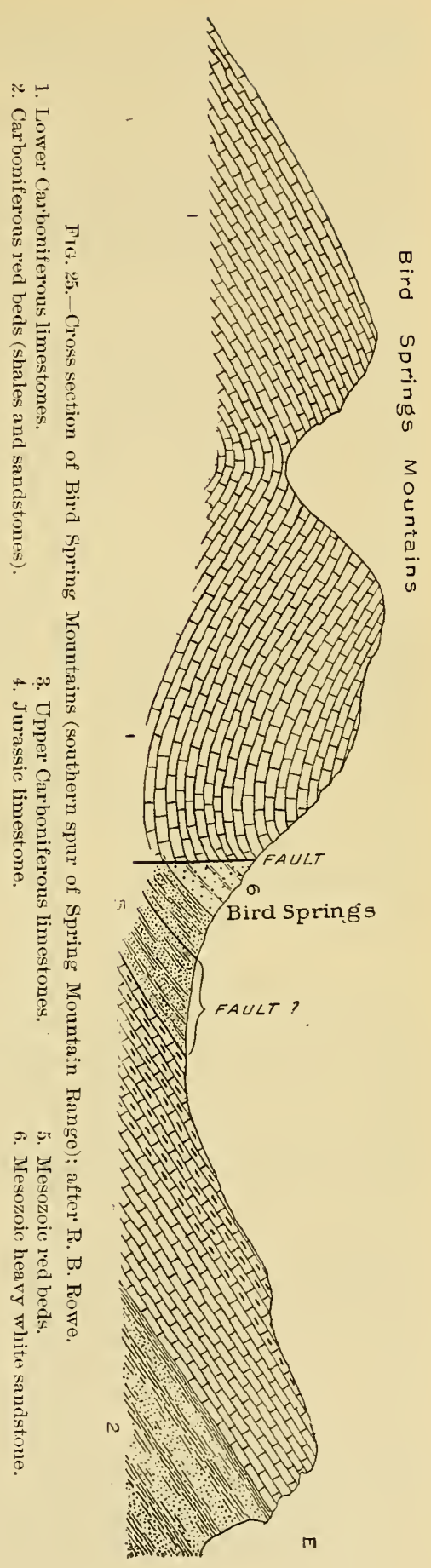


brings the Upper Carboniferous and Jurassie anainst the Lower Carboniferous. These fanlts are nearly normal to the direction of the main northwest-rumning faults. Minor folds shown at the summit seem to be at right angles, or nearly so, to the main folds ruming northwest.

About 6 or 7 miles west of Corn Creek, on the south side of the valley between Las Vegas Range and Spring Mountain Range, there is apparently a fault bringing the Cambrian against what is probably the Carboniferous." The Cambrian comprises a number of parallel ridges rumning east and west. The stratal dip north. Each of the ridges lias a steep escarpment facing south. Possibly there is a series of faults running parallel to the strike.

Just south of Indian Spring, at the northern end of the range, the Upper Carboniferous limestones show considerable minor faulting and folding. Except where locally folded, the dip of these rocks is generally southwest. About one-half mile sonth of the spring, yellowish arenaceous limestone is brought by a fault against clark-blue cherty limestone. The rocks are much broken, also, by minor fiults, which are hard to observe. In unconformity is shown in several places between the red shaly Carboniferous beds and the overlying Carboniferous limestone.

ORE DEPOSITS.

In the extrene southern part of the range is the old Potosi or Yellow Pine mining district. Here there are reins of argentiferous galena in the limestone. ${ }^{b}$

\section{AREA SOUTH OF SPRING MOUNTAIN.}

From Mr. Rowe's notebooks the following information is taken:

The range on the east side of State Line Pass, about 19 miles south of Good Spring, shows fossiliferous Carboniferous limestone on the west side. The limestone on the east side is probably also Carboniferous, but no fossils were found. The section made by Mr. Rowe seems to show faulting separating the two limestones. The beds dip throughout the whole section to the west.

Mr. 11. W. Thrner has kindly supplied the following note:

Locality on the boundary line between San bermardino County, Nev., and Lincoln Comnty, Nev., at State Line Pass, at about 6,000 feet elevation. Mr. Schuchert states that the collection which was mate by F. C. Boyce contains two species-a Chcetetes, which is usually identified as $C$. milleporaceus Edwards and Maime, and a Productus of the $P$. cora type. The horizon from which these fossils are derived is Carboniferous, and probably Upper Carboniferous. 
The north end of the MeCulloh Mountains is Carboniferous and seemed to be lithologically like the Carboniferous of the Bird Spring Mountains, consisting largely of light-gray arenaceons limestones.

\section{KAWICH RANGE.}

The Kawich Range forms the southern continuation of the IIot Creek Range, from which it is separated at its northern end only by a narrow transverse pass. From this point it extends due sonth about 60 miles, where its southern end runs out into the desert valley.

TOPOGRAPHY.

The range is high and is deeply eroded into bold, craggy mountains. On both sides the slope of the momntains is steep, especially on the west, where there are almost impassable cliffs. On the flanks of the range on both sides of the rngged backbone are smoother, mesa-like forms.

SEDLMENTARY ROCKS.

TERTIART.

The only stratified rocks known in the Kawich Range are the rinyolitic tuffs and sandstones which ocenr in the pass between the Kawich and the Hot Creek mountains and which also mantle around the northern base of the Kawich Range. These strata are evidenty the same as those described at Twin Springs, between the Pancake and the Reveille ranges. They are closely assoeiated with Tertiary rhyolites.

IGNEOUS ROCKS.

The igneons rocks constitute the whole of the main range, so far as noted. The rough, deeply eroded central mass of the mountains is composed of biotite-rhyolite similar to the basal rhyolite of the Reveille Range. In these rhyolites, as in those of the Reveille Range, there is a prononncer north-south jointing or sheeting which is not found in the younger lavas. The dissected mesas found in a narrow belt at the base of the monntains are composed chiefly of more basic lavas, with some acid lavas. From the western side of the range, near its northern end, specimens of tordrillite and biotite-andesite were collected. In the pass between the Kawich and the IIot Creek momtains decomposed andesite was found.

At the northern end of the Kawich Range the rhyolite abuts against the Paleozoic strata of the Hot Creek Range in such a way as to show that the mountains of the Hot Creek Range were already eroded out of the limestones before the rhyolites were extruded.

\section{RALSTON DESERT.}

East of the Sierra Nevada there is a belt of monntain ranges which have a Paleozoic or old granitic core, which have considerable heights, and whose general trend is northwest and southeast, parallel with the face of the Sierras. In this belt the rocks show frequently compressed or even overthrown folds, yet have experienced vastly less compres- 
sion than the intensely folded and sheared strata of the Sierra. East of these anxiliary ranges there is a belt which is eomparatively free from Paleozoic or old granitic ranges. It has been covered in many places by late Tertiary or Pleistocene lavas, so as partly to conceal the fact that it is a broad depression, but nevertheless this character is still traceable and even well marked on a topographic map. This great belt runs northwest and sontheast, parallel with the Sierra, and separates the region of northwest-trending ranges on the west from the north-sonth trending ranges on the east.

The Ralston Desert forms a portion of this. Northwest of the Ralston Desert the depression is continted by the lower end of Big Smoky Valley, by Sinkavata and Gabbs valleys, and farther north by the region of Carson and Pyramid lakes. Beyond this it appears to run up into Oregon.

On the south the Ralston Desert is separated from the Amargosa Desert by an irregular belt of late Tertiary voleanic mesas, throngh which Fortymile Canyon is ent. At the south end of the Amargosa Desert the open belt becomes narrow, but farther sonth passes into the Mohave Desert.

The Ralston Desert is bounded on the north and south by late Tertiary volcanic mesas, which, indeed, are found throughout its extent, so that these boundaries are rather arbitrarily taken. On the west the desert ends at the chiefly Paleozoic Silver Peak and Grapevine ranges, while to the east it is limited chiefly by the rugged Kawich Range, which appears to be prineipally rhyolite.

In general the desert consists of an irregular but nearly level sandy plain, broken by bunches of low mesas or slightly eroded voleanic mountains. Stonewall Mountain, which lies alout 30 miles east from Lida, is an exception to this topography, being a high, rugged group, reaching rrobably 9,000 feet in altitude, or 4,000 feet above the desert at its base. The northern side of this mountain is a steep cliff escarpment, probably 1,000 or 1,200 feet high, and is perhaps a simple faultsearp. (See Pl. VII, A.)

IGNEOUS ROCKS.

RHYOLITES.

Stonewall Monntain is entirely made up of rhyolite, and has been so deeply eroded that it can not be of very recent age. This rock is probably the same as the rugged rilyolite core of the Kawich Range. Northeast of Stonewall the low momntains in which Cactus Corral is situated are composed of rhyolite and tordrillite, also considerably eroded and probably belonging to the same period.

Most of the hills in the desert, however, show comparatively slight erosion. They represent thin flows, which have been very fluid and so have run comparatively long distances from the vent, at a very slight angle of descent. So the edges are thin-benched mesas, while the thicker, inner parts are irregular hills. While these mesas are 


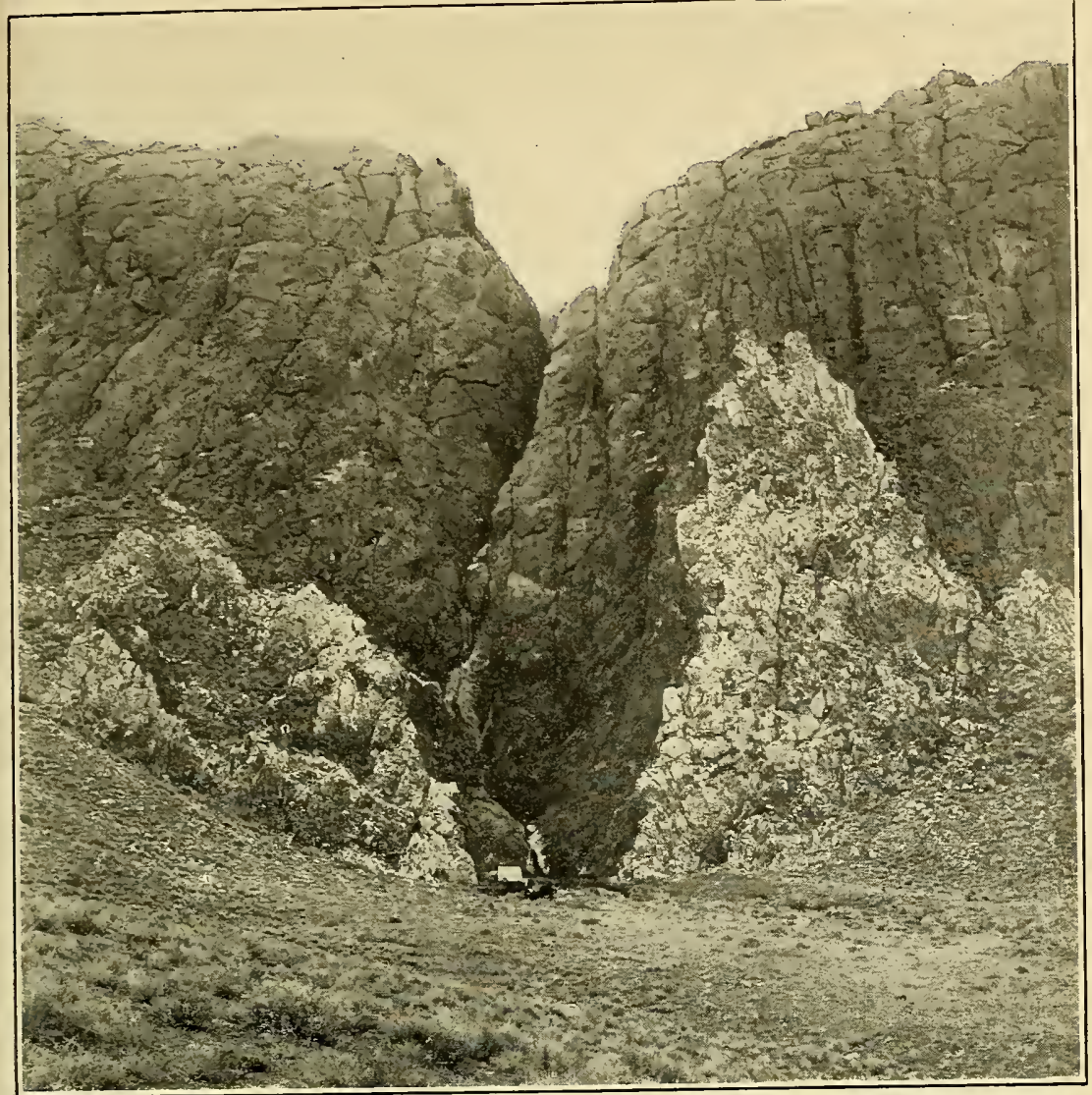

A. NORTH SCARP OF STONEWALL MOUNTAIN. RALSTON DESERT.

A fauit scarp (?).

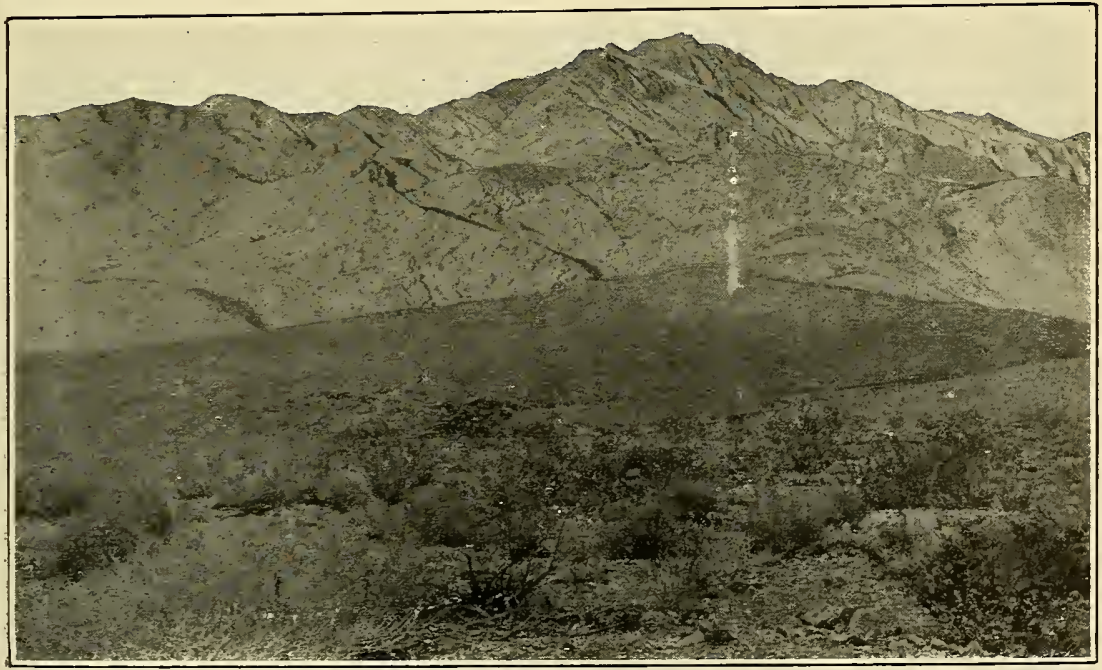

B. PYRAMID PEAK, GRAPEVINE RANGE, FROM THE HEAD OF FURNACE CREEK. 

evidently younger than the deeply eroded rugged rhyolite of Stonewall Mountain, yet they seem to be, in part at least, older than certain horizontally stratified rhyolitic clays which will presently be described as oceupying a large portion of the desert between the volcanic hills and underlying the Pleistocene sands. Within these stratified clays, and sometimes capping them, are also beds of rhyolite, very fine grained and often glassy. This is evidently the youngest of all the rhyolites, and we may infer that the rhyolitic eruptions lasted a long time, beginning with those of Stonewall Momtain and ending with the slaggy flows last mentioned.

BASALT.

The latest lava of the desert is a flow of slaggy olivine-basalt, lying at the base of Jackson Mountain, which is just east of Lidid. 'This is not only younger than the youngestrinyolite, but is apparently younger than the erosion of this and the underlying sediments to form the buttes, of which Jackson Mountain is one.

SEDIMENTARY ROCKS.

TERTIARY.

The main portion of Jackson Mountain consists of several lundred feet of hardened, horizontal sands and clays, containing irregular fragment.; of rhyolite. The base of the mountain is at an elevation of 5,100 feet, so that the uppermost sediments are at least 6,000 feet.

In the valley between Stonewall Springs and Cactus Corral there is also found green, hardened, rhyolite ash containing harder fragments. It is evenly and horizontally stratified and is overlain on the edges by the Pleistocene gulch dumps, or wash, which sometimes extend to the middle of the valley. The ash is eroded into hmmmocks.

This thick series of volcanic sands and clays was probably deposited in a body of standing water and represents a lake contemporary with the later rhyolitic eruption. As seen from the sediment: of Jackson Mountain, the lake must have been at least 1,000 feet deep on the desert.

PLEISTOCENE.

Along the slopes of all the momitains, especially of Stonewall Mromtain, are great wash slopes and gulch dumps fringing the scarp. This material, flowing down into the valley, overlies the Tertiary lake deposits. In the bottoms of the valleys are broad, bare mud hats or playas, evidently quite recent and contemporaneous with the gulch dumps. They seem to be simply sinks, where at intervals water collects and speedily evaporates. They do not represent the residum of evaporated Pleistocene lakes of which, moreover, there is no other evidence.

\section{LONE MOUNTAIN.}

For the following slight description of Lone Mountain the writer is indebted to Mr. Turner, since he himself saw the mountain only from a distance. The mountain really forms the northern end of the 
Montezuma Ridge of the Silver Peak Range, but on account of its exceptional height and prominence has been given a separate name.

IGNEOUS ROCKS.

The main part of Lone Momutain consists of eraggy, light-colored, massive granitic rock.

\section{SEDIMENTARY ROCKS.}

South of the granitic area the central portion cousists of Cambrian limestones 'To the east of this Cambrian belt is a helt of Silurian limestones, as determined by Mr. T'urner. Along the west flanks of the mountain the uptmrned heds of the Esmeralda formation (earrlier Tertiary) ocenr.

\section{SILVER PEAK RANGE.}

The Silver Peak Range is short and somewlat irregular in form. It lies immediately east of the northern end of the White Momnain Range, and like this range has a general northwest-sontheast trend. On the north the range is separated hy a low pass from the Monte Cristo Mountains, while on the south it rums into the northern end of the Grapevine and Panamint ranges. From near the southern end of the range a spur rums off to the north, forming the eastern bonndary of Clayton Valley, which lies between it and the main range.

The Silver Peak Range was studied by Mr. H. W. Turner during the summer of 1899 , and the mapping of the formations orer most of the range las been kindly fumished by him to the writer. Most of the following notes on the geology, designed to explain the map, are also due to him. Mr. F. 13. Weeks, of the Geological Survey, also spent some time during the same season in the Silver Peak region, chiefly for the purpose of collecting fossils, and the present writer passed through it on his way from Columbus to Lida.

The range is mostly marle $1 p$ of folded Paleozoie rocks, logether with intrusive granite and a large amount of volcanic material.

\section{SEDIMENTARY ROCKS.}

CAMBRIAN.

Fossils obtained by Mr. J. E. Clayton, as carly as 1866, at Silver Peak, and first regarded as Silurian or Devonian, were shown by Mr. Walcote to he Middle Cambrian. The studies of Mr. Turner have furnished many details concerning these Cambrian rocks, which oecupy considerable portions of the range. In some of the Canbrian limestones masses of the same corals oeeur as in the White Momntains to the west, so that Mr. Waleott regarded the two occurrences as essentially forming part of a single reef. ${ }^{b}$

The clief area of Cambrian is north of Silver Peak, where it is capped by voleanic rocks in many places. The buttes in Clayton 
Valley are also largely Cambrian. The section eonsists of comparatively massive limestones and quartzites.

Along the roat leading from Silver Peak by way of Barrel Springs to the sonthern end of the range at Lida, the rocks are chiefly Cambrian limestones. At Lida the writer collected fossils referred by Mr. Walcott to the Lower Cambrian.

\section{SILURIAN.}

Mr. Turner found orerlying the Cambrian limestones other limestones containing occasional graptolites, which he therefore refers to the Silurian. An arra of these Silurian rocks oceurs morth of Benderes Pass, while a helt of the same rocks ocenrs encircling a granitic area north of Palmetto. Silurian rocks are also found on the sonthwestern erlge of the branch momntain ridge above describerl, which may be called the "Montezuma Rirge" from the mining camp which is situaterl on it.

\section{EARLY TERTIARY.}

On the flanks of this range Mr. Turner has described sediments to which he gives the name of the Esmeralda formation." These deposits consist of sandstones, shales, volcanic tuffs, breceias, and conglomerates, and great thicknesses of lacnstral marls. Coal beds and plant remains ocenr; also fossil shells and fish bones. From this fossil evidence the age of the beds is broarly determined as late Eocene or early Miocene. The beds are nearly always folded, dipping from $10^{\circ}$ to $40^{\circ}$, but the entire thickness may be several thousand feet.

PLIOCENE.

A butte in Clayton Talley, northeast from Silver Peak, which is capped by olivine-basalt, is chiefty made up of horizontally stratified, partially consolidated, green volcanic ash and tuff, with pebbles of dark lava. The stratified beds are undonbtedly water-laid and are probably mucon formable with the folded Tertiary series just described, which occurs in patches all over the valley to the north of here. In general appearance the beds are like the Pliocene sediments which have such a broad distribution north of here, such, for example, as ocenr on the pass between the Candelaria Monntains and the Pilot Nountains. 'They are also similar to the latter oceurrenee in being capped by olivine-basalt and not being folded.

Going south from Silver Peak to Barrel Springs, the slopes of the mountains eonsist of rolled gravels whose pebbles are derived fiom most of the rocks around, including the lavas. These extend back eastward to the hills of the Montezuma Ridge, which are made up partly of volcanic rock. In the canyon below Barrel Springs the stratified gravels and sands, containing rhyolite pebbles, are found to lie against the eroded edge of a deposit of white volcanic ash and pumice apparently water-lairl, and this ash lies against the eroded 
edge of the slightly dipping Cambrian limestone. These gravels and sands seem to be the same as those in the butte described above.

In the outlying hills of the southern part of the range just east of Lida is a series of hardened, stratified, greenish clays and sands containing fragments of rhyolite. These clays have sometimes been eroded to form buttes, especially where capped hy lava. They are horizontally stratified and undisturbed, and are younger than the flow of olivine-basalt which sometimes mantles around the base of the buttes.

The deposits in these different localities may be provisionally correlated with the other sediments which have already been ascribed to the Pliocene-Pleistocene Shoshone Lake.

\section{IGNEOUS ROCKS.}

In the Silver Peak region the igneous rocks are ainumdant and varied.

GRANITES.

Granites occupy considerable areas, and field evidence shows that they are intrusive into the Paleozoic serliments, but not into the Tertiary rocks.

VOLCANIC ROCKS.

The volcanic history of the region is of considerable complexity and interest. Mr. Turner, who has made a study of this, has kindly supplied the writer with the information that the snccession of lavas in this district has been, in general, (1) rhyolites, (2) andesites, and (3) basalts.

\section{ORE DEPOSITS.}

At Silver Peak there are rich silver and gold mines. The Cambrian limestones are ent by pegmatitic granitic roek, which changes to pegmatite and quartz veins. The ores appear to be, partly at least, connected with these intrusions.

Numerous other localities are known where mineralization has occurred. At Barrel Springs the limestone is decomposed and stained along a vertical zone 10 yards wide with iron and copper. The honeycombed and cavernous appearance of the rocks shows that they liave been the channel for ascending springs, to which the mineralization is undoubtedly due.

At Lida the writer noticed an auriferous quartz vein 5 or 6 feet wide, occurring along the entire contact of a 20 -foot-wide nearly vertical dike of quartz-monzonite-porphyry which cuts the nearly horizontal Jower Cambrian limestones. This dike is evidently a phase of the general granitic intrusion and the quartz vein is an accompaniment. 


\section{GREAT BASIN RANGES OF CALIFORNIA, NORTII OF MOHAVE DESERT.}

\section{GRAPEVINE AND FUNERAL RANGES.}

The Grapevine and Funeral ranges are practically parts of a single monntain chain, which is the easternmost of the important chains belonging to the Sierra Nevada auxiliary belt. This chain faces the Amargosa and the Ralston deserts on the east, and has a northwestsontheast trend. The Grapevine Range is continued on the north by the Silver Peak Range, from which it is separated only by a comparatively narrow transverse valley.

That portion of the range which lies immediately north of Furnace Creek has been sometimes called the Amargosa Range; but in the present description all of the mountains from Furnace Creek northward will be inclnded moder the single term Grapevine Range, while those south of Furnace Creek will be described as the Funeral Mountains. To this southern portion of the range the name Amargosa has also been applied, and to certain parts of it the name Black Mountains; but these will here be omitted.

The Fnneral Monntains have a trend somewhat different from that of the Grapevine Range, being more nearly north and south. This change is accompanied by a similar change in the trend of the Panamint Range, which lies next west.

The Grapevine Range is not of great width, but is high and narrow, with wild scenery (Pl. VII, $B$ ). The Funeral Mountains are lower, and have a striking air of desolation, dne to the lack of vegetation and the dark, gloomy colors of the rocks. Both the Grapevine and Funeral ranges are cut by deep canyons which sometimes extend quite through the range, a phenomenon frequent in the Great Basin ranges.

At Furnace Creek the Grapevine Range fronts the Funeral Range with a south-facing scarp, so steep as to be almost inaccessible and about 4,000 or 5,000 feet in height. At the base of this scarp the drainage from it has cut a channel parallel with its, front, which forms that branch of Furnace Creek along which the road rmus across the mountains.

Both the Grapevine and the Funeral mountains present steep sides to Death Valley, which are bolder than the western side of the valley. 


\section{SEDIMENTARY ROCKS.}

Mr. George G. Daris has kindly sent the writer samples of the chief rocks at Gold Mountain, which appear to be a grayish, rather coarsegrained quartzite and a dark blue-gray slaty limestone of ancient appearance. These rocks may perhaps be Cambrian or Silurian.

At Bomblary Canyon Mr. Gilbert foumd limestones with imperfect fossils, which, with the stratigraphic data, serve to comnect the rocks with the Cambrian beds observed farther east. ${ }^{\prime}$

At the extreme southern end of the range, at Saratoga Springs, Mr. Gilbert, has noted the following section (from top to bottom):

Section at Saratoga Siprings.

1. Gray clay slate

2. Yellow slate, with beds of shaly limestone

600

3. Bedded and shaly limestone, banded in pmrple, yellow, and brown ..... 350

4. Crystalline limestone.

5. Dark-brown quartzose and argillaceons conglomerate ............. 140

6. Crystalline limestone . . . . . . . . . 85

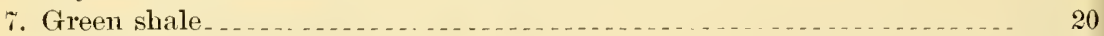

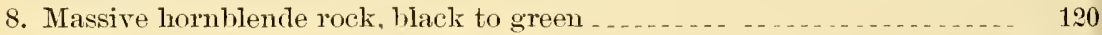

Total

Aceording to Mr. M. R. Campbell, ${ }^{c}$ the rocks composing the sonthern end of the Funeral Range at Saratoga Springs are limestone, shale, and quartzite, presumably of pre-Camlnian age and containing no fossils. They strike north and south, and dip about $50^{\circ} \mathrm{E}$. No Tertiary roeks were seen in the southern end of the range from Saratoga Springs, while strata resembling those exposed at Saratoga Springs conle be traced northward for several miles into the high summits.

\section{SILURIAN.}

At Furnace Creek Valley the writer olserved bowlders of pure white, vitreous quartzite extending down from Pyramid Peak, althongh the main mass of the mountain is limestone. This quartzite resembles the Silurian Eureka quartzite, so persistent in Nevada, and the relation of these beds to those orerlying, which are probably Deronian and Carboniferons, makes it probable that in Pyramid Peak and west of it the strata are largely Silurian. The writer has been informed by Mr. F. B. Weeks, of the Tnited States Geological Survey, that at Grapevine Peak limestones carrying Lower Silurian fossils (probably corresponding to the Pogonip formation of Eurrka) ocenr, and he regards these Silnrian rocks as probably continuons southward to Pyramicl Peak.

\section{DEVONIAN.}

In the monntains east of Pyramid Peak a great series of easterly dipping limestones are exposed, in which badly preserved fossils

"U. S. Geog. Surv. W. One Hundredth Mer., Vol. 1II, P]. 33, 169, 181.

bIbid., p. 1\%.

c Bull. U. S. Geological Survey No. 2(0, 1902, p. 14. 
resembling those found in the rocks of the ranges just east of here were observed. In the Kingston Range Devonian fossils were collected from similar rocks, and from the great thickness of the section exposed in the Graperine Range at this point it is likely that both the Devonian and the Carboniferous may be represented here.

TERTIARY.

In the eastern part of the range, where the road crosses from the Amargosa Valley into Furnace Creek, there is found a great anount of conglomerate, forming high hills. These conglomerates are very coarse and contain rounded pebbles and bowlders of all sizes, made up of reddish and white quartzite and black and gray limestones bearing the barly preserved Paleozoic fossils above mentioned. The conglomerate is as hard and firm as the rocks from which it is derived. It is water-laid and well stratified, and evidently a shore formation. The whole thickness exposed is estimated at $t, 000$ feet. It is sharply folded, together with the linestones from which it is derived, but it abuts abruptly against these limestones on the west.

The irregularity of the contact between conglomerate and limestone denotes a great erosion interval, yet no muconformity of attitude is apparent.

This conglomerate seems to fringe the north edge of the bold Paleozoic scarp of the Grapevine Mountains across the greater portion of the range. It is found at rarious points. A little west of Pyramid Peak conglomerate occurs, interbedded with and rumning laterally into a hard limestone, which has all the appearance of being calcareous tufa. A specimen examined microscopically bears out this iclea and shows that the roek is probably a chemical precipitate. It is like a rock found in crossing the Panamint Range from Death Valley to Windy Gap, and also like one from the Esmeralda formation, between the Candelaria Mountains and the Pilot Range.

Besides these rocks there occur, as parts of the same series, semiconsolidated gravels, with elays partially hardened to slaty shales, limy clays partially consolidated to argillaceous secondary limestones, and sands partially hardened to cherty and limy sandstones, all interbedded. All these, including the conglomerate and the limestone tufa, have a general light-yellow, often greenish color, characteristic of the series.

This sedimentary series makes up the greater portion of the Funeral Range. Along Furnace Creek Valley and on both sides of it the mountains consist chiefly of yellow-green strata capped by basalt. The lava seems to occur interbedded with the sedimentaries, as well as overlying them. The series is here consolidated into a hard clay rock, with occasional thin sandstone, and the general yellow-green color is changed in places to reddish, yellowish, and pinkish. The rocks are often gypsiferous and contain abundant grass remains, 
which are, however, indeterminable. From the yellow-green Tertiary series in the hills just east of the mouth of Furnace Creek there has been taken much borax, which occurs as borate of lime in beds in the strata. Superintendent Roach, of the borax works at Daggett, says that from one hill here-Nount Blanco-200 tons of borax a day conld be easily shipped.

On the eastern side of Death Valley, southward from Furnace Creek, the upturned yellow-green Tertiaries, with some few intercalated sheets of lava, constitute the mountains. Beneath some of these slieets the clays are baked to a red, natural brick. The lavas seem to occur ehiefly at the top of the yellow-green series, or at a still higher horizon, for the great mass of beds exposed in the lower portion of Furnace Creek contains no lava sheets; yet in these beds oceur occasionally lava bowlders and pebbles, so that we eonclude that the period was one of continual volcanic activity. From fragments of lava picked 1 p at the base of the mountains and from observations at a distance the lower lavas seem to be not so basic as the npper ones, which are chiefly olivine-basalt. A single specimen of biotite-andesite was all that was collected to represent these more siliceous voleanies.

Near the summit of the pass, just east of Furnace Creek, there come in above the yellow-green Tertiary series softer, dark-brown, honeycombed conglomerates, recalling the similar rocks of Meadow Valley Canyon. Thin sheets of basalt are interbedded with the conglomerates, but the great sheets lie on top. Patches of this same upper conglomerate series were elsewhere observed, and at one place its contact with the underlying yellow-green series appeared slightly discordant. The conglomerate contains pebbles and bowlders which are chiefly of lava and must have been derived from the sheets of basalt which were periodically poured out during the deposition of the beds.

A rough estimate of the thickness of this whole series of slightly consolidated beds and rolcanics puts it at not less than t,000 feet, and the nature of the sediments shows that they must have been deposited in standing water. The presence in some of the beds of gypsum, borax, and calcareous tufa shows that at some periods the waters in which the sediments were deposited were evaporated. They were, therefore, those of an inclosed lake, which was probably of great dimensions. It is likely that a large portion of the beds were deposited in fresh water at a period different from that in which the chemical preeipitates were laid down.

The borax in these beds is probably contemporaneous with the borax deposits in similar folded Tertiaries at Daggett and elsewhere in the Mojave Desert. Between these two localities, moreover, the strata, so far as known, appear to be roughly continuous. The strata of Mojave Desert are exposer on a grand seale at Cajon Pass, where they contan beds of black liguite. 
Northward from Furnace Creek, at Silver Peak, are found beds of the Esmeralda formation, which are entirely similar in nearly every respect to those at Furnace Creek. Moreover, the fossils fond in the Esmeralda beds indicate a nearly similar age to that indicated by fossils found in the Tertiary strata of the Mojave Desert, just west of Cajon Pass.

The upper part of the Furmace Creek beds is identical in appenrance with certain semi-indurated and slightly folded conglomerates and sandstones found in Meadow Valley Canyon, which have been referred to the Pliocene. ${ }^{a}$

PLEISTOCENE.

At the lower end of Furnace (reek the steeply dipping Upper Tertiary gravels are overlain directly and unconformably by horizontal gravels, which are partly consolidated and form bluffs 15 feet high.

These are the same gravels as were-noted on the eastern flanks of the Panamint Range, on the roal crossing to Windy Gap, the beds here having the same appearance and position. Their perfect horizontality indicates that they are perhaps the deposits of a postTertiary lake. This lake was a few hundred feet deep, as measured by the highest of these sediments.

It therefore appears probable that the Furnace Creek beds represent nearly the whole of the Tertiary period, from the Eocene through the Pliocene. It is possible also that the uppermost lavas belong in the Pleistocene, for they are fresh olivine-basalt, like that which is known to have been extruded throughout the Great Basin region during the Pleistocenc. $b$

A considerable portion of the area of greatest depression is vecupied by a great brown cesert. This has the appearance of a newly plowed field in color and form, and appears soft. On examination the surface is found to consist entirely of hard salt, rendered brown by a mixture of soil. This deposit is probably the result of the evaporation of the Pleistocene lake.

This lake was fed by the Amargosa River. The writer has been informed by those who are familiar with this region that occasionally the Amargosa River has been seen to be 200 feet wide at the southern end of Deatl Valley, although generally it is dry on the surface as far up as Ash Meadows. Along this dry course it flows underground, as is shown by the fact that water may. generally be found by digging a few feet below the surface. In Death Valley, also, water can be found in many places by digging, so the dregs of the lake may be said to still exist.

\footnotetext{
a See description of Meadow Valley Canyon, Meadow Valley Range, Mormon Range, and Virgin Range.

$b$ See J. E. Spurr, Succession and relation of lavas in the Great Basin region: Jour. Geol, Vol. VIII, p. 636.
} 


\section{IGNEOUS ROCKS.}

GRANULAR ROCKS.

Granitic rocks are said to ocenr at Gold Momntain, at the northern end of the range, where the gold ores are comnected with them. ${ }^{a}$

OLIVINE-BASALT AT FURNACE CREEK.

The Funcral Momntains are capped by heary flows of pyroxeneolivine-basalt, which seems to have been slightly involved in the latter part of the folding which affected the underlying Tertiaries. The rock is black and slaggy and is identical in appearance and composition with the Pleistocene olivine-basalts found frequently in Nevaclat.

Besides capping the Tertiary sediments, the basalt ocenrs in sheets which are, in part at least, certainly contemporaneous with the upper portion of the sediments, especially the conglomerate series. One basalt sheet was noter as metamorphosing the underlying conglomerates, but not the upper ones, and is therefore probably a flow and not an intruded sill. Moreover, the pebbles and bowlders in the upper conglomerate series are largely of the same basalt.

ANDESITE AT FURNACE CREEK.

Beneath the basalt sheets there is a rentain anomnt of less basic voleanic material in the beds. This was not carefully investigated, but a single specimen showed that biotite-andesite is represented.

VOLCANIUS NORTI ON FERNACE CREEK.

North of Furnace Creek the whole northeastern side of the Grajevine Range is overlapped by the sea of lava which occurs over most of the Ralston and Amargosa deserts, except where obscured by Tertiary or Pleistocene detrital accumulations. At the north end of the range these volcanics may connect with the voleanic area just north of Gold Mountain, which there extends to the western side of the range and is probably connected with the lavas at the northern end of the Panamint Range.

Mr. Gilbert notes that ihyolite occurs a few miles north of Boundary Canyon, flanking the range both on its eastern and its westerus side.

\section{STRUCTURE.}

Mr. Gilbert ${ }^{d}$ has drawn a section of the Graperine Range at Boundary Canyon. This section shows essentially a main anticlinal fold, slightly overthrown to the west, with an anxiliary, broad anticline

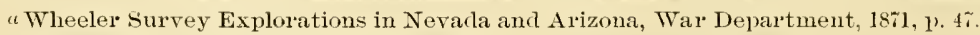
b.J. E. Spurr, Jour. Geol., Vol. VIII, p. 6336.

c. U. S. Geog. Surv. W. One Hundredth Mer., Vol. III, p. 33.

aIbid., p. 33. 
forming the slopes of the lange toward Death Valley, and a syncline between the two. These folds are much broken up ly faults, which, as Mr. Gilbert notes, are not only longitudinal, but transverse."

In crossing the mountains at the junction of the Grapevine and Funeral ranges, on the road leading to Furnare Creek, a good structure section was obtained. The south-facing scarp of the Grapevine Mountains shows a central chief anticline, with a rery great thickness of uniformly aasterly-alipping beds on the east limb. Wrest from this eentral anticline, whose axis is immediately west of Pyranid Peak, there is a second anticline, also with steep dips, in the mountains immediately above Death Talley, and between tha two anticlines is a slight syncline. On the south sicle of the pass, in the lower Funeral Mountains, it seemed to the witer that there is about the same structure, althomgh the dips appear to be decidedly less. No faults were noted in this section, though they rery likely exist.

The folds at Furnace Creek are probably continuous with those shown in Mr. Gilbert's section. Is the writer looked along the face of the Graperine Mountains, northward from Furmace Creek, he thonght to be able to trace the western anticline at loast as far as Boundary Camyon.

The Tertiary beds of the Funeral Momutains have therefore been folded together with the Paleozoics of the Grapevine Range. Yet the Paleozoic limestones appear to have in general steeper dips than the Tertiary strata. Nevertheless, the chief folding has come about since the deposition of the Tertiary. Not only the lower Tertiary beds, but also the upper conglomerates are folded, and even to a certain extent the interbedded and overlying olivine-basalt, which is of fresh appearance and may be in part as young as Pleistocene. Certainly, therefore, the upheaval of the Funeral Mountains and the present Grapevine Range has been rery recent indeed.

This is illustrated in the Funeral Range, which, as viewed by the writer, seemed to consist near its northern end of two anticlinal ridges with a synclinal valley between. This synclinal valley is oceupied by Furnace Creek, which follows the folding in all its bendings. The northwesterly course of the lower portion of Furnace Creek is caused by a corresponding bend in the synclinal trough. This deflection of the Furnace Creek syncline appears not to be continuous into the Paleozoic strata just north of here, and it is very likely due to the differential folling of the Tertiary strata against the hard Paleozoic buttress. In the summit of the pass above Furnace Creek, this folding against the Paleozoic cliff is well shown by a sharp local anticline in the Tertiary beds, the north limb of which dips from 20 degrees to to degrees toward the Paleozoic wall, which does not take part in the

a Mr. F. B. Weeks, of the U. S. Geological Survey, found in 1900 that at Graperine Peak the main range was decidedly synclinal in structure, the axis of the fold in general transverse to the trend of the range.

Bu1l. 208-0:3-13 
flexure. This fold, however, is of slight width, the dip reversing and flattening a hundred yalds south. (See Pl. VIII, A.)

\section{RÉSUMÉ.}

The succession of events in the Grapevine and Funeral ranges and in the region of Death Valley is, then, about as follows:

1. Deposition of a thick, conformable, Paleozoic series.

2. Elevation to a land mass, without marked folding.

3. The formation of sharp, lofty mountains, with deep valleys.

4. The deposition of the thick Tertiary series. This took place, in part at least, in a great lake or inland sea. In this lake were deposited near the shores conglomerates and breccias derived from the Paleozoic rocks; in the other portions were formed silts mixed occasionally with gravels. During the deposition of this series, especially the later portion, there was volcanic activity, and sheets of lava were poured into the lake, thus becoming intercalated with the sedimentary beds.

5. The lake, probably generally fresh, was at certain times reduced and evaporated, so that beds containing salt, borax, silica, and lime were ehemically precipitated and mingled with the detrital silts.

6. The volcanics changed to olivine-basalt. These lavas are assoriated with well-stratified sediments, such as might have been formed in a lake, but accurate data bearing on this point are lacking. The sediments may possibly be the result of stream action. They consist of brown and red conglomerates, which overlie the yellow-green lake beds, and are separated from them by some slight movement and perhaps an exosion gap.

7. Final flows of olivine-basalt.

8. Probably beginning before the deposition of the Tertiary, but not becoming very important until during and after the close of this period, came a disturbance, leading to rapid folding. The crust was bent, and perhaps broken, forming hills and valleys. Death Valley was created.

9. The mountains were eroded, producing minor irregular forms. The climate being slightly moister than now, a shallow lake a few luundred feet deep was formed in the bottom of Death Valley. 'This soon became charged with salt, borax, etc., derived chiefly from the leaching of the earlier lake beds, now become mountains. At this period the late Pleistocene shore gravels were formed.

10. The climate becoming drier, the lake evaporated, leaving a salt desert. Since that time there has been only a slight incision of the lake shore conglomerate by the rrainage from the mountains to the dry valley.

\section{AMARGOSA VALLEY.}

The Amargosa Valley lies between the Kingston and Funeral ranges. The following notes are from Mr. R. B. Rowe's notebooks, except where credited to Mr. Campbell. 


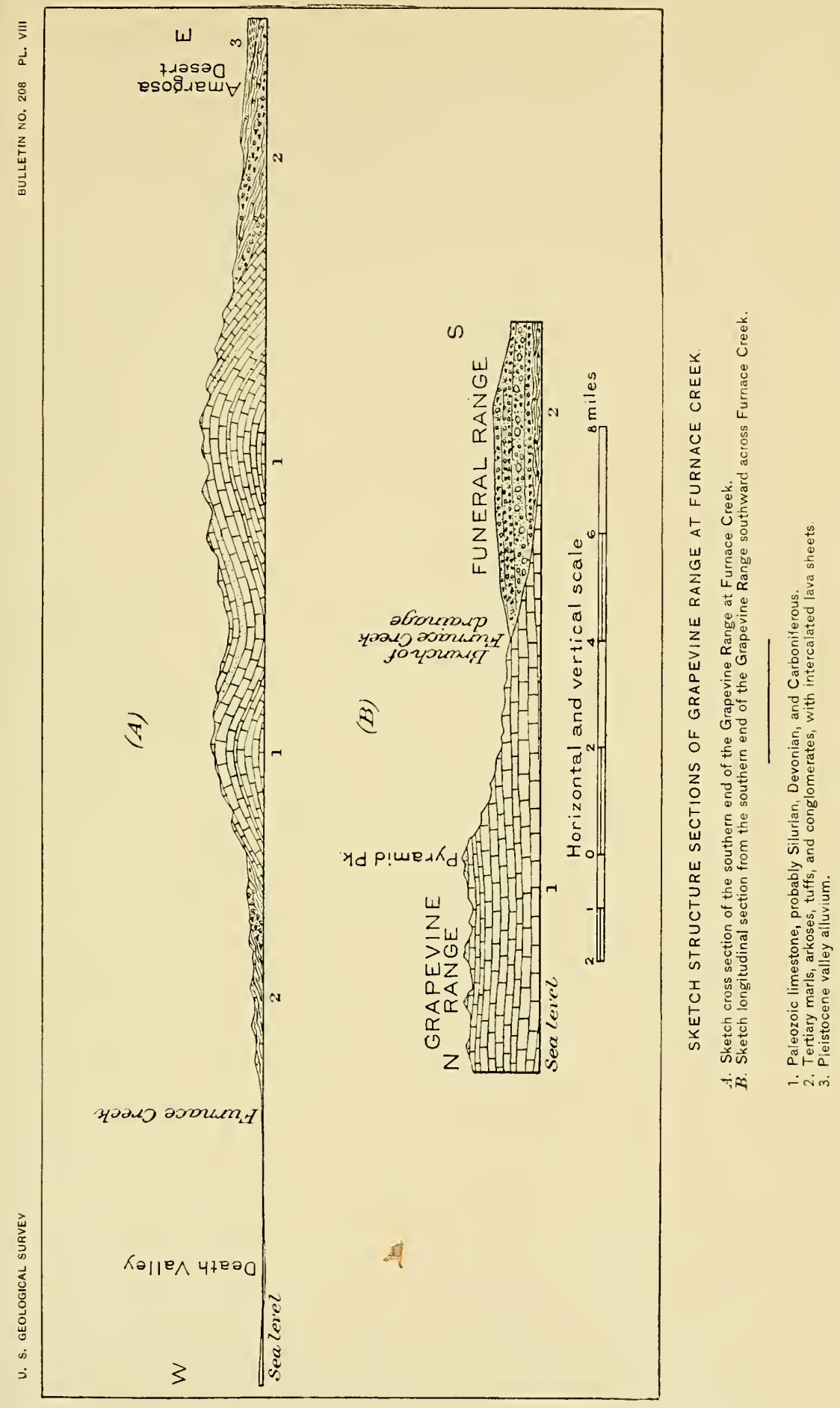



METAMORPHIC ROCKS.

Metamorphic rocks are exposed about a mile below the China ranch.

\section{SEDIMENTARY ROCKS}

TERTIARY.

Overlying the metamorphie rocks at the point mentioned above are Tertiary deposits. These Tertiary lakes were dry part of the time, or receded to a great extent and then swelled out again, for talus and lake deposits alteruate with each other in the lower Amargosa. At China raneh the Amargosa River euts through the Tertiary beds to a depth of 200 or 300 feet.

Mr. M. R. Campbell " has indicated on a map two areas of Tertiary lake beds near Amargosa Valley, one around Resting Springs and the other south of Ash Meadow.

\section{STRUCTURE.}

At China ranch the Tertiaries have been uplifted so that they dip at a high angle. The structure seems to be monoclinal. There is also some faulting in the Tertiary beds. Above China ranch the late talus deposits overlying the Tertiary are tilted up to a high angle, together with the Tertiary rocks.

For a distance of 3 miles, near China ranch, the Amargosa River has recently eut down about 20 feet into an old river deposit or wash. For a distance of about 1 mile it is beginning to ent down 4 or 5 feet farther. This is shown by waterfalls in the talus. This local downeutting seems to indicate recent movement.

Mr. M. R. Camplell ${ }^{b}$ states that the Tertiary beds in this valley bear evidence of considerable ermsial movement since their deposition. The eastem margin that lests against the foot of the limgston Range is 800 feet higher than the uppermost beds of the same series at the foot of Funeral Momntain. This indicates a drplession toward the west, in the direction of Death Valley. It seems possible that the change was due to thr sinking of Death Valley to its present position below sea level.

\section{KINGSTON RANGE.}

The Kingston Range lies between l'alumup Valley and the valley of Amargosa River. 'The California-Nevala line passes along its eastern base. 'The range has a northwest-sontheast trend and is 50 or 60 miles in length. At its northerne end it is separated by a short valley, ealled Stuart Valley, from the monntains which lie directly north of lahrump Valley, and which form an irlegular guomp affording a partial commection between the Spring Mountain Range and the Kingston Range. 'J'his gromp will be described logether with the Kingston hatngo. 
The Kingston Range generally has strep fronts, especially along the main eastern side, where it faces Pahrump Valley.

\section{SEDIMENTARY ROCKS}

CAMBRIAN.

Mr. R. B. Rowe, in 1500-1901, discovered and described Cambrian in the Kingston Range. The following information has been taken from his notebooks:

The greater part of the Kingston Range is made up of Cambrian strata. On the road from the post-office at Sandy to Kingston Peak there are sandstones and limestones, with metamorphosed graly sehists cut by dikes.

ringston Jountain consists of a central core of granite, which is topped on the north and northeast ly a fine-grained white quartzite with reddish bands. The succession at Kingston Peak, near Iforse Spring, from the bottom up, is as follows:

\section{Section at Kingston Peak.}

1. White, gray, or red quartzites.

2. Red, gray, and blue slates, and heavy beds of yuartzite.

3. Dark blue, much altered limestone.

4. Light gray, arenaceons limestone, intuch alteren, with crystallized calcite in its crevices and interspaces.

5. White and brownish quartzite, with conglomerate at the bottom. This sometimes alternates with the red, gray, and blue slates.

In some places the white quartzite at the base seems to run into a glay grneiss.

On the road between Manse and Resting Springs, 1 hrough the pass going to 'Tecopa, there is an excellent section of the mountains east of Resting Springs. The Cambrian seems to be repeated at this point, probably by a fault. At Resting Springs the thickness of the Cambrian, partly estimated and partly actually measured, is about 1,500 feet, and cau not be more than 2,000 fect. About 4 or 5 miles north of Resting Springs the Cambrian is capped by lava.

On the spur of the Kingston Range ending at Resting springs, at a locality about 2 miles north of the springs, the following section, from the bottom up, was observed:

\section{Section a miles north of Resting Springs.}

Heavy sandstone, probably all conglomeratic. Olserved pebhles were all well-rounded quartzite . . . . . . . . . . . . . . . . . . . . . . . . . . . 2,000

Generally gray shales, with bands of sandstone _...

Dark-blue limestone with shales and siliceous limestones, containing trilo-

bites and other Cambrian fossils

Quartzitic sandstones and shales.

About 7 miles east of Resting Springs the rocks in the range, which is part of the Kingston Range, are in part Lower Cambrian, and are a 
repetition of those exposed at Resting Springs. There is shown in these mountains about 4,000 feet of Lower Gambrian or earlier rocks. They consist chiefly of reddish and gray sandstone, some calcareous sandstones, and red and blue shales. Fossils were found within about 1,500 feet of the top, and none below that. Although a diligent seareh was makle, they were found only in one ledge, and seemerl to be poorly represented even there. About 800 feet below the top of the shale and sandstone formation, fossils are very abundant in some very thin sandstones. They consist mainly of trilobites, Hyolithes, and a brachiopod.

In the pass east of Resting springs, about, soo feet beneath the dark blue limestones, Cambrian fossils were collected. The section consists, from the bottom 11 , as follows:

\section{Section in pross erst of Resting Springs.}

1. Reddish sandstones and shales, blne shales, calcareons sandstones, ete. About 2,500 feet from the bottom Cambrian fossils are foum 1 , and they are also found 800 feet from the top

2. Massive lark-blue limestone, apparently containing no fossils

3. Light-gray limestone in more or less thin layers..

4. Shaly brown sandstone, with herls of limestone. Contains small trilobites and lingnloid shells. Probably Cambrian and possibly Lower Cambrian.

About \& miles east of Resting Springs is found No. 5 of the section, consisting of light-gray and dirk-hlue limestone, more or less massive; thickness, about 2,000 feet. There is an apparent unconformity between this limestone and the molereyng formations. Certain parts of the limestone are pouct rated hy what may he worm borings, now filled with raleite.

Ahout $9 \frac{1}{2}$ miles east of Twotremile spoings is blue and gray limestome. From loose blocks fomnd tribolites were collected, which did not alpear to Mr. Rowe to ho Ixwer Cambrian, hut to la somewhere between the 'Trenton and the Lower ('ambrian.

On thr roal from Resting siprings to Treopla the rooks are largely (omposert of gneiss rontaining pogmatite dikes. Tpon the gneiss lie shales, sambstomes, amd limestones of ('ambrian or pro-Cambrian age.

On the road from Pahrump ranch to Furnace ('reek, alome the northern alge of the Kingston liange, Mr. Rowe rollected Lower Cambrian fossils from the gray shaly sandstome.

MEVINIAN.

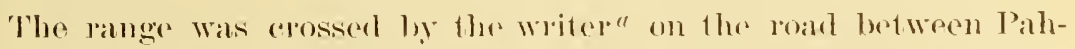
rump Valley and Furnaro (reck, in the Fumeral Ratege, this road leading past Sulphur Sprome and the heal of Stuat Valley.

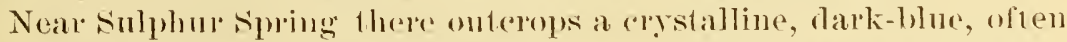
line-granod, siliceoms, foticl limostome. It is much altered by folding, 
but a small lot of fossils was obtained, which are regarded by Dr. Girty as Devonian. The species are as follows:
Zaphrentis sp.
Spirifer maia.
Orthis sp.
Chonetes deflectus:.
Spirifer maia (sinall variety)?.
Spirifer argentarins.

About 10 miles northwest of the fossil locality above mentioned oceurs a Tertiary conglomerate, containing pebbles of this limestone and quartzite, and from these pebbles another collection of fossils was made, which are determined by Dr. Girty to be Devonian:

Zaphrentis sp.

Crinoid stems.

Bryozoan fragments.

Spilifer pinyonensis.
Spirifer indeterminable.

Athyris? sp.

Atrypa missourensis.

Phæthonides sp.

MESOZO1C.

At the summit of the pass between Manse and Tecopa Mr. Rowe noted that the Paleozoic limestome is overlain by light-gray and chocolate sandstones, reddish and red sandstones, and dark-brown sandstones. Some of these are conglomeratic. Lithologically, this formation is like the Mesozoic of the Spring Mountain Range. These rocks seem to be unconformable with the underlying dark-blue Paleozoic limestone, the dip of the Paleozoic rocks being about 10 or 15 degrees greater. The supposedly Mesozoic rocks are about 1,000 feet thick, and are overlain to the south by a lava bed.

\section{TERTIARY.}

On the border of the Amargosa Desert, in the foothills of the north end of the Kingston Range, is found a coarse breccia or conglomerate, containing pebbles of brown on: blue fetid limestone and quartzite similar to that found in place in the Devonian series. These pebbles are angular, subangular, or rounded, and are of all sizes up to 2 feet in diameter. They are cemented by a coarse, red matrix, probably chiefly derived from the limestone. 'The stratification is hardly traceable, yet the deposit is probably water-laid. The general dip seems to be a few degrees northeast. About two miles west of here there occurs a thick deposit of medium coarse granitic arkose, which becomes finer grained and changes to greenish sand. Farther west this sand is seen to overlie a series of soft gray-green shales, sandstones, and granitic arkoses, moderately well hardened. The strike of this series is north and south and the dip $15^{\circ} \mathrm{E}$. The finer strata show oseillation ripple marks, snch as are formed in standing water, a few inches apart. Somewhat farther west, in the same series, was found a pure white, compact rock, which mieroseopie investigation shows to be a consolidated voleanic ash. It consists of many fragments of glass in a white opaque dust matrix. 'The ash underlies greenish, considerably indurated, sandstones, often oxidized to a red color.

This detrital series resembles the series of shales, tuffs, and sandstones exposed near Columbus and Silver Peak, which have been 
described by Mr. Turner under the name of the Esmeralda formation, and which carry early Tertiary fossils. The series is also probahly the same as that which makes up part of the Funeral Range, and extends over so wide a region sonth of here. Like all these beds, it is probably early Tertiary.

Mr. R. B. Rowe noted that about Resting Springs there are Tertiary deposits younger than the lavas of the same region.

IGNEOUS ROCKS.

The Tertiary arkoses described above seem to indicate the existence of granite somewhere in the vicinity. As viewed from Pahrump Valley, the southern portion of the Kingston Range in the neighborhood of Kingston Peak has a rugged, massive aspect which may denote the presence of grainite. Granite occurs not far southeast of here in the Clarks Peak Mountains, where it cuts the Paleozoic limestones.

At the extreme northern end of those low outlying mountains which lie to the north of the Pahrump Valley there appears to be, as seen from Pahrump Valley, a portion where the topography is low, smooth, and rounded, contrasting with the rugged, banded, stratified rocks farther south. This more monotonous region is probably volcanic.

Mr. Rowe noted the following concerning the igneous rocks subsequent to writing the above:

North of Resting Springs the Cambrian rocks are covered by lavas, which are separated from the underlying rocks by an erosion interval, but are folded to abont the same extent. These lavas dip at a high angle and are carved by erosion, like the sedimentary rocks. They do not appear to be as recent lavas as those in the Tertiary deposits. They occupy ancient erosion valleys in the Cambrian.

Between Resting Springs and Tecopa basalt is present in large quantities.

Gneisses in the pass between Sandy and Kingston Peak are cut by many dikes. Kingston Peak itself has a central core of probably pre-Cambrian or basal granite. The overlying quartzite is cut by dark-colored igneous rocks.

\section{STRUCTURE.}

According to Mr. R. B. Rowe, the general structure of the Kingston Range seems to be monoclinal, the dip being to the east. At Kingston Peak the Cambrian strata which overlie the central core of granite dip to the north and are folded.

A sketched cross section of the range north of the roarl between Sandy and Kingston Peak seems to indicate a slight synclinal strncture at this point. There is also a great deal of faulting here.

At Kingston Peak there is considerable faulting at right angles to the strike of the rocks, and some parallel to the strike. The pass east of Resting Springs seems to be along a transverse fault. 
Whout 8 miles eat of Resting Springs, and about 2 miles northeast of the pass, is a normal fault running 20 degrees west of north. This fanlt is also shown in the Resting Springs Valley. It brings up the Lower Cambrian shales and sandstones against the overlying limestone. The writer" has estimated the throw of the fault, from Mr. Rowe's description, to he about 8,000 feet.

There is an apparent unconformity at this place between the lower Cambran and the overlying limestone. The limestone strikes N. $28^{\circ}$ $\mathrm{W}$, and lips $4: 3^{\circ} \mathrm{NE}$.

About 6 miles north of Resting springs the lavas which lie upon the Cambrian are folded to the same extent as the Cambrian, both dipping northeast $52^{\circ}$. The Cambrian rocks must have been nearly level at the time of the eruption of the lava, although eroded to a considerable extent. The lava flowed over the eroded region, and was deposited in the valleys, against the edges of the strata. Then at a later period both were raised.

A section of a spur of the Kingston Mountains cast of Resting Springs shows a monochinal structure, the dips being uniformly east. The fault above mentioned runs nearly parallel to the range.

\section{OPAL OR CLARKS PEAK MOUNTAINS.}

This is a small group of momtains situated on the State line between Nevada and California, just south of the southem end of the Spring Mountain Range. Its chief eminence is Clarks Peak. The mountains are probably to be consiclered as an extension of the Kingston Range.

Mr. Gilbert ${ }^{b}$ notes that in these mominains near Iranpah the rocks are chiefly limestone, of which the age was not determined. .Judging from the fact that the whole sonthern part of the Spring Mountain Range is Carboniferous and that the Kingston Range is apparently also largely composed yf Carboniferous and Devonian, it is likely that the limestone of the :larks Peak Momutains belongs to much the same period.

Mr. Gilbert further otes that the central portion of these mountains is occupiod hy a belt of granite, cutting obliquely across the range, with limestone on both sides.

ORE DEPOSITS.

Rich silver ores ocent in these momtains, both in tho limestone and granite. Farther south large deposits of copper are reported.c

\section{PANAMINT RANGE.}

The Panamint Range is one of the most important of the ranges anxiliary to the Simra Nevada, which lie in the belt east of it and rum 
northwest and southeast parallel to its front. The range is albont 130 miles in length. At its northern end it mereses into lava flows which unite it with the northern end of the Graperine Range, while at its sonthern end it passes into low hills of Tertiary strata and associated lavas capped by later basic volcanies. It forms the sonthwestern barricr of Death Valley, which it fronts with a steep slope.

This range has been very little explored and not much is known concerning its goology. The detail of its mapping, therefore, and especially the differentiation of the Paleozoic which is known to exist in its central portion into the Cambrian and Silurian (as has been done on the aceomparying map, Pl. I), is very hypothetieal.

\section{SEDIMENTARY ROCKS.}

CAMBRIAN.

On the east front of the range, ahove the road from Furnace Creek in Death Valley to the erossing of the range at Windy Gap or Wingate, a large portion of the range consists of older stratified rocks, which seem, as viewed from a distance, to lie brneath uptnrned Tertiary sediments and associated voleanies, and are ent through by masses of intrusive granite. No close examination of these older roeks was made, but the drift shows them to be in part finely erystalline blue limestone, and in part quartzite, white, gray, or green, often considerably altered and often coarse grained. The amount of quartzite in the drift implies a considerable thickness of this rock and suggests that the strata are of Cambrian age, as this is the only dirision of the Paleozoic in this region which contains great amounts of quartzite.

From this neighborhood northward the Panamint Range is composed chiefly of old Paleozoic stratified rocks till near its northern end, as can be plainly seen from Death Valley. On the aceompanying map Cambrian rocks are represented as rinning along the crest of the range, the flanks being occupied by Sim rian.

The Panamint Range has been examined by Mr. Lí. Wr. Fairlanks ${ }^{\alpha}$ for some distance north of the region crossid by the writer. Mr. Fairbanks found on the western side of the range, north of Windy Gap as far as the Pinto Range (which is a sur of the Panamint Range rumning northwesterly from the Wild Rose inining (district), that a large portion of the rocks are mici-schists, quartzites, and marbles, which have been eut by intrusive granite. According to Mr. Fairbanks, the Pinto Range, as viewed from the Argus Range, appears also to be formed of bands of marble of various colors.

In the Graperine Range at Boundary Canyon Mr. Gilbert ${ }^{b}$ formd limestones containing imperfect Cambrian fossils. He notes that in that part of the Panamint Range which lies opposite Bonndary Canyon the rocks appear from a distant view to be similar. 
The strike of the folds is parallel with the trend of the range, so that unless disturbed by cross faulting the same general formations will be found for many miles. Therefore the Cambrian and Silurian have been represented on the map as extending northward until covered by volcanic flows at the northern end of the range.

SILURTAN AND CARBONIFEROUS.

Mr. F. B. Weeks, of the U. S. Geological Survey, visited various parts of the range in 1900. Near Panamint he found quartzite and limestones which he referred on stratigraphic grounds to the Cambrian. South of Shaw Peak (near the northern end of the range) he fonnd a considerable extent of Silurian rocks, with Lower Silurian (Pogonip) fossils, as subsequently determined by Mr."Ulrich. South of here the Silurian Pogonip formation was succeeded by the overlying Eureka quartzite, and still farther sonth were the Upper Silurian limestones, making the Silurian belt extend to Cottonwood Canyon. At the mouth of Cottonwood Canyon Mr. Weeks found Carboniferous fossils-Productus, erinoid stems, and a species of Seminula(?).

\section{EARLY TERTIARY.}

The eastern flanks of the range fronting Death Valley, as seen on the road between Furnace Creek and Windy Gap, are composed of uptnmed, yellow-green strata and associated voleanies lying upon the older rocks with no evident unconformity, and partaking of their folds. This belt of interbedded volcanies and sediments grows wider toward the south, and soon completely covers the Paleozoic area, which is wedged out between the younger series and the granite. The same series occurs along a great part of the road which crosses the range to Windy Gap. It consists of layers of calcareous tufa, evidently chemical deposits, with brown conglomerates containing lava bowlders, interstratified with and covered by lava, lava conglomerate, and lava breceia. 'The lava in these belts proved, in three different samples, to be biotite-hornblende-andesite.

This series of conglomerates, breccias, tuffs, chemical precipitates, and lavas is the same as that exposed on the opposite side of Death Valley, where it forms practically the whole mass of the Funeral Mountains. In the Funeral Mountains these rocks have been provisionally correlated with the Esmeralda formation in the Silver Peak Range, which are chiefly Eocene-Miocene.

LATE TERTIARY.

Mr. H. W. Fairbanks notes ${ }^{a}$ that on the northern slopes of the Panamint Range, overlooking Mesquite Valley, there are large areas of gravels, which are unconsolidated and reach an elevation of 6,000 feet, extending nearly to the summit of the range. These may be 
comparable to the younger semi-indurated conglomerate series in the Funeral Range, which is probably late Tertiary, ${ }^{a}$ or may be even Pleistocene.

\section{PLEISTOCENE.}

At the foot of the range, abore Death Valley, at its southern end, one finds, overlying unconformably the Tertiary deposits just described, bluffs of well-rolled pebbles and small bowlders with perfectly horizontal stratification, the strata making a continual angle with the slight dip of the surface to the east. 'This horizontality suggests that the deposit is a lake deposit, and connects it with similar conglomerates observed in a similar position in the lower part of Furnace Creek, in the Funeral Mountains. These conglomerates are also intimately connected with the gravels which occupy the bottom of Death Valley and with the salt desert which occurs between the two localities just described.

\section{IGNEOUS ROCKS.}

GRANITE.

In the southern portion of the range the core of the mountains for some distance is made up of a body of massive granite, which varies to granite-porphyry. This granite appears to be intrusive into the Paleozoic rocks, but not into the Tertiaries. Along the road which crosses the range east of Windy Gap the granite is hidden beneath these Tertiary rocks, but just south of the road another patch of granite is exposed around Granite Peak. The rock at Granite Peak was shown by microscopic examination to be a biotite-granite, verging toward alaskite, while farther north two samples of granite proved to be biotite-granite-porphyry.

Farther north, according to Mr. Frirbanks, ${ }^{b}$ the granite which cuts the ancient limestones and quartzites in the mining regions on the east side of Panamint Valley is a biotite-hormblende-granite with much quartz.

\section{VOLCANIC ROCKS.}

As already stated, volcanic rocks make up a considerable portion of the Tertiary formations. Thiree specimens of these rocks examined all proved to be biotite- or hornblende-andesite, but probably other' rocks occur in the series.

Overlying these folded lavas unconformably is a later flow of more basic rock, which covers a considerable area in the neighborhood of Browns Peak, just south of Windy Gap. Two specimens of this rock taken at different places proved to be in one case pyroxene-aleutite, and in the other bronzite-olivine-aleutite. ${ }^{c}$ Analysis shows them to be rather siliceous for the species. 
Mr. II. W. Fairbanks states ${ }^{a}$ that on the northern slopes of the Panamint Range, overlooking Mesquite Valley, there are seattered sheets of andesite and basalt.

Yet another series of volcanies is exposed in this region. It is that forming the greater part of the Slate Range, which lies immediately west of the sonthern end of the Panamint Range. The same rocks orenr in the region south of Browns Peak, in the Panamint Range, underlying the alentites. These older voleanics are comparatively light colored and weather reddish; they are, moreover, considerably sheared. Thin sections fail to exactly determine their nature, except that they are really lavas with glassy groundmass, and that they are largely feldspathic. From the shearing it is probable that these lavas are older than those in the folded Tertiary series.

Mr. Fairbanks ${ }^{b}$ found forming the highest portion of the Panamint Range for a number of miles east of Panamint a borly of ancient rhyolite, which he regards as one of the most ancient lavas observed in the region.

According to Mr. F. B. Weeks, of the United States Geological Survey, who has visited the northern end of the Panamint Range, the Paleozoic rocks are here covered by extensive flows of lava, which appear to be nearly continuous with the lava area at the extreme southwestern end of the Silver Peak Range.

\section{STRUCTURE.}

That portion of the Panamint Range between a point opposite Furnace Creek and W indy Gap appeared to the writer, studying it through field glasses, to be, in general, anticlinal. From Cottonwood Canyon northward to Shaw Peak, according to Mr. F. B. Weeks, ${ }^{c}$ the Paleozoic strata dip in general north of west.

The Paleozoic and Tertiary strata on the east side of the range, south of Enigrant Canyon, are apparently conformable and have the same folds. There is here a series of alternating anticlines and synelines, having trends dne north and south. Each of these folds may be traced contimuonsly for a number of miles. The axes of the folds, as sketched on the map, form a series of straight lines of moderate length, the more southern of which are continnally offset to the east from the more northern ones. The explanation of this phenomenon may be a series of east-west faults, which fault the folds systematically to the east on the south side.

Just north of the eastern part of the road which runs from Furnace Creek to Windy Gap, where this road enters the Panamint Range, the strike of the folds changes from north and south to northwest and southeast, and so continues to the extreme termination of the range, in the neighborhood of Owlshead Peak. In all this extreme southern portion there are no Paleozoics, but the Tertiary interbedded sedi- 
ments and lavas show the same system of folding as in the Paleozoics, although somewhat less pronounced.

The Pinto Mountains, a spur of the Panamint Range, lying northeast of the Wild Rose mining district, are stated by Mr. Fairbanks ${ }^{a}$ to have an apparent monoclinal structure, exposing an enormous thickness of strata whose truncated edges face Panamint Valley.

In the Panamint Range much of the deformation must be of conparatively recent date. WTe know that much of it ocenred since the deposition of the Tertiary beds and associated lavas, since these are involved with the Paleozoics in the npturning:

ORE DEPOSITS.

The following brief note on the ores of the Panamint Range is gleaned from the reports of Mr. H. W. Fairbanks. ${ }^{b}$ Near Postoffice Springs gold is found in quartz reins inclosed in limestone, which is folded to a syncline, with slates below and on both sides. The ore is high grade. In the neighborhood of the old town of Panamint are found silvel-bearing sulphides of copper, antimony, and arsenic, stromeyerite and tetrahedrite being the most common minerals. The gangue of the veins is quartz, and the veins are found in all the sedimentary formations of the district. North of here, in the Wild Rose district, a similar class of ores is found. Galena is seldom observed.

\section{LEACH POINT AND BURNT ROCK MOUNTAINS.}

The roughly defined east-west chain of low, iregular mountains which stretches eastward from the southern end of the Sierra Nevada at El Paso Peak to Pilot Knol is continned farther east in other low, irregular mountains, which just east of Pilot Knob have been called the Burnt Rock MLontains, and still farther, in the same direction, the Leach Point Mountains. On the north of these momntains the narrow Leach Point Valley separates them from the southern end of the Panamint Range. On the south lies the Mojare Desert.

\section{SEDIMENTARY ROCKS.}

\section{LIMIESTONE.}

About 8 miles northeast of Pilot Kinob there occurs, along the main traveled road, an ontlying spur from the low mountains, which is composed of very sandy blue limestone, amounting almost to it gray quartzite. This is interbedded with shaly and cherty thinbedded limestones. This rock strikes N. $190^{\circ}$ E. and dips E. $65^{\circ}$. It is slightly altered and sheared, and no fossils were found. It forms only a small patch, and is overlain by basalt. 
EOCENE.

The bulk of the mountains lying east of Pilot Kinob are flat topped and slightly pimnacled. They consist of light-colored stratified beds, with intercalated sheets of lava, the whole, in general, capped by black sheets of basalt. Mr. Gilbert ${ }^{a}$ has also noted these deposits in this range. They are probably the same as those exposed in the El Paso Mountains, where they contain Eocene fossils, and they are also the same as those which make up the Funeral Range and thus are widely distributed throughout this region.

\section{IGNEOUS ROCKS.}

GRANITE.

Along the western edge of these mountains granite is seen to be the basal rock. A specimen collected a few miles north of Pilot Knob appears to be a typical biotite-granite. The relation of this rock to the limestone above described is not known, but it is very likely intrusive in it, if we may judge from the similar occurrences in the Panamint and El Paso ranges and in other neighboring ranges.

VOLCANIC ROCKS.

Some miles north of Pilot Knob typical tordrillite ${ }^{b}$ was collected, apparently derived from one of the sheets intercalated in the lake beds.

Sheets of black basalt overlie the lake beds and constitute the latest voleanic rock of the region.

\section{STRUCTURE.}

The Tertiary beds and intercalated lava sheets seem to be, in general, nearly horizontal, but in one place at least-about 4 miles northeast of Pilot Knob-an anticlinal fold was observed, having a nearly north-south trend, with dips of from $10^{\circ}$ to $20^{\circ}$ on the limbs.

\section{WHITE MOUNTAIN RANGE.}

The important mountain lange immediately east of the Sierra has gone by the name of the White Mountains in its northern portion and the Inyo Range in its southern. Inasmuch as the two so-called ranges are not in any way disconnected, but form a complete whole, they will be here, for the sake of convenience, described together under the head of the White Mountain Range, as suggested by $\mathrm{Mr}$. Walcott. ${ }^{c}$ The range extends in a northwesterly and southeasterly direction, from the Candelaria Mountains on the north to the neighborhood of Oweus Lake on the south, passing at both ends into lower, irregular mountains of lava. No part of the range has been visited by the writer,

a U. S. Geog. Surv. W. One Hundredth Mer., Vol. III, p. 125.

$b$ Differing from $r$ hyolite in the lack of essential ferromagnesian constituents. See J. E. Spurr: Am. Geol., Vol. XXV, 1900, p. 230.

eAm. Jour. Sci., 3d series, Vol. XLIX, p. 169. 
and the following notes are entirely a compilation of observations, although now for the first time brought together. The observers include Messrs. Gilbert, Walcott, Turner, and Weeks, of the United States Geological Survey, and Goodyear, Gabb, and other geologists of the geological survey of California.

TOPOGRAPHY.

As a rule the topography of the White Momtains is characterized by great relief, with deep eanyons and high peaks. On the eastern side of the range there is an abrupt scarp for many miles, while the western slope, although generally steep, is on the average considerably gentler than the eastern. White Monntain Peak, which is at the northern end of the range, is of granite, and is a conspicuous landmark for many miles. It stands exactly on the boundary between Nevada and California.

\section{SEDIMENTARY ROCKS.}

CAMBRIAN.

Near the central portion of the range, or at the southern end of the White Mountains proper, Mr. Gilberta early observed a series of quartzites and schists with a little limestone. The age of this series he did not determine. Later $\mathrm{Mr}$. Walcott investigated it and found it to be Lower Cambrian. Mr. Walcott's chief studies were on the western side of the range. In several canyons to the east of Big Pine, namely, Wancobi, Black, and Silver canyons, Mr. Walcott ${ }^{b}$ found the following section:

Section east of Big Pine.

Feet.

200

4. Upper arenaceous beds

1,000

3. Alternating limestones and shales

2,000

2. Siliceous slates and quartzites

1,700

Total

4,900

No fossils were found in the lower limestone, but in the lower siliceous series are annelid trails and in places the heads of Olenellus, while in the upper limestone are great quantities of Cambrian corals, of the same types as occur in the Silver Peak Range to the east. Mr. Walcott notes that this is the oldest Cambrian fauna known in the western portion of the United States.

Northward from this locality Mr. Walcott found Cambrian rocks along the western face of the range, nearly to its northern end.

On the eastern side of the range he found many of the low mountains lying northeast of Saliuas Valley ${ }^{c}$ to be Cambrian, and also a 
great part of the main White Mountain Range bordering the same valley on the west. At the latter locality Cambrian rocks are cut by great masses of intrusive granite. At the northern end of the range Cambrian rocks occur in considerable quantities on the eastern side, alternating with areas of granite which are intrusive into them.

The rocks have here suffered cousiderable contact metamorphism by the granite, the limestomes being sometimes changed to clolomitic marbles.

SILURIAN.

Mr. Walcott" discovered a patch of rocks bearing Silurian ('Trenton) fossils on the eastern side of the range, southeast from Big Pine, along the road leading from Waucobi Canyon.

Mr. F. B. Woeks found in 1900, near the head of Mazurka Canyou, rolled remains of crinoids and fragments of bryozoa which indicate that the rocks at this place are not older than Middle Ordovician, and may be somewhat younger.

At the sonthern end of the range, in the vicinity of Cerro Gordo, Dr. O. Loew reports that the rocks are largely Silurian limestones containing great numbers of fossils, whose genera and species, however, he does not reeord. These rocks, he notes, are cut into by intrusive masses of granitic rocks.

\section{CARBONIFEROUS.}

Mr. Walcott' records that Mr. Fairbanks, of the California Mining Burean, discovered the characteristic Coal Measures fossil, Fusulina cylindrica, in the southern end of the range east of Keeler.

Also at the southern end of the range, just below the summit of Cerro Gordo Peak the following Carboniferous fossils were found by Mr. Weeks in 1900, and were determined by Dr. Girty:

Rhipidomella? sp.

Amplexus westi?

Productus fragments.

Marginifera splendens ?

TRIASSIC:

Just cast of Camp Independence Dr. Horn, of the California geological survey, discovered a fossil in a series of slates with intercalated limestone beds, which was considered by Mr. Gabb to be Triassie.

According to Professor Whitney, these same slates extend northward from bend City (just east of Camp Independence) for 25 miles. Yet this general region is delineated on the map aecompanying this

\footnotetext{
"Personal communication to the writer by Mr. Turner and Mr. Weeks. $\checkmark$ Personal communication to the writer.

c Ann. Rept. U. S. Geol. Surr. W. One Hundred th Mer., 1866, p. 63.

"Am. Jour. Sci.. 3d series, Vol. XLIX, 1895, p. 144.

eGeol. Survey California, Vol. I, 1865, p. 459.
} 
bulletin as granite, following the preliminary geologieal maps of the State of California, published in 1891 by the State Mining Bureau.

South of the locality above mentioned, near the crest of the range, halfway between Independence and Owens Lake, Mr. Walcott ${ }^{\text {}}$ found a single block containing Triassic fossils.

Mr. Turner ${ }^{a}$ traced the Triassic rocks as a continuous belt between the two localities above mentioned and also some distance farther south along the western flanks of the range. Mr. Turner states that the roeks consist essentially of Triassic lavas with interbedded tuffs. The same rocks oceur on the western side of Owens Valley, northwest of Owens Lake, on the flanks of the Sierras, and here also are of the same character.

From the lithology of the Triassic rocks above mentioned a probable correlation is established with the Koipato group of the fortieth parallel Triassic, as defined by King.

PLIOCENE.

Just east of Big Pine Mr. Walcott ${ }^{b}$ has described a considerable area covered by consolidated stratified deposits, which he regards as lake beds. The strata consist of fine calcareous, arenaceous, and argillaceous sands with layers of fine conglomerate, the whole being covered by angular débris washed down from the mountain since the deposition of the stratified material. The deposits are coarser near the mountains and finer as the distance increases. Some of the white beds are made up almost entirely of fresh-water shells, concerning which Dr. Dall says: "Any of them may be recent or Plioeene. My impression from the mass is that they are Pleistocene." Mr. Walcott ${ }^{c}$ found these beds reaching from the bottom of the valley up to a height of 3,000 feet above the valley, or to an actual height above sea level of about 7,000 feet. As an explanation for the great height at which these deposits are found, Mr. Walcott mentions two main hypotheses-first, that a lake 3,000 feet deep existed over the site of the present Owens Lake, and, second, that the Inyo or White Mountain Range has been elevated since the deposition of the lake beds, earrying up these beds with it. He inclines to the view that the latter is the correct hypothesis, on account of the steep easterly scarp of the range, which might be taken as a fault searp, and from other considerations.

The character of these beds, as described by Mr. Walcott, and their nearly horizontal attitude are identical with those of deposits of the late Pliocene lake which has already been deseribed by the writer as observed by him in numerous localities in Nevada, but chiefly in the region between Lake Mono and Carson. All these beds he has considered as the deposits of a late Pliocene lake-the Lake Shoshone of

$a$ Personal communication to the writer.

b Jour. Geol., Vol. V, p. 340.

e 1bid., p. 345.

Bull. $208-03-14$ 
King. ${ }^{a}$ In the region just north of Lake Mono he found the highest deposits of this lake at an altitude of 7,100 feet, and came to the conclusion that the uppermost deposits of the ancient Lake Mono formed part of the deposits of the same great water body. When the great lake stood at this altitude it must have been connected by numerous straits with the valley of the present Owens River, which formed an arm of the same lake. The uppermost limit of the lake beds noted by Mr. Walcott coincides almost exactly with the uppermost limit in the vicinity of Lake Moro and to the north of it. It is therefore likely that the deposits on the slopes of the White Mountain Range are to be correlated with these other deposits. The age indicated by the fossils found by Mr. Walcott also coincides with the other determinations made in other localities, all combining to indicate a period between late Pliocene and early Pleistocene.

If this is the case, no local elevation of the White Mountains can be inferred from the position of the lake beds at the comparatively great altitude where they are found, since the atitude is similar over the whole region. As was inferred by the writer with reference to the region around Lake Mono, there appears to have been a general uplift of mountain and valley throughout this whole region, lifting the deposits of the Pliocene lake about 1,000 feet higher than farther north.

South of Owens Lake Mr. Turner found ${ }^{b}$ well-stratified sands, gravels, and tuffs, occupying a large portion of the valley beneath the overlying Pleistocene accumulations, and having a slight dip westward. These may belong to the same series as above described. The same beds are mentioned by $\mathrm{Mr}$. Fairbanks, ${ }^{c}$ who notes that at Owens Lake they reach an elevation of at least 1,500 feet above the lake surface. Mr. Fairbanks regards these beds as formed under water. ${ }^{d}$

\section{IGNEOUS ROCKS.}

GRANITIC ROCKS.

Mr. Gilbert ${ }^{e}$ noted that the eastern ridge of the White Mountains, east of Deep Springs Valley, is composed of granite. The mapof the California State Mining Burcal ${ }^{f}$ shows a number of other granite areas. On this map the whole northern end of the range in the vicinity of White Mountain Peak is shown to be of granite, and also most of the range from Loehr Peak souchward to Deep Springs Valley. Farther south, a considerable area of granitic rocks is shown south of

a See pp. 11\%, 119, 1\%3.

b Personal communication.

c Am. Geol., Vol. XVII, p. 69.

a Mr. M. R. Campbell's later notes on these gravels (Bull. U. S. Geol. Survey No. 200, p. 20) show that they are gently folded lake sediments containing much volcanic tnff. They are very likely pre-Pliocene (Eocene or Miocene), like the lake beds in Funeral Range.

eU.S. Geog. Surv. W. One Hundredth Mer., Vol. III, p. 315.

$f$ Preliminary mineralogical and geological map of the State of California, 1891. 
Wancobi Peak, ${ }^{a}$ while a small area is shown southwest of Salinas Valley, also in the center of the range. In the low monntains lying northeast of Salinas Valley two considerable areas are shown.

From personal communications of Messrs. Waleott, Turner, and Weeks, further information on the extent of the granite has been obtained. The two northern granite areas represented as separate on the above-eited map appear to be continuous between Loehr Peak and White Momtain Peak. On the eastern side of the northern end of the range a great deal of granitic rock is found, entting the Cambrian sediments. Farther sonth, the granite area sonth of Waucobi Peak extends sontheastward in a continuous belt to the area sonthwest of Salinas Valley, and the Cambrian beds west of Salinas Valley are cut through by masses of the same rock.

\section{VOLCANIC ROCKS.}

As noted above, many of the Triassic rocks are lavas. There are, moreover, some areas of Tertiary and Pleistocene lavas; as represented on the map. Mr. Gilbert ${ }^{b}$ noted some basalt just east of Big Pine. The map of the California Hining Burean, above mentioned, shows an area of rolcanic rocks lying on the west flanks of the range in the neighborhood of Wancobi Peak, and connecting westward across Owens Valley with a larger area of lava on the eastern slopes of the Sierra. The same map also shows voleanic rocks lying on the northern slopes of the granite of White Mountain Peak, at the northern end of the range, and shows a great area of lava lying sontheast of Owens Lake, and forming the sonthern end of the range. $\mathrm{Mr}$. Turner found that the mountains east of Sandy Springs, which form a kind of connection between the northern end of the White Monntain Range and the Silver Peak Range, are mostly volcanic.

ORE DEPOSITS.

The following notes are taken from Mr. H. W. Fairbanks's writings. ${ }^{c}$ Silver-lead ores, chiefly in limestone, are found abont Cerro Gordo and southeast of Independence.

Auriferons quartz veins are abundant. They are found north of Cerro Gordo, in the Beveridge district, in the Alhambra Hills, 5 miles north of Lone Pine, between Independence and Big Pine, and east and northeast of Bishop Creek. The veins are chiefly in or near granite, often at or near the contact of it with slates or limestones. They probably have a genetic connection with the granitic intrusion.

a According to Professor Whitney, however (Geological Surrey of California, Geology, Vol. I, p. 459), the western face of the l'ange, sonth of Waucobi Peak to Bend City (just east of Camp Independence), is composed of tilted slates and other stratified rocks. If this is the case, these stratified rocks are undoubtedly continuous with the Triassic rocks south of Camp lndependence.

$b$ U.S. Geog. Sur'v. W. One Hundredth Mer., Vol. III, p. 124.

$c$ Report California Min. Bureau, 1894, p. 475; Am. Geol., Vol. XVII, No. 3, pp. 145, 146, 149, 150. 
STRUCTURE.

Mr. Gilbert ${ }^{a}$ gives a cross section of the range east of Big Pine, which exhibits several adjacent folds of moderate dip, broken by a number of faults. According to Mr. Gilbert's section the faults are not directly expressed in the topography.

Later Mr. Walcott ${ }^{b}$ described several sections of the White Mountain Range, in the same general region as that in which Mr. Gilbert's section was made. Mr. Walcott also finds the range made up of a number of adjacent folds broken by faults, and finds the chief fold to be a closely compressed syncline overthrown to the east, thus presenting a type of structure common in the Appalachians.

\section{DARWIN OR ARGUS RANGE.}

This range is low and of no great importance. It lies between the Panamint Range and the Coso Mountains and is south-southeast of the White Monntain Range. The range is about 70 miles in length and very narrow. Through its northern portion Darwin Canyon runs.

\section{SEDIMENTARY ROCKS.}

Mr. H. W. Fairbanks ${ }^{c}$ notes that the eastern face of the Argus Range, from Darwin to Modoc, is made up largely of limestone, which sometimes forms the crest of the range and is present in great thickness. Besides the limestone there is also calciferous quartzite.

The age of this Paleozoic series is not known, but it is provisionally mapped as Cambrian, in view of the probable age of the rocks of the Panamint Range to the east. $d$.

\section{IGNEOUS ROCKS.}

GRANITE.

According to Mr. Fairbauks, ${ }^{e}$ granite occupies a considerable portion of the Argus Range, forming part of a continuous body which stretches from the Mojave Desert to the Sierra Nevada. In general, it is a granular, light-colored, biotite-hornblende rock.

\section{VOLCANIC ROCKS.}

From Darwin Canyon north to the $36^{\circ} 30^{\prime}$ parallel the mountains are described as black lava hills on the topographic map of the Wheeler Survey (65-D). This same portion of the range is also represented as volcanic on the preliminary geologic map of California,

a U. S. Geog. Surv. W. One Hundredth Mer.. Vol. III, p. 34

b Am. Jour. Sci., 3d series, Vol. XLIX, 1895, p. 169

c Am. Geol., Vol. XVII, 1896, pp. 65, 149.

a Since writing the above Mr. F. B Weeks has informed the writer that in 1900 he found in Shepherd Canyon heary exposures of quartzite overlain by limestone, which he had no hesitation in referring on stratigraphic grounds to the Cambrian.

e Op. cit., p. 72 . 
issued by the California mining burean in 1891. On this map the lava is represented as extending sonthward along the range to a point beyond Malurango Peak.

Mr. H. W. Fairbanks ${ }^{a}$ reports numerous flows of andesite and basalt through the Argus Range, forming inclined plateans on the mountain slopes. One of these basalt flows is exposed in Argus Gulch, and beneath it is an ancient river channel filled with clay and gravel.

The southern portion of the range has a voleanic appearance, as seen by the writer from a point farther south.

ORE DEPOSITS.

Mr. Fairbanks ${ }^{b}$ states that a large number of gold-bearing quartz veins are scattered through the sonthern portion of the Argus Range. There is also, in the neighborhood of Darwin and Modoc, considerable galena, rich in silver, in chambers in the limestone.

\section{SLATE RANGE.}

The Slate Range lies in Panamint Valley, between the sonthern end of the Panamint and that of the Darwin or Argus ranges. It has an extent of only about 12 miles, and is combaratively low and narrow. The range derives its name from the fact that its rocks have been sheared so as to assume a slaty structure.

\section{SEDIMENTARY ROCKS.}

PALEOZOIC.

Mr. H. Wr. Fairbankss states that metamorphic strata appear prominently in the slate Range.

\section{TERTIARY.}

At the extreme southern end of the range schistose volcanics are overlain by cream-colored Tertiary sediments, capped by later basaltic lara. These Tertiary sediments are probably the same as those exposed in the Panamint Range just east of here, and also in the Funeral Mountains.

\section{IGNEOUS ROCKS.}

VOLCANIC ROCKS.

So far as could be observed, the range near IVindy Gap and from here southward to the extreme end consists of uniform rocks. As examined under the microscope, these rocks seem to be sheared feldspathic lava, much altered. The exact nature of the lava could not be determined, but it consists chiefly of a glassy groundinass, with phenocrysts of feldspar. One specimen studied was so sheared as to be comminuted into bits. 
The age of the schistose volcanics is not known, except that they are older than the basalt and probably older also than the Tertiary sediments. Their shearing suggests a considerable age and also suggests that they may be comnected with the granites of the Panamint Range, or with the ancient thyolite of that range east of Panamint, ${ }^{a}$ which rhyolite has a probable connection with that in the ricinity of Johannesburg.

At the northern end of the range the slaty rocks appear to be in part overlain by later volcanic flows, as seen from the south end. There are probably basalts similar to those at the south end of the range.

COSO RANGE.

IGNEOUS ROCKS.

GRANITE.

The central portion of the Coso Mountains is made np of granite and gneissoidal rocks. ${ }^{b}$ The rock in this range is reporter by $\mathrm{Mr}$. H. W. Fairbanks ${ }^{c}$ to be a coarse, easily decomposed granite, and the same writer states that granite makes up most of the rest of the range. ${ }^{d}$ This granite is continuous with the granite of the Sierra Nevada.

VOLCANIC ROCKS.

Mr. Gilberte riotes that the western base of Coso Range, south of Owens Lake, appear's to be entirely eruptive. Mr. Fairbanks $f$ has noted volcanic rocks belonging to two distinct periods of eruption in the western part of the range. To the older rocks belong rhyolites and andesites, while the younger consist of extensive flows of basalt (so recent in origin that their surfaces have been but slightly modified by erosion), reaching southward in long arms into Salt IVells Valley.

\section{EL PASO RANGE.}

The El Paso Range is a rugged, irregular bunch of mountains constituting an outlier of the sonthern Sierra Nevada, south of the Coso Range. The general trend of its ridges is east and west. It is bounded on the north by Salt Wells Valley and on the sonth by the Mohave Desert.

\section{SEDIMENTARY ROCKS.}

According to Mr. H. W. Fairbanks,g the stratified rocks of a metamorphic series (probably Paleozoic) form a part of the El Paso Range and are cut by the granite.

a See p. 204.

$b$ Geol. Surv. Califormia, Vol. I, p. 474.

e Report California Min. Burean, 1894, 1 474.

dAm. Geol., Vol. XVII, 1896, p. 145.

eU. S. Geog. Surv. W. One Hundredth Mer., Vol. III, p. 124.

f Am, Geol., Vol. XVII, 1896, p. 73.

$g$ Ibid., p. 65. 


\section{EARLY TERTIARIES.}

Mr. Gilbert ${ }^{a}$ has described a series of semiconsolidated beds in Redrock Canyon, in the sonthern part of the El Paso Mountains. These beds dip westward at angles ranging from $15^{\circ}$ to $30^{\circ}$ and consist of semiconsolidated sand, gravel, and volcanic tuffs interbedded with basalts and rhyolites. The gravels contain pebbles of quartz and various volcanic rocks.

Mr. II. Wr. Fairbanks ${ }^{b}$ describes the same series on the northern slope of the El Paso Range, where it also consists of elays, sandstone, volcanic tuffs, and interbedded lava sheets. The whole thickness is estimated to be 1,000 feet or more, and the series extends over a considerable area between the El Paso Range and the Sierra Nevada. Between clay strata, apparently below the tuffs, southeast of Black Mountain, a seam of coal 14 inches thick occurs in this series. In the clay above the coal leaf impressions were found, which Dr. F. H. Knowlton considered as probably belonging to the Eocene. Mr. Fairbanks notes that andesite appears as flows between the beds as well as in dikes cutting them and as sheets capping them.

The series of semiconsolidated, tilted tuff's, sands, gravels, and rolcanic sheets is evidently identical with that which constitutes the Funeral Range and the sonthern end of the Panamint Range, as described. As has already been stated, these latter beds are believed to be the same as those still farther north, in the neighborhood of Silver Peak.

\section{IGNEOUS ROCKS.}

GRANITE.

Mr. Gilbert ${ }^{c}$ notes that the El Paso Mountains have a core of granite. The same is noted by Mr. Fairbanks. ${ }^{d}$

VOLCANIC ROCKS.

Mr. Fairbanks ${ }^{e}$ notes that quartz-porphyries appear for several miles along the El Paso Range. The writer found that near Johannesburg and Randsburg, which lie among low hills just east of El Paso Range, the principal rock is an ancient sheared rhyolite. To one looking from this point westward this same rhyolite appears to form a considerable portion of the eastern end of this range also. It is possible that this is the same rock that $\mathrm{Mr}$. Fairbanks describes as quartz-porphyry. It is the most ancient volcanic rock found in the region, and is probably nearly contemporaneous with the schistose volcanics described at the southern end of the Slate Range. It

$a$ U. S. Geog. Surs. W. One Hundredth Mer., Vol. III, p. 14:.

$b$ Notes on the Geology of Eastern California: Am. Geol., Tol. XVII, 1596, p. 6i.

s Op. cit., p. 124.

d Am. Geol., Vol. XVII, 1896, pp. 65, $15 \%$.

e Ibid., p. 152. 
underlies the early Tertiary sediments. Mr. Gilbert ${ }^{a}$ notes that at the eastern end of the El Paso Mountains there is a large mountain of acide lavas, inclosing and nearly eoncealing a core of granite.

Mr. Gilbert also notes that the El Paso Mountains are flanked to the south by basaltic and trachytic rocks. Mr. Fairbanks ${ }^{b}$ describes andesites as occurring freely in this range. The trachytes described by Mr. Gilbert are probably the andesites of Mr. Fairbanks, since trachytes, as now understood, are very rare in this region.

\section{STRUCTURE.}

Reasoning from the tilting of the early Tertiary sediments, Mr. Fairbanks has inferred three distinct movements of Black Mountain in the El Paso Range. As the result of these movements, the Tertiary beds have been elevated, tilted, and extensively eroded.

\section{ORE DEPOSITS.}

According to Mr. Fairbanks, ${ }^{c}$ the granite of the El Paso Range has been in different places mineralized, and contains a small anount of gold.

\section{THE HILLS FROM RANDSBURG EAST TO PILOT KNOB.}

Forming a sort of continuation of the El Paso Range to the east is a series of low, detached, rounded, or level-topped buttes, connected by low ridges or Pleistocene detrital slopes, or entirely separated by an undulating detritus-covered desert. These hills have a general east-west trend.

\section{SEDIMENTARY ROCKS.}

ARKOSES.

On the north slopes of Malapai Mountain, about 4 or 5 miles northeast of Johannesburg, the hornblende-pyroxene-alentite, which makes up the higher portion of the monntain, is underlain by banded or bedded rocks, which at first have the aspect of altered rolcanics, but which, when examined microseopically, turn out to be arkoses of different degrees of coarseness. Most of them are granitie, while some appear to be in part derived from rhyolite. These arkoses probably overlie the ancient rhyolites. They are firmly consolidated, and they may belong to the series of Eocene sediments found near here, especially in the El Paso Range to the west, and on the east in the Leach Point Mountains.

On Pilot Knob, according to Mr. Gilbert, ${ }^{d}$ are exposed about 2,000 feet of voleanic products, probably tuffs, overlain by basaltic lava. These lie npon the granite, which is the base of the knob. 
IGNEOUS ROCKS.

The lower portion of Pilot Knoh is of siliceous biotite-granite. To the sonth, southeast, and west this same body of granite extends for miles. Many of the numerous small hils, which emerge from the general platean level of the desert area of granite, are often capped by patches of basic lava or stratified Tertiary sediments.

All the hills in the vicinity of Randsburg and Johannesburg consist of ancient sheared rhyolites, often considerably decomposed. When fresh, the rock appears to be a biotite-rhyolite, but as often as not the biotite has completely disappeared on account of decomposition, and the other minerals, notably orthoclase, have also become considerably altered. It is in this rock that the gold-bearing veins of the district occur, and the rhyolite has been locally altered at the time of the introduction of the ores so as to become a semijasperoid, and sometimes even passes into vein quartz by a process which appears to be chiefly replacement.

This ancient sheared rhyolite resembles the shearerl volcanics of the southern enrl of the Slate Range.

The greater portion of Malapai Mountain is made up of a considerable thickness of lava, which overlies the rhyolite and underlies basalt. Its intermediate age is also at once evident from its appearance. A number of specimens of this rock have been studied and show it to be probably a hornblende-pyroxene-biotite-aleutite. This rock has no apparent banding, and has a great variety of texture exposed by the erosion which it has nndergone.

The basaltic rock which caps Pilot Knob was also encomtered just west of this mountain. The specimen taken here proves to be a pyroxene-basalt, evidently belonging to the same general series as the olivine-basalt of the region. In the Browns Peak region, in the southern end of the Panamint Range, the same basalt occurs in a number of buttes, capping other rocks.

At Johamnesburg a dike of pyroxene-olivine-diabase-porphyry was found, cutting the ancient rhyolites. This dike is probably to be correlated with the basaltic flows.

The succession of igneous rocks in this district, therefore, is, so far as made out, biotite-granite, biotite-rhyolite, hornblende-pyroxenebiotite-aleutite, pyroxene-basalt, and pyroxene-olivine-diabase-porphyry.

ORE DEPOSITS.

Gold-bearing veins are very numerous in the ancient rhyolite in the vicinity of Johannesburg and Randsburg. The veins generally consist of a central thin seam of quartz, flanked above and below by sheared, silicified, and discolored country rock, which also may carry quartz nodules or segregations. There are also larger veins of clearer bluish quartz. Certain portions of these quartz veins and altered 
sheared zoues carry free gold in such quantities as to make them highgrade ores. The schistosity of the rocks has a general northeast dip of $15^{\circ}$ and $20^{\circ}$, and the veins are usually conformable to this.

\section{SIERRA NEVADA.}

Properly speaking, the Sierra Nevada does not constitute part of the present study. It was thought best, however, to include the eastern edge of this important mountain chain so as to show its relations to the region lying east of it. For the sake of uniformity a few brief descriptive notes will be given. The region is, geologically, a complicated one, but has been the subject of a great amount of careful study by many geologists, while the Basin region has been left almost untouched.

As a topographic feature the Sierra Nevada is a broad range, attaining considerable elevation and having many well-defined peaks. Its eastern face constitutes a sharp western limit to the interior Basin region, which is characterized by narrow ridges of generally less height, with flat desert valleys between. Unlike the Basin ranges, the Sierra Nevada is well watered and wooded, and from this circumstance has derived a different minor topography from that of the Basin ranges.

\section{SEDIMENTARY ROCKS.}

Mr. Turner ${ }^{a}$ states that it is probable that there are in the Sierra Nevada formations ranging in age from Archean or Algonkian to Recent. The rocks have been strongly affected by compression of the crust, which has produced close folding and schistosity, and has frequently obliterated the original nature and age of the sediments. In different parts of the range, ${ }^{b}$ however, the great series of auriferous slates has been found to contain Silurian, Carboniferous, Triassic, and Jurassic fossils. The superjacent series of less altered rocks consists of strata ranging from the Upper Cretaceous through the Tertiary. Large portions of the range are covered with auriferous river gravels of Neocene age.

Within the area represented by the map accompanying this bulletin the stratified rocks occupy only restricted areas, surrounded by great masses of granite.

CAMBRIAN.

Just west of Mono Lake there is a consilerable patch of quartzites and schists, mapped by Mr. Turner ${ }^{c}$ as Paleozoic. Mr. Walcott ${ }^{d}$ subsequently visited these rocks, and considers them identical with the Cambrian series of the White Momntains. Southward from here a

a Serenteenth Ann. Rept. U. S. Geol. Survey, Pt. I, p. 531.

$b$ H. W. Turner: Fourteenth Ann. Rept. U. S. Geol. Survey, Pt. II, p. 445.

c Seventeenth Ann. Rept. U. S. Geol. Survey, Pt. I, Pl. XVIII.

aPer'sonal communication to the writer. 
short distance, on the North Fork of San .Joaquin River, is an area of similar rocks, according to Mr. Twrner. Still farther southeast, not far from Big Pine, in Owens Valley, Mr. Walcott found small patches of Cambrian, and considers that these separate occurrences may belong to a single belt.

\section{CARBONIFEROLS.}

On the extreme western edge of the map, northeast from Mariposa, is an area of Carboniferous rocks which has been studied by Mr. Turner.

TRIASSIC.

Northwest of Owens Lake, on the eastern flanks of the Sierra Nevada, is an area of Triassic beds, consisting mainly of ancient lavas and tuffs, similar to the Triassic rocks of the White Mountains on the other side of the valley.

Some distance south of here the region around Owens Peak consists of rocks similar to the Triassic formations just described. No fossils were found in this region.

Just east of Silver City, which is southeast of Lake Tahoe, Mr. Turner has mapped sereral small exposures of sedimentary rock. In his recommaissance map ${ }^{a}$ these areas are mapped as doubtful Juratrias.

\section{JURASSIC.}

A long tongue of the Jurassic rocks which occur at Mariposa comes into the map at its extreme western end.

\section{IGNEOUS ROCKS.}

The Sierra Nevada contains enormous quantities of igneous rocks, both coarse and fine grained, and both surface flows and plutonic and dike masses. According to Mr. Turner, ${ }^{b}$ the coarse-grained rocks consist mostly of granite and granodiorite, with diorite, gabbro, etc., while the abundant Tertiary lavas consist of andesite, rhyolite, and basalt.

In the area covered by the map accompanying this bulletin (Pl. I) the greater part of the Sierras consist of coarse, granular, igneous rocks, among which granite and granitic rocks occupy the chief place.

Overlying the ancient granites, within the limit of this map, come occasional areas of Tertiary lavas. Mr. Turner has kindly supplied the writer with notes concerning two of these regions, one of which is in the neighborhood of Silver City and the other at the extreme southern end of the range, just north of the cut of the Southern Pacific Railway, between Tehachapi and MIojave. At the first-named locality Mr. Turner observed at one point a thickness of half a mile of 
voleanie lavas and tnffs. The lavas ocenpy several separated areas, and in them ocenr the ore deposits of the region. In the second locality Tertiary lavas with Tertiary serliments make up the sonthern flanks of the range.

On the flanks of the range, about Fish Springs, are flows of basalt, described by Mr. W. A. Goodyear. ${ }^{a}$ Mr. H. W. Fairbanks ${ }^{b}$ suggests that these may be of the same age as the basalts of the Coso Range. According to Mr. Fairbanks, also, "andesite covers a great stretch of country abont the head of Owens River, forming the crest of the Sierra Nevada between it and the head of the North Fork of the San Joaquin River."

\section{STRUCTURE.}

It has been recognized, from the evidence which the Mesozoic strata of the Sierra Nevada offer, that the folding of the range was initiated at the close of Jurassic time, after the Mariposa beds were deposited. ${ }^{c}$ During the period which succeeded this Jurassic movement erosion produced great changes, and gradually brought about the formation of a topography of little relief, the mountains being low, the valleys broad, and the streams sluggish. This period appears to have reached its maximum during the Miocene. ${ }^{d}$ Subsequent to the development of this style of topography there was a general disturbance which brought about the acceleration of the streams and the cutting of deep valleys, leaving high ridges between. This disturbance apparently consisted in part of differential movement, but there are evidences that the whole mass of the Sierra was uplifted at least 4,000 feet, and possibly as much as 7,000 feet.e Mr. Turner ${ }^{f}$ concludes, from the fact that the Neocene Gnlf deposits, at the very west edge of the range, have been elevated at least 1,000 feet above their original position, that the mountains were uplifted as a whole, and not by a tilt to the westward, for in the latter case the west edge of the block so tilted wonld remain approximately at its original elevation.

During the latter part of the time that the Sierra Nevada region was being worn down, a great series of auriferous gravels was deposited by the sluggish streams. These gravels, after the uplift and the acceleration of the drainage, remained often in the highest parts of the range and in the regions between the present river valleys, especially where protected by later cappings of lava.

The eastern face of the Sierra, for a distance of sereral hundred miles, is very steep, contrasting strongly with the comparatively uniform and gentle slope on the west. The earliest observers saw in this a probable fault scarp. Mr. Clarence King ${ }^{g}$ was one of the first

a Rept. of Cal. State Mining Burean, Vol. VIII, pp. 271-27\%.

${ }^{b}$ Am. Geol., Vol. XVII, p. 73.

$\varepsilon$ H. W. Turner, Serenteenth Ann. Rept. U. S. Geol. Survey, Pt. I, p. 532.

dJ. S. Diller, Fourteenth Ann. Rept. U. S. Geol. Survey. Pt. II, p. 421.

e Ibid., p. 433.

$f$ Fourteenth Ann. Rept. U. S. Geol. Survey, Pt. II, p. 443.

$g$ U. S. Geol. Expl. Fortieth Par., Vol. I, p. 744. 
of these, and the hypothesis has been aceepted by nearly all succeeding geologists.

The observations most in favor of the existence of a fault are those of high gravels on the very smmmits of the mountains above the steep eastern scarp. Mr. Diller ${ }^{a}$ has noted, at the northern end of the range, that these gravels are displaced by a fault having about 3,000 feet vertical displacement, which extends along the eastern face of the range. Mr. Russell ${ }^{b}$ also found water-worn gravels on the top of the range to the west of Mono Lake, at an altitude of about 11,500 feet. Mr. Turner ${ }^{\circ}$ found well-rounded pebbles on the main summit of the range a few miles northwest of Tower Peak, at an elevation of over 9,000 feet. Mr. Turner observes that these gravel patches along the crest of the range undoubtedly represent remnants of Neocene river beds, now almost entirely eroded.

The writer does not know of any case where actual fanlting has been proved by displacement of rocks, mnless it is the case of the displacement of recent lavas along the crest north of Honey Lake, described by Mr. Diller. ${ }^{d}$ Even in many of the instances where river gravels have been found at the summit of the range, it is possible that some other hypothesis may be found to explain their presence, as well as that of faulting. Along most of the range the rocks of the Sierra Nevada scarp do not stop abruptly, but are found in the ranges lying next east. The eastern face of the range is not the boundary between the granites on the west and the voleanics on the east, as supposed by Russell.e In the White Mountain, Pine Nut, and other ranges lying next east of the Sierra, granitic rocks are found forming the core, and also in some of the ranges farther east, growing, however, continually lower until no longer exposed by erosion.

Mr. King $f$ considered that the fault along the eastern scarp was formed either within the Eocene or at the close of Eocene time, since it evidently existed before the formation of the Miocene Pinte Lake, which was an inclosed inland body of water and was shut off from the sea by the barrier of the Sierra. On the other hand, Mr. Dillerg considered that the fault along the easter'n scarp must have been formed very recently, in post-Tertiary time, since the Tertiary river gravels and most of the volcanies are displaced. South from the area observed by Mr. Diller, however, Mr. Lindgren ${ }^{h}$ found that the eastern slope of the range was formed before the eruption of the andesitic lavas.

\footnotetext{
a Fourteenth Ann. Rept. U. S. Geol. Survey. Pt. II, p. 43:?.

$b$ Eighth Ann. Rept. U. S. Geol. Survey, Pt. I, p. 322.

c Fourteenth Ann. Rept. U. S. Geol. Survey, Pt. II, p. 44\%.

$a$ Eighth Ann. Rept. U. S. Geol. Survey, Pt. I, p. 4:9.

e Eighth Ann. Rept. U. S. Geol. Survey Pt. I, p. 371.

$f$ U.S. Geol. Expi. Fortieth Par., Vol I, p. 744

$g$ Fourteenth Ann. Rept. U.S. Geol. Survey, Pt. II, p. 432.

$h$ Bull. Geol. Soc. Am., Vol. IV, pp. 257-298.
} 
Since writing the above the writer has obtained the following additional information:

On the east front of the Sierra, between Carson and Markleeville, Mr. Lindgren has found evidence of recent faulting along the base of the monntains. Near Genoa, Pleistocene alluvial deposits are displaced some 40 feet by this fault. Another point is the behavior of the Carsun River, which, on emerging from the mountains, increases its grade abruptly, suggesting comparatively recent dislocation of its valley. Mr. Lindgren believes that the first dislocation along the eastern face of the Siema Nevada took place at the close of the Cretaceons and that movement has continued at intervals down to the present day. The faulting was not simple, but complex. A number of more or less parallel faults may be distinguished within a belt 25 miles wide. ${ }^{a}$

a Auriferous gravels of the Sierra Nevada: Jour. Geol., Vol. IV, No. 8, and oral communication to the writer. 


\section{N D EX.}

Algonkian roeks in Sierra Nevada $\quad$ Page. thambra Hills, geologic structure of ... 80 Allepaw Canyon, geologic structure of..... Alps, Austrian, resemblance of certain fossils to those of. ................ Altoona Pass, geology of ................ 89 Amargosa Range, synonym .............. 187 Amargosa Vallex, Cal., geology of.... 191, 194-195 Antelope Range, geology of . . . . . . . . . . . 37-38 Antimony, Belmont region ............... 93

Panamint Range, Cal ............... $\quad 205$

Toyabe Range..................... 97 Applegarth Canyon, geologie structure of.. $\quad 67$ Archean rocks, in Colorado Canyon ..... 133, 134

Colorado Range.................... 139

Deep Creek....................... $\quad 26$

Egan Range ....................... 47

Eldorado Range...................... $\quad 139$

Humboldt Range.................... $\quad 60$

Kern Mountains. . . . . . . . . . . . . . . . . . 26

Sierra Nevada...................... 218

Snake Range ....................... 26

Virgin Range ....................... 131-132

Area mapped......................... 16

Argus Range, Cal., geology of............ 212

Arrow Canyon Range, geology of ......... 151

Arsenic in Panamint Range, Cal .......... 205

Aubrey formation, described............... 18

occurrence of .............. 131, 133, 135, 172

A ustin, ores in region of ................. 97

Bald Mountain, geologic structure of ...... 65 situation of ........................ 77

Beaver Dam Wash, geology of region ...... 131

Belmont, geology of region .............. 90-93

Belted Range, geology of . . . . . . . . . . . . . . . 163-164

Big Pine, Cal., geology of ................ 207

Bird Spring Mountains, geology of........ 179

Black Mountains, synonym .............. 187

Bonnerille, Lake (Pleistocene), referred

to........................ 34,35

Borax, in Grapevine Range, Cal.......... 190

Boulder Canyon, geology of.............. 134 situation of $\ldots \ldots \ldots \ldots \ldots \ldots \ldots \ldots \ldots \ldots . . .136,137$

Bristol, geology of ...................... 46

Browns Peak, Cal., geology of ............ 204

Burnt Rock Mountains, Cal., geology of . 205-206

Cambrian rocks, in Candelaria Mountains. 113

Colorado Canyon................... 133

Diamond Range................... $\quad 83$

Egan Range....................... 47-48

Gold Mountain, Cal ................ 188

Graperine Range, Cal ................ 201

Highland Range .................. 41, 140
Page.

Cambrian rocks, in Humboldt Range..... $\quad 60$

Kern Mountains.................... 26-30 Kingston Range, Cal........... 196-197, 200

Las Vegas Range ...................... 155

Lone Mountain ...................... 184

Meadow Valley Range.............. 149

Panamint Range, Cal .............. 201, 202

Piñon Range ...................... is

Quinn Canyon Range ............... $\quad 69$

Schell Creek Range .................. 38-42

Silver Peak Range .................... 184

Snake Range...................... 26-30

Sierra Nevada........................ 218

Spring IIountain Range............ 165-166

Timpahute Range.................. 159

Toyabe Range....................... 94-95

White Mountain Range, Cal ......... 207

White Pine Range .................. 61

Candelaria Mountains, geology of....... 113-114

Carboniferous rocks, in Arrow Canyon

Range..................... 154

Candelaria Mountains .............. 113

Clarks Peak Mountains, Cal.......... 200

Colorado Canyon.................... 133

Diamond Range................... 81-83

Egan Range .................... 49,51-52

Funeral Range, Cal. . . . .......... 188, 189

Grant Range .................... 72

Grapevine Range, Cal . . . . . . . . . . . . . . . 188, 189

Humboldt Range.................. 60

Las Vegas Range ... . . . . . . . . . . . . . 156-157

Long Valley Range.................. 55-56

Meadow Valley Range ........... 140, 149-150

Mormon Range ................. 134-135, 140

Muddy Range..................... 137

Pahranagat Range ................... 153

Panamint Range, Cal ................ 202

Pancake Range ................... $77-78$

Piñon Range ...................... 88

Schell Creek Range ............. 39, 40, 43-44

Sierra Nevada ..................... 218, 219

Snake Range....................... 31-34

south of Spring Mountain............ 180, 181

Spring Mountain Range ............ 165-173

Toyabe Range..................... 94,95

Virgin Range ................... 131-132

White Mountain Range, Cal.......... 208

White Pine Range.................. 63-65 See also Mississippian; Paleozoic.

Carson, geology of region ................. 124

Carson River, geology of valley of ......... 121

Cedar Range, geology of ................ 36-37

Charleston Peak and Canyon, geology of .. 167 
Cherry Creek, dikes near .............. Page. geology of ...................... t9 geologie strneture near.............. 7t

Chihuahua Canyon, geology of .......... 82

Chokup Pass, geology of ................ 82-84

Chuar formation, described ............. 18, 19 occurrence of ....................... 133

Clarks Peak Hountains, Cal., geology of... 200

Cloverdale, topography of .............. 94 Clover Valley Ifountains, geology of ...... 36-37

Coal Burners Mountain, geologic structure situation of of ......................... 65

Coal, El Paso Range, Cal ................. impure, in Pancake Range........... 81 Muddy Creek....................... 137 Colorado Platean, geology ot........... 172, 173 Colorado Range, geology of ............ 138-139 Colorado River, geology of canyon and valley ....................... 131-13t Comstock lode, situation of ............ 129 Copper, Austin region................... 97

Belmont region .................... 98

Ellsworth region .................. 108

Excelsior Range ................... 113

Mineral City . . . . . . . . . . . . . . . . . . . 54

Opal or Clarks Peak Mountains, Cal.... 200

Panamint Range, Cal ............... 205 Coso Range, Cal., geology of.............. 214 Cottonwood Spring, geology of ........... 168,

Cretaceous. See also Mesozoic.

Cretaceons, Upper, rocks in Sierra Nevada. 218 Dalzell Canyon, geology of......... 118, 119, 126 Darwin Range, Cal., geology of.......... 212 Dayton, geology of region............... 120-124 Death Valley, topography and geology of.. 187, $190,191,193,194,201-203$

Deep Creek Mountains, geology of ........ 29 Deep Creek Valley, geology of ........... 34 Delamar, geology of region .............. $\quad 149$ Desert Creek, geology of region......... 127,128 Desert Mountains, geology of . . . . . . . . . . . 106 Desert Range, geology of.............. 160-161 Desatoya Range, geology of............. 102 Devonian rocks, in Antelope Range ...... $\quad 37$ Clarks Peak Mountains, Cal .......... $\quad 200$ Colorado Canyon................... 133 Desert Range....................... 161

Diamond Range ................... 82

Egan Range...................... 49-51

Funeral Range, Cal ................ 188

Golden Gate Range ................. 58

Grant Range ..................... 71-72

Grapevine Range, Cal............. 188

Hiko Range ........................ 152

Humboldt Range .................... 60

Kingston Range, Cal............... 197-198

Las Vegas Range.................. $\quad 156$

Long Valley Range ................. 56

Pahranagat Range ................. 153

Pahroc Range..................... 152

Pancake Range ................... 78

Piñon Range ..................... 88

Quinn Canyon Range ............... 71-72

Schell Creek Range ............... 11,43
Page.

Devonian rocks, in Toyabe Range......... $\quad 95$

Wahweah Range................... 90

White Pine Range.................. 63

Sce also Paleozoic.

Diamond Peak, geologic structure of ..... 83

Diamond Peak quartzite, described........ 18

Diamond Range, geology of ............. \& s1-81

Dikes. Sec also Igneous rocks.

Dikes, in Egan Range................... 53

Ellsworth Range ................... 102

Highland Range ................... 44

Schell Creek Range .................. $\quad 35$

Snake Range ...................... $\quad 35$

Toquima Range .................... 92

Dome, The, geologic structure of ......... 97

Downieville, geology of region...... 100, 102, 103

Dutton, C. E., cited ..................... 131

Egan Range, geology of ................. 47-54

Eldorado Canyon, geology of........... 121, 123

Eldorado Range, geology of.............. 139

Ellsworth Range, geology of ............ 99-103

El Paso Range, Cal., geology of......... 214-216

Ely, topography of ..................... $\quad 47$

Ely Range, geology of ................. 42

Emmons, S. F., cited .................... 101

Eorene rocks, in Burnt Rock Mountains, Cal . $\quad 206$

Excelsior Range.................. 111

Leach Point Mountains, Cal .......... 206 See also Tertiary.

Esmeralda formation, described .......... 19

occurrence of........ 106, 111, 112, 114, 199, 202

Eureka, geology of district .............. 84

Eureka quartzite, described............. 19 occurrence of .............. 31, 32, 49, 86, 202

Excelsior Flat, geology of ............... 110

Excelsior Range, geology of........... 109-113

Faulting. Sce Structure, geologic.

Fault, scissors, defined ................. 153

Folding. Sec Structure, geologic.

Fossil Butte, geology of ................ 152

Fossils, Cambrian, of White Mountain Range, great age of .......... 207

Fossils, Cambrian, list of, Egan Range.... 48

list of, Snake Range................. 31

occurrence of, Desert Range .......... 161

Grapevine Range, Cal............ 201

Kingston Range, Cal ............. 197

Las Vegas Range . .............. 155, 156

Schell Creek Range ............. 39,41,42

Silver Peak Range ............. 181, 185

Spring Mountain Range .......... 165

Timpahute Range ............... $\quad 159$

White Mountain Range, Cal ...... 207

Fossils, Carboniferous, list of, Grant Range. $\quad 72$

list of, Humboldt Range, near Fremont

Pass ....................... 60

Schell Creek Range .............. 44-45

White Mountain Range, Cal ....... 208

occurrence of, Candelaria Mountains... 114

Cottonwood Canyon, Cal.......... 202

Desert Range.................. 161

Highland Range ................. 45

Las Vegas Range ................ 157

Schell Creek Range .............. $\quad 39$

Snake Range .................... 28, 29

Toyabe Range................. 94,95 
Fossils, Carboniferous, Lower, list of, Egan

Range

Page.

Fossils, Carboniferous, Upper, list of, Diamond Range ..................

list of, Egan Range................. 51

Long Valley Range .............. 55-56

Meadow Valley Canyon............ 134

Ileadow Valley Range .......... 149, 150

Pancake Range ................. is

Snake Range .................... 32, 33

south of Spring Mountain........ 180

White Pine Range............... 63-64

occurrence of, Las Vegas Range..... 156, 157

Pleasant Valley (near)........... 33

Snake Range................ 29,32, 33

Spring IIountain Range..... 167, 170-172

Fossils, Cretaceous, Excelsior Range ....... 109

Fossils, Devonian, list of, Diamond Range..

list of, Egan Range.................

Golden Gate Range...............

Highland Range ................ .

Kingston Range, Cal .............

oceurrence of, Desert Range...........

Las Vegas Range.

Prramid Peak, Cal ................

Quinn Canyon Range, or Grant Range.............

Fossils, Eocene, occurrence of, El Paso Range, Cal .

occurrence of, Monte Cristo Jountains.

Fossils, fresh water, occurrence of, Monte Cristo Mountains. $105-106$

Fossils, Jurassic, occurrence of, Muddy Creek.

occurrence of, Spring Mountain Range.

Fossils, Miocene, occurrence of, Monte Cristo Mountains ..............

Fossils, Ordovician, list of, Golden Gate Range .....................

list of, Grant Rauge

Hot Creek .....................

Humboldt Range................

Quinn Canyon Range .............

Schell Creek Range .............. 42, 4

Snake Range .................. 30,31,33

occurrence of, Antelope Range ....... 37

Desert Range................. 160, 161

Las Vegas Range ................. 156

Snake Range...................

Ty bo ........................... 86

White Pine Range, near Hamilton . 63

Fossils, Permian, list of, Harnels Peak, Egan Range.................. 52 occurrence of, Spring Mountain Range. 171,

Fossils, Silurian. Seealso Fossils, Ordorician. Fossils, Silurian, list of, Hot Creek Range..

list of, Quinu Canyon Range and Grant

Range .........................

occurrence of, Fossil Butte............

Grapevine Peak, Cal .............

Pahranagat Range...............

Panamint Range, Cal .............

Toyabe Range.

Bull. $208-03-15$
Fossils, Silurian, occurrence of, White Mountain Range, Cal ..........

Fossils, Tertiary, occurrence of. Excelsior Range.................. 109 occurrence of, Monte Cristo Mountains. 106

Fossils, Triassic, occurrence of, Good Spring. $17 t$ occurrence of, White Mountain Range,

Cal ..................... 208,209

Pine Nut Range.............. 123

Funeral Range, Cal., geology of ........ 187-194 Gabbs Valley Range, geology of ........ 107-109 Geologic section. See Section, geologic.

Geologic structure. Sre Structure, geologie. Gold, Cherry Creek ....................

Darwin or Argus Range, Cal.......... 213

El Paso Range, Cal................ 216 Johannesburg and Rand-burg region,

Cal ...................... 217-218

Keystone Mine................... 174

Mineral City, Nev.................. 54

Osceola, Nev ...................... 36

Postoffice Springs, Cal.............. '205

Sierra Nevada region................. 220

Silver Peak Range................... 186

Spring Mountain Range.............. 174

White Mountain Range, Cal .......... 211

Golden Gate Range, geology of ..... 57-59, 74,75

Gold Mountain, Cal., geology of......... 187

Good Spring, geology of ......... 171, 174, 178, 179

Grand Canyon of the Colorado, geology

of .............. 133-134, 172, 173

Grand Canyon group, described .......... 18, 19

Grand Wash, geology of ............... 131, 132

Grant Range, geology of ............... $68-76$

sketch sections of .................. 74,75

Graperine Range, Cal., geology of... 187-194, 201

Hackberry Canyon, geology of ....... 141, 14t, 147

Hamburg limestone and shale, deseribed.. 19

occurrence of ..................... . $\quad 63$

Hamels Peak, fossils from.............. 52

Hamilton, ores in region of .............. 68

Hawthorne, geology of region............ 115

Highland Range, geology of .............. 35 -17

Hiko Range, geological structure of ....... 75 geology of ..................... 152-153

Hot Creek Canyon, geology of ............ $\quad 87$

Hot Creek Range, geology of............ 84-88

Humboldt formation, describer............ 19 occurrence of ..................... 78

Humboldt Range, geology of . ........... 59-61

Igneous rocks, in Antelope liange ....... . 3i-35 Burnt Rock Mountains. . ............ 206 Candelaria Mountains............... 114 Coso Range, Cal..................... 214 Darwin or Argus liange, Cal .......... 212 Desert Mountairs .................. 106 Diamond Range.................. 83-84 Egan Range...................... 52-53 Ellsworth Range ................... 102 El Paso Range, Cal ................. 215 Excelsior Range................... 112 Funeral Range ....... .............. 192 Gabbs Vallex ...................... 108 Golden Gate Range.................. 58 Grant Range........................ 73 Grapevine Pange, Cal .............. 192 
Igneous rocks, in Hiko Range.......... 152

Hot Creek Range.......... . . . . . . . . . 87

If umboldt Range. . . . . . . . . . . . . . . . . . . 61

Kawich Range ...................... 181

Kingston Range, Cal . . . . . . . . . . . . . 199

Leach Point Mountains, Ca].......... 206

Lone Mountain . . . . . . . . . . . . . . . . . . . 1 1 1

Long Valley Rangc.................. . 56

Meadow Valley Canyon ............ 141, 147

Meadow Valley Range................ 150

Monte Cristo Mountains... . . . . . . . . . 106

Monitor Range ................... . 89

Mormon Range. . . . . . . . . . . . . . . . . 135

Muddy Range ........ . . . . . . . . . . 137, 138

Pahranagat Range................... 154

Pahroc Range.................... 151

Panamint Range, Cal.............. 20. 201-204

l'ancake Range................... . . 79

Pilot Mountains................... 105

Pilot Knob to Randsburg, Cal........ 217

Pine Nut Range . . . . . . . . . . . . . . . . . . 120-122

Piñon Range ...................... 88

Quinn Canyon Range ............. 72-73

Ralston Desert.................. 182-183

Reese River Range ... . . . . . . . . . . . . . . . 99

Reveille Range . .................... 163

Schell Creek Range................. 44

Sierra Nevada ....................... 219

Silver Peak Range.................. $1 \$ 0$

Slate Range, Cal... . . . . . . . . . . . . . 213-214

Smith Valley Range ................ 118

Snake Range ..................... $\quad 35$

Spring Monntain Range........... . 171-175

Sweetwater Range .............. 126-128

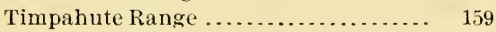

Toquima Range ................ 92

Toyabe Range . . . . . . . . . . . . . . . . . . 95-96

Virgin Range .................... . 131, 132

Virginia Range ................. 129-130

Wahweah Range................... 90

White Mountain Range, Cal .... 208, 210-211

Walker River Range ........ . . . . . 115-116

White Pine Range................... 65

Worthington Mountains . ........... 76

Indian Spring, geology of region... . 165-167,180

Ione, geology of region . . . . . . . . . . . . . . . . . 99

Iron, Austin region

Belmont region..

Jeff Davis Peak. See Whecler Peak.

Jurassic rocks, in Pilot Mountains ........ 104

Sierra Nevada................... . . 218, 219

- Epring Mountain Range .... 169-171, 173, 174 See also Mesozoic.

Kawich Range, geology of . ............. 181

Kern Mountains, geology of ....... 26, 29, 35, 36 topographic situation of ............ 25

King, clarence, eited. . . . . . . . . . . . . . . . 101

Kingston Range, Cal., geology of ....... 195-200

Koipato formation, described ............ 19 occurrence of .................... 101, 209

Lake Bonnevilje (PJeistocene).......... 34, 35 Lake Lahontan (Pleistocene), traces of ... 116-

Lake Mono, former height of 210

Lake Shoshone (Pliocene), sediments of, in Soda Springs Valley ......... sediments of, in Silver Peak Range...
Lake Shoshone (Pliocene), sediments of, in White Mountain Range....... 209 extent of .............. ........ 209-210

Lake, former, in Ralston Desert......... 183 near Sweetwater Range... . . . . . . . . 128, 129

Lake, Pleistocene, in Gabbs Valley ...... 107.108 Grapevine and Funeral ranges, Cal. . 191, 194 Ralston Desert ..................... 183 Little Smoky and White Pine valleys. . 79

Lake, Pliocene, in vicinity of Carson ... 124, 125 Meadow Valley...................... 148 Pancake Range :................. 72 west of Quinn Canyon Range........ 72 White Mountain Range........... 209, 210 Lake, Tertiary, in Amargosa Valley, Cal... 195 near Grapevine Range, Cal .......... 190

Las Vegas Range, geology of ........... 155

Lava. tee Igneous rocks.

Leach Point Mountains, Cal., geology of. 205-206

Lead, Austin region.................. 97 Belmont region ................... 93

Darwin or Argus Range, Cal ........ 213

Hamilton district ................ 68 Mineral City ...................... 54 Spring Mountain Range ............ 180

White Mountain Range, Cal ......... 211

Lone Mountain, geology of ............ 183-181

Lone Mountain limestone, described ..... 20 occurrence of .............. 31,32,37,49

Long Valley Range, geology of ......... 54-57 Manganese, black oxide of, near Hamilton. $\quad 68$ Mason Butte, geology of ............... 116 Mastodon, teeth and bones of, Las Vegas Range .................... 157 Meadow Valley Canyon, geology of ..... 131-136, 139-148

Meadow Yalley Range, geology of ........ 148 Mesozoic rocks, in Excelsior Range..... 110-111 Kingston Range, Cal.............. 198 Muddy Range....................... . . 137 Pilot Mountain ................. 103-104 Snake Range . . . . . . . . . . . . . . . . . . . 33-34 Spring Mountain Range........ I69, 17:2-174 See also Cretaceous; Jurassic; Triassic.

Mesquite Valley, Cal., geology of ....... 202,204

Mineral City, mines at .............. 54

Miocene rocks, in Excelsior Range........ 111 Scc also Tertiary:

Mississippian rocks, in Spring Mountain Range..................... 167 Sce also Carboniferous.

Mokeamoke Ridge, geology of . . . . . . . 6. 62-68

Monitor Range, geology of ............. . 89

Mono Lake, geology of region........... 218

former extent of................... 210

Monte Cristo Mountains, geology of.... . 105-106

Mormon Canyon, geology of .......... 144-145

Mormon Range, geology of . . . . . . . . . . . 13 13-136

Mountain Spring, geology of region..... 169, 177

Muddy Range, geology of ............ 136-138

Mnd Spring, geology of region ........... 160

Mule Spring, geology of region..... 170, 176,177

Neocene gravels, in Sierra Nevada....... 218

Nevada Jimestone, described............ 20 occurrence of..................... 37,83

Newark Mountain, geologic structure of ... $\quad 80$ 
Jinge.

Niagara formation, oceurrence of ......... so so Ogden quartzite, described.............. 20 Opal vountains, Cal., geology of......... 200 Ophir Canyon, geologie strueture of ....... 96 Ordovician rocks, in Antelope Range'..... 37

Desert Range..................... . 160, 161 Golden Gate Range ................ 5s Grant Range ................... $70-71$

Hot Creek Range. . . . . . . . . . . . . . . . 85-86

Humboldt Range.................... 61

Las Vegas Range ................... 15t

Piñon Range .................... s8

Quinn Canyon Range,............. 70-71

Snake Range ..................... . 33, 84

White Jountain Range, Cal .......... 208 see also Paleozoic; Silurian.

Ores, Ellsworth Range ................ 108

Eureka district .....................

Hot Creek Range................... 87

Reveille region.................... 163

Timpahute Range................... 160

Toyabe Range..................... 97 sce also Copper, Gold, ete.

Oseeola, geology of . . . . . . . . . . . . . . . $27-30$

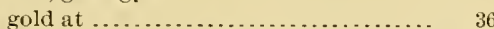

Owens Lake, Cal., geology of region .. 210, 211, 219 Pahranagat Range, geology of . . ....... 153-151

Pahroc Range, geology of . . . . . . . . . . . . 151-152

Pah-Ute Lake, use of name............. $\quad 22$

Painted Nesa, geology of ............... 117

Paleozoic rocks, in Darwin or Argus Range, Cal .

212

El Paso Range, Cal.................. 214

Meadow Valley Canyon......... 140, 143, 145

Meadow Valley Range............... 150

Mnddy Range..................... 137

Panamint Range, Cal .............. 201

Reveille Range.................... 162

Slate Range, Cal................... 213

Sce also Carboniferous; Devonian; Ordorician; Permian; Silurian.

Panaca, geology of region............... 143 Panamint Range, Cal., geology of. . . . . . . 200-205 Pancake Range, geology of ............ $77-81$ Patterson, geology of .................. 40 Pennsylvanian rocks in Spring Ilountain Range ................... 167,172

Permian roeks, in spring Mountain Range. 171, See also Paleozoie.

Pilot Knob, Cal., geology of . . . . . . . . . . 216-218 Pilot YIountains, geology of ............ 103-105 Pine Nut Range, geology of ........... 120-125

Piñon Range, geology of ................. 88-90

Pioche, geology of region .............. 41, 42 geologic strueture at ............... 46

Pleasant Valley, geology of . . . . . . . . . . 29, 33-35 Pleistocene Lake. see Lake, P'eistocene; Lake Bonneville; Lake Lahontan.

Pleistocene rocks, in Funeral Range, (al. . Gabbs Valley ... . . . . . . . . . . . . . . . . Golden Gate Range ................ Grant Range

Grapevine Range, Cal............... Las Vegas Range
Pleistorene rocks, in Meadow Va:icy 1 anyon ................... 1 $1: i-147$

Panamint Range, (al . . . . . . . . . . . . 203

P’ancake Range ................. 78,79

Pine Nut Range ................... 124

Quinn Canyon Rutuge .............. 72

Ralston Desert .................... 183

Smith Valley Range.............. 11 4,119

Snake Range ...................... 34

Toquima Range .................... 91

Walker River Range .............. 116i-117

White Mountain Ringe, Cal . . . . . . . . 209

Pliorene lake. Sce Lake, Pliocene; Lake Shoshone.

Pliocene rocks, in Candelaria Mo:mtains.. 114

Excelsior Range................... 111

Grant Range .................... $7_{2}$

Humboldt Range.................... 60

Neadow Valley Canyon ............. 143-146

Meadow Valley Range ................ 150

Mlormon Range.................... $13 \tilde{}$

Pancake Range ................... 78

Pilot Mountains ................... 104-105

Pine Nut Range................. 123-125

Quinu Canyon Range ............... 72

Silver Peak Range .................. 185

Smith Valley Range .............. 11 .

Snake Range ..................... $3 !$

Sweetwater Range ................. $12 \mathrm{~S}$

Virgin Range...... . . . . . . . . . . . . . 131-132

Walker River Range .............. 117

White Mountain Range, Cal ........ 209-210 See also Tertiary.

Pogonip Mountain, geology of . . . . . . . . . . 62-68

geologic seetion of ................ 63

Pogonip formation, deseribed........... 21

accurrence of .. 40,42, 48,49,5S, $83,46,91,152,202$ Prospect Mountain limestone and $c_{1}$ :artzite, deseribed.................. 21

Quartz Peak, geology of................ 153

Quinn Canyon Range, genlogy $+f \ldots \ldots \ldots$ (is -76

sketeh section of .................. $7 t$

Railroad Pass, geologie strueturu of....... 83

Railroad Valley, geology of............. 58

Ralston Desert, geology of ........... 1;1-183 Randsburg, Cal., geology of hills east i $f$... 216 Ravens Nest, geologie strueture at....... 89

Red Wall limestone, described.......... . .21

occurrence of .............. 131, 133, 134, 172

Reese River Range, geology of ............ . 98-99

Reveille Range, geolıgy of............. 161-163 Ruby Group of Mountains, use of name.... 56 Salt, surface bed of, at Furnace Creek, Cal. 191 Saratoga Springs, Cal., geology of ........ 187 Sehellbourne, geology of............... 44,45 Schell Creek Range, geology of .......... 38-17 Scissors fault, defined................. 153 Secret Canyon shale, described ........... 22 Section, geologie, at Big Pine, Cal......... 207 Cottonwood spring .............. 16\%, 177 Diamond Range.................. 83 Good Spring..................... 171, 174 Grand Canyen and spring Mountain, correlation of............... 173

Hot Creek ....................... 85 near Indian Springs................. 167 Kingston Range, Cal .............. 196, 197 
Page.

Section, geologic, at Meadow Valley Canyon 118 Pogonip Mountain ................. 63 Quartz Peak.................... 15̃3,151 Saratoga Springs, Cal .............. 187 near Schelibourne.................. $\quad 39$ near Stampede Gap ................ 41 Timpahute Range................ 159 Virginia Range.................... 130 Shoshone, Lake (Pliocene)...... 104, 186, 209-210 Sierra Nevada, geology of.............. 218 Silurian rocks, in Antelope Range........ 37

Desert Range.................... 160-161 Diamond Range ................... 83

Egan Range ........................ 45-49

Golden Gate Range................. 57-58 Grant Range .................... 69-71

Graperine Range................... 188

Hiko Range ....................... 152

Hot Creek Range.................. 85-86

Las Yegas Range ................. 15.5, 156

Lone Jountain................... 1st

Pahranagat Range ................ 153

Pahroe Range ...................... 152

Panamint Range, Cal .............. 201,202

Piñon Range ..................... is

Quinn Canyon Range ................ c9-71

Schell Creek Range ................. 40-43

Sierra Nevada .................... 218

Silver Peak Range ................... 185

snake Range ..................... 30-32

Timpahnte Range................. 159

Toquima Range .................... 91

Toyabe Range...................... 94,95

White Mountain Range, Cal .......... 208

White Pine Range.................

Worthington Mlountains ............. $\quad 76$ See also Ordovician; Paleozoic.

Silver, in Austin region . . ................ 97

Belmont region.................... 99

Cherry Creek ...................... $5 t$

Darwin or Ang1s Range, Cal. ........ 213

Mineral City...................... 54

Opal or Clarks Peak Monntains, Cal... 200

Panamint Range, Cal................ 205

Silver Peak Range.................. 186

Spring Hountain Range............. 180

Torabe Range ..................... 97

Treasure Hill..................... 68

White Mountain Range, Cal.......... 211

Silver Peak Range, geology of ........... 181-186 Slate Range, Cal., geology of........... 204, 213 Smith Valley Range, geology of ......... 117-120

Snake Range, geology of ................. 25-36 Sodeville, geology of region............ 103,10t Spring Mountain Range, geology of ...... 161-180

sketch sections of.................. 176-179

Springs, on Snake Range.............. 25, 26

hot, on Golden Gate Range........... 5s, 59

hot, on Hot Creek Range............. st

warm, on Spring Mountain Range...... 165 Stampede Gap, geology of............. 41, 43, 46 Stanton, T. W., cited ............... 109, 110, 123 Star Peak formation, described ........... occurrence of .................... 101, 123 :Stonewall Mlountain, geology of .......... 18:
Page.

Structure, geologic, in Amargosa Valley, Cal ...................... 195

Antelope Range................... 35

Durnt Rock Mountains, Cal ........... 206

Desert Range...................... 161

Egan Range ...................... 53-54

Ellsworth Range .................. 102-103

El Paso Range, Cal ................... 216

Excelsior Range................... 112

Funeral Range, Cal ................ 192-194

Golden Gate Range................. 59

Grant Range .................... $71-76$

Grapevine Range, Cal.............. 192-194

Highland Range .................... 45-47

Hiko Range ...................... 153

Hot Creek Range................... $\quad 87$

Humboldt Range....................

hingston Range................... 199

Las Vegas Range. ................ 157-159

Leach Point Mountains, Cal .......... 206

Long Valley Range ................ 55-5i

Neadow Valley Range ............. 150-151

Mormon Range.................... 135-136

Muddy Range ..................... 138

Pahroe Range .................... 152

Panamint Range, Cal ................ 204

Pancake Range .................. 80

Piñon Range...................... 89

Quinn Canyon Range.............. $73-76$

Schell Creek Range................. 44-17

Sierra Nevada...................... $\quad 220$

Snake Range ....................... 35-56

Spring Mountain Range ........... 175-180

Timpahute Range................. 160

Toquima Range.................. 92-93

Torabe Range..................... 96

Virgin Range ...................... 13:-133

White Mountain Range, Cal ......... 212

White Pine Range ................ 65-6s

Worthington Mountains ............. 77 Subaerial accumulations, disadrantages for study .................... 139-140

in Gabbs Valley................... 108

in Long Valley Range ............... 55

in Nevada valleys, generally.......... 139

in Quinn Canyon Range and Grant Range.................... 72 Sweetwater, geology of regioll .......... 119,127 Sweetwater Range, geology of .......... 125-129 Tertiary rocks in Amargosa Valley, Cal ... 195 Candelaria Nountains ............... 114

El Paso Range ..................... 215

Excelsior Range .................. 109-111

Funeral Range, Cal ............. 1s9-191, 193 Gabbs Valley...................... 107 Grapevine Range, Cal ............. 189-191 Hot Creek Range.................... 86

Kiawich Range .................... 181

ringston Range, Cal............... 198

Las Vegas Range.................... $\quad 157$

Monte Cristo Mountains.............. 10

Muddy Range...................... 137

Panamint Range ................ 201, 202

Pancake Range ................... $75-79$

Filot Mountains................... 103-104

Ralston Desert.................... 153 
Tertiary rocks in Reveille Range........... l'age.

Silver Peak Range ................. 195

slate Ringe ....................... 213

Snake Range ..................... $33-34$

Toyabe Range...................... 95

Virgin River Valley................. 132 Sice also Eocene; Miocene; Neocene; Pliocene.

Timpahute Range, geology of $159-150$

Tonto formation, deseribed 15,22

oceurrence of .................... 133

Toquima Range, geology of ............. 89-93

Torabe Range, geology of.............. 93-97

Treasure Hill, geologic structure of ....... 66- 68

Triassie rocks. Sice also Mesozoic.

Triassic roeks in Ellsworth Range ...... 191, 192.

Muddy Range.................... 137

l'ine Nut Range . . . . . . . . . . . . . . . . . 122-123

Sierra Nevada .................. 218, 219

Spring Mountain Range ........... 172, 174

Virginia Range.................... 130

White Hountain Range, Cal . ....... 20\%-209

Truckee formation, described........... 22

Tybo, geology of ....................
Uiyabi Pass, geology of.................. 33

structure of ...................... 35

Unkar formation, deseribed........... 1s, 19, 23 oceurrence of ..................... 133

Virginia Range, geology of ............. 129-130

Virgin Range, geology of .............. 131-133

Wahweah Range, geology of ............. $89-90$

Walker River Range, geology of ..... 115-117, 118

Wasateh limestone, described............. 23

Wassuck Range. Scc Walker River Range.

Water supply, springs on Snake Range ... 25, 26

Weber conglomerate, described .......... 23

Wheeler Peak, geology of ........ 25, 27, 31, 32, 35

White Bluff Spring, geology of region...... 161

White Mountain Range, Cal., geology of. 206-212

White Pine formation, described .......... 23-24 occurrence of ................... $78,80,83$

White Pine Range, geology of ............ 61-65

White Pine Valley, situation of ........... 77

Whites Peak, geologic structure of........ 45

Wileys, geology of region ............... 127

Wind, effects of. See Subaerial aceumulations.

Worthington Mountains, geology of ...... $76-77$ 



\section{PUBLICATIONS OF UNITED STATES GEOLOGICAL SURVEY.}

[Bulletin No. 208.]

The serial publications of the United States (reological Aurvey consist of (1) Annual Reports, (2) Monographs, (3) Professional Papers, (4) Bulletins, (5) Mineral Resources, (6) Water-supply and Irrigation Papers, (7) Topographic Atlas of United States-folios and sejarate sheets thereof, (8) Geologic Atlas of United States-folios thereof. The classes numbered 2,7 , and 8 are sold at cost of publication; the others are clistributer free. A circular giving complete lists may be had on application.

The Bulletins, Professional Tapers, and Water-Supply Papers treat of a variety of subjects, and the total number issued is large. They have therefore been classified into the following series: $A$, Economic geology; B, Descriptive geology; C, Systematic geology and paleontology; D, Petrography and mineralogy; E, Chemistry and physics; F, Geography; G, Miscellaneons; H, Forestry; I, Irrigation; J, Water storage; $\mathrm{K}$, Pumping water; L, Quality of water; M, General hydrographic investigations; N, Water power; O, Underground waters; I', Hydrographic progress reports. This bulletin is the twenty-seventh number in Series B, the complete list of which follows. (PP = Professional Paper; $\mathrm{B}=$ Bulletin; $\mathrm{WS}=$ Water-Supply Paper.)

\section{SERIES B, DESCRIPTIYE GEOLOCY.}

B 23. Observations on the junction between the Eastern sindstone and the Keweenaw series on Keweenaw Point, Lake Superior, by R. D. Irving and T. C. Chamberlin. 1585. 124 pp., 17 pls.

B 33. Notes on geology of northern California, by J. S. Diller. $1856.23 \mathrm{pp.} \mathrm{(Ont} \mathrm{of} \mathrm{stock.)}$

B 39. The upper beaches and reItas of Glacial Lake Agassiz, by Warren I'pham. 18s7. 84 pp., 1 pl. (Out of stock.)

B 40. Changes in river courses in Washington Territory due to glaciation, by Bailey Willis. 1887. 10 pp., 4 pls. (Ont of stock.)

B 4. The present condition of kuowlerge of the geolngy of Texas, by R. T. Hill. 1887. 94 pp. (Out of stock.)

B 5\%3. The geology of Nantucket, by N. S. Shaler. $1 \$ \$ 9.55$ Ip., 10 pls. (Out of stock.)

B 57. A geological reconnaissance in southwesterṇ Kansas, by Robert Hay. 1890. 49 pp., 2 pls.

B 58. The glacial boundary in western Pennsylvania, Ohio, Kentucky, Indiana, and Illinois, by G. F. Wright, with introduction by T. C. Chamberlin. 1890. $112 \mathrm{pp} ., 8 \mathrm{pls.} \mathrm{(Out} \mathrm{of} \mathrm{stock.)}$

B 67. The relations of the traps of the Newark system in the New Jersey region, by N. H. Darton. 1890. $82 \mathrm{pp}$.

B 104. Glaciation of the Yellowstone Valley north of the Park, by W. H. Weed. 1893.41 pp., 4 pls.

B 105. A geological recomnaissance in central Washington, by I. C. Russell. 1893. 108 pp., 12 pls. (Out of stock.)

B 119. A geological recomaissance in northwest Wyoming, by G. H. Eldridge. 1894. 72 pp., 4 pls.

B 137. The geology of the Fort Riley Military Reservation and ricinity, Kansas, by Robert Hay. 1896. $35 \mathrm{pp} ., 8 \mathrm{pls.}$

B 14t. The moraines of the Missouri cotean and their attendant deyosit;, by J. E. Todd. 1896. 71 pp., 21 pls.

B 15s. The moraines of southeastern south Dakota and their attendant defosits, by J. E. Todd. 1899. 171 pp., 27 pls.

B 159. The geology of castern Berkshire County, Iassuchusetts, ly B. K. Emerson. 1899. 139 pp., 9 pls.

B 165. Contributions to the geology of Maine, by H. S. Williams and H. E. Gregory. 1900. 212 pp., $14 \mathrm{pls}$.

WS 70. Geology and water resources of the Patrick and Goshen Hole quadrangles in castern Wyoming and western Nebraska, by G. I. Adams. 1902. 50 pp., 11 pls.

B 199. Geology and water resources of the Snake River Plains of Idaho, by 1. c. Russell. 1902.192 pp., 25 pls. 
PP 1. Preliminary report on the Ketchikan mining district, Alaska, with an introductory sketeh of the geology of southeastern Alaska, by A. H. Brooks. $1902.120 \mathrm{pp} ., 2$ pls.

PP 2. Reconnaissance of the northwestern portion of Seward Peninsula, Alaska, by A. J. Coliier. 1902. $70 \mathrm{pp} ., 11 \mathrm{pls}$.

PP 3. Geology and petrography of Crater Lake National Park, by J. S. Diller and H. B. Patton. 1902. 167 pp., 19 pls.

PP 10. Reconnaissance from Fort Hamlin to Kotzebue Sound, Alaska, by way of Dall, Kanuti, Allen, and Kowak rivers, by W. C. Mendemhall. 1902.68 pp., 10 pls.

PP 11. Clars of the United States east of the Iississippi River, by Heinrich Ries. 1903. 298 pp., 9 pls. PP 12. Geology of the Globe copper district, Arizona, by F. L. Ransome. 1903. 168 pp., 27 pls.

PP 13. Drainage modifications in southeastern Ohio and adjacent parts of West Virginia and Kentucky, by W. G. Tight. 1903.111 pp., 17 pls.

B 208. Descriptive geology of Nevada soutl of the fortieth parallel and adjacent portions of California, by J. E. Spurr. 1903. 229 pp., 8 pls.

Correspondence should be addressed to

The Director,

United States Geological Survey, Washington, D. C.

MAY, 1903. 


\section{LIBRARY CATALOGUE SLIPS.}

[Mount each slip upon a separate card, placing the subject at the top of the second slip. The name of the series should not be repeated on the series card. but add the alditional numbers, as received, to the first entry.]

\section{Spurr, Josiah Edward.}

... Descriptive geology of Nevada south of the for-
tietl parallel and adjacent portions of California, by Josiah Edward Spurr. Washington, Gor't print. off., 1903 .

229, III p. \& pl. incl. maps, 25 fig. $23 \frac{1}{2} \mathrm{~cm}$. (U. S. Geological survey. Bulletin no. 208.)

Map in pocket.

Subject series B, Descriptive geology, 27 .

\section{Spurr, Josiah Edward.}

... Descriptive geology of Nevada south of the fortieth parallel and adjacent portions of California, by Josiah Edward Spurr. IVashington, Gov't print. off., I903.

229 , III p. 8 pl. incl. maps, 25 fig. $23 \frac{1}{2} \mathrm{~cm}$. (U. S. Geological survey. Bulletin no. 208.)

Map in pocket.

Subject series B, Descriptive geology, 27.

\section{U. S. Geological survey.}

Bulletins.

110. 20S. Spurr, J. E. Descriptive geology of Nevada south of the fortieth parallel and adjacent portions of California. I9O3.

\section{U. S. Dept. of the Interior.} see also

U. S. Geological survey.

Bull. 208-03-16 



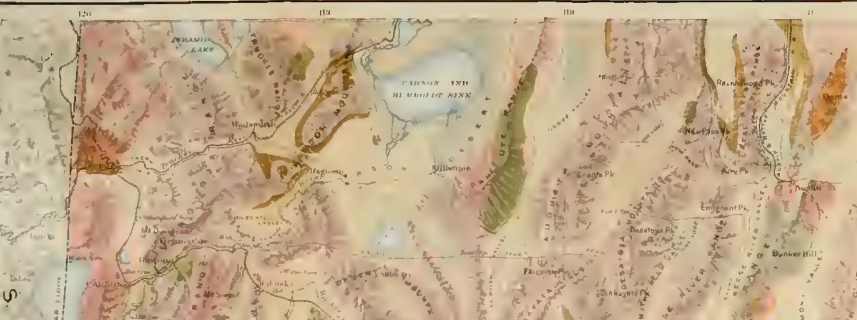

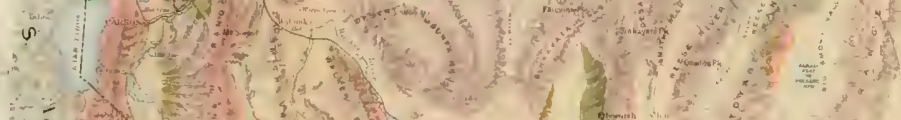

-1 at

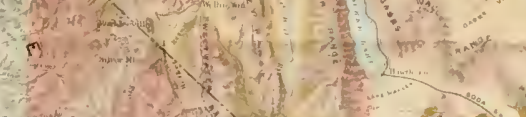
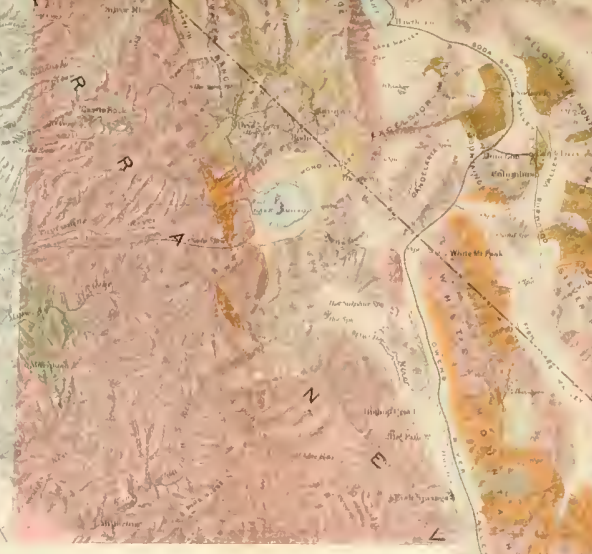

$17 \square \square \square \square \square$
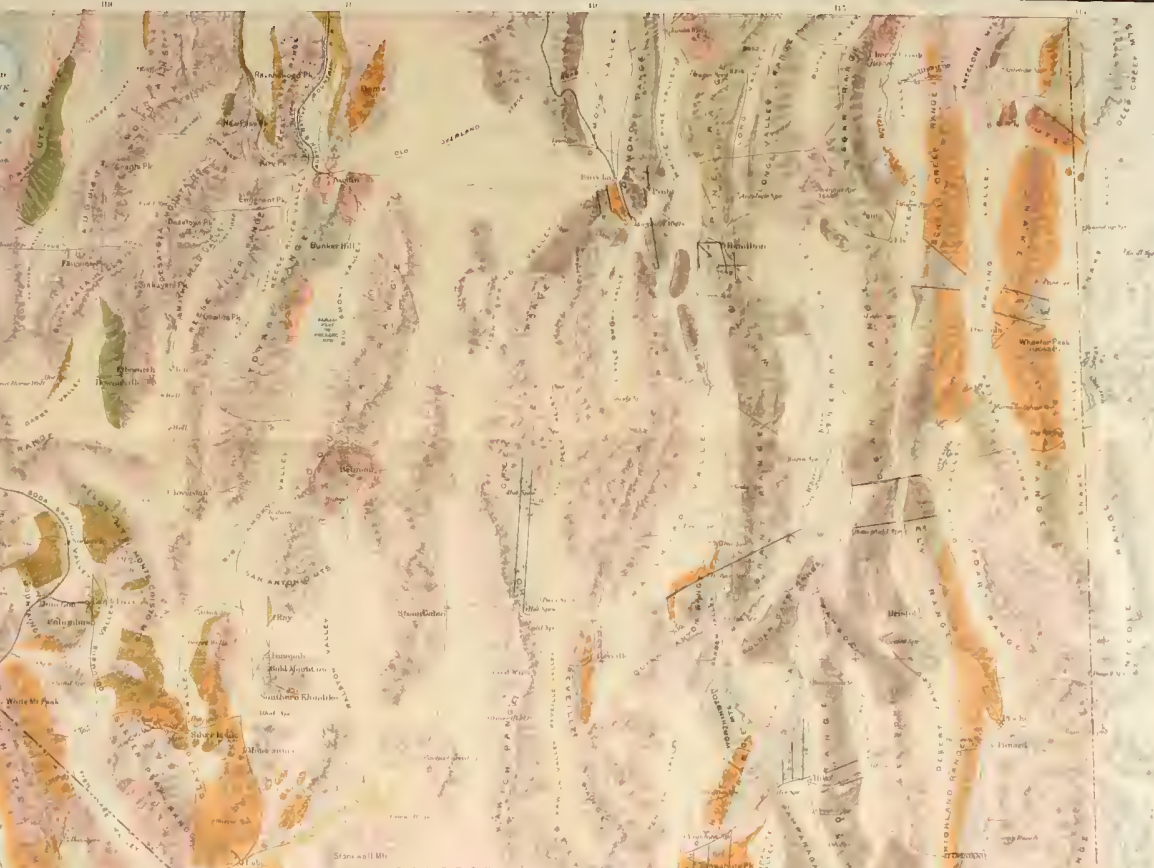

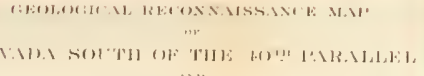

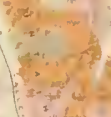

(1)

(1)

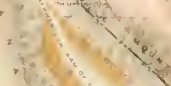

(1)

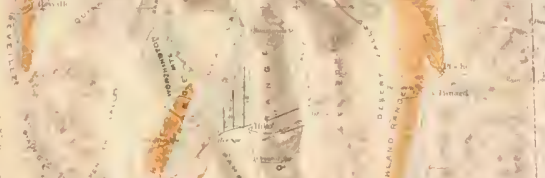

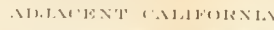

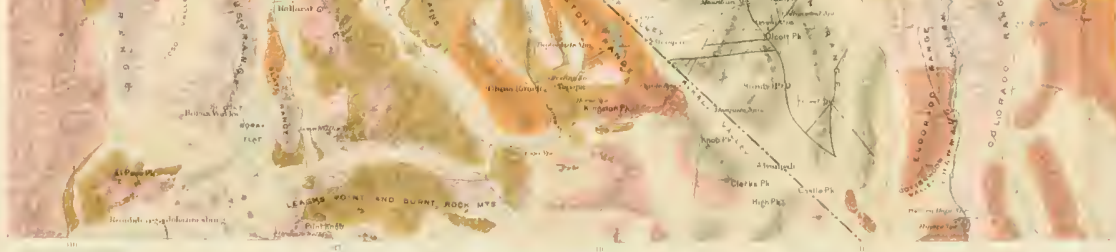

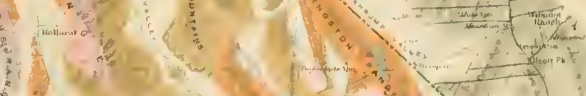






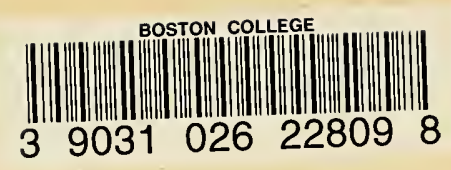


<smiles>C1CCC(C2CCCC2)C1</smiles> 


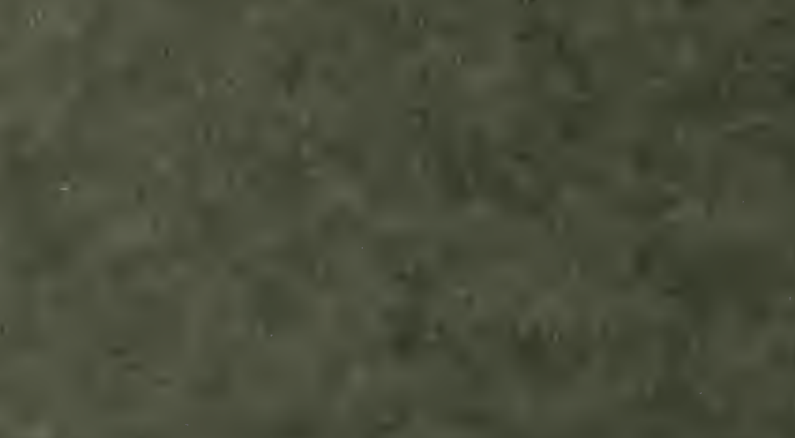

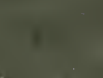

$$
2 x^{2}+2 x y
$$

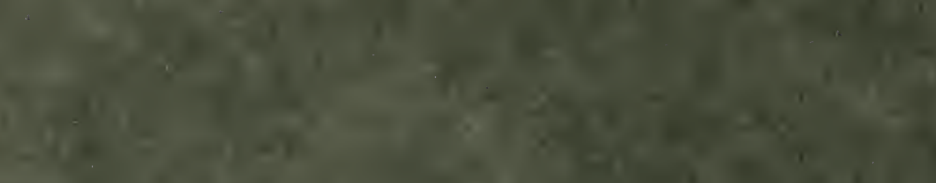

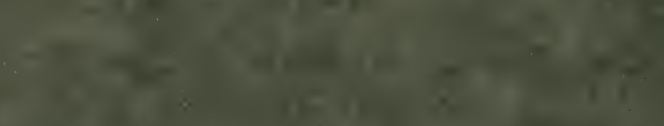

30.

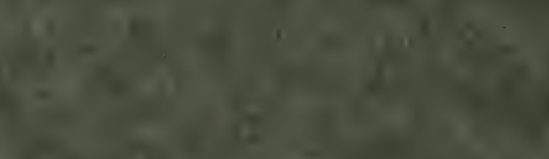

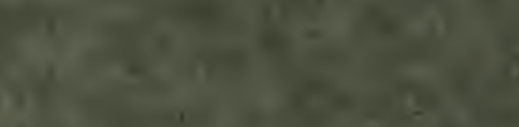

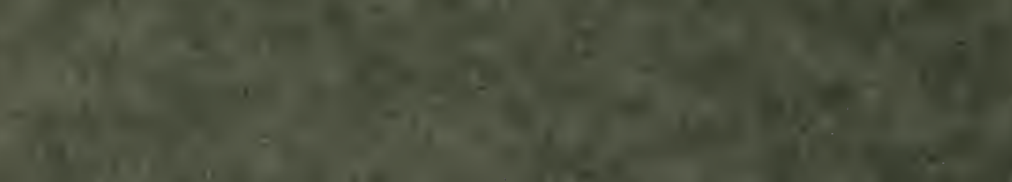

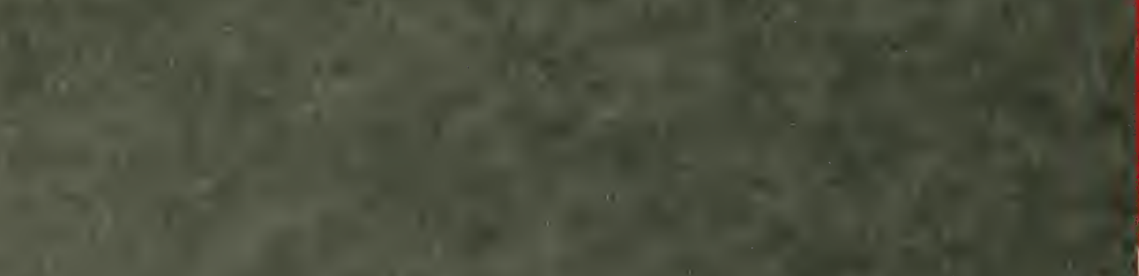

7

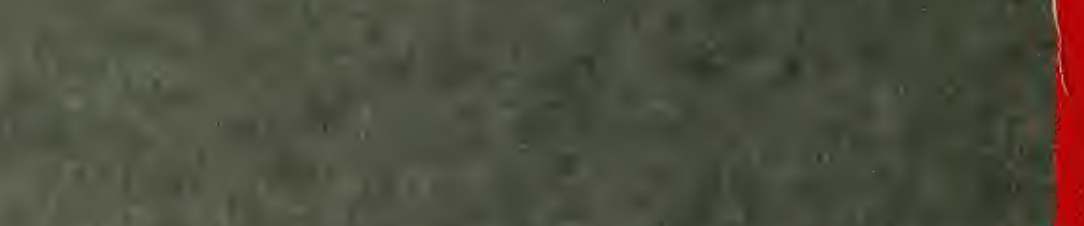

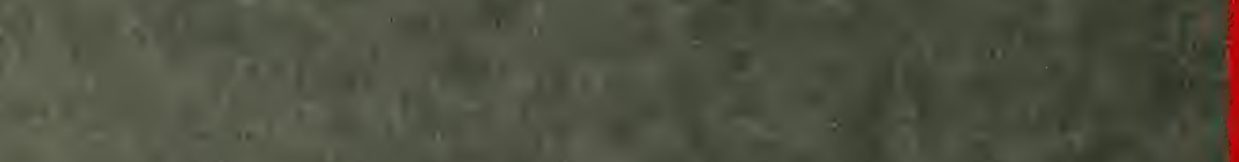

